TEXAS TECH UNIVERSITY

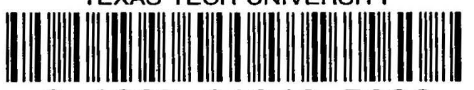

3 1295013465603 
DEPARTMENT OF THE INTERIOR

UNITED S'TATES GEOLOGICAL SURVEY

GEORGE OTIS SMITH, DIRECTOR

\section{BULLETIN 347}

\section{THE}

\section{KETCHIKAN AND WRANGELL MINING DISTRICTS, ALASKA}

BY

FRED EUGENE WRIGHT

AND

CHARLES WILL WRIGHT

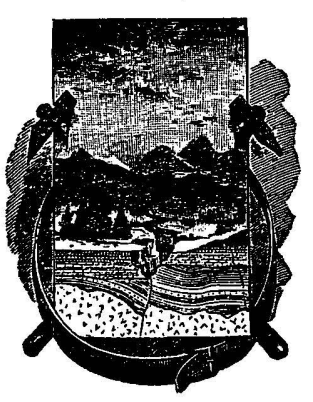

WASHINGTON

GOVERNMENT PRINTING OFFICE

1908

LIBRARY

TEWAS TFCHNOLOGIOA

LUPSOCK TEXAS 



\section{CONTENTS.}

Preface, by Alfred

Introduction

General statement 11

Field work

Maps -

Literature

History of mining developments

Ketchikan mining district__._. 16

Wrangell mining district _....... 18

Production _._..... 19

Geographic sketch of southeastern Alaska___________ 21

Geography of the Ketchikan and Wrangell districts_________ 22

General statement _-_- 22

Mainland belt _-_-_- 23

Seaward islands

Climatic conditions _...- 27

Timber and vegetation 30

Distribution of timber-_._. 30

Value of timber -

Growth of vegetation

National forest._-_-_- 32

General geology of southeastern Alaska

General statement

Stratigraphic succession:__._. 33

Rock formations

Structure -___- 38

Mineral deposits_-_-_-_-_-_-_- 41

Geology of the Ketchikan and Wrangell mining districts___-_______-_-_ 43

Geologic maps__-___-_._- 43

Sedimentary rocks__-_._- 45

General statement _.-_ 45

Paleozoic strata

Silurian _._-_.-. 45

Devonian --.--_- 46

Carboniferous -

Mesozoic strata_-_-_-_- 57

Tertiary strata

Igneous rocks___-___ 61

Coast range intrusives

General description__. 61

Average composition _-_. 63

Contact metamorphism-- 65

Dike rocks and mineralization 
Geology of the Ketchikan and Wrangell mining districts-Continued.

Page.

Igneous rocks-Continued.

Other intrusives _-_. 69

Extrusives -_._. 70

Greenstones -

Andesites -

Basalts -

Outline of geologic history

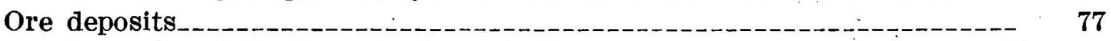

General distribution of mineralization

Coast Range intrusive belt and adjacent schists_-_-_-_ 77

Slate-greenstone belt___-_- 78

Prince of Wales Island and the seaward islands

Principal characteristics of ore deposits

General statement _._. 80

Vein deposits___. 80

Breccià veins__._- 81

Lode deposits _._.

Contact-metamorphic deposits _... 83

Character of ores_-_- 84

Copper ores _-_. 84

Gold ores _- 85

Ore minerals _-_. 85

Native minerals _-_-_-_-_-_-_- 85

Sulphides, tellurides, arsenides, etc.___._- 86

Oxides, carbonates, and silicates

Detailed descriptions of mines and prospects

General statement _._._. 93

Copper mines_-_-_-_-_-_-_- 93

General statement _.__ 93

Hetta Inlet_....... 94

General description_-_-_-_.- 94

Geology -

Ore deposits_._-_._- 95

Copper Mountain group

Jumbo group.__- 99

Green Monster group_-_- 102

Houghton group_-___- 103

Sultana group_-_-_- 104

Corbin mine_-_-_-_-_- 105

Copper City mine

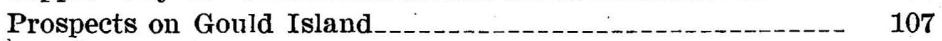

Prospects at head of Copper Harbor

Prospects on Hetta Mountain

Kasaan Peninsula___._._. 108

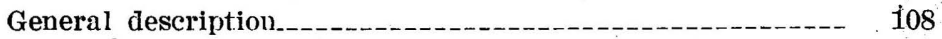

Geology -..._- 110

Ore deposits_____- 111

Mamie mine_-_-_-_-_-_-_-_-_-_-_-_- 112

Stevenstown mine

Mount Andrew mine 115

Uncle Sam mine.___. 117

Copper Queen group 
Detailed descriptions of mines and prospects-Continued.

Page.

Copper mines-Continued.

Kasaan Peninsula-Continued.

Poor Man's group.

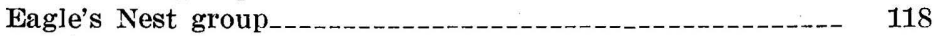

Taylor prospect__-_._-_-_- 119

Mammoth group_-_. 119

Other prospects_._-_._- 120

Karta Bay

General description

Rush \& Brown mine

Venus group__._.

Goodro claims

Tolstoi Bay__..._._. 126

General description._-_-_-_-_- 126

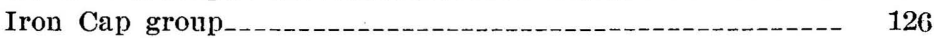

Wallace group_-

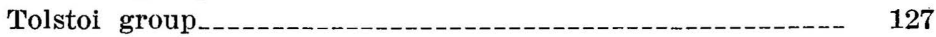

Big Five claim

Kasaan Bay prospects_-_._- 127

Sunny Day group_._-_._- 127

Shelton group

Niblack Anchorage_-_._-_._- 128

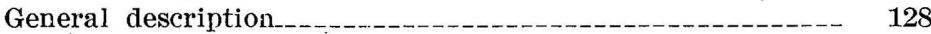

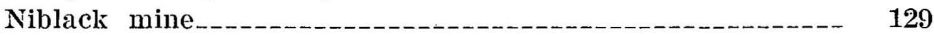

Lookout group_-__-_. 131

Copper Cliff mine

Wakefield group

North Arm of Moira Sound_______________ 132

General description

Cymru mine

Skowl Arm

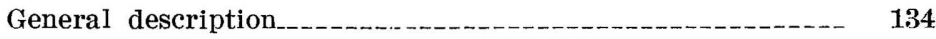

Khayyam mine-_--_-_-_- 135

Mammoth group.-_- 137

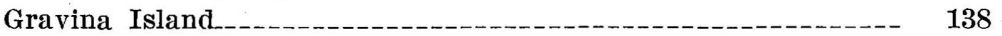

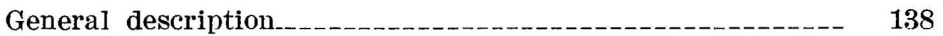

Prospects at Seal Bay and Dall Head_-_-_-_-_-_-_-_-_-_ 138

Prospects at Vallenar Bay

Duncan Canal___. 140

General description

Portage Mountain group

Kupreanof group.-_- 141

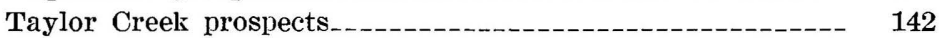

Gold mines_-_-_-_-_-_._- 142

General statement_-_-_-_-_-_-_-_-_- 142

Thorne Arm

George Inlet_-_-_- 149

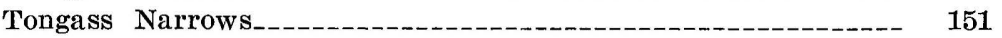

Cleveland Peninsula._-_-_-_- 152

Twelvemile Arm

General description

Prospects in the vicinity of Hollis._._._._._._._._. 159

Prospects on Granite Mountain 
Detailed descriptions of mines and prospects-Continued. Page.

Gold mines-Continued.

Cholmondeley. Sound__._- 166

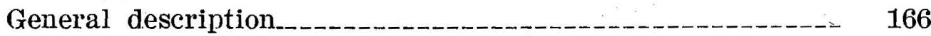

Prospects south of Cholmondeley Sound_______......_. 166

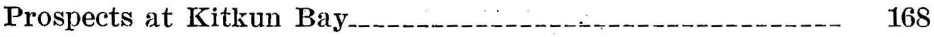

Prospects at head of Dora Bay_____ 171

Dolomi _._.

Prospects on south side of North Arm

Gravina Island

General description

Goldstream group________ 177

Heckman group _.......... 179

Moonshine group__._. 179

Annette Island_.___.__ 179

Dall Island......._. 180

Baker Island___._._._._._._. 181

Woewodski Island _._.

Woronkofski Islanḍ___._._._. 184

Smeaton Bay prospects_...._._. 185

Unuk River prospects____- 185

Silver, lead, and zinc mines_._._. 186

General description -...- 186

South Arm of Cholmondeley Sound.

Moonshine group____ 187

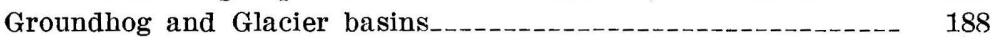

Coronation Island prospects_._._. 190

Building stones..._. 191

General statement___._. 191

Marble _._.

Distribution _....... 191

Necessary qualities_._._._._. 192

Competitive districts_..._- 192

Description of localities of occurrence_...................... 192

Prince of Wales Island_._._._._.

Alaska Marble Compány

El Capitan Marble Compnny

Marble Island _... 196

American Coral Marble Company

Revillagigedo Island_.._- 197

Ham Island _._.

Granite _.._.

Distribution _._.

Characteristics _._.

Market__.___._. 199

Cement

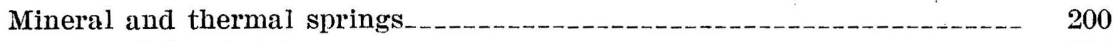

Future of the districts________._. 202

Index . 


\section{ILLUSTRATIONS.}

PLATE I. Geologic reconnaissance map of the Ketchikan and Wrangell

Page. mining districts; with two cross sections_____.___._. In pocket.

II. Geologic and topographic reconnaissance map of the eastern portion of the Ketchikan mining district; with one cross section In pocket.

III. Geologic and topographic reconnaissance map of the eastern portion of the Wrangell mining district; with one cross section In pocket.

IV. General map of southeastern Alaska 22

- V. $A$, View from Boundary Peak; $B$, View from Mount Anvil, Annette Island.

VI. Kloochman Canyon, Stikine River

VII. $A$, Interstratification of slate beds and greenstones, north end of Cleveland Peninsula ; $B$, Flat-lying graywacke beds, north end of San Fernando Island

VIII. A, Closely folded and highly crystalline schists adjacent to Coast Range intrusives, Bradfield Canal; $B$, Aplite and pegmatite dikes cutting crystalline schists, Bradfield Canal

IX. Geologic map of vicinity of Hetta Inlet, west coast Prince of Wales Island, showing positions of mines and prospects

X. $A$, Smelter, tramway, and mine workings on Copper Mountain ; $B$, Surface workings on crest of Copper Mountain

XI. $A$, Stevenstown mine workings, showing ore body; $B$, Hadley, showing smelter plant

XII. A, Marble blocks ready for shipment, from Marble Creek deposits; $B$, Marble quarry workings of the Alaska Marble Company, Prince of Wales Island

Fic. 1. Map of Kasaan Peninsula, showing mine locations

2. Map showing properties of the Brown Alaska Company, Hadley Consolidated Company, and the Mount Andrew Mining Company

3. Plan and cross section of Mount Andrew mine workings, showing positions of ore bodies

4. Map showing mines and prospects adjacent to Karta Bay

5. Sketch plan and section of mine workings, showing ore bodies at Rush \& Brown mine

6. Map showing position of mine at head of Niblack Anchorage

7. Sketch map of Moira Sound, showing location of mines and prospects

8. Sketch map of McKenzie Inlet, showing mine locations

9. Plan and cross section of Khayyam mine workings, showing positions of the ore bodies 
Fig. 10. Sketch map of Seal Cove and Dall Head, showing locations of prospects

Page.

11. Map showing location of Portage Mountain and Kupreanof groups of claims and prospects at the head of Duncan Canal--

12. Map showing claim locations near Sealevel, at head of Thorne Arm

13. Sketch map showing location of prospects adjacent to George Inlet and Tongass Narrows.

14. Sketch map showing positions of prospects and mining claims at Helm Bay, Cleveland Peninsula

15. Sketch map showing location of claims near Twelvemile Arm, Prince of Wales Island._._.

16. Sketch map showing positions of prospects in vicinity of Cholmondeley Sound and Dora Lake.

17. Map of Kitkun Bay, showing location of prospects

18. Sketch map showing mines and prospects near Dolomi, Prince of Wales Island

19. Sketch of mine workings at Valparaiso mine, Dolomi, showing position of ore shoot

20. Sketch map of Woewodski Island, showing positions of mining claims

21. Sketch map showing positions of prospects on Unuk River and near the international boundary line

22. Sketch map showing location of Groundhog Basin and Glacier Basin prospects.

23. Sketch map showing marble quarry and locations of Alaska Marble Company 


\section{PREFACE.}

By Alfred H. Brooks.

Though southeastern Alaska, beciuse of its important mining interests, was one of the first fields in the Territory to be investigated by the Geological Survey, yet up to 1902 the work in this region had not advanced beyond the cursory examination of some of the more important districts. In 1902 a topographic survey of a small area near Juneau was completed, and was followed during the next year by the geologic mapping of the same area and the extension of a geologic reconnaissance over a considerable adjacent region. The publication of the results of these surveys ${ }^{a}$ marks the first steps in the systematic investigation of this field. The present report embodies the results of the extension of these studies southward to the southern boundary of the Territory. With its publication a preliminary statement of the mineral resources of the three most important mining districts of southeastern Alaska-the Juneau, the Wrangell, and the Ketchikan-will have been issued.

The main object of this publication is to meet the needs of the mining engineers and prospectors, and only so much of the general geology has been incorporated as is necessary to the understanding of the occurrence of the commercially valuable mineral deposits. By this policy it is possible to present some of the economic results of the investigations before the completion of the geologic studies. A more complete exposition of the geology will be presented when the field has been more exhaustively studied.

In such a report only the general features of the occurrence of the ore bodies can be presented. A final analysis of the various problems connected with the genesis and occurrence of the ores must await detailed surveys. Such geologic surveys must be preceded by topographic mapping and hence can be carried on only very slowly. This phase of the work has not been neglected, for two important mining districts, Berners Bay and Kasaan Peninsula, have been mapped topographically, and the latter is being studied by geologists as this paper goes to press.

a Spencer, A. C., The Juneau gold belt, Alaska,; Wright, C. W., A reconnaissance of Admiralty Island, Alaska: Bull. U. S. Geol. Survey No. 287, 1906, 161 pp., 37 pls. 



\title{
THE KETCHIKAN AND WRANGELL MINING DISTRICTS, ALASKA.
}

\author{
By Fred Eugene Wright and Charles Will Wright.
}

\section{INTRODUCTION.}

\section{GENERAL STATEMENT.}

This report deals mainly with the mineral resources of the Ketchikan and Wrangell mining districts, but an introduction, presenting a summary of the general facts so far as known concerning the geology of the region, is necessary. As few detailed studies have been made except those of individual prospects and mines, the work must be regarded as preliminary. Each year since 1904 a summary report ${ }^{a}$ of the mining developments and economic resources in the districts has been published; and on account of these publications and the ever-changing conditions of the mines more attention will be given in this paper to the geologic relations and characteristics of the ore deposits than to the details of mining development. Building materials of economic value, including marble, granite, and cement, are also considered briefly, and attention is directed to their increasing commercial importance. This report and the report on the Juneau gold belt by A. C. Spencer ${ }^{b}$ complete the preliminary description of the important mining districts of southeastern Alaska. Though the results obtained during the rapid reconnaissance of this large area do not present the refinements of detailed work, it is hoped that their presentation in the following pages will give a fairly correct impression as to the distribution, character, and relative importance of the ore bodies and ore-bearing formations in this section of Alaska.

Both field and office work for this report have been carried on under the direction of Alfred $\mathrm{H}$. Brooks, and to him the writers are greatly indebted for many valuable suggestions; they are also

a Bull. U. S. Geol. Survey No. 259, 1905, pp. 47-87 ; No. 284, 1906, pp. 30-60 ; No. 314, 1907, pp. 47-81.

${ }^{b}$ Spencer, A. C., The Juneau gold belt, Alaska: Bull. U. S. Geol. Survey No. 2S7, 1906. 
indebted to E. M. Kindle and G. H. Girty for the study of and the reports on the fossil collections from this area.

The mine owners, operators, and prospectors of the district, without exception, extended to the writers a most cordial cooperation and many courtesies, which are gratefully acknowledged. It is not possible to give the names of all who have aided in this investigation, but the work was especially facilitated by James Bawden, of Ketchikan; U. S. Rush, of Kasaan; B. A. Eardly, of Dolomi; J. L. Parker, of Hadley; William B. Freeburn, of Mount Andrew ; Barton B. Neiding, of Niblack; Henry W. Mellen, of Coppermount; Charles A. Sulzer, of Sulzer; W. McLeod, of Dall Island; Charles E. Nassen, of Shakan, and Charles Nelsor, of Wrangell.

To W. A. Langille, forest supervisor of the Alexander Archipelago, the writers are indebted for the information regarding the distribution and value of the timber in the region.

\section{FIELLD WORK.}

The present reconnaissance embraced a land area estimated at 14,500 square miles and includes the portion of the mainland extending from Portland Canal on the south to a line running due east from Cape Fanshaw to the International Boundary, and those islands of the Alexander Archipelago south of Frederick Sound and Sumner Strait. The Ketchikan district to the south is separated from the Wrangell district to the north by a line through Sumner Strait around the north end of Prince of Wales Island, down Clarence Strait as far as Ernest Sound, up Ernest Sound, along Bradfield Canal eastward, and across the mountain range to the International Boundary.

Field work in the Ketchikan district was first undertaken by Brooks in 1901, and the observations included in his report ${ }^{a}$ issued the following year were used as a basis for the present investigation.

Field work was begun by the writers May 16, 1905. F. E. Wright started from Ketchikan and made a study of Revillagigedo Island, while C. W. Wright and E. M. Kindle went to Juneau and from there, using a launch, visited the known fossil localities, made collections, and studied the stratigraphic relations on Admiralty, Kuiu, and Kupreanof islands. This work was completed June 20, at which time the writers met at Ketchikan and were joined by Alfred $\mathrm{H}$. Brooks. The entire party then made a study of the geologic section across the Coast Range as exposed from Ketchikan to the head of Portland Canal, and returned to Ketchikan June 30. From July 1 to July 10 Annette Island and a portion of the east coast of Prince of Wales Island were visited. F. E. Wright remained in this region to make detailed investigations of the mining areas, while $\mathrm{C}$. W.

a Brooks, A. H., Ketchikan mining district: Prof. Paper U. S. Geol. Survey No. 1, 1902. 
Wright continued the general geologic mapping around Prince of Wales Island. The latter completed his work and returned to Juneau August 15, and from this date to September 18 was engaged in an investigation of the mines and prospects in the Juneau district. ${ }^{a}$ During the latter part of September and until October 20, 1905, he studied the copper deposits in the vicinity of Copper Mountain. F. E. Wright continued his work in the Ketchikan district and.on August 31 went north to Wrangell, where he studied the Coast Range belt and ore deposits of the Wrangell district. This work was com? pleted October 10, 1905.

As only three months were devoted to the field work in the Ketchikan and Wrangell districts and as more than half of this time was used at the mines, the geologic mapping had to be pushed forward as rapidly as possible, and many important features were barely touched upon. Nearly 2,000 miles of shore line were hastily traversed, and the geologic mapping was confined principally to the rock exposures along the shores of the island and mainland. These shores are generally rocky, few sand, beaches interrupting the continuity of the rock exposures, but, as it was necessary to traverse from 20 to 60 miles of coast line in a day, only the broad geologic features could be noted, and wide areas in the central parts of the island still remain unexplored. This work, especially along the west coast of Prince of Wales Island, was much hampered by the lack of charts, and it was necessary to make a sketch survey of portions of the coast line in conjunction with the geologic mapping.

During the latter part of September, 1906, and the first week of October, after the completion of the season's field work in the Sitka and Skagway districts to the north, C. W. Wright spent three weeks in the Ketchikan district, investigating the mine developments.

MAPS.

The charts of the Coast and Geodetic Survey and the results of reconnaissance surveys from 1890 to 1895 were used as base maps and found to be accurate to the scale. No accurate survey charts along the west coast of Prince of Wales Island and the adjacent islands have been issued, and the published maps of this area were found to be inadequate and had to be supplemented by sketch surveys made by the writers. As the Coast and Geodetic Survey has now begun work in this area, good charts will soon be available. The relief has been mapped in only the eastern part of the province, where topographic surveys have been made by the Canadian Boundary Commission.

Three general maps accompany this volume (Pls. I, II, and III, in pocket). Pl. I, a general map on a scale of about 10 miles to an

${ }^{a}$ Wright, F. E. and C. W., Report on progress of investigations of mineral resources of Alaska: Bull. U. S. Geol. Survey No. 284, 1906, pp. 31-40, 
inch, includes both the Ketchikan and Wrangell districts and is compiled from the charts of the Coast and Geodetic Survey, supplemented by sketch maps made by the writers. On this the geology has been represented and also the location of the mines and prospects. The scale of this map is not sufficiently large to include all the names of localities referred to, but these will be found on maps of larger scale. On the other two maps (Pls. II and III), which are contoured sheets of the mainland portion of the province, the geology is plotted in more detail. The contouring of these sheets is taken from the maps of the Canadian Boundary Commission, prepared in 1902 on a scale of $1: 160,000$, but here reduced to $1: 250,000$, or about 4 miles to the inch, which is also the scale of the map of the adjacent mainland belt to the north already published. ${ }^{a}$ The contour interval is 250 feet, each 1,000-foot contour being emphasized by a heavier line. Sketch maps, introduced throughout the text to show the positions of mining properties, have been furnished for the most part by the mine owners themselves.

\section{LITERATURE.}

The first authoritative information in regard to the geology and mineral resources of the Wrangell and Ketchikan districts is the report of W. P. Blake, ${ }^{b}$ who made a reconnaissance of the Stikine River in 1863 and whose notes were subsequently published as a Congressional document.

The early explorations of George M. Dawson ${ }^{c}$ in 1888 present the first systematic work along the Coast Range in southeastern Alaska. At this time Dawson made geologic sections across the Chilkoot Pass and up Stikine River, and both his maps and geologic records are valuable contributions. In 1891 C. Willard Hayes ${ }^{d}$ amplified Dawson's studies of the Coast Range by an intermediate geologic section along Taku Inlet and up Taku River, thus adding largely to our knowledge of the stratigraphy. of southeastern Alaska.

The following year investigations were made in the northern portion of southeastern Alaska by H. F. Reid ${ }^{e}$ and H. P. Cushing, ${ }^{f}$ who made a study of the glaciers and geology of Glacier Bay in 1890-1892,

${ }^{a}$ See Pl. XXXVII in the Juneau gold belt, Alaska: Bull. U. S. Geol. Survey No. 287, 1906, in pocket.

${ }^{b}$ Blake, W. P., Geographical notes upon Russian America and the Stikine River: House Ex. Doc. No. 177, pt. 2, 40th Cong., 2d sess.

$c$ Dawson, G. M., Report on an exploration in the Yukon district and adjacent portions of British Columbia : Geol. Nat. Hist. Survey Canada, vol. 3, pt. 1, 1887-8, pp. 1-277 B ; Geological record of the Rocky Mountain region in Canada: Bull. Geol. Soc. America, vol. 12, 1901, pp. 57-92.

${ }^{d}$ Hayes, C. W., An expedition through the Yukon district: Nat. Geog. Mag., vol. 4, 1892, pp. 99-162.

e Reid, H. F., Studies of the Muir Glacier: Nat. Geog. Mag., vol. 4, 1892-93; Glacier Bay and its glaciers: Sixteenth Ann. Rept. U. S. Geol. Survey, pt. 1, 1896, pp. 421-461.

$t$ Cushing, H. P., Notes on the geology in the vicinity of Muir Glacier: Nat. Geog. Mag., vol. 4, 1892-93; Notes on the Muir Glaçier region and its geology : Am. Geologist, Fol. 8, 1891, pp. 207-230. 
and by William H. Dall ${ }^{a}$ and George F. Becker, ${ }^{b}$ who visited southern Alaska in 1895 to study its gold and coal resources. They visited a number of localities in the Juneau and Sitka districts and along the coast to the northwest, but at that time practically nothing was known of the mineral resources of the Ketchikan and Wrangell districts.

In the reports of the Harriman Alaska Expedition, which made a cruise along southeastern Alaska and westward in 1899, B. K. Emerson ${ }^{c}$ and C. Palache ${ }^{d}$ published notes on the lithology and mineralogy of the rocks and ores from various points in southern Alaska.

The most important contribution to the geology of the Ketchikan district and the only extensive report on that area thus far published was made in 1901 by Alfred H. Brooks. ${ }^{e}$ The same year Brooks completed a hasty reconnaissance northward as far as Skagway and thence westward to Sitka. In this report not only the areal and structural geology of the Ketchikan district is discussed in considerable detail, but also a geologic correlation of this section with other parts of southeastern Alaska, taken from his data and that of previous investigators, has been included in an introductory sketch of the geology of southeastern Alaska. In 1903 Arthur C. Spencer ${ }^{f}$ assisted by C. W. Wright, made a study of the Juneau gold belt, including the mainland strip from Windham Bay to Berners Bay, and in the same year C. W. Wright made a reconnaissance of the Porcupine district ${ }^{g}$ to the northwest. During the years 1904 to 1906 the writers have extended the geologic reconnaissance mapping so as to cover nearly all of southeastern Alaska, and each year a summary report of the results pertaining especially to the economic development of the region has been published. ${ }^{h}$ The most complete report on Alaska as a whole is by Alfred H. Brooks, ${ }^{i}$ published in 1906. This includes a description of the geography of southeastern Alaska and a correlation of the geology of this section with that of other parts of Alaska and British Columbia.

a Dall, W. H., Coal and lignite of Alaska: Seventeenth Ann. Rept. U. S. Geol. Survey, pt. 1, 1896, pp. $763-908$.

${ }^{b}$ Becker, G. F., Gold fields of southern Alaska: Eighteenth Ann. Rept. U. S. Geol. Survey, pt. 3, 1898, pp. 1-86.

c Emerson, B. K., Notes on the stratigraphy of igneous rocks: Harriman Alaska IExpedition, vol. 4, 1904, pp. 11-66.

d Palache, C., Notes on the minerals collected: Harriman Alaska Expedition, vol. 4, 1904 , pp. 92-96.

${ }^{e}$ Brooks, A. H., Ketchikan mining district: Prof. Paper U. S. Geol. Survey No. 1, 1902.

$f$ Spencer, A. C., The Juneau gold belt: Bull. U. S. Geol. Survey No. 287, 1906, pp. $1-137$.

g Wright, C. W., The Porcupine placer district, Alaska: Bull. U. S. Geol. Survey No. 236, 1904.

${ }^{h}$ Wright, F. E., and C. W., Bull. U. S. Geol. Survey No. 259, 1905, pp. 47-68; Bull. U. S. Geol. Survey No. 284, 1906, pp. 30-54, 55-60; Bull. U. S. Geol. Survey No. 314, 1907 , pp. 47-72, 73-81.

${ }^{i}$ Brooks, A. H., Geography and geology of Alaska, Prof. Paper U. S. Geol. Survey No. 45, 1906 . 


\section{HISTORY OF MINING DEVELOPMENTS.}

KETCHIKAN MINING DIS'RRICT.

Prior to the year 1897 the Ketchikan district, which forms the most southern portion of Alaska, had not been investigated, though many prospectors had passed through it on their way north to central Alaska and to the vicinity of Juneau. Moreover, not until 1898 did mining actually begin in the district. During the period of Russian possession of Alaska little or no attempt was made to investigate its mineral resources. Though it seems certain that the Russians had knowledge at least of the existence of some deposits of chalcopyrite ore which form extensive outcrops at tide water in Kasaan Bay, the. development of these and other metalliferous deposits was consistently avoided.

Subsequent to the transfer of Alaska to the United States, Charles Baronovich, a Russian merchant, is reported to have located the first copper prospect in the district just south of Kasaan village, where the Copper Queen claim is now located. The comparative isolation of this district and the fact that large bodies of native copper had been found in the Lake Superior region are probably the reasons that these sulphide deposits attracted but little attention.

In the early seventies gold was reported from Unuk River, but the principal gold fields at this period were farther north, at the headwaters of Stikine River and in the Cassiar region, and little attention was given to the Unuk River deposits. During the succeeding years the gold deposits of the northern part of southeastern Alaska at Juneau attracted most of the prospectors, and the Ketchikan district was entirely neglected. Petrof, in the Tenth Census report, ${ }^{a}$ mentions a mine which had been opened on Prince of. Wales Island and had subsequently been closed. Though he does not give the location of the mine, it is probable that he refers to the early prospects near the present location of the Copper Queen claim, on the north side of Kasaan Bay. Some small shipments of copper ore appear to have been made at this time. ${ }^{b}$ In the Eleventh Census report Bruce ${ }^{c}$ makes the following statement:

The indications on the surface are that Prince of Wales Island contains much mineral. Gold, both free milling and in sulphides, silver, galena, copper, and iron have been found in many places, but as yet no extensive efforts have been made to demonstrate whether any of the ores mentioned exist in paying quantities. If minerals exist in other portions of the district, the very limited pros-

\footnotetext{
a Population, industries, and resources of Alaska: Petrof, Ivan, Tenth Census of the Tinited States, 1884, p. 77.

$b$ Compare No. 215, Tenth Census of the United States, p. 800 .

$c$ Bruce, M. W., Population and resources of Alaska: Eleventh Census of the United States, 1890, p. 39 .
} 
pecting done has failed to show it. Annette Island may be an exception, and aIso Dall Island. Some of the finest specimens of gold-bearing ore I have seen in my journey are said to have been taken from Dall Island.

The men engaged in salmion fishing, many of whom had a knowledge of prospecting, were the next to interest themselves in the search for ore bodies in the Ketchikan region. These men explored the coast line and made many locations upon auriferous quartz veins and copper deposits. In the early nineties mining men became interested in these finds and some minor developments were made. Prominent among these men was James Bawden, who discovered in 1892 what he believed to be workable gold deposits on the eastern side of Annette Island.

In 1893 William Barnard relocated the copper prospects just south of Kasaan village and discovered other prospects in the near vicinity. Discoveries on Gravina Island and near Boca de Quadra were made in $1897,{ }^{a}$ and in the succeeding year a number of important locations were made, notably the Gold Standard and other claims on Cleveland Peninsula, the copper prospects at Dall Head on Gravina Island, the gold veins at Dolomi and at Sea Level, and the many discoveries of copper ore on Kasaan Peninsula and on Copper Mountain.

In 1899 discoveries were made at Hollis, at Skowl Arm, and at Niblack Anchorage, and developments were actively advanced at most of the other properties. The two years following were years of great mining excitement in the Ketchikan district, many hundreds of mineral claims were staked, and at a number of localities systematic mining was begun. The developments of this region up to the summer of 1901 are set forth in much detail in the report of $\mathbf{A}$. H. Brooks $^{b}$ on the Ketchikan mining district.

Up to this time the Ketchikan mining district was included within the boundaries of the Wrangell recording district, with the recording place at Wrangell. Because of the mining interest in the vicinity of Ketchikan, the United States district court issued the following orders :

Order, that boundaries of the Wrangell recording district No. 1 be so far modified as to exclude from boundaries of said district No. 1 that part thereof as follows:

Beginning at a point on said western boundary line of district No. 1 south of where the same enters Chatham Straits and at a point from which, running due east, will pass the most southern point of Coronation Island 5 miles south of the same, and running northerly along the center of Summer Strait around the most northerly end of Prince of Wales Island to a point where the same joins Clarence Straits and half way between the most westerly point of Zarembo Island and the most easterly point of Point Colpoys on Prince of Wales Island; thence along the center of Ernest Sound ; thence running in a northeasterly direc-

\footnotetext{
a Report of the Governor of the District of Alaska, 1897, p. :31.

Brooks, A. H., Ketchikan'mining district: Prof. Paper U. S. Geol. Survey No. 1, 1902, pp. 35-116. 40840-Bull. 347-08-2
} 
tion up the center of Ernest Sound and north of Deer Island to the center of Bradfield Canal; thence in an easterly course along Bradfield Canal to the head thereof; then in a due easterly direction to the said International Boundary line; thence along said boundary line in a southeasterly direction through Portland Canal and Portland Inlet to Cape Fox; thence westerly along said boundary line through Dixon's Entrance to a point due south of the center of Chatham Straits; thence due north to the place of beginning.

Further ordered, that area within boundaries thus established be known as the Ketchikan recording district No. 8.

To be in force after December 1, 1901.

Since 1901 rapid progress has been, made within the district, and several large new mines have been located and developed to a producing stage. In 1903-4 a 250-ton smelter was erected at Copper Mountain, and in 1905 smelting operations began. At Hadley, on Kasaan Peninsula, a 350-ton smelting plant was built in 1903-4, and here also smelting of the ores began late in 1905 . The building of long tramways and wharves at Niblack, Skowl Arm, Karta Bay, Hetta Inlet, and other localities has greatly increased the facilities for mining.

The town of Ketchikan, the official headquarters of the district, is on the west side of Revillagigedo Island and on the east side of Tongass Narrows. It was first located in 1888 as a cannery site with a general trading store, and in 1900 it was incorporated as a town. The town has now a population of about 1,200 and includes two wellequipped hotels and several large outfitting and general trading stores. By steamer route it is 660 miles northwest of Seattle and 240 miles southeast of Juneau. Ketchikan, as it is situated just 60 miles north of the southern boundary line, is the first port of entry and the last port of departure for all vessels engaged in commerce in southeastern Alaska and the commercial distributing point for this portion of the region. It is connected by cable with Seattle and the principal ports in southeastern Alaska: Besides the mining interests there are six salmon canneries, sawmills, and various other industries of commercial importance in the district.

\section{WRANGELL MINING DISTRICT.}

Fort Wrangell was established by the Russian-American Fur Company nearly a hundred years ago and received its name from Baron von Wrangell, the second Russian governor. From 1837 to 1847 it was a trading post of the Hudson Bay Trading Company, which still has a station up Stikine River in British Columbia.

Gold was first reported on the bars of Stikine River as far back as 1862, and in 1863, word having been received at Sitka of this discovery, the Russians sent an expedition to Stikine River to find out whether these discoveries were in Russian territory and to establish 
the boundary between the Russian and English possessions. W. P: Blake, an American geologist, accompanied this expedition as a volunteer and made notes on the geology of the region and on the oceurrence of placer gold, which were subsequently published as a Congressional document. ${ }^{a}$ This constitutes the first authoritative information in regard to the mineral resources of southeastern Alaska.

During the early seventies discoveries of placer gold in the Cassiar district of British Columbia attracted hundreds of gold seekers from various countries to Fort Wrangell, whence they journeyed up Stikine River to near its source in the Cassiar district. This, however, was a long and difficult trip, and many of the gold seekers began prospecting in the vicinity of Wrangell, some working northward into the Juneau district. Mineral locations were made in the following years on deposits of gold, copper, and silver-lead ores, but as a whole this section remained comparatively idle until the Klondike excitement in 1897-98. Then Wrangell again became an important transhipment point, because Stikine River became one of the routes to the interior. At this time prospecting was again advanced in the Wrangell district, though with little success. In 1900-1901 considerable work was done on the gold and copper deposits on Woewodski Island by the Olympic Mining Company. A lárge stamp mill was erected, wharves were built, and other surface improvements were made, but operations were soon suspended. The Wrangell district, though it has not advanced beyond the prospecting stage, contains promising mineral deposits both along the mainland and on the adjacent islands. Several salmon canneries and a large sawmill at Wrangell constitute the principal resources of the district.

The town of Wrangell, with a population of about 1,000, including the natives, is 160 miles south of Juneau, is the distributing point for the Wrangell district, and is also the official headquarters. It is still the supply port for the interior mining camps of British Columbia tributary to Stikine River, and during the summer months a large river steamer makes stated trips between Wrangell and Telegraph Creek, 170 miles up the river.

\section{PRODUCTION.}

The following table shows the total metal production for. 1905 and 1906 of the ores derived from the copper mines in the Ketchikan district. The second table shows the average content per ton of ore. Outside of the Ketchikan district there are no. producing copper mines in southeastern Alaska. 
Total production from copper mines in the Ketchikan district, 1905 and 1906.

\begin{tabular}{|c|c|c|c|c|c|c|c|c|}
\hline \multirow{2}{*}{ Yea:. } & \multirow{2}{*}{$\begin{array}{l}\text { Ore, } \\
\text { short } \\
\text { tons. }\end{array}$} & \multicolumn{2}{|c|}{ Copper. } & \multicolumn{2}{|c|}{ Gold. } & \multicolumn{2}{|c|}{ Silver. } & \multirow{2}{*}{$\begin{array}{l}\text { Total } \\
\text { value. }\end{array}$} \\
\hline & & Pounds. & Value. & Ounces. & Value. & Ounces. & Value. & \\
\hline 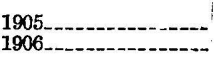 & $\begin{array}{l}30,400 \\
85,139\end{array}$ & $\begin{array}{l}1,901,392 \\
4,350,571\end{array}$ & $\begin{array}{r}\$ 295,616 \\
838,660\end{array}$ & $\begin{array}{l}1, \overline{\mathrm{i}} 78 \\
3,031\end{array}$ & $\begin{array}{r}\$ 34,370 \\
62,851\end{array}$ & $\begin{array}{l}13,000 \\
27,152\end{array}$ & $\begin{array}{l}\$ 7,867 \\
18,102\end{array}$ & $\begin{array}{r}\$ 337,853 \\
919,613\end{array}$ \\
\hline
\end{tabular}

Average content per ton of ore from copper mines in the Ketchitan district, 1905 and 1906.

\begin{tabular}{|c|c|c|c|c|c|c|c|}
\hline \multirow{2}{*}{ Year. } & \multicolumn{2}{|c|}{ Copper. } & \multicolumn{2}{|c|}{ Gold. } & \multicolumn{2}{|c|}{ Silver. } & \multirow{2}{*}{$\begin{array}{l}\text { Total } \\
\text { value. }\end{array}$} \\
\hline & Pounds. & Value. & Ounces. & Value. & Ounces. & Value. & \\
\hline 1905 & $\begin{array}{l}62.5 \\
51.1\end{array}$ & $\begin{array}{r}\$ 9.75 \\
9.86\end{array}$ & $\begin{array}{r}0.038 \\
.036\end{array}$ & $\$ 0.78$ & $\begin{array}{r}0.43 \\
.32\end{array}$ & $\begin{array}{r}\$ 0.26 \\
.21\end{array}$ & $\begin{array}{r}\$ 10.79 \\
10.81\end{array}$ \\
\hline
\end{tabular}

In computing the value of the metal content of the ores the average values of silver and copper in 1905 and 1906 were taken, as follows: For 1905 , silver $=\$ 0.604$ per ounce, copper $=0.156$ per pound ; for 1906 , silver $=\$ 0.67$ per ounce, copper $=\$ 0.193$ per pound.

The total copper production of the district previous to 1905 is estimated at 1,600,000 pounds. At 12 cents per pound, the average price of copper for that period, the value of this is $\$ 192,000$. These amounts added to those for 1905 and 1906 give a total copper production of $6,251,963$ pounds and a total value of $\$ 1,134,276$.

The remarkable increase noted in the preceding tables from the mines in the Ketchikan district has brought this section of Alaska well to the front as a copper-producing region. Practically the first large shipments were made in the spring of 1905, and since that time the production has steadily increased. The rise in the price of copper from an average of $\$ 0.156$ a pound in 1905 to an average of $\$ 0.193$ a pound in 1906 has permitted the profitable extraction of copper ores of lower grade than those mined in 1905, and by the improvement in transportation and mining conditions it will be possible to mine ores still lower in metal content. In 1906 there were 10 producing copper mines in the districts,' whereas in 1905 only 6 were productive.

There are only a few gold mines in the Ketchikan and Wrangell districts and their output has been spasmodic. During 1906 only two gold mines were productive, though from several others there was a considerable output in previous years. Brooks estimated the total gold output in 1901 to be $\$ 100,000$. From 1901 to the end of 1906 the production from the gold mines is estimated at $\$ 120,000$. These amounts added to the gold production from the copper ores, which is approximately $\$ 110,000$, gives a total gold output of $\$ 330,000$. The silver production is estimated at $\$ 30,000$ from the copper ores, $\$ 16,000$ from the gold ores, and about $\$ 4,000$ from the silver-lead ores. 


\section{GEOGRAPHIC SKETCH OF SOUTHEASTERN ALASKA.}

Southeastern Alaska embraces an area of high relief, whose dominating feature is the Coast Range skirting the mainland on the east (Pl. IV). To the west it includes Alexander Archipelago, with its maze of waterways and numerous islands. These islands are also of high relief, but in general the uplands fall off toward the Pacific. The Pacific Mountain system as defined by Brooks ${ }^{a}$ embraces a broad zone of ranges lying parallel to the southern coast line of Alaska and forming with it a curve concave toward the south. Of these the Coast Range, the St. Elias Range, and the Aleutian Range lie adjacent to the coast, while the Alaska Range is inland and forms the northern border of the system. In southeastern Alaska the system includes the Coast Range and the seaward group of mountainous islands of Alexander Archipelago. The same general subdivision into a mainland Coast Range and an outlying mountainous belt, called the Vancouver Range by G. M. Dawson, ${ }^{b}$ continues into British Columbia, where it is more sharply marked. The Coast Range extends from southern British Columbia into southeastern Alaska, where it lies partly in Alaska and partly in Canada. To the northwest it passes inland behind the St. Elias Range and thence decreases in altitude, gradually merging into the interior plateau. A remarkable feature of this range, which was noted by Dawson ${ }^{c}$ and Hayes, ${ }^{d}$ is the uniformity of the summit levels, which present the appearance of a dissected plateau.

The mountain masses composing the outlying islands of southeastern Alaska, though separated from the St. Elias Range on the north by Cross Sound and not orographically connected, are geologically similar and, as suggested by Brooks, ${ }^{e}$ may properly be considered the southeastern extension of the St. Elias Range (Pl. IV).

From Dixon Entrance, the southern limit of Alaska, to Cross Sound, a distance of 500 miles, the islands and mainland are broken by an intricate system of waterways and fiords. Some of these reach fair inland, but they frequently run parallel with the coast. Chatham Strait, with its northern extension, Lynn Canal, is the longest fiord. It passes over three degrees of latitude, a distance of 250 miles, and is from 3 to 6 miles broad with a depth of from 1,000 to 2,500 feet. This fiord traverses the general trend of the mountain ranges and the bedrock structure at an angle of about $30^{\circ}$ and in this differs from

\footnotetext{
a Brooks; A. H., Geography and geology of Alaska : Prof. Paper U. S. Geol. Survey, No. 45,1906, p. 28.

- Trans. Roy. Soc. Canada, vol. 8, sec. 4, 1890, p. 4.

- Dawson, G. M., Report on the area of the Kamloops map sheet, British Columbia: Ann. Rept. Geol. Survey Canada, new ser., vol. 7, 1894, p. 10 B.

${ }^{d}$ Hayes, C. W., An expedition through the Yukon district: Nat. Geog. Mag., vol. 4, 1892, pp. 4-24.

e Op. cit., p. 29 .
} 
the other watercourses, which are either parallel to the coast line and trend of the rock beds or cut across them irregularly at much greater angles. Both the geology and the topography indicate that the position of Lynn Canal and its southern extension, Chatham. Strait, is determined by a line of faulting (Pl. IV). Other important fiords are Portland Canal (Pl. V, A), Clarence Strait, Behm Canal, Taku Inlet, and Glacier Bay, each of which has its own characteristics. These waterways, which are long, narrow, deep arms of the sea extending far back into the mountains, have been aptly compared with wide, slowly flowing rivers. The flow varies with the tide, the rise and fall averaging about 15 feet and causing strong eddies and currents between periods of high and low water. In southeastern Alaska these inland passages are known locally not as fiords but as canals, straits; inlets, coves, bays, sounds, and arms. They are a distinctive and dominating feature of the country and furnish both effective and safe routes of communication between different points of a region which is otherwise mountainous and difficult of access. The topography is so rough and uneven that only at great expense and in favored localities can even wagon roads be constructed and railroads of any length can hardly be considered. The fiords, however, not only are of the greatest value as highways of commerce, but possess a great commercial asset in the immense quantities of fish, especially salmon, halibut, and herring, which throng their waters at different seasons of the year. The ease with which transportation can be effected is also an important factor in mining operations and the lumber industry.

\section{GEOGRAPHY OF THE KETCHIKAN AND WRANGELL DISTRICTS.}

GENERAL STATEMENT.

The area considered in the present report, the Ketchikan and Wrangell districts, is located at the southern end of the Alaska panhandle; it begins at Portland Canal and is limited on the north by Frederick Sound. Its total land area approximates. 14,500 square miles, about one-third of which is included in islands. Of these Prince of Wales Island is the largest, and Revillagigedo, Kupreanof, and Kuiu islands are next in size. 


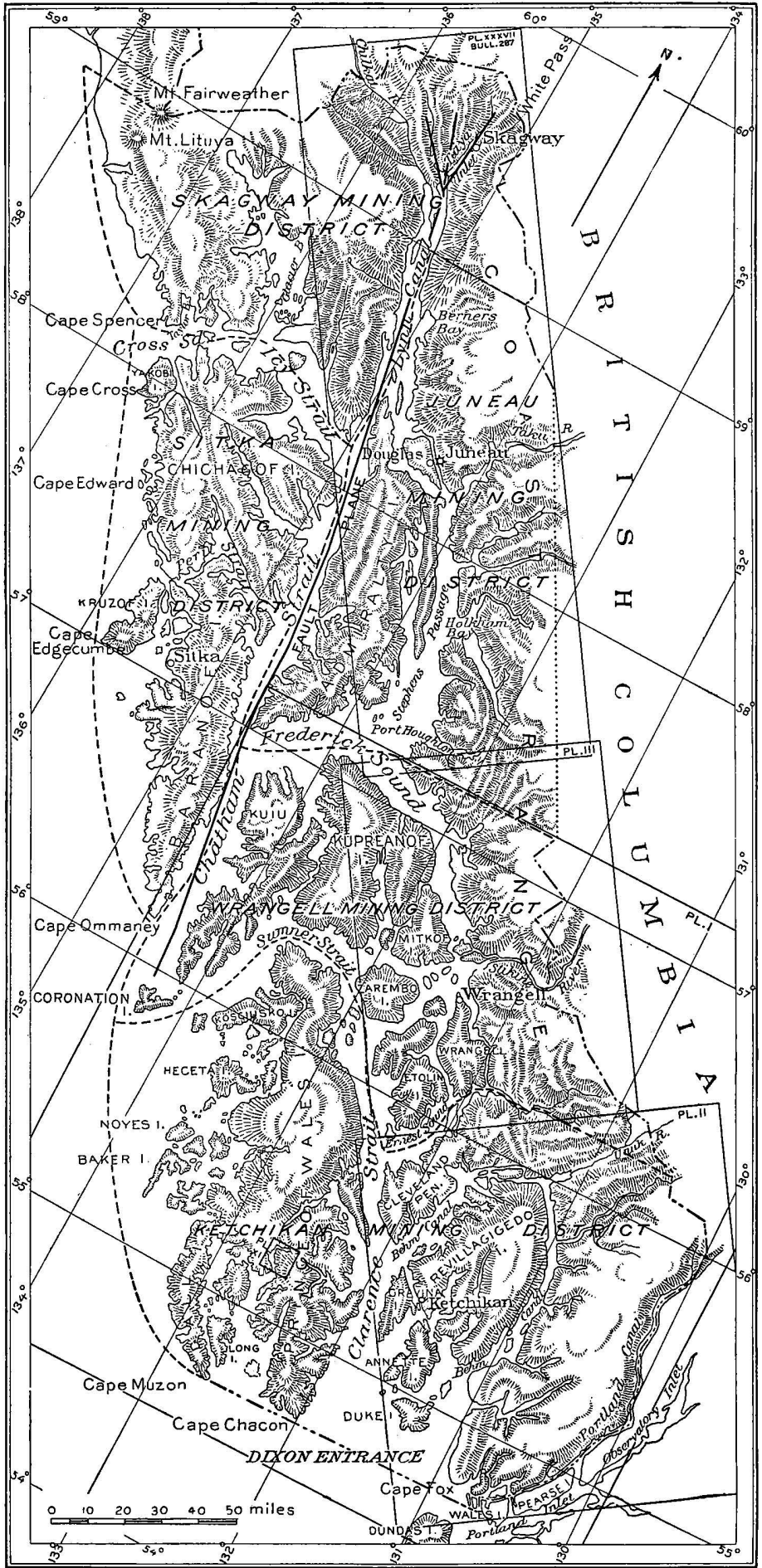

GENERAL MAP OF SOUTHEASTERN ALASKA.

Showing mining districts and areas covered by geologic maps in this report. 

In the following table an estimate is given of the area of the mainland and of the larger islands in each district:

\section{Areas of the Ketchikan and Wrangell districts.}

Ketchikan district:

Square miles

Mainland 4,050

Islands over 100 square miles in area:

Prince of Wales Island.

Revillagigedo Island. 1,120

Gravina Island

102

Annette Island _... 133

Dall Island

Kosciusko Island____._._. 160

Total of islands less than 100 square miles in area

Wrangell district:

Mainland

Islands over 100 square miles in area :

Kupreanof Island

1, 080

Kuiu Island..._. 750

Mitkof Island____. 200

Wrangell Island _.

Etolin Island_._. 330

Zarembo Island_._. 180

Total of islands less than 100 square miles in area______ $\quad 170$

Grand total

\section{MAINLAND BELT.}

The mainland belt includes the mainland area and the islands which lie east of a line extending from Dixon Entrance through Clarence Strait and Duncan Canal to Frederick Sound. In general aspect the topographic character of this eastern portion differs but little from that of the other portions of the Coast Range province to the north and south. The mountains rise abruptly, at some places in sheer cliffs, from tide water to elevations of 2,000 to 5,000 feet, and the peaks farther inland reach altitudes of 6,000 to 10,000 feet. These mountain masses are made up essentially of the immense batholiths of the Coast Range granite, ${ }^{a}$ and the land features are chiseled on a correspondingly broad scale. Owing to the mode of formation and physiographic development of these mountains, there is frequently a decided lack of bed-rock control of the lines of drainage or erosion. Though profoundly dissected, the mountains show a notable tendency to uniformity of elevation in the crest lines of their summits $(\mathrm{Pl}$. V, $A)$. These summits are usually broad and somewhat flat with gently arched backs, and if the intervening precipitous valleys were 
filled to their original profiles, there would be an undulating and warped surface sloping gradually seaward from the center of the range.

The land forms over the entire area indicate an intensely glaciated region which has been but slightly modified by water erosion since the glacial epoch. At the time of the maximum ice flooding, during the glacial epoch, the ice sheet covered the whole area with the exception of isolated high peaks which can be recognized at present by their sharp, serrated outlines and lack of glacial rounding. Even at the present time of glacial drought a number of small ice fields are still within the Coast Range belt of this area, located above snow line and sending small tongues down the valleys even to tide water. The special features of glacial sculpture, as U-shaped valleys, fiords, glacial erratics, cirques, hanging valleys, double cliff slopes, truncation of spurs and tendency toward perfect alignment of cliff bases, glacial grooves and strix, and roches.moutonnées, are developed to a remarkable degree within this area. The noticeable absence of moraines in such an area of extensive glaciation is due chiefly to the peculiar steepness of the mountain and valley slopes. Many of the fiords are floored by sand and gravel moraines and are frequently partially choked at their entrances by morainal material. Among the higher mountains inland small glaciers are present, and in Le Conte and Thomas bays they extend to tide water, but none were observed on the adjacent islands.

Forelands occur locally ( $\mathrm{Pl} . \mathrm{V}, A)$, but are of small extent, and the only large areas of level land in the region are at the mouths of the greater watercourses, notably at the mouth of Stikine River, where the counteraction of the tide and stream flow has caused the deposition of sands and muds and formed broad tide flats.

Peninsulas and islands adjacent to the mainland are separated by deep, narrow fiords extending many miles inland. Cleveland Peninsula, the largest of these promontories, is 10 to 15 miles wide and contains mountains whose summits reach over 4,000 feet in elevation. Revillagigedo Island is separated from the mainland by Behm Canal, a narrow, steep-sided fiord, which surrounds the eastern half. Its mountain tops range from 2,000 to 4,000 feet above sea level. George and Carroll inlets and Thorne Arm dissect this island and border narnow promontories whose altitudes reach about 3,000 feet.

The mainland belt is intricately dissected by narrow steep-sided valleys heading in mountainous canyons, many of which are filled with snow, or in glacial cirques, many of which contain small glaciers or patches of ice. The initial descent of these valleys is steep, the streams often forming beautiful waterfalls of great volume and power. Tributary creeks or rivers enter from both sides, the valleys gradually widen, and the valley floors become covered with a gravel 


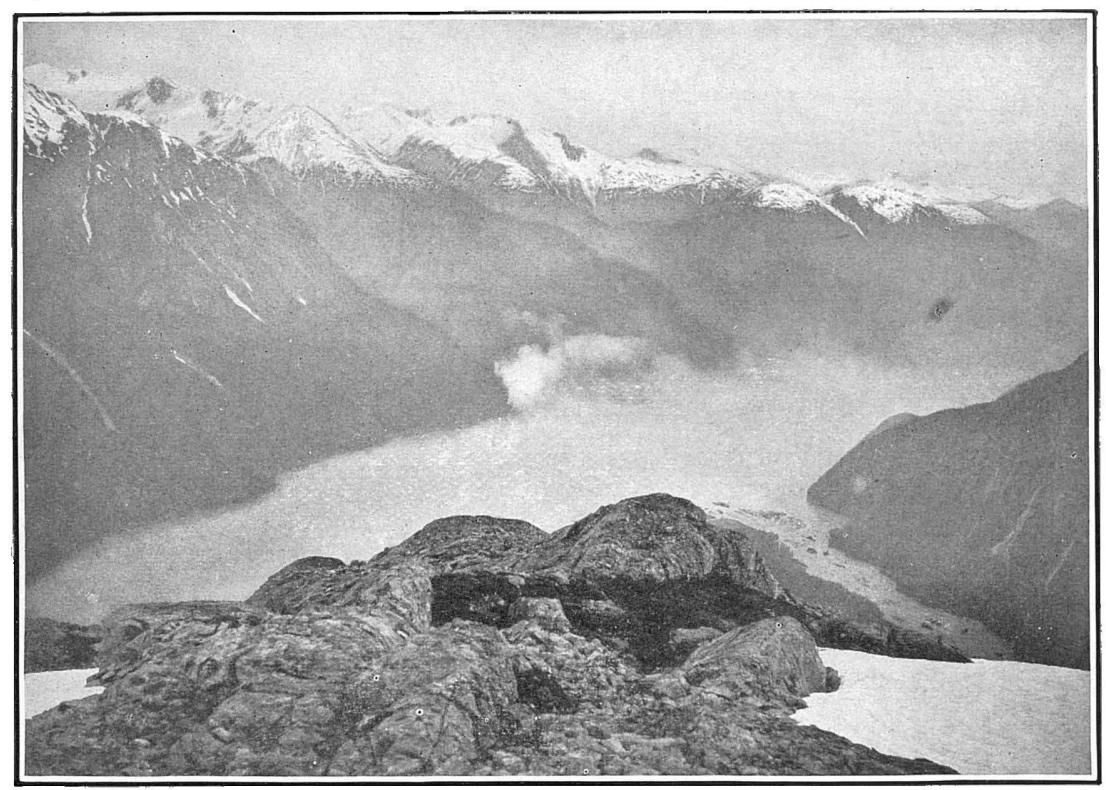

A. VIEW FROM BOUNDARY PEAK DOWN PORTLAND CANAL.

Showing abrupt topographic relief.

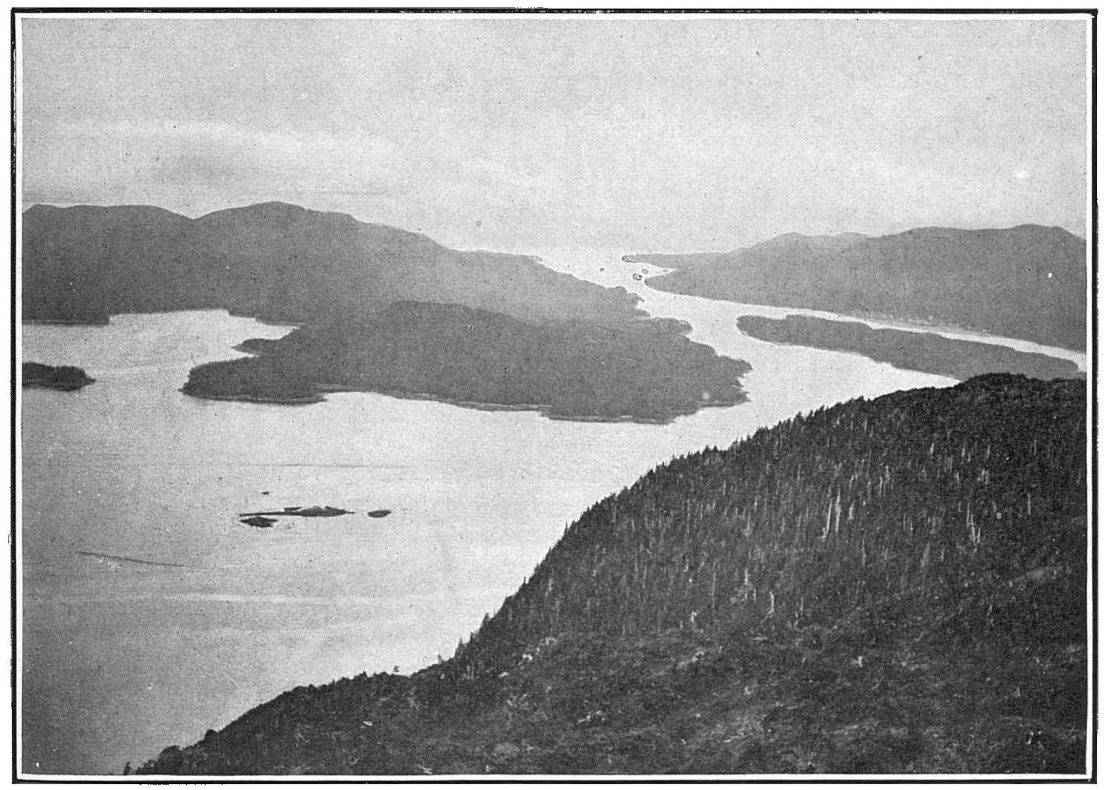

B. VIEW FROM MOUNT ANVIL, ANNETTE ISLAND, NORTH TOWARD KETCHIKAN,

Showing forelands and topographic sculpture of the islands adjacent to the mainland. 

wash consisting largely of gravel, cobbles, and bowlders of granite. As the grade decreases the gravel beds become deeper and wider and the stream flows around the flanks of precipitous mountain spurs and enters the sea at the head of some tidewater inlet. The tide flats at these points are usually wide and are composed of fine sand and mud, the depth to bed rock being probably several hundred feet. They extend into the channels for a short distance beyond the low-tide line and there end abruptly. Depths of 50 to 100 fathoms are common in these inlets a short distance from the shore.

The largest of these valleys is that of Stikine River (Pl. VI), which rises in British Columbia, crosses the Coast Range mountain divide, and forms a drainage valley for part of the inland plateau. Its numerous branches interlock (1) with the headwaters of Taku River; (2) with the streams flowing into the Yukon to the northeast; (3) with the streams tributary to Dease Lake and Dease River to the northwest, a part of the McKenzie River drainage; and (4) with the streams flowing south into Nass River. The upper valley of Stikine River, which here flows in a southwesterly direction, is broad and slopes at low angles. It changes, however, to a canyon as it begins to traverse the Coast Range, and in Kloochman, and Little canyons steep cliffs rise abruptly 1,000 feet or more on each side. Below Kloochman Canyon the river changes its course from a southwesterly to a general southerly direction, and 20 miles from its mouth it bends sharply to the west. Throughout its course in the mountains the effects of ice sculpture are visible and dominate the landscape. Several large glaciers, notably Flood Glacier, Dirt Glacier, Great Glacier, and Popof Glacier, still occupy tributary valleys and can be observed from the main valley. Stikine River reaches salt water at the head of Stikine Sound, 12 miles north of Wrangell, where a wide delta has been formed.

Among other river valleys are those of the Unuk and Chickamin, both large rivers and next in size to the Stikine. Their source, however, is on the western slope of the mountain divide and their valleys are more or less canyonlike to the sea, a distance of less than 60 miles.

The seaward extension of many of these valleys is represented by tide-water channels or fiords. The largest of these in this region is Portland Canal, which extends inland 150 miles, with an easterly and then northerly course (Pl. V, $A$ ). It is only a mile or two in width, from 100 to 200 fathoms deep, and the mountains rise to elevations of 4,000 to 6,000 feet a short distance inland from its sides. Bear and Salmon rivers enter at the head of this canal. Next in size is Behm Canal, which branches west and south from the mouth of Unuk River. The southern branch is much broader than Portland Canal, and several smaller river valleys and inlets are tributary to it from the east, as Smeaton Bay, Rudyerd Bay, Walker Cove, and Chickamin 
River. The west branch of Behm Canal is narrow at first, then it takes a southwesterly course and widens into a sound with many bays entering it. Among the smaller canals are Willard Inlet, Nakat Inlet, Boca de Quadra, and Bradfield Canal on the mainland, and Thorne Arm, Carroll Inlet and George Inlet on Revillagigedo Island.

SEAWARD ISLANDS.

There are no topographic maps of Prince of Wales, Kuiu, or Kupreanof islands, and little is known in detail of their valley courses or the trend of their mountain ranges. The shore line has been carefully mapped along the eastern portions of these islands, but much remains to be accomplished along the western coast, notably on Prince of Wales and Kuiu islands.

Prince of Wales Island is 80 miles long and 30 miles wide; its shore line is indented by numerous bays and inlets, which are characteristic of the entire coast. It is separated from the mainland by Clarence Strait, a deep channel about 4 miles wide, running north and south. Portions of the west coast are directly exposed to the Pacific Ocean, but most of it is protected by the small seaward islands, the largest of which is Dall Island. Viewed from the channels, Prince of Wales Island presents a mountainous mass of very irregular outline. Its relief, however, is less rugged than that of the mainland or of some of the islands to the north, such as Baranof Island. A low pass across the 1sland, 4 miles.long and less than 150 feet in elevation, connects the head of Cholmondeley Sound on the east with the head of Hetta Inlet on the west coast. Another pass, 6 miles long, unites the south arm of Cholmondeley Sound with Klakas Inlet. The head of Twelvemile Arm also is connected with Big Harbor on the west coast by a portage several miles long. Numerous lakes occur inland both in low-lying valleys and in basins from 1,000 to 2,000 feet in elevation. The mountain summits range in height from 2,000 to over 3,000 feet, the highest being Copper Mountain, 3,800 feet above sea level.

Still less is known of Kupreanof Island. On its north end are two small mountain'ranges; the one northeast of Kake village has summits reaching altitudes of 3,000 feet, and the other, the Bohemian Range, just west of Portage Bay, includes peaks 2,500 feet in elevation. The southern end of the island consists of low-lying hills rarely exceeding 1,000 feet in altitude. A low pass from the head of Duncan Canal to Portage Bay nearly separates the eastern from the western half of the island.

Kupreanof is separated from Kuiu Island by Keku Strait, an irregular tide-water passage, through which only small boats can pass. Kuiu Island is deeply dissected by bays, which almost divide it and.give it an extremely irregular shore line. At the head of Bay 


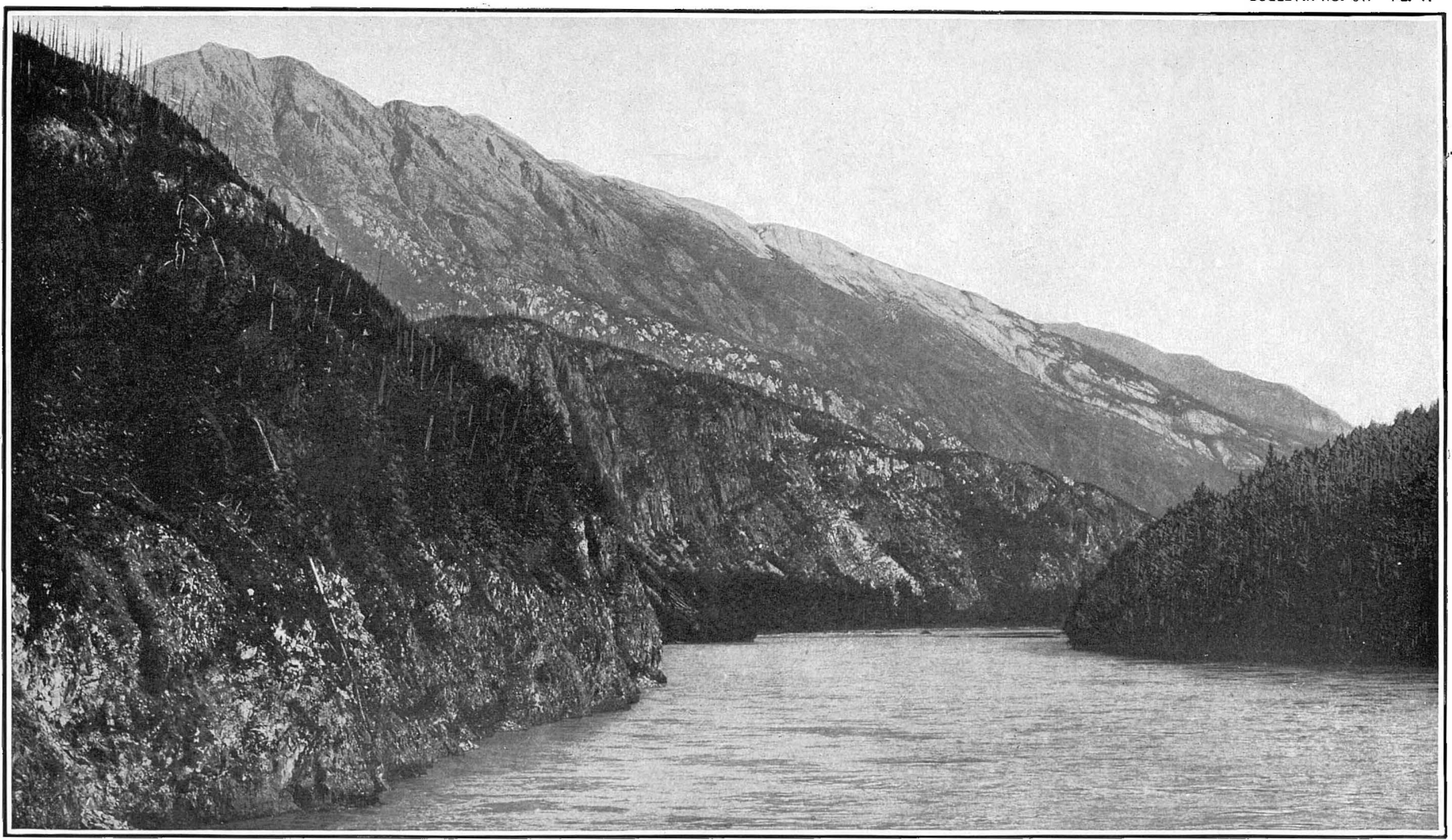

KLOOCHMAN CANYON, STIKINE RIVER.

View northeast toward the eastern contact of the Coast Range intrusives. In the distance is a black band of argillites dipping away from the granite intrusive and overlain by a white band of limestone. 

of Pillars is a portage 1 mile in length, which connects with Port Camden on the east side of the island. Another low pass extends from the head of Port Camden to Threemile Arm on the southeast side of the island. Small mountainous areas were noted on the west coast of Kuiu Island east of Washington Bay and on the two peninsulas forming the south end of the island. Few of the highest peaks exceed 2,500 feet in elevation, and the mountain summits are generally less than 2,000 feet.

In general both the course of the valleys and the trend of the small mountain ranges of these outer islands conform to the underlying rock structure, which has largely controlled the erosive processes. The intrusive masses and upturned edges of resistant. schists and limestones persist above the general level and form the hills, ridges, and mountain peaks. The areas of soft shales, sandstones, and less resistant rocks are marked by lowlands, deep valleys, and channels.

No glaciers or ice fields are now on these islands, but evidence of former glaciation is everywhere present. On Prince of Wales Island basins scooped by glacial action and now filled with lakes occur at elevations of 600 to 2,000 feet in the vicinity of Copper Mountain, and the surrounding mountains, composed essentially of granite, are well rounded and have on them many large bowlders which are evidently erratics. In the Klawak Range to the north are several clearly defined glacial cirques containing small lakes and surrounded by more or less jagged crest lines. In the rock exposures along the tide-water channels grooves were observed in a few places which may also be attributed to glaciation. Similar phenomena were noted on Kuiu and Kupreanof islands.

The coast line of these islands is broken by bays, coves, and channels. The hydrographic maps of this area show numerous excellent harbors and many. protected channels which favor navigation. One of the striking features is the shallowness of many of the bays and channels as compared with the depths noted in the fiords of the mainland belt. Again, the river deposits at the heads of bays have a gradual slope and do not descend abruptly into deep water a short distance from the shore, as do the tide flats along the mainland. These facts and the topographic observations tend to show the greater advance in topographic development of the seaward portion in contrast with that of the mainland. (Compare $\mathrm{Pl}$. V, A, with Pl. V, B.)

\section{CLIMATIC CONDITIONS.}

The annual changes in climatic conditions in southeastern Alaska are not so varied as might be expected for a region lying between $55^{\circ}$ and $60^{\circ}$ north latitude. The effect of the warm ocean current of the northern Pacific is strongly felt and serves to moderate the climate. 
This region is characterized by mild winters and cool summers, and by heavy precipitation, which is greatest at the points exposed to the sea and diminishes somewhat inland. Nearly all the precipitation below an elevation of 500 feet is in the form of rain. Most of the rain falls between the first of September and the last of January, though the amount varies greatly from one year to another. The season of least rainfall is generally from April to July.

The prevailing winds come from the southwest, and bear humid atmosphere from the sea, which gathers about the mountain range and condenses in the form of fog and rain. This causes excessive rainfall along the western slopes of the Coast Range, while the inland regions to the east suffer for want of the rains thus intercepted. A change from a southwest to a north wind almost invariably brings fair weather.

The temperature throughout the year is mild, the thermometer rarely falling to zero Fahrenheit at the lower elevations. The snowfall is heavy in the mountains, from 3 to 8 feet in depth, but near sea level not more than a few inches of snow fall at one time during an ordinary winter and this soon disappears.

Two tables from a report on the meteorology compiled by Cleveland Abbe, jr., ${ }^{a}$ follow, one presenting the average rainfall per month in inches at different points along the coast, the numbers representing the mean precipitation for two or more years; the other giving the average maximum and minimum temperature in degrees Fahrenheit for each month, as recorded at the different stations for periods of several years. A third table, compiled by Alfred H. Brooks, is added for the purpose of comparison. It gives the average monthly temperatures at various stations in southeastern Alaska and at foreign localities of about the same latitude. The data from the station at Port Angeles in Washington is included with the others to show the slight difference that exists between the average monthly temperature in southeastern Alaska and that of the portion of Washington adjacent to the coast.

Average monthly precipitation in southeastern Alaska.

[In inches.]

\begin{tabular}{|c|c|c|c|c|c|c|c|c|c|c|c|c|c|}
\hline Station. & Jan. & Feb. & Mar. & Apr. & May. & June. & July. & Aug. & Sept. & Oct. & Nov. & Dec. & Total. \\
\hline $\begin{array}{l}\text { Wrangell- } \\
\text { Killisnoo-. } \\
\text { Juneau. } \\
\text { Skagway } \\
\text { Sitka }\end{array}$ & $\begin{array}{r}6.07 \\
5.98 \\
8.77 \\
.90 \\
12.17\end{array}$ & $\begin{array}{l}8.11 \\
4.96 \\
4.38 \\
.57 \\
7.47\end{array}$ & $\begin{array}{l}2.89 \\
4.04 \\
4.62 \\
.64 \\
6.70\end{array}$ & $\begin{array}{l}4.11 \\
3.50 \\
7.04 \\
2.39 \\
5.61\end{array}$ & $\begin{array}{l}3.71 \\
3.58 \\
4.28 \\
.77 \\
4.11\end{array}$ & \begin{tabular}{r|}
3.56 \\
2.36 \\
3.09 \\
.60 \\
3.31
\end{tabular} & $\begin{array}{l}3.69 \\
4.19 \\
3.96 \\
1.73 \\
3.55\end{array}$ & $\begin{array}{l}3.07 \\
4.90 \\
9.39 \\
1.51 \\
5.84\end{array}$ & $\begin{array}{r}6.63 \\
7.79 \\
11.39 \\
3.47 \\
9.67\end{array}$ & $\begin{array}{r}7.36 \\
7.92 \\
11.47 \\
3.22 \\
11.96\end{array}$ & $\begin{array}{r}11.27 \\
5.16 \\
7.51 \\
3.22 \\
9.80\end{array}$ & $\begin{array}{r}10.41 \\
4.81 \\
8.37 \\
3.78 \\
7.88\end{array}$ & $\begin{array}{l}70.88 \\
58.97 \\
84.27 \\
21.75 \\
88.10\end{array}$ \\
\hline
\end{tabular}

a Prof. Paper U. S. Geol. Survey No. 45, 1906, pp. 158-167. 
Monthly maximum and minimum temperatures in southeastern Alaska.

[In degrees Fahrenheit.]

\begin{tabular}{|c|c|c|c|c|c|c|c|c|c|c|c|c|}
\hline Station & \multicolumn{2}{|c|}{ Jan. } & \multicolumn{2}{|c|}{ Treb. } & \multicolumn{2}{|c|}{ Mar. } & \multicolumn{2}{|c|}{ Apr. } & \multicolumn{2}{|c|}{ May. } & \multicolumn{2}{|c|}{ June. } \\
\hline $\begin{array}{l}\text { Wrangell. } \\
\text { Killisnoo } \\
\text { Juneau } \\
\text { Skagway } \\
\text { Sitka }\end{array}$ & $\begin{array}{l}47 \\
52 \\
44 \\
42 \\
51\end{array}$ & $\begin{array}{r}-4 \\
-2 \\
4 \\
-4 \\
-2\end{array}$ & $\begin{array}{l}58 \\
50 \\
50 \\
44 \\
54\end{array}$ & $\begin{array}{r}2 \\
-10 \\
-\quad 9 \\
-3\end{array}$ & $\begin{array}{l}54 \\
52 \\
61 \\
63 \\
65\end{array}$ & $\begin{array}{l}-10 \\
-2 \\
-5 \\
-10 \\
-1\end{array}$ & $\begin{array}{l}64 \\
63 \\
61 \\
61 \\
70\end{array}$ & $\begin{array}{l}24 \\
15 \\
28 \\
16 \\
19\end{array}$ & $\begin{array}{l}78 \\
76 \\
69 \\
79 \\
80\end{array}$ & $\begin{array}{l}38 \\
24 \\
29 \\
25 \\
28\end{array}$ & $\begin{array}{l}86 \\
76 \\
80 \\
90 \\
80\end{array}$ & $\begin{array}{l}38 \\
33 \\
36 \\
31 \\
33\end{array}$ \\
\hline Station. & Jul & & $\mathrm{Au}$ & $\mathrm{g}$. & Se & pt. & Oct & & No & & Dec & \\
\hline $\begin{array}{l}\text { Wrangell } \\
\text { Killisnoo } \\
\text { Juneau. } \\
\text { Skagway } \\
\text { Sitka_ }\end{array}$ & $\begin{array}{l}82 \\
84 \\
86 \\
92 \\
87\end{array}$ & $\begin{array}{l}44 \\
38 \\
40 \\
39 \\
35\end{array}$ & $\begin{array}{l}84 \\
81 \\
71 \\
80 \\
82\end{array}$ & $\begin{array}{l}43 \\
36 \\
39 \\
32 \\
39\end{array}$ & $\begin{array}{l}73 \\
69 \\
65 \\
76 \\
74\end{array}$ & $\begin{array}{l}38 \\
27 \\
34 \\
30 \\
32\end{array}$ & $\begin{array}{l}67 \\
60 \\
65 \\
60 \\
65\end{array}$ & $\begin{array}{l}31 \\
25 \\
23 \\
16 \\
25\end{array}$ & $\begin{array}{l}53 \\
53 \\
56 \\
51 \\
59\end{array}$ & $\begin{array}{r}4 \\
1 \\
10 \\
7 \\
5\end{array}$ & $\begin{array}{l}52 \\
54 \\
54 \\
57 \\
59\end{array}$ & $\begin{array}{r}-3 \\
1 \\
8 \\
-4 \\
7\end{array}$ \\
\hline
\end{tabular}

Mean monthly temperatures for stations in southeastern Alaska and for foreign localities near the same latitude. ${ }^{a}$

[In degrees Fahrenheit.]

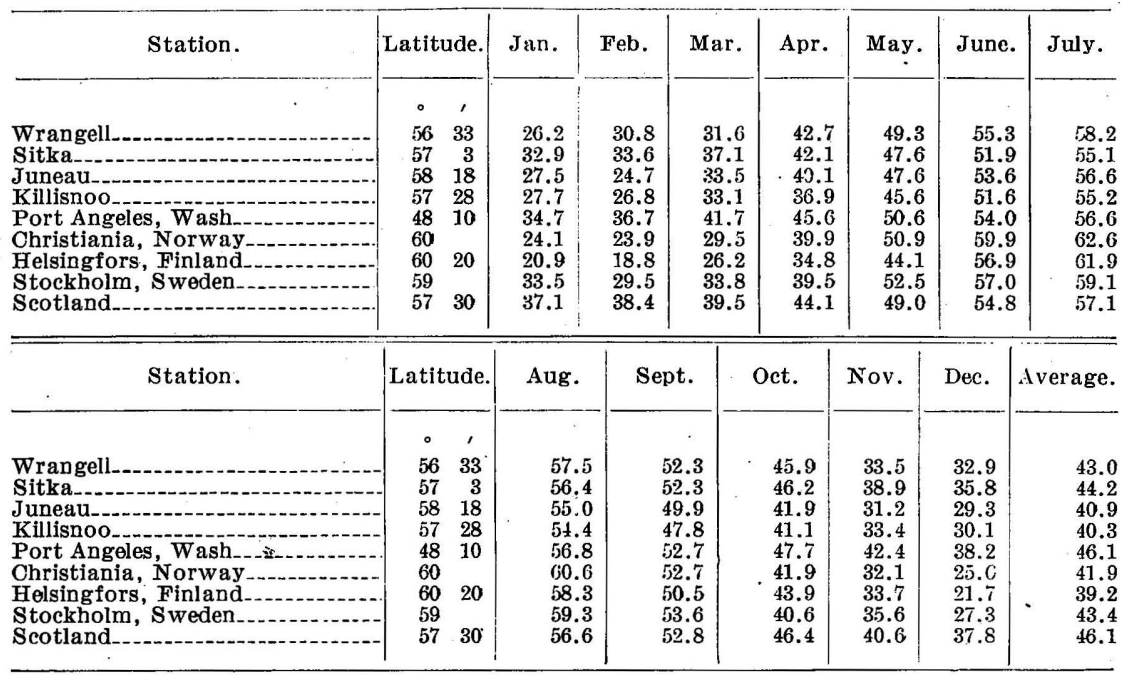

a Compiled by Alfred $H$. Brooks from the following publications: $U$. S. Weather Bureau reports; Landrugsdirekt, Beretning, 1893; Pfver, Finska Vetenskaps Soc. Forhandlinger; Meteror Iaktag. i Sverige k. Svensk Vetens. Akad., 1890; Trans. Highland and Agric. Soc. Scotland, 1895.

These tables show that climatic conditions in the Ketchikan and Wrangell districts are favorable for the development of mining enterprises. The abundant precipitation is rather trying to those who are accustomed to a more arid climate, but this rainfall, though a drawback to the prospector, does not interfere with mining developments. In fact, it is an advantage, as it furnishes considerable water power which can be utilized in mining operations. Except at high altitudes, snow does not interfere materially with transportation or mining. 


\section{TIMBER AND VEGETATION.}

\section{DISTRIBUTION OF TIMBER. ${ }^{a}$}

Southeastern Alaska is mostly forested, but the portion covered with a commercial stand (marketable timber) is relatively small. The greater part is included in the Alexander Archipelago National Forest.

The forests of the region are made up of the coniferous species shown in the following list, which presents also an estimate of the approximate quantity of each:

\section{Trees of southeastern Alaska.}

Per cent.

Western hemlock, Tsuga heterophylla 60 to 70

Sitka spruce, Picea sitchensis 20 to $2 \pi$

Yellow cedar, Chamœcyparis nootkaensis.

Red cedar, Thuya plicata

Alpine hemlock, Tsuga mertensiara

Jack pine, Pinus contorta

The amount of timber in the stands of commercial forests varies greatly, ranging from 30,000 to 80,000 feet (board measure) per acre. The average stand of saw timber along this coast, however, is much less, probably not more than 5,000 to 10,000 feet per acre, because of the wide intervals of poor forest growth in the swampy areas and on the higher slopes.

Except on the limited areas of alluvial deposits along the streams, the logging conditions are not good, the best timber being on steep or rough ground.

Although the hemlock is the dominant tree and the best timber for general purposes, it is little used for saw timber because of a public prejudice against it. Loggers often object cause its excessive weight adds to the difficulty of towing. It is used at present chiefly for piling, for which it is well adapted if cut during the winter months, when the bark is close and not so susceptible to the attacks of the ship worm (Toredo navalis). The tree of greatest present commercial value is the spruce, which is used for all purposes. Its soft, fibrous wood has little shearing strength and is not serviceable for ore bunkers, bins, or other structures requiring great strength. Many spruce trees have magnificent proportions, and the average yield of lumber for each tree is from 3,000 to 4,000 feet.

The supply of standard spruce logs available by beach hand logging has now nearly been exhausted, so that the use of hemlock is increasing and mine operators are getting a stronger, better timber.

${ }^{a}$ For the notes on distribution and value of timber in southeastern Alaska the writers are indebted to Mr. W. A. Langille, forest supervisor at Ketchikan, Alaska. 
The red cedar, being near its northern limit of growth, is not of the best quality, and the hand loggers do not go far enough inland to obtain the best growth. It is therefore little used except for boat building.

Yellow cedar of good quality occurs too far inland and at altitudes too high above sea level to be obtained by the present methods of logging. Trees of good size and fairly clear are found, yielding an excellent finish material susceptible of a high polish, but there is little demand for it in this region.

\section{VALUE OF TIMBER.}

The abundance of the timber supply of Washington and Oregon and its nearness to comparatively inexpensive means of transportation precludes for some time the probability of considerable demand for the timber of this region.

The present low price of lumber of the quality used in southeastern Alaska renders competition between the two regions impossible except for local requirements. Logging operations are successful close to tide water, where the position of the timber permits easy transportation. The requirements necessarily imposed on timber cutting within the reserves, by which only a certain percentage of the forest may be removed, the care necessary to avoid injury to the remaining trees, and the expense involved in disposing of tops and litter so increase the cost that logging on a large scale with the view of shipping from Alaska appears at present unprofitable.

In southeastern Alaska as a whole the quantity of first-class timber is limited, though the region possesses many million feet of an inferior grade, suitable for rough material and pulp wood, which may some day be a considerable resource.

\section{GROWTH OF VEGETATION.}

The luxuriant growth of vegetation along the coast of southeastern Alaska may well be compared with that of a tropical region. This is caused by the moist and temperate climate and the long summer days at this high altitude. At elevations below 1,500 feet bushes, ferns, and tall grasses grow profusely, especially in the valleys and gulches. These form in places a dense and almost impassable undergrowth and are a great hindrance to the prospector. Among the most common of these shrubs are the thorny devil's club, the salmon berry, the elderberry, the huckleberry, the high bush cranberry, various willows, the black alder, and the white alder, the latter forming thickets along the streams and mud flats. 


\section{THE NATIONAL FOREST.}

The Government has wisely added several of the large islands, namely Prince of Wales, Kuiu, Kupreanof, Zarembo, and Chichagof islands of the Alexander Archipelago, to its national forest, thereby insuring intelligent use of the timber for the present and preservation and protection for future demands. Though the establishment of the new Alexander Archipelago National Forest appears to many in Alaska to have placed a restraint on the prospector and mine owner, yet the provisions of the law in regard to mining within the reservation are liberal. The following extracts from the "Use Book" relate to the Alaskan national forests:

Reg. 36. Trails on national forest lands in Alaska may be constructed, extended, or repaired without permit. Wagon roads may be constructed, widened, extended, or repaired when needed, but permit must first be obtained from the supervisor. Permits will not give any right to the exclusive use, or to charge toll, or against future disposal of the land by the United States.

REG. 37. When a right of way or other special use is granted within a national forest in Alaska, the supervisor may, without charge, allow the cutting of timber when this is necessary for the proper enjoyment of the special use.

REG. 38. Without permit, and free of charge, settlers, farmers, prospectors, fishermen, or similar persons residing within or adjacent to national forests in Alaska are granted the privilege of taking green or dry timber from the forests, and driftwood, afloat or on the beaches, for their own personal use, but not for sale; provided that the amount of material so taken shall not in any one year exceed 20,000 feet board measure, or 25 cords of wood; and provided further, that the persons enjoying this privilege will, on demand, forward to the supervisor a statement of the quality of the material so taken and a description of the section from which it was removed.

It is also to be noted that timber cut from the national forest in Alaska may be exported from the district and sold in any market anywhere, upon certification by the supervisor that the timber has been purchased and cut from the national forest in Alaska. The exportation of timber from all areas in Alaska not included in the forest reserve is prohibited by law.

\section{GENERAL GEOLOGY OF SOUTHEASTERN ALASKA}

\section{GENERAL STATEMENT.}

The geologic distribution of the rocks along the southeast coast of Alaska is on a broad scale, and in their strike they follow the general northwest trend of the mountain range. These rocks may be divided into two main groups: (1) Stratified rocks, and (2) intrusive rocks, both having about the same areal extent.

The term "stratified rocks" has been used to include those formed (1) by sedimentation, such as shales, sandstones, conglomerates; (2) by precipitation and sedimentation, as limestones and cherts, and (3) by volcanic activity, as the lava and tuff beds. These beds occur 
interstratified with one another and, except the more recently formed rocks, are generally intricately folded and usually show a high degree of metamorphism. In this altered state they are represented by black slates, crystalline schists, graywackes, crystalline limestones, quartzites, and chlorite and amphibole schists.

The intrusive rocks are made up of a complex of coarse granular rocks, mostly granitic in character. They form the great mass of the Coast Range bordering the mainland, and occupy wide areas in the central portions of many of the islands. Their mode of occurrence is at many places directly related to the geologic structure, and their longitudinal axes and lines of contact are usually parallel with the strike of the bedded rocks.

\section{STRATIGRAPHIC' SUCCESSION.}

The geologic succession of the stratified rocks in southeastern Alaska is complex, and includes rock formations representing nearly all the geologic periods from early Paleozoic to the present. Though the rocks have been mapped only in a broad way, the sequence of the formations has been sufficiently well established to permit grouping them according to age. The stratigraphic succession is presented in the table on pages 34,35 , and in this an attempt has been made to show not only the general order of rock deposition but the relations of the strata of the different periods, so far as known, and their structural characteristics.

40840-Bull. 347-08-3 


\begin{tabular}{|c|c|c|c|c|}
\hline Age. & $\begin{array}{c}\text { Thickness } \\
\text { (feet). }\end{array}$ & Character of rocks. & Structural characteristics. & Localities of occurrence. \\
\hline Recent... & $500 \pm$ & Basaltic lavas, tuffs.. & Flat lying, undulating. & $\begin{array}{l}\text { Mount Edgecumbe, mainland, } \\
\text { Ketchikan district. }\end{array}$ \\
\hline Pleistocene... & (?) & Gravel bench deposits interstratified with clayey beds carrying marine shells. & & $\begin{array}{l}\text { Douglas Island, Funter Bay, } \\
\text { Port Snettisham. }\end{array}$ \\
\hline Pliocene. & $1,000 \pm$ & $\begin{array}{l}\text { Conglomerates, sandstones, shales, coal seams, containing marine shells and } \\
\text { fossil plants. }\end{array}$ & $\begin{array}{l}\text { Faulted and tilted at low } \\
\text { angles. }\end{array}$ & Lituya Bay, Icy Point. \\
\hline Eocene & $1,500 \pm$ & $\begin{array}{l}\text { Basalts, andesites, rhyolite tuffs, breccias, conglomerates, sandstones, and } \\
\text { coal seams, with fossil plants. } \\
\text { Conformity. }\end{array}$ & $\begin{array}{l}\text { Flat lying, slightly tilted, } \\
\text { covering wide areas. }\end{array}$ & $\begin{array}{l}\text { South end Kupreanof Island, } \\
\text { Port Camden, Hamilton } \\
\text { Bay, Murder Cove, Kootz- }\end{array}$ \\
\hline Cretaceous. & $1,000+$ & Conglomerates, sandstone, shale, and coal seams, with fossil plants & $\begin{array}{l}\text { Tilted, slightly folded, un- } \\
\text { metamorphosed, occupying } \\
\text { local basins. }\end{array}$ & \\
\hline $\begin{array}{l}\text { Lower Cretaceous to } \\
\text { Jurassic. }\end{array}$ & $500+$ & $\begin{array}{l}\text { Shale, conglomerate, and black limestone wi } \\
\text { Gray limestone, A ucella beds....................... }\end{array}$ & $\begin{array}{l}\text { Folded and faulted, with } \\
\text { steep dips and variable } \\
\text { strikes, slightly metamor- } \\
\text { phosed, occurrence local. } \\
\text { Same as above. }\end{array}$ & Pybus Bay, Admiralty Island. \\
\hline & $2,000 \pm$ & $\begin{array}{l}\text { Graywackes, slates, and conglomerates, carrying granite cobbles; lava con- } \\
\text { glomerates, and sandstones; no fossils. } \\
\text { Conformity. }\end{array}$ & $\begin{array}{l}\text { Folded and faulted, indu- } \\
\text { rated, variable strike and } \\
\text { dip, distribution limited. } \\
\quad \text { : }\end{array}$ & $\begin{array}{l}\text { San Fernando Island, west } \\
\text { coast of Prince of Wales, } \\
\text { Uolla Channel. }\end{array}$ \\
\hline Triassic........... & $1,000 \pm$ & $\begin{array}{l}\text { Andesitic lavas, tuffs, breccia, conglomerate, and sandstone overlying } \\
\text { granite intrusives; no fossils. } \\
\text { Gray argillaceous limestone, fossiliferous, calcareous sandstone, con- } \\
\text { glomerate. }\end{array}$ & $\begin{array}{l}\text { Steeply tilted and folded with } \\
\text { ge n e r a l northwesterly } \\
\text { strike and variable dip, } \\
\text { metamorphosed and ren- } \\
\text { dered slightly schistose; } \\
\text { distribution limited. } \\
\text { (?) }\end{array}$ & $\begin{array}{l}\text { South end Prince of Wales } \\
\text { Island, Klakas Inlet. }\end{array}$ \\
\hline & $1,000 \pm$ & Cherty limestone breceia and conglomerate, carrying fossils.................... & $\begin{array}{l}\text { Steeply tilted and folded, me- } \\
\text { tamorphosed. }\end{array}$ & $\begin{array}{l}\text { Hamilton Bay, Screen Islands, } \\
\text { Pybus Bay. }\end{array}$ \\
\hline $\begin{array}{l}\text { Permian (upper } \\
\text { Carboniferous). }\end{array}$ & $800+$ & 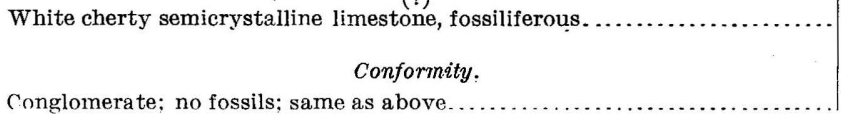 & $\begin{array}{l}\text { Strike variable, steeply tilted, } \\
\text { broadly folded, metamor- } \\
\text { phosed. }\end{array}$ & $\begin{array}{l}\text { Pybus Bay, Herring Bay, } \\
\text { Screen Islands, Pybus Bay. }\end{array}$ \\
\hline
\end{tabular}




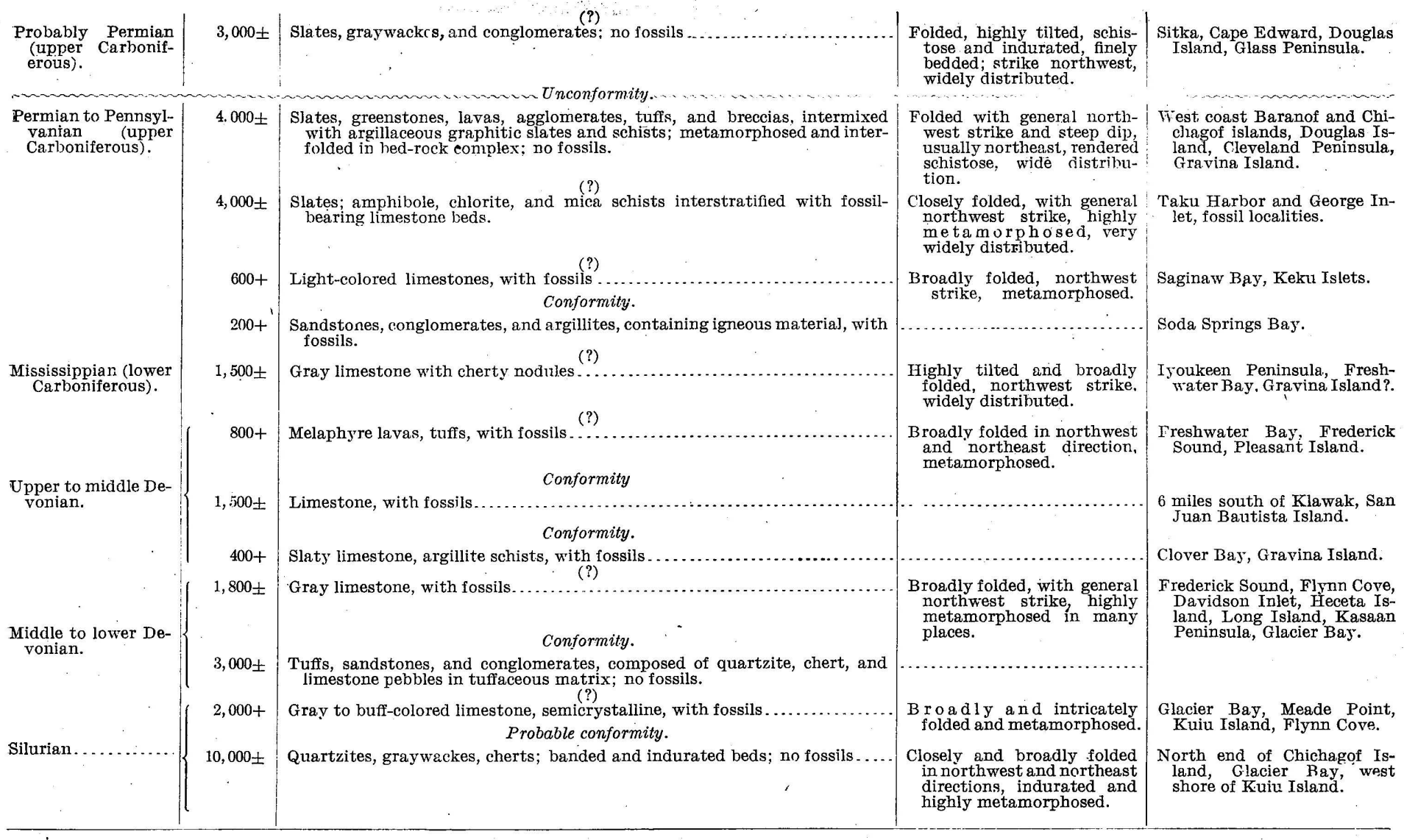


Many of the rocks grouped under the periods indicated in the stratigraphic column are synchronous with the formations represented along the Alaskan coast farther west and with those along the mainland and islands of British Columbia to the south. Correlation based on paleontologic evidence may also be made with the fossilbearing strata in the States of Washington, Oregon, and California and with the formations in other parts of Alaska and in Canada. These comparisons, however, have been reserved for a future report.

\section{ROCK FORMATIONS.}

Along this portion of the Alaskan coast the distribution of the rock formations is known in only a general way. The geologic observations have necessarily been confined to the rock exposures along the coast of the mainland and islands, and the inland portions of many of the larger islands remain unexplored. The peculiar alignment along the mainland of the formations which are parallel to the Coast Range intrusives, and the many inland waterways which cut across: these formations have greatly aided the general geologic reconnaissance of this region.

The dominant feature of the mainland, both structurally and petrographically, is the immense batholithic core of granite and diorite which occupies the central portion of the Coast Range throughout its length. The occurrence of this rock to the south in British Columbia, where conditions similar to those that prevail along the Alaskan coast are presented, has been discussed in detail by George M. Dawson. Brooks, in his report on the Ketchikan mining district, also gives it careful consideration, and Spencer in his report on the Juneau gold belt describes the occurrence of this intrusive rock and its relations to the intruded strata and to the ore deposits. ${ }^{a}$ From Portland Canal north to Lynn Canal its western contact parallels the main coastwise channels. Just north of Berners Bay it crosses Lynn Canal, and its western contact extends north along the east side of Chilkat Valley.

Bordering this intrusive core of the Coast Range is a band of closely folded crystalline schists composed largely of Carboniferous strata and in places having a width of several miles. In this province these rocks were termed the Ketchikan series by Brooks, ${ }^{b}$ and in the Junear district the corresponding rocks are grouped together as the "Schist band" by Spencer. ${ }^{c}$ These crystalline schists have been traced from the southern boundary of Alaska to the head of the Chilkat basin at the British Columbia boundary. The strata are essen-

a The Coast Range intrusives and their bearings on the ore deposition are considered at length on pp. 61-69 of this report.

${ }^{b}$ Brooks, A. H., Ketchikan mining district: Prof. Paper U. S. Geol. Survey No. 1, 1902.

- Spencer, A. C., 'The Juneau gold belt: Bull. U. S. Geol. Survey No. 287, 1906. 
tially siliceous mica schists, feldspathic schists with intercalated amphibole and chlorite schists, and occasional beds of crystalline limestone containing Carboniferous fossils. Narrow outlying belts of the Coast Range intrusives invade these schists, and near the contacts with these as well as with the main mass the schists are cut by a network of pegmatite dikes and quartz veinlets. In places the alteration of the beds has been so intense as to produce gneiss, which near the intrusive contact has been thoroughly recrystallized and rendered massive, so that it is not everywhere possible to distinguish with certainty the line of contact between the intrusive and bedded rocks. .

To the southwest the beds become less schistose, and "black slates," intruded by altered dikes of andesitic and gabroic rocks, predominate. The latter are more prominent along the mainland in the Juneau district than to the south. Intercalated beds of altered lavas and tuffis, usually called greenstones, gradually find place in the slate belt, and farther southwest great thicknesses of these greenstones occur. Such a belt of massive greenstone beds is well exposed at the following places: The shores of Tongass Narrows at Ketchikan, the west end of Cleveland Peninsula, Woewodski Island in Duncan Canal, Cape Fanshaw, Glass Peninsula, and the west side of Douglas Island.

Beyond this belt toward the outer coast the geologic section and bed-rock structure across southeastern Alaska change with the latitude, and beds of one formation can not be traced for any great distance northwesterly as can the rocks along the mainland. This is largely due to the irregular batholithic intrusives which occupy the central portions of most of the islands and are similar in composition to the Coast Range granite. Since detailed descriptions of the areal geology and sections across the Ketchikan and Wrangell districts follow, it is necessary to add here, for the purpose of comparison, only a short discussion of the rock occurrences on the northernmost islands of the archipelago.

On Admiralty Island the underlying stratified rocks are broadly folded limestones and schists, mainly of early Carboniferous age. At both Pybus Bay and Herring Bay collections of upper Carboniferous fossils were made. At the entrance to Pybus Bay lower Cretaceous fossils were gathered from calcareous shales which overlie the Carboniferous beds uncomformably. The basin of Kootznahoo Inlet is occupied by a considerable thickness of sandstones and conglomerate beds containing coal seams with fossil plants of Eocene age. The basalt lava flows which cover the southern end of the island southeast of Pybus Bay represent the most recently formed rocks. Invading all of the stratified rocks of Paleozoic age are irregular granite masses occupying small areas. 
The geology of the two seaward islands, Baranof and Chichagof, also presents many interesting features. The central portions of the islands are made up of granitic intrusives forming broad belts that strike across the islands in a northwesterly direction and invade all the bedded rocks except the recent lavas. The mineral deposits are located near the contacts with these granite masses. The oldest rocks are strata of banded quartzite resembling graywacke and chert in places. These beds are exposed for several miles along the north shore of Chichagof Island between Idaho Inlet and Frederick Sound, where they form a large anticline striking northwest. To the west they are invaded by a wide belt of granite, which has altered them to a compact biotite schist. Along the northeast shore from Frederick Sound to Point Augusta they again form the shore outcrops. - Though the thickness of this formation could not be determined, it probably represents many thousands of feet of sedimentation. Overlying the quartzites are cherty limestones in which middle Devonian fossils were found in Frederick Sound and on the south side of Freshwater Bay.

The upper Devonian formation is represented by melaphyre lavil flows and tufaceous beds; fossils were collected from the latter along the west shore of Frederick Sound. These beds extend southeasterly into Freshwater Bay. Limestone of considerable thickness overlie; the melaphyres and is exposed in Frederick Sound and along the northeast shore of Freshwater Bay. At these places large collections of lower Carboniferous fossils were obtained. West of the granitic core on the seaward shores of both Chichagof and Baranof islands is a series of crystalline schists and limestones, overlain by a belt of slates and greenstones of upper Carboniferous age. The latter in turn are overlain unconformably by a wide belt of considerably metamorphosed graywackes and conglomerates, which are prominent in the vicinity of Sitka and Point Edward. A remarkable analogy exists between this section and the cross section of the mainland belt in the vicinity of Juneau. The most recent rock formations on the seaward islands are the postglacial basaltic lava flows on Kruzof Island.

\section{STRUCTURE.}

The structural characteristics of the stratified rocks of the different geologic horizons in southeastern Alaska are noted in the table on page 34 and in the geologic section accompanying each geologic map. However, a formation may be intricately folded and highly metamorphosed at one locality, but at another it may be characterized by broad folds and a much less amount of metamorphism, so that in such a table it is possible to present only the more typical structural features. A brief consideration of these structural phenomena and their relations to the geologic history is therefore necessary. 
By a consideration of the entire coastal province of southeastern Alaska, several important features which throw light on the dynamic history of the region are brought out. In the Ketchikan and Wrangell districts alone these features are not so clearly marked. Prior to the development of the main northwest-trending structural lines, which at present dominate this coastal province and are most pronounced adjacent to the wide areas of intrusive rocks, the prevalent structure was made up of northeasterly trending folds. These folds still form a minor system prominent on Chichagof, Admiralty, and Prince of Wales Island. The later and more intense folding of the beds on a broader scale, which forms the major system and trends northwesterly, has in general obliterated this minor system. But the evidence of the two systems is clearly presented on the north shore of Chichagof Island, where the minor system of small folds is the dominant structure at those places which are distant from the northwesttrending intrusive belts and which are not greatly disturbed and metamorphosed. Nearer the intrusive belts the larger system gradually prevails, and the minor folds as a whole are combined in the broader anticlines and synclines of the major northwest-trending folds. Complex minor folding and fracturing is thus produced in the beds. The fact that beds of upper Carboniferous age have this northeasterly folding indicates that this was the dominant bed-rock structure at the close of the Paleozoic era. Whether the younger system of folding was produced just previous to the intrusion of the Coast Range granite, or at the time of its invasion, has not been definitely established, though, as suggested by Spencer, ${ }^{a}$ it was probably before the invasion of these igneous rocks, as the planes of contact, with few exceptions, follow the planes of bedding, and to present this structure the strata must have been highly tilted and must have occupied a position similar to that which they now have. Along the mainland, across a width of from 5 to 10 miles, the uniformity of the strike and dip of the stratified rocks adjacent to the Coast Range granite indicates a monoclinal structure. Such interpretation, however, would necessitate a still greater thickness of the rock beds at the time of their deposition, as in their present condition they are greatly compressed and metamorphosed. From the evidence of broad folding of the beds, believed to be the same, which are exposed along the west shore of Admiralty Island, it is reasonable to assume that this rock belt has the structure of a closely folded and compressed synclinorium, and that the tops of the anticlines were subsequently removed, leaving little or no definite proof of their existence.

After this great period of mountain building, which is believed to have occurred about the close of Paleozoic or in early Mesozoic time, further important orogenic movements of the earth's crust took place

“ Spencer, A. C., The Juneau gold belt: Bull. U. S. Geol. Survey No. 287, 1906, p. 14. 
and are clearly shown in the Mesozoic beds on Admiralty and Prince of Wales islands. The Aucella beds on Admiralty Island are steeply tilted and faulted and to some extent metamorphosed, but they do not show close folding or uniformity in direction of strike. On Prince of Wales Island beds, probably of Mesozoic age, though nonfossiliferous, overlie the granite intrusives; at certain localities they have assumed a steeply tilted position with northwesterly strike and are considerably metamorphosed, while at other places they are only slightly folded and show no persistent direction of strike or dip and but little metamorphism. The forces producing this later structure affected the older Paleozoic strata largely by faulting, fissuring, and tilting, and not by intense folding. The structural characteristics in the Tertiary (Eocene) beds and those of late Cretaceous age indicate tilting and faulting and there is little or no evidence of folding or metamorphic action. The effects appear to be confined largely to the basins or local areas occupied by these rocks, and in the older beds faults and fissures were probably produced along which the basaltic lavas subsequently found egress.

In addition to the preceding description of the different periods of dynamic revolution, the structurally significant faulting which accompanied these orogenic movements deserves special consideration. Evidence of these faults; however, is shown largely.by the local discontinuity of the strata, as surface indications have been removed by erosion. Moreover, those faults, possibly numerous, which are parallel to the bedding, are difficult to decipher, because of the extreme metamorphism of most of the rocks. Only the structurally important faults which show large displacement and the minor faults or slipping planes in the ore bodies and in shore exposures were noted.

The largest and most important fault plane in southeastern Alaska, which is suggested both geologically and topographically, extends from the head of Lynn Canal in a S. $10^{\circ}$ E. direction 200 miles or more through Chatham Strait into the Pacific Ocean. The displacement at its southern end is evidently greater than at the head of Lynn Canal, where the main fault appears to diverge into two or more directions indicated by Taiya Inlet, Ferebee River, and possibly Chilkoot Inlet and River. The displacement and the direction of throw of this fault are not clearly defined, though the former probably amounts to many miles.

Detailed work in this province will doubtless reveal many other taults that are structurally important. Minor faults and slipping planes noted in the ore bodies, stratigraphically of little significance, though economically of great importance, are discussed in the detailed descriptions of the ore bodies. 
MINERAL DEPOSITS.

Metallic mineralization in southeastern Alaska is confined to certain rock formations, and in these the mineral deposits occur to some extent along certain zones which have been more or less satisfactorily determined. Because of the rough topography and the dense growth of forest and underbrush, investigations of such belts have necessarily been limited to the vicinity of salt water, where the rock formations and mineral belts are clearly exposed.

The direct relation of mineralization, or the occurrence of ore, to the rock structure and to the intrusive rocks is at many places very evident, Most of the ore bodies are found near or, more rarely, in the larger intrusive masses, and especially in those places where the general rock structure trends northwesterly. In a broad way, the mineral deposits are coextensive with the areas of granitic intrusives and occur in the adjacent metamorphic rocks affected by such intrusives.

The most extensive and productive area is the Juneau gold belt, ${ }^{a}$ which has been irregularly traced along the mainland from Windham Bay to a point 10 miles north of Berners Bay, where it enters Lynn Canal. Its total length is 120 miles and its width less than 10 miles. In this zone gold is the dominant metal present and occurs in varying amounts disseminated with sulphide minerals in bands of schistose rock 10 to 60 feet wide, in altered diorite dikes, where it is associated with stringers of quartz, and in quartz veins, 1 to 10 feet wide, cutting either the intrusive or schistose country rock. The ore bodies within this zone are discussed at length by A. C. Spencer in his report on the Juneau gold belt.

In the Wrangell district the concentration of metallic minerals along definite zones has apparently not taken place, though a number of mineral prospects have been found, namely, in Thomas and Le Conte bays, along Bradfield Canal, and in Groundhog and Glacier basins. At the last two localities silver and lead ores, occurring in quartz veins inclosed in the crystalline schists, are prominent, while at the others gold is the dominant metal present. Within the mainland belt of the Ketchikan district, which includes Revillagigedo Island, quartz veins and mineralized schist bands are found locally, but they are too widely separated to permit the definition of a mineral zone like that in the Juneau district. The slates and greenstones contain the largest percentage of metallic minerals, and in them deposits have been developed on Gravina Island, along the west shore of Revillagigedo Island, and on Cleveland Peninsula. In the slates and schists nearer the Coast Range intrusives, vein deposits have been found at the head of Thorne Arm and in George Inlet. 
On the larger islands of southeastern Alaska the regularity of the rock structure and the continuity of the formations is locally interrupted by intrusive areas of granitic rocks and wide channels sejarating the islands. For this reason it is not possible to trace for any great distance mineral zones comparable with those along the mainland. The occurrence of the deposits on each island differs somewhat, and the islands are described separately in this paper. In general, the ore bodies appear to be closely connected with the intrusive rock masses, many of them lying at or near the contacts of the intrusives.

On Admiralty Island the areas of intrusive rocks, so far as known, are small, and the occurrence of valuable mineral deposits relatively rare. A poorly defined mineral zone starts at a point just north of Windfall Harbor on the west side of Seymour Canal and is traceable northwestward to Funter Bay. It is about 30 miles long and 2 miles wide and includes several prospects but no producing mines. Other prospects are located on the west coast of the island a few miles north of Kootznahoo Inlet.

On the two seaward islands, Baranof and Chichagof, which constitute the Sitka mining district, a poorly defined mineral zone occurs in the metamorphic schists flanking the west side of the intrusive belt, starting at Red Bluff Bay, on the east side of Baranof Island, and extending northwestward, including the prospects at the head of Silver Bay and in the vicinity of Cape Edward, north of which it enters the ocean. Auriferous vein deposits are the principal type of ore body in this mineral zone. Another zone of mineral-bèaring schists was noted along the eastern side of this intrusive belt extencling from Hooniah Sound to Lisianski Straits and northwestward on the mainland from Cape Spencer to Lituya Bay, where it flanks the St. Elias Range. Only a few prospects in the vicinity of Rodman Bay and at the head of Hooniah Sound have thus far been located in this mineral zone.

On Kupreanof Island scattered indications of a widespread mineral-bearing zone extend from the head of Portage Bay down the east side of Duncan Canal and include prospects along the wesst shore of Wrangell Narrows. The ore bodies thus far opened carry small values in both copper and gold. No deposits of ore have yet been discovered on Kuiu Island.

The distribution of mineral deposits on Prince of Wales Island, like that on the other islands, is dependent upon the intrusive areas. Here the direct relations of the ore bodies to the intr-ssive rocks are more evident because they occur in many places along the contacts of the intrusive and intruded rocks. Copper is the dominant metal in many of the deposits. It is present within the contact aureoles of the intrusive masses, as on Kasaan Peninsula and in the vicinity of 
Hetta Inlet, and occurs as lenticular masses or veins along shear zones in a greenstone schist country rock, as at Niblack and Copper City. Gold accompanies the copper deposits as an accessory constituent and is found in vein deposits inclosed in limestones at Dolomi and in black slates or phyllites in the vicinity of Hollis.

\section{GEOLOGY OF THE KETCHIKAN AND WRANGELL MINING DISTRICTS.}

\section{GEOLOGIC MAPS.}

Three geologic maps accompany this report (Pls. I, II, and III, in pocket); the first is a general geologic map on a scale of 10 miles to 1 inch and includes both the Ketchikan and Wrangell mining districts; the other two are of larger scale and show in greater detail the geology along the mainland portion of each district and the topography of this portion so far as it has been mapped. The general geologic map has been introduced to show the distribution of the two large rock types, the sedimentary and the igneous.

The sedimentary rocks, which are important to the geologist in deciphering the geologic history of a region, are subdivided into three groups separated by their differences in age. The oldest group-the Paleozoic strata-embraces a number of unconformable series which are much folded and in places highly metamorphosed. They are known to range in age from Silurian to upper Carboniferous and to have their most extensive development during the Carboniferous. A number of different formations belonging to this era have been recognized and distinguished one from the other at various localities, but, as their continuity and their lines of separation are only partially known, a differentiation of them has not been made on the map. The localities at which fossil evidence has been found are shown on the map by letters indicating the stratigraphic horizon represented. In the following pages these fossil localities are described and the known stratigraphic succession of the Paleozoic rocks is discussed.

The sediments of the Mesozoic era are represented only locally by interstratified slate, graywacke, and conglomerate beds of considerable thickness. These strata are often metamorphosed, indurated, and considerably folded, and in most places contain no fossils. Their classification is therefore based largely on structural and petrographic evidence. These rocks have been mapped as a unit but are considered at length in the following descriptions.

The Tertiary sediments are made up of shale, sandstone, and conglomerate occupying small areas which in places are coal-bearing. The unmetamorphosed and loosely consolidated state of these beds, the presence in them of numerous fossil plants, and the lack of in- 
tense folding are their principal characteristics. Paleontologic evidence shows these beds to be essentially of Eocene age, but at one point fossil plants of late Cretaceous age were identified.

The igneous rocks represented on the map fall into two classes, the intrusives and the extrusives, the latter being subdivided according to their composition and the period of extrusion. The areas of the intrusive rocks of this province are especially noteworthy because of their direct bearing on the occurrence of ore deposits. Their relations and the characteristics of the extrusive rocks are discussed in the following pages.

The two maps of larger scale, showing the eastern portions of the Ketchikan and Wrangell districts, have been introduced to show in greater detail the geology of the mainland belt and the topographic relief. These two maps and the map of the adjoining Juneau gold belt ${ }^{a}$ to the north form a continuous geologic and topographic sheet from Portland Canal to the head of Lynn Canal. All the sedimentary rocks indicated on the Juneau map are of Paleozoic age and occur in broad bands that have a general northwesterly trend and are traceable for nearly the entire length of the mainland belt.

Adjacent to the Coast Range intrusives and in places occupying small narrow areas within the intrusive belt is a succession of crystalline schists and limestone from 5 to 15 miles in width, composed largely of Carboniferous rocks. These in the Ketchikan district have been described as the " Ketchikan series," by Brooks, ${ }^{b}$ who also refers them to the Carboniferous. Spencer ${ }^{c}$ describes those to the northwest in the Juneau district as the "Schist band." To the southwest, across the trend, these rocks become less crystalline and this is indicated on the geologic map by the fewer dashes. Still farther southwestward black slate and argillites gradually dominate, and to the northwest they have been mapped as the "Slate belt" by Spencer. These slates bordering the coastwise channels are interstratified with volcanic tuffs and lava flows, which in turn dominate in amount over the sedimentary material and form the band mapped as greenstones. In the Juneau district the same succession of igneous and sedimentary rocks is present, and is described by Spencer as the "Slate-greenstone band." On the adjacent islands the areas mapped as "Undifferentiated Paleozoics" include slates, schists, limestones, and some conglomerates, which are either Carboniferous or Devonian in age. The fossil localities are indicated, as on the smaller scale map, by letters representing their stratigraphic horizon. The strata of crystalline limestone, mainly Carboniferous, which are important both stratigraphically and economically have been indicated sepa-

\footnotetext{
a Bull. U. S. Geol. Survey No. 287, 1906, Pl. XXXVII.

Brooks, A. H., Ketchikan mining district: Prof. Paper U. S. Geol. Survey No. 1, 1902, p. 42 .

- Spencer, A. C., The Juneau gold belt: Bull. U. S. Geol. Survey No. 287, 1906; p. 16.
} 
rately. The directions of both strike and dip of the structurally important rock beds are indicated, and the positions of the mines and prospects are shown.

Geologic sections transverse to the general direction of strike have been made for each of the three maps, and in them the known structural features are represented and are supplemented by more or less hypothetical dotted lines. The geologic maps and cross sections will be referred to in the following geologic descriptions, and the deseriptions should be considered together with the maps.

\section{SEDIMENTARY ROCKS.}

GENERAL STATEMENT.

The general sequence of geologic formations in southeastern Alaska as a whole is presented in tabular form on pages $34 ; 35$. This table applies to the Ketchikan and Wrangell districts, though in these districts all the formations noted have not been recognized. The distribution of the large subdivisions is shown on the geologic maps, and their relations are indicated to some extent in the geologic cross sections. Though the present geologic data of this province do not give a complete record of the different periods of rock deposition, the general succession has been fairly well established by structural and paleontologic evidence, and is discussed in the following pages in some detail.

Of the earliest rock formations little or nothing is known, and it is doubtful whether pre-Paleozoic strata are present in this province. The crystalline schists and gneissoid rocks, which form a wide band adjacent to the Coast Range and resemble the ancient metamorphic clastics of other regions, have been determined by paleontologic evidence $^{a}$ to be mostly of late Paleozoic age, and their present crystalline condition is attributed to metamorphism caused by the Coast Range intrusives.

\section{PALEOZOIC STRATA.}

SILURIAN.

The sedimentary record begins with the Silurian, which is represented by fossiliferous limestone strata. These overlie with apparent conformity a banded quartzite of great thickness, and the limestone and quartzite together form a belt, exposed at irregular intervals on the west coast of Prince of Wales and Kuiu islands, which extends northward and is again represented on Chichagof Island in Glacier Bay. Under the name "Wales series" Brooks ${ }^{b}$ included these older rock terranes. The banded quartzites are usually extremely fine 
grained or aphanitic, indurated, clastic rocks, gray to green in color, very brittle, and with no cleavage. They include both sedimentary strata and indurated beds of tuff intermixed with sedimentary material. Weathering usually produces a brown surface by the oxidation of pyrite and other ferruginous particles.

The Silurian limestones are best developed on the north side of Kuiu Island between Saginaw and Security bays. From the south side of Saginaw Bay a wide belt of cherty nonfossiliferous limestone strikes parallel to the shore with a northeasterly to vertical dip. This formation continues to a point one-half mile west of the entrance to the bay. At this point in the lower portion of the limestone belt fossiliferous beds were found by E. M. Kindle, who reports as follows:

Fauna. of the Meade Point limestone.-Fossils were found at but one locality in this limestone. They occur just east of the third cove northeast of Meade Point on the third point west of Saginaw Bay. The fauna contains a small number of species, but one of these, Conchidium knighti, is represented by very many shells in one thin bed of limestone. The fauna includes the following forms :

Diphyphyllum ? sp.

Conchidium knighti (Sow.).

Whitfieldella sp.

Holopea cf. servus Barr.

Murchisonio sp.

Conchidium knighti is one of the most characteristic fossils of the Aymestry limestone of the Ludlow group of England. It is known also from Russia and Bohemia. There appear to be no authentic records of its occurrence in the Silurian faunas of the United States. The fauna indicates a horizon of the upper part of the Silurian, but somewhat earlier than the Silurian fauna at Freshwater Bay or Chichagof Island.

Southwest of these fossiliferous limestones, on the opposite side of a small cove, banded quartzite beds underlie the limestones with apparent conformity and continue southwest with northwesterly strike and northeasterly dip, forming the bed rock of Security Bay. From Security Bay southward the quartzites are exposed along the entire western shore of Kuiu Island, a distance of nearly 50 miles, and are interrupted only locally at Washington Harbor and at the head of Pillar Bay by granitic intrusions. Along this entire coast no observations indicated that there was a duplication of these beds, but it is probable that duplication exists. The total thickness of the beds cannot, therefore, be estimated, though it must amount to many thousands of feet.

DEVONIAN.

At the base of the Devonian are conglomerates of considerable thickness, which contain pebbles and cobbles derived from the older Silurian beds. This fact suggests an unconformity between the Silurian and Devonian strata, though neither in the Ketchikan nor in the Wrangell districts were these two formations observed in contact with each other. 
Along the northwest shore of Prince of Wales Island and on the æmaller islands adjacent to Davidson Inlet limestone of considerable thickness at many points overlies these conglomerate beds, and together they represent the lowest horizon of the Devonian. These conglomerates consist essentially of cobbles of banded quartzite with some limestone and schist fragments. Toward the limestone beds they grade into sandstone and slaty limestone. They are conformably overlain by the limestone strata. Narrow beds of the sandstone also occur interstratified with the limestone beds. The limestones are semicrystalline and gray to blue in color, and not many of the fossil remains in them are preserved. At several points, however, imperfect fossil remains were gathered; the largest collection was obtained on the east shore of Heceta Island from beds directly overlying the conglomerates. Kindle reports as follows on this collection:

Cliff on east side of Heceta Istand.-The fauna from this locality includes Stropheodonta cf. comitans Barr., Gypidula ef. opatus, Atrypa reticularis, Pentamerus cf. procerulus, Atrypa ef. aspera, and several undetermined species.

The horizon is apparently lower Devonian. A fragmentary shell which seems to represent a finely plicated Conchidium indicates a horizon not later than early Devonian.

The total thickness of the conglomerate beds is estimated at 1,200 feet and that of the overlying limestone strata at 1,800 feet. At this locality the rock beds are broadly folded and considerably metamorphosed.

A somewhat higher horizon of the Devonian is represented by the fauna contained in the limestone beds on Long Island, in Kasaan Bay, on the east side of Prince of Wales Island. At this locality both lower and middle Devonian fauna have been recognized, though the limestone strata containing them are apparently conformable. The first fossils from this locality were gathered by Brooks ${ }^{a}$ in 1901, and were determined as middle Devonian by Prof. Charles Schuchert. In 1905 , E. M. Kindle made a more complete collection at this locality and submits the following report:

Blue limestones form much of the surface outcrops on a group of small, low islands near the middle of Kasaan Bay, of which Long Island is the largest. On Round Island the limestones are not greatly metamorphosed, but have occupied a zone of vigorous deformational activity. The island affords an uninterrupted outcrop of the limestones entirely around its shore line. These outcrops are of particular interest as illustrating in a small area the complex character of the deformation in this region. The beds are everywhere inclined at a high angle, usually about $90^{\circ}$. On the north and east sides of the island the strike is within a few degrees of due north. From nearly due north the strike swings around abruptly to $\mathrm{N} .80^{\circ} \mathrm{E}$. on the west side of the island. The exposures on the west side show the sharp elbow which the nearly vertical strata make in 
changing from a northerly to an easterly strike. The limestone on Round Island is shown by its fossils to be of the same age as the upper beds on Long Islaud, which lie a few hundred yards southeast.

On Long Island, which has a length of about 2 miles and an average width of less than one-half mile, the limestones show a less degree of deformation than those of Round Island. The flexures have comparatively gentle dips, amounting in parts of the southeastern portion of the island to only $5^{\circ}$ or $10^{\circ}$. In the western part of the island, however, the dip rises to $90^{\circ}$. The strike, as on Round Island, varies greatly.

A section along the south side of Long Island from the east end to Salt Pond shows the following series of beds:

\section{Section 12, Lon: Is7c.ud.}

Feet.

c. Hard, dark-gray limestone, sligitiy carler than the preceding

270

b. Hard, blue, fine-grained limes:oñ, iracturing easily in any direction_-_-_ 200

a..Buff or cream-colored feldscatiric sandstone underlying the limestones_-- 90

560

The two divisions of tha limestone series are conformable, and the upper and lower portions are very similar in lithologic character. Analyses of the upper and lower portions of the limestone series show them to be very similar in chemical composition, one carrying 96.11 per cent, the other 97.50 per cent of lime.

Aside from the faunal differences, which are quite marked, there are no very evident reasons for making two divisions of the limestones.

Fauna.-The character of the fauna in the lower section $(b)$ of the limestone series is indicated by the following list:

Stictopora sp.

Cladopora sp.

Spirifer cf. sulcatus, Hisinger.

Sanguinolites sp.

Cardiola sp.

Hercynella nobilis, Barr.

Hercynella behemica, Barr.

Holopea sp.

Murchisonia angulata Phillips.

Murchisonia sp. 1.
Murchisonia sp. 2.

Planitrochus cf. amicus.

Loxonema sp.

Holopella sp.

Trochonema sp.

Euomphalopteris? sp.

Operculum.

Beyrichia ? sp.

Leperditia sp.

Orthoceras sp.

The occurrence of the genus Hercynella in this fauna is of considerable interest, since it has not been found heretofore in America. H. bohemica occurs in the lower Devonian of the Ural mountains. Both $H$. bohemica and $H$. nobilis are present in etage $\mathbf{F}$ of Barrand's Bohemian section. Their presence in the fauna at Long Island indicates that the latter is much more closely related to the European and Asiatic than to the American faunas outside of Alaska. This lower fauna at Long Island represents the lowest Devonian horizon which has been found in Alaska.

In the upper portion of the higher limestone $(c)$ the following fauna are found:

F'avosites cf. radiciformis Rom.

Cyathophyllum sp.

Orthophyllum ? sp.

Zaphrentis sp.
Calceola cf. sandalina.

Syringopora sp.

Lingula cf. bohemica.

Atrypa reticularis Linn. 
Atrypa hystrix Hall.

Gypidula opatus (Barr).

Gypidula cf. intervenicus (Barr).

Meristella cf. barrisi Barr.

Stropheodonta stephani (Barr).

Spirifer sp.

Spirifer hians Bich. ?

Spirifer thetidis Barr.

Spirifer Subcomprimatus 'Tsch.

Spirifer sp.

Spirifer indeferens Barr.

Spirifer sp.

Reticularia ? sp.

Rhynchonella cf. amalthea Barr.

Rhynchonella livonica Buch.

Pugnax sp.

Dalmanella occlusa Barr.

Schizophora macfarlani Meek. ?

Schizophora striatula Schloth.

Streptorhynchus sp.

Stropheodonta comitans Barr.

Camarotoechia ? sp.

Cypricardinia ? sp.

Concardium cf. behemicum Barr.

Concardịum sp.
Iucinia cf. proavia Goldf.

Leptodesma sp.

Mytilarca sp.

Nuculites sp.

Telinopsis sp.

Holopella? sp.

Loxonema? sp.

Murchisonia sp. 2.

Murchisonia sp. 1.

Naticopsis sp.

Oriostoma sp.

Oriostoma princeps var. Oehlert.

Euomphalus cf. planorbis D'Arch and Vern.

'Tremanotus cf. fortis Barr.

Tentaculites sp.

Ooceras sp.

Gomphoceras ? sp.

Orthoceras sp.

Cytherella ? sp.

Entomis pelagica Barr.

Lepterditia sp.

Cyphaspis sp.

Proetus sp.

Proetus cf. romanooski Tsch.

In place of the gasteropods which are the dominant forms in the lower horizon the brachiopods are the predominant group of this fauna. The Hercynellas, which are abundant at five horizous in the lower beds, appear to be entirely absent. The upper fauna, however, agrees with the lower in its foreign affiliations. In it occurs the peculiar coral, Calceola, very common in the middle Devonian of Europe. Several specimens among the brachiopods are either identical with or have their nearest analogy in European species. The fauna represents a middle Devonian or late lower Devonian horizon.

The lowest 40 feet of division $c$ of the Long Island section furnished a fauna differing but slightly from that of the upper part. The following list indicates its character :

Cladopora?

Cyathophyllum sp.

Camarotœchia sp.

Meristella cf. Ceres Barr.

Spirifer sp.

Spirifer cf. thetidis Barr.

Spirifer cf. cheiropteryx.

Stropheodonta comitans Barr.

Orthonota sp.
Schizodus sp.

Conocardium cf. behemicum Barr.

Euomphalus planorbis d'Arch and Vern.

Oriostoma princeps var. Oehlert.

'I'entaculites.

Cyrtoceras sp.

Orthoceras sli.

Proetus cf. romanooski Tsch.

The stratigraphic relations of Long Island limestones to the geological horizons represented on the adjacent shore of Kasaan Bay can not be definitely determined because of their topographic isolation.

The middle Devonian horizon again occurs about 20 miles south of Long Island, at the head of Clover Bay, where a small area of schistose argillites and black limestone is found almost completely 40840-Bull. 347-08-4 
surrounded by an intrusive diorite mass. These beds are highly tilted and have a general east-west strike. Fossils gathered from this locality were determined by E. M. Kindle, as follows:

No. 421.- Southwest side of Clover Bay, east coast of Prince of Wales Island. The fossils, which are badly distorted, include the following species:

Favosites cf. hemisphericus. Schizophoria cf. striatula. Stropheodonta perplana. Chonetes cf. mucronatus,
Camarotœchia cf. billingsi.

Pentamerella ? sp.

Atrypa reticularis. Sc:hizodus sp.

The age is Devonian. The faunal evidence, though not conclusive, suggests that the horizon is probably middle Devonian.

This occurrence shows that argillites as well as limestones were deposited during middle Devonian time, but no stratigraphic relations could be determined because they are surrounded by the intrusive mass.

At Vallenar Bay, on the north end of Gravina Island, beds of shaly limestone, argillaceous schist, and schistose conglomerate containing middle Devonian fauna occupy the structural crest of an anticline. These beds underlie the slates and greenstones which border both the east and west shore of the island. Fossils were first found at this locality by Brooks in 1901, and were determined by Charles Schuchert to be Devonian. In 1905 a collection was made at this locality by E. M. Kindle, and in 1906 more material was gathered by the writers. Kindle reports as follows:

One mile west of Vallenar Bay, Gravina Island.-The material from this locality, while generally insufficient for specific determination, is much better than that obtained last year (1905) and leaves no doubt as to the Devonian age of the beds west of Vallenar Bay. Several specimens of Atrypa reticularis: are present. This species fixes the horizon as not later than Carboniferous, while the association of Chonetes cf. manitobensis, Spirifer sp., Proetus sp., and Cyclonema sp. indicate a horizon of Devonian age, probably middle Devonian.

The Devonian beds at this locality and those on Long Island are included under the name "Vallenar series" by Brooks ${ }^{a}$ and are described in his report on the Ketchikan district.

Limestone beds containing an upper Devonian fauna, and overlying with apparent conformity banded argillaceous beds. similar to those of middle Devonian age exposed at Clover Bay, occur in a small cove 6 miles south of Klawak on the west coast of Prince of Wales Island.

Kindle reports as follows on a collection made at the above locality:

No. 854.- Point 6 miles south of Klawak, west coast of Prince of Wales Island.

${ }^{a}$ Brooks, A. H., Ketchikan mining district : Prof. Paper U. S. Geol. Survey No. 1, 1902, p. 42. 
Fauna comprises:

\section{Zaphrentis sp.}

Cyathophyllum cf. geniculum.

Cladopora cf. rœmeri.
Productella hallana.

Spirifer cf. anossofi Verneuil.

The Productella hallana and spirifor cf. anossofi Veru., are represented by a number of specimens and seem to be the most abundant fossils at the locality. S. anossofi is a representative of the Ural Mountain fauna, and is closely related to S. hungerfordi of the Iowa Devonian. Productella hallana is a common species in the western American Devonian and is also found in the Ural Mountains. The horizon represented by this fauna is upper Devonian.

Three miles northwest of the above locality, on a point opposite Fish Egg Island in Klawal Inlet, the same horizon is again represented. The limestone beds strike northerly with steep dip to the northeast, and are underlain as at the above locality by banded siliceous slates. The duplication at these localities is apparently due to folding; though the folds were not clearly defined.

Kindle makes the following report upon the fossils collected at this locality:

Point north of Fish Egg Island, Klawal Inlet, near Prince of Wales Island.A small collection from this locality is composed mainly of corals and small ostracods. It includes Stromatopora sp., Cyathophyllum sp., Striatopora sp., and Cyrtina n. sp. This assemblage indicates a horizon of probably late Devonian age. The Cyrtina, with finely striated fold and sinus, suggests a horizon not earlier than upper Devonian.

South of these two localities of upper Devonian fauna, on the east side of San Juan Bautista Island, the same horizon is again represented. The limestone beds at this point strike northwesterly with a flat dip to the southwest, and a wide belt of granite invades them and occupies the central part of the island (Pl. I).

Kindle submits the following report on the fossils gathered at this point:

Southwest end of San Juan Bautista Island.-The presence of Spirifer disjunctus and Productella cf. lachrymosa in the fauna from this locality indicates a horizon of upper Devonian age. There are also present Cyathophyllum sp., Athyris cf. angelica, Atrypa reticularis, and other species.

The limestones at the latter localities represent the uppermost horizon of the Devonian recognized in this province. To the north, however, on Chichagof Island the upper Devonian is terminated by a considerable thickness of submarine melaphyre lava flows and tuffs interstratified with and overlying upper Devonian limestone beds. Fossils were also present in the tuff beds, thus defining the age of these extrusives. These melaphyre lavas, however, were not observed in the Ketchikan or Wrangell districts.

The distinctions between the three divisions of the Devonian, the upper, middle, and lower, in most places are not clearly defined paleontologically, and at no locality was a complete section of these 
horizons obtained. It was therefore, necessary to group the Devonian under two divisions in the stratigraphic table (p. 35), namely, upper to middle Devonian and middle to lower Devonian.

\section{CARBONIFEROUS.}

The stratigraphic relations between the early Carboniferous and the late Devonian formations are not definitely known, and in 110 place were the formations observed together. On Chichagof Island, north of this province, lower Carboniferous limestones overlie the upper Devonian volcanic bèds with apparent conformity, though this relation was but poorly defined. The same horizon of the lower Carboniferous is represented by fossil-bearing limestones on an islet at the entrance to Soda Springs Bay, on the west coast of Prince of Wales Island. The limestone beds strike northerly and are steeply tilted toward the east; they overlie with apparent unconformity conglomerates and sandstones which resemble those of early Devonian age. On Prince of Wales Island opposite this islet are slates and chlorite schists which resemble those probably belong. ing to the upper Carboniferous.

The collection of fossils from this locality was referred to G. II. Girty, who reports the following:

The Soda Springs Bay collection contains the following forms:

Zaphrentis sp.

Menophyllum? sp.

Derbya sp.

Schizophoria? sp.

Chonetes sp.

Productus aff. punctatus.

Prođuctus aff. mesialis Hall.

Productus aff. setiger Hall.

Productus hirsutiformis Walcott.
Productus aff. cora D'Orbigny.

Productus aff. concentricus Hall.

Productus aft. burlingtonensis Hall.

Spirifer aff. bisulcatus Sowerby.

Spirifer aft. keokuk Hall.

Spiriferina sp.

Reticularia aff. setigera Hall.

Athyris aff. lamellosa L'Eveille.

This lot clearly belongs to the lower Carboniferous fauna.

On the south end of Gravina Island 3 miles north of Dall Head fossils were found in beds of calcareous schist, which because of their ambiguity could not be definitely determined, but are pro. visionally referred to the lower Carboniferous. These, however, may represent a Triassic horizon.

Girty reports as follows on this collection:

Cove 3 miles north of Dall Hcad, west side of Gravina Island.

Zaphrentis sp.

Lithostrotion sp.

Cyrtina sp.

Martinia ? sp.

Dielasma ? aff. bovidens Tschern., non

Martin.

Dielasma ? aff: millepunctatum.

Aviculipecten ? sp.
Halobia ? sp.

Pteria ? sp.

Tetinka ? cf. bellula Barrande.

Loxonema? sp.

Euomphalus ? sp.

Pleurotomaria sp.

Naticopsis sp.

Several undetermined forms.! 
By the presence of Halobia?, which is very similar to if not identical with that which occurs in lot 17 on the Yukon (determined as lower Carboniferous), as well as by certain other particulars, a correlation of the two horizons is suggested, and perhaps for the present that is the best disposition which can be made of this very ambiguous collection. At the same time the two faunas are rather widely different.

Few data exist concerning the interval between the lower and upper Carboniferous faunas, as the two formations are nowhere present at the same locality and no fauna representing the intervening period has been found. The upper Carboniferous, which probably includes the most extensively developed formations, is represented by limestone beds at Saginaw Bay and Keku Islets at the north end of Kuiu Island. The beds there overlie sandstone and conglomerate with a suggestion of unconformity. The determination of the fossils contained in several collections from the limestone beds on Keku Islets and Saginaw Bay indicates a lower and an upper series, both of the upper Carboniferous formation. Girty in his report on these collections states:

These two series, but especially the upper, are what have previously been determined as Permian in the Alaska Range, but $I$ really find that the resemblance with the Gschelian stage of the Russian section is greater than with the Russian Permian. Provisionally, therefore, I will correlate this horizon with the Gschel-stufe, in which occur a great number of equiralent or identical species. This fauna is entirely unlike anything in the Mississippian province of the United States, but some of our western faunas resemble it.

On the northernmost of the Keku Islets about 130 feet of a white, cherty limestone occurs, which is underlain conformably by about 100 feet of shale, sandstone, and conglomerate beds, the latter consisting of cherty pebbles and limestone fragments, which are interstratified with narrow beds of limestone containing numerous fossils. These beds had a N. $10^{\circ}$ to $30^{\circ} \mathrm{W}$. strike and dip of $30^{\circ}$ to $50^{\circ} \mathrm{NE}$. Girty in his report notes the following list of genera from the above locality :

$$
\text { Fossils from northernmost of Keku Islets. }
$$

Fusulina aff. I. longissima Moell.

Stenopora sp.

Rhombopora sp.

Meekella? sp.

Derbya? sp.

Chonetes aff. C. trapezoidalis Waagen.

Productus aff. P. cora D'Orb.

Productus aff. P. humboldti D'Orb.

Productus aff. P. koninckianus Vern.

Productus aff. P. fasciatus Kut.

Productus aff. P. tartaricus - Tsch.

Productus aff. P. lineatus Waagen.

Productus semireticulatus Martin.

Productus aff. P. jakovlevi Tsch.
I'roductus n. sp. aff. P. tuberculatus Moell.

Productus sp.

Marginifera aff. M. juresanensis Tsch.

Spirifer cameratus Tsch., non Martin?

Spirifer arcticus Houghton?

Spiriferina aff. S. pyramidata Tsch.

Squamularia sp.

Pugnax aff. utah Marcou.

Rhynchopora aff. R. geinitziana Tsch. Rhynchopora aff. R. nikitini Tsch.?

Camarophoria aff. C. purdoni Davidson.

Camarophoria aff. C. superstes Vern. 
Streblopteria sp.

Aviculipecten aff. A. mccoyi M. and $\mathrm{H}$.

Aviculipecten, $2 \mathrm{sp}$.

Pinna? sp.

Schizodus sp.

Capulus sp.

Straparollus sp.

Bulimorpha? aff. B. peracuta M. and H.
Pseudomelania sp.

Loxonema aff. L. subgracilis Netch.

Turbonellina aff. T. chatzepovkensis Kak.

Pleurotomaria, 2 sp.

Bellerophon sp.

Medlicottia aff. M. ornignana Vern.

Leperditia sp.

This fauna belongs to the lower series of the Gschelian or upper Carboniferous.

A few miles west of the Keku Islets the Carboniferous limestone is again found on Kuiu Island along the east short of Saginaw Bay. It forms a belt of outcrops from Cornwallis Point nearly to the head of the bay. The peninsula forming the east side of the bay is in an area of moderate folding where deformational forces have exerted a minimum influence, so that the rocks are but slightly metamorphosed and the preservation of the fossils is exceptionally good. At the north end of Halleck Harbor, near the entrance of Saginaw Bay, the axis of a gentle fold, apparently only 600 or 800 yards across, lies near the middle of the cove. The dip of the beds in this fold varies from $8^{\circ}$ to $45^{\circ}$. Another small fold may be seen just west of Halleck Harbor. The trend of these folds is variable, but is generally northwesterly and southeasterly. The section exposed in Halleck Harbor is very similar to that shown on Keku Islets. Beds of white cherty limestone 450 feet or more in thickness overlie a series of black, carbonaceous shales, calcareous sandstones, and conglomerates with an exposed thickness of 125 feet. This section is of special interest because the faunas present in its upper and lower divisions represent respectively the upper and lower series of the upper Carboniferous formations. In the lower beds of the section, which is exceptionally rich in genera, Girty identified the following forms:

\section{Fossils from Halleck Harbor, Kuiu. Island; lower division of upper Carboniferous.}

Fusulina aff. F. longissima Moell.

Crania sp.

Schizophoria? sp.

Derbya aff. D. robusta Hall.

Chonetes sp.

Chonetes aff. C. trapezoidalis Waagen.

Productus aff. P. humboldti D'Orb.

Productus aff. P. porrectus Kut.

Productus aff. P. semireticulatus Martin.

Productus aff. P. schrenki Stuck.

Productus cora D'Orb.
Spirifer aff. S. ufensis Tsch.

Spirifer cameratus Tsch., non Martin?

Squamularia n. sp.

Martiniopsis sp.

Rhynchopora aff. R. geinitziana Tsch.

Dielasma sp.

Streblopteria sp.

Aviculipecten aff. A. mccoyi M. and $\mathrm{H}$.

Aviculipecten, 2 sp.

Entolium aff. E. aviculatum Meek.

Solenopsis? sp. 
In the overlying limestone beds belonging to the upper series Girty reports the following:

Fossils from Halleck Harbor, Kuiu Island; upper division of upper
Carboniforous.

Zaphrentis? sp.

Crinoid fragments.

Stenopora sp.

Streptorhynchus aff. S. pelargonatum Schloth.

Chonetes, 2 sp.

Productus aff. P. timanicus Stuck.

Froductus aff. P. aagardi Toula.

Productus aff. gruenewaldti Stuck.

Productus aff. P. humboldti D'Orb.

Productus aff. P. mammatus Keys.

Productus aff. P. lineatus Waagen.

Productus aff. occidentalis Newberry.

Productus sp.
Spirifer aff. S. alatus Schloth.

Spirifer aff. S. blasi Vern.

Spirifer articus Houghton.

Spirifer n. sp. aff. S. marconi Waager. Spirifer aff. S. dieneri Tsch.

Spiriferina aff. S. cristata Schloth.

Squamularia sp.

Cleipthyris sp.

Camarophoria margaritovi Tsch.

Camarophoria aff. C. purdoni Davidson.

Rhynchopora aff. R. nikitini Tsch.

Rhynchopora aff. R. geinitziana Tsch. Dielasma sp.

Corresponding fauna have been found in the limestone beds at Taku Harbor on the mainland in the Juneau district, and in the Ketchikan district limestone beds rich in coral fragments and probably of the same horizon occur at the head of George Inlet.

These two localities in the mainland belt are included in a successsion of argillites and crystalline schists which are closely folded and highly metamorphosed and form a band from 5 to 15 miles wide striking northwesterly along the southwest flank of the Coast Range intrusives. These metamorphic strata, which are called the "Ketchikan series " ${ }^{a}$ in this province and in the Juneau district the "Schist band," ${ }^{b}$ probably include many different formations which, however, can not be defined because of the complexity of structure and the metamorphism developed in them.

At the Taku Harbor locality, 25 miles south of Juneau, specimens of Productus aff. P. gruenewaldti Krot. were found by E. M. Kindle in 1905 in a much-altered limestone at the base of the slate-greenstone band defined by Spencer. ${ }^{c}$ They determined definitely the age at this point as upper Carboniferous. At the George Inlet locality a large collection of fragmentary corals was gathered at a point on Revillagigedo Island and submitted to E. M. Kindle, who reports.the following:

No..966. Point on southeast side of George Inlet 10 miles from its head, Revillagigedo 1sland.-The fossils from this point comprise only crinoid stems, which, however, are so abundant as to make up a large portion of the rock. Crinoid stems can not ordinarily be used for correlation. However, their great

\footnotetext{
a Brooks, A. H., Ketchikan mining district : Prof. Paper U. S. (Geol. Survey No. 1, 1!)!', p. 42.

${ }^{b}$ Bull. U. S. Geol. Survey No, 287, 1906, pp. 16-17.

$c$ Irlem, pp. 18-19.
} 
abundance here seems to justify a surmise that they very probably represent a Carboniferous horizon. Crinoids in such abundance as is shown by these specimens occur in very few places, if anywhere, outside of Carboniferous horizons. In the absence of other evidence the horizon represented may be referred tentatively to the Carboniferous.

A third fossil locality in this mainland belt was discovered by L. M. Prindle at a point just north of the town of Wrangell. The inclosing rock strata were argillaceous black slates, and the fossils contained were so poorly preserved that definite paleontologic statements could not be made in regard to them. They were referred to G. H. Girty for examination, who submits the following report:

The fossils in question consist of two specimens of pelecypod shells, both apparently belonging to the same species. In their present state the ultimate generic characters are concealed, and, though it is sometimes possible to determine the genus satisfactorily without these characters, as by some peculiarity of shape, such determination is not possible with the present examples. In fact, even specific characters have been more or less obscured and changed, so that these shells might belong almost equally well to several genera whose range and geologic age, so far as paleontologic evidence is concerned, might be almost anywhere from Devonian to Recent. If Paleozoic, I would feel disposed to refer them, by reason of their shape and sculpture, to the genus $E d$ mondia, though such a reference would be little more than a surmise. The range of Edmondia is practically restricted to the Devonian and Carboniferous. It is with sincere regret that $I$ submit a report as unsatisfactory as I know this must be, but I feel that the evidence would not justify a stronger or more definite opinion.

In view of the comparatively weak paleontologic and stratigraphic evidence bearing on the precise age of these argillites and crystalline schists, it is possible that their period of deposition extended even beyond the Carboniferous period into the Triassic, especially when the extensive development of Triassic strata to the south in British Columbia, as described by G. M. Dawson, ${ }^{a}$ is taken into consideration. The evidence thus far gathered, however, indicates Carboniferous age for the greater portion of these crystalline schists and argillites. Besides their distribution along the mainland and adjacent islands, they are developed widely on Prince of Wales. Island and to a limited extent on Kupreanof Island.

The most recent Paleozoic rocks in this province are upper Carboniferous lava and tuff beds interstratified with beds of black slate. (Pl. VII, A.) This age determination is based on their structural relations to the older and younger rocks and on the fact that the upper Carboniferous strata at Taku Harbor underlie the greenstones with apparent conformity. These beds in the Juneau district are described at length by Spencer as the "slate-greenstone band." These strata trend in many places parallel to the older limestones and schists and have been subjected to the same dynamic forces that

${ }^{a}$ Geol. Nat. Hist. Survey Canada, 1879-80, pp. 1-177 B. 


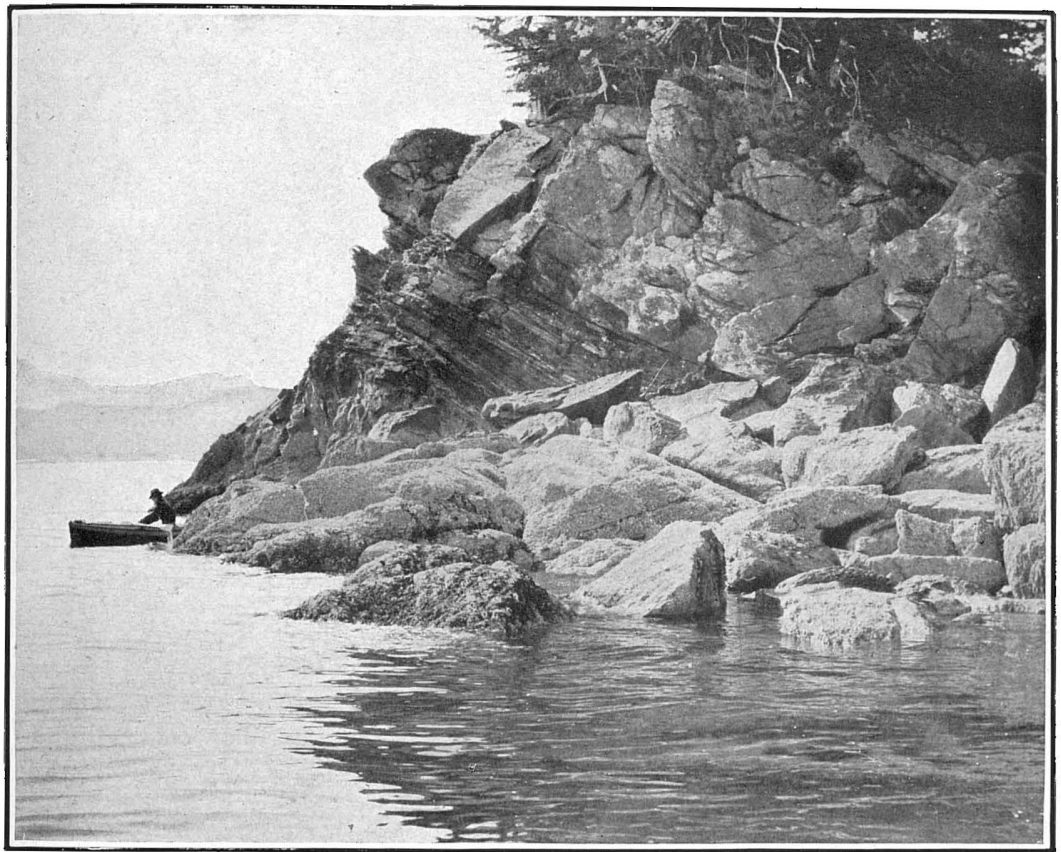

A. INTERStRatification OF SLATE BEDS AND GREENSTONES, NORTH END OF CLEVELAND PENINSULA.

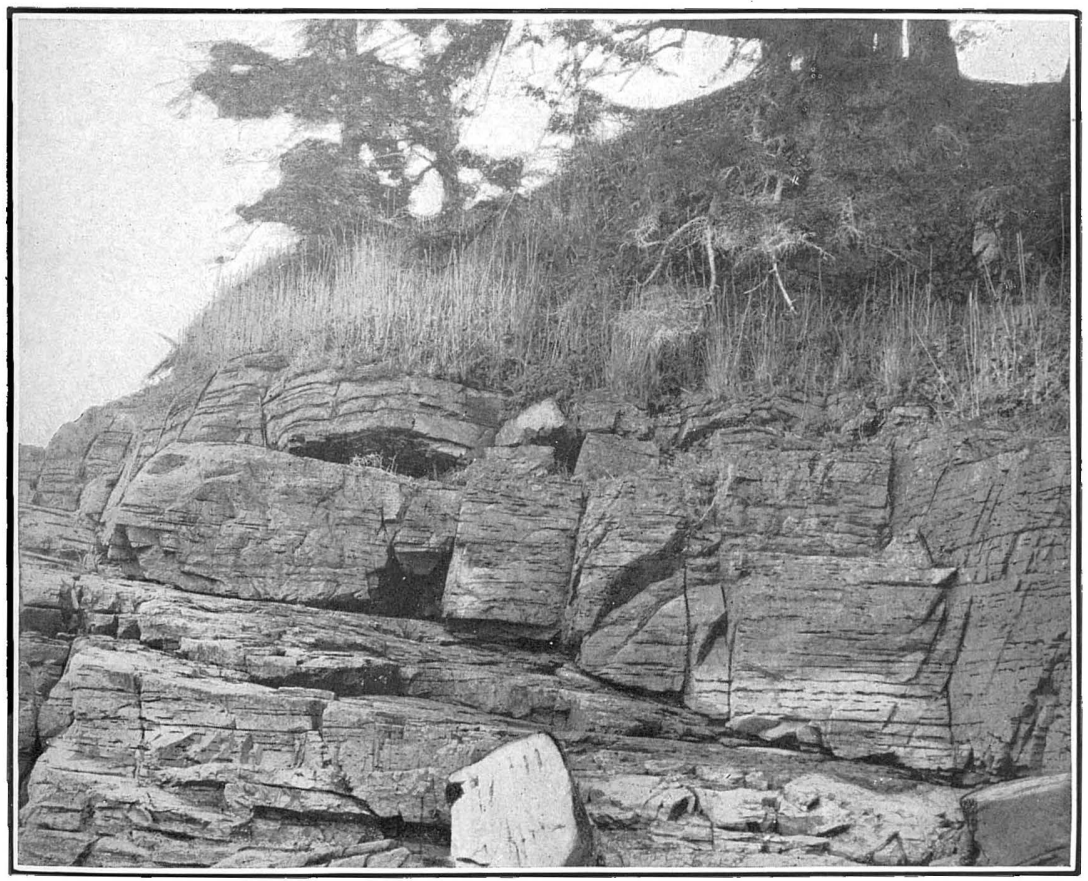

B. FLAT-LYING GRAYWACKE BEDS, NORTH END OF SAN FERNANDO ISLAND. 

produced the northwest-southeast system of folds. The beds are in many places steeply tilted either to the southwest or to the northeast, although local variations in strike and dip are common. The total thickness of these strata has been estimated to be over 4,000 feet. They occur principally along the outer border of the mainland belt, but they also form a smaller belt along the seaward shores of Chichagof and Baranof islands and on the west coast of Prince of Wales Island.

As a whole the greenstone members of this slate-greenstone formation predominate over the slate or the sedimentary beds, but the relative proportion varies from place to place. The variation is attributed to the inequality in distribution of the lava flows and tuffs. In the beds themselves the igneous and sedimentary material is intimately associated in varying amounts and grades from altered andesitic lavas and tuffs to purely sedimentary beds (Pl. VII, $A$ ).

In the Ketchikan and Wrangell districts the slates and greenstones can be traced from Dixon Entrance to Cape Fanshaw, including Duncan Canal, Cleveland Peninsula, and Gravina Island. They as well as the crystalline schists to the northeast are important mineralbearing formations.

Limestone and conglomerate beds of a Carboniferous horizon still higher than that at Saginaw Bay or Taku Harbor occur at Pybus Bay on Admiralty Island and have been recently reported from Hamilton Bay on Kupreanof Island. ${ }^{a}$ The relation of these beds to the slates and greenstones above mentioned is not known, but in the stratigraphic column on pages 34,35 they have been provisionally placed above the slates.

\section{MESOZOIC STRATA.}

The formations in the Ketchikan and Wrangell districts that have been referred to the Mesozoic era have no fossils, and their classification is therefore based entirely on structural and petrographic evidence. The only Mesozoic fossil found was in a loose fragment of limestone picked up at the head of Hamilton Bay. 'It was identified by T. W. Stanton as Pseudomonotis subcircularis (Gabb), which is characteristic of a horizon near the top of the upper Triassic. No similar rock was seen in place and the source of the specimen is unknown, but it probably represents Triassic beds in southeastern Alaska and thus shows that deep-sea conditions existed along the coast at that period.

So far as known, the Coast Range intrusives, which occupy about half the land area of southeastern Alaska, invaded the bedded forma-

a Mr. W. W. Atwood visited this locality in May, 1907, and reported the Hamilton Bay occurrence. 
tions during the early part of the Mesozoic era. These intrusives are discussed under the heading "Igneous rocks."

Un the southern end of Prince of Wales Island is a succession of andesitic flows, conglomerates, and tuffs, which grade into a series of graywackes or indurated sandstones. These have been considered Mesozoic because of their structural and petrographic relations to the older rocks. In this complex, basaltic and andesitic flows are intercalated with the tuffaceous beds, and both flows and tuffs alternate with the sedimentary slates, graywackes, and conglomerates. They are readily distinguished from the greenstones by the wide difference in composition and texture of the interstratified beds and by their predominant reddish color. A fine, compact, green tuff is usually overlain by an andesitic lava with numerous large phenocrysts, which in turn is overlain by a basaltic lava or a red lava conglomerate. The greenstone beds, on the other hand, vary little in composition and where massive, augite crystals form the phenocrysts.

On the south end of Prince of Wales Island the andesitic flows and conglomerates overlie at several points the eroded surfaces of granitic intrusive masses, and numerous dikes of the andesite intrude these older granites. Pebbles and fragmentary masses of the granite were observed in the tuffaceous conglomerates, showing clearly that the andesites are younger than these masses of granitic rock. The granites at this point were more altered and contained more shearing planes than are usual in the Coast Range intrusives, and they may represent a batholith intruded before or during the earliest stages of the period of the Coast Range granitic invasion. The graywackes overlying the andesites are compact and indurated, but do not show a schistose development (see Pl. VII, $B$ ); the numerous slate fragments prominent in the rocks of the Sitka series to the north are absent, and beds of slate are less common. Pebbles of granodiorite, quartz, andesite, and graywacke are plentiful in the conglomerates. These beds, as a whole, though tilted at steep angles and folded, have not suffered the intricate folding and metamorphism shown in the older rock beds including the Sitka series. No fossil evidence was found in these beds, but from the above facts it is reasonable to suppose that they occupy a position in the stratigraphic column between Triassic and upper Cretaceous.

To the north, on Admiralty Island, ${ }^{,}$in Pybus Bay, slaty limestone and conglomerate beds, containing the fossil forms Aucella crassicollis and Aucella piochii, overlie the upper Carboniferous beds unconformably. These lower Cretaceous strata may represent the same horizon as the graywacke conglomerate beds mentioned above, though in the latter no fossils were found. 
TERTIARY STRATA.

The Tertiary beds, as shown in previous reports, ${ }^{a}$ are widely distributed along the North Pacific coast, though their total thickness is comparatively small. In the Wrangell district they are locally developed at Hamilton Bay on Kupreanof Island. On Prince of Wales Island they occupy but a small local area at Coal Bay, a southern arm of Kasaan Bay.

The Tertiary beds comprise an assemblage of conglomerates, sandstones, and lignitic coal seams, together with volcanic lava flows overlying and interstratified with the sediments.

The occurrence of the beds at low elevations, surrounded in places by mountains of Paleozoic rocks, indicates that the Tertiary sediments were deposited in lakes or shallow embayments alternating with swampy land, on which the vegetation of the coal beds accumulated. Erosion and movement of the older rock beds probably caused the local basin-like depressions. The beds are still soft, friable, and unmetamorphosed, though they are in many places fractured and tilted to some extent. However, the deformation of the original horizonal structure is slight when compared with that of the underlying strata. The conglomerates of the Tertiary consist essentially of slate fragments with pebbles of granite, greenstone, and limestone, many of them measuring several inches in diameter. These alternate with beds of sandstone and shale and with them have a general southerly dip of from $5^{\circ}$ to $10^{\circ}$ and an easterly strike. Sandstone is the predominant rock of the Tertiary. It contains less quartz than usual and a large amount of rock fragments, such as slate and limestone, rather than of mineral fragments. The beds are gray to brownish and loosely consolidated, many of them showing cross-bedding. The shale beds contain a high percentage of clay and bituminous matter, and in them are numerous fossil plant leaves.

Coal occurs in beds 3 inches to 3 feet thick, interstratified with seams of carbonaceous shale and sandstone. It varies from a black lignite to a bituminous coal, but nowhere in southeastern Alaska has it been found in commercial quantities.

The gray shales of this sandstone series contain an abundant flora, which F. H. Knowlton considers as probably of Kenai age (upper Eocene). A collection from Hamilton Bay was submitted to him and the following species were identified:

${ }^{a}$ Dall, W..H., Coal and lignite of Alaska: Seventeenth Ann. Rept. U. S. Geol. Survey, pt. 1, 1896 ; Brooks, A. H., Coal resources of Alaska: Twenty-second Ann. Rept. U. S. Geol. Survey, pt. 3, 1902. 
Fossil plants from Hamilton Bay, Alaska.

Sequoia langsdorfii (Brgt.) Heer. Sequoia nordenskioldi? Heer.

Taxodium distichum miocenum Heer. Juglans nigella Heer. Ulmus sp.
Quercus sp. nov.

Laurus sp.

Populus sp.

Alnus sp.

Castalia? sp. nov.

A succession of basaltic lava flows, in which columnar jointing is a well-developed and characteristic feature, overlies the coal-bearing strata, and occupies extensive areas on the northeast end of Kuiu Island and the entire southern shore of Kupreanof Island. These lava beds, with oceasional strata of conglomerate, sandstone, and tuff, have a total thickness estimated at 2,000 feet. In the lower portions of the series exposed along the shores of Port Camden on Kuiu Island narrow seams of impure coal were observed, and fossil plant leaves were collected from the interstratified sandstone beds. Beds of coarse conglomerate with pebbles mostly of volcamie material also occur, grading into the sandstone beds. Strueturald these beds are inclined only a few degrees from the horizontal and have suffered little or no deformation since their deposition.

A collection of plant remains from fine-grained gray argillaceous sandstone, interstratified with the lava conglomerates, was made at a point east of Port Camden, 3 miles south of the entrance. Knowlton states in his report on this flora that the material was ample and very finely preserved and determines the age as Kenai. The plants identified are:

\section{Fossil plants from Port Camden, Alaska.}

Sequoia langsdorfii (Brgt.) Heer. Taxodium distichum miocenum Heer. Taxodium olriki Heer.
Lastræa stiriaca (Unger) Heer. Corylus macquarrii (Forbes) Heer. Juglans nigella Heer.

The above determinations and the stratigraphy indicate that the beds at Hamilton Bay and at Port Camden represent about the same horizon.

The Tertiary beds observed at Coal Bay on the east side of Prince of Wales Island are very limited in extent and apparently occupy a local basin formed in the underlying Paleozoic rocks.

An exposure of these beds one-third of a mile up the creek at the head of Coal Bay showed the following section:

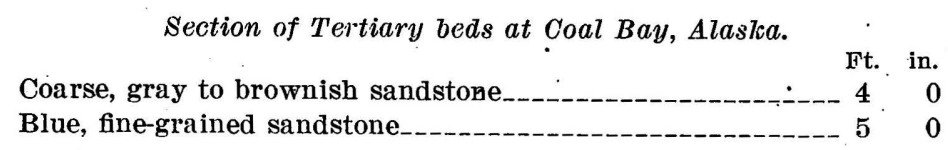

The strike of these beds was N. $60^{\circ} . \mathrm{W}$., and the dip $15^{\circ} \mathrm{NE}$. The coal is a brownish-black lignite of light weight and contains occa- 
sional grains of amber. It is said to burn poorly, leaving much ash. Two shafts, one 20 and one 40 feet deep, have been sunk at this locality without satisfactory result:

Pliocene beds like those which occur along this coastal belt farther northwest, at Lituya Bay, and gravel beds containing marine shells, which are present at points in the Juneau district, have not been observed in the Ketchikan or Wrangell districts.

The most recent rocks are the basaltic lava flows along the mainland and on Revillagigedo Island, in the Ketchikan district. These are described in the following pages under "Igneous rocks."

\section{IGNEOUS ROCKS.}

The igneous rocks include (1) the intrusive masses, as the granitic batholiths, gabbros, and peridotites which invade the sedimentary rock beds, (2) the extrusives, or those which represent surface lava flows during the different geologic periods, as the greenstones, andesites, and basalts. The most abundant and important of the igneous rocks are the Coast Range granitic intrusives, which occupy about one-half of the aggregate land area of these two districts.

\section{COAST RANGE INTRUSIVES.}

GENERAL DESCRIPTION.

The Coast Range massif, as it has been defined by Dawson, is not of the same composition throughout but is composed of different kinds of igneous rocks ranging from granite to diorite and even gabbro; quartz-hornblende diorite or tonalite being the predomi nating type. The most noteworthy feature of the entire Coast Range mass of intrusives is their general uniformity in texture and their continuity. The variations across the range are apparently not so gradual as those along its trend. The Coast Range massif consists of many separate interlocking batholiths, or batholiths within batholiths, intruded at successive epochs but during the same general period of irruption. In the southern part of Alaska, especially in the Unuk River, Stikine River, and Portland Canal sections, the contacts between the different batholiths are less sharp than in the northern Skagway cross section. The geologic evidence indicates that the granite in the southern region was intruded into more deeply buried rocks than that in the northern region, and this fact may acount in part for the difference in contacts. It is probable that under such very deep-seated conditions, owing to the general similarity in composition between the masses, local gradations would take place at the contacts and obliterate the sharp lines of demarcation which would result if the superheated intrusive masses were nearer the surface and in contact with cooler surrounding rock masses. 
In this portion of the Alaskan Coast Range rapid gradations from one type to another occur and indicate in many ways intrusion within jntrusion besides variation due to differentiation and assimilation. Naturally it is not probable that intrusion was or could be accomplished over such a wide area at one time and by one huge magma. For the gradual relief of strains and stresses due to the transfer of so much material and also for the action of a viscous magma the lapse of considerable time must be assumed. Furthermore, all conceptions of the mechanics of mountain building involve the consideration of a complicated system of forces, which require nice adjustment to be brought into equilibrium; local differential forces of compression or tension must be relieved by changes in relative position, while the larger orogenic tangential or radial forces must also find eventual expression and relief in mass transfer, as by batholithic intrusions and orogenic uplift. We have, then, to deal with a dynamic system tending toward static equilibrium, and therefore the time element is involved in our general conceptions of the mechanics of the problem.

Several interesting facts were observed in the field which have a bearing on the general problem of the explanation of the Coast Range intrusion. Jointing planes and sheeted zones are often well marked in the granodiorite, and trend northwest with steep northeasterly dips. In the southern part of southeastern Alaska, particularly along the shores of Behm Canal, pegmatite and aplite dikes form an intricate network and mesh of white strands along the outer portions of the granodiorite massifs and in the adjacent schists, but in the central parts of the batholiths they are practically absent. Several systems of such dikes were observed; the oldest set occurs as thin, narrow bands following master joint planes and standing out as ribs above the surface of the more easily weathered granite; a second set is wider and usually perpendicular to the first; while a third and still later set, which is distinctly irregular, apparently fills the largest fracture cracks. This condition suggests that during the last period of magmatic activity the rock masses underwent considerable movement and fracturing and were brought nearer the surface. That still later differential movement has taken place is evident from the minor faulting of the pegmatite dikes themselves. At a distance this schist complex with its innumerable pegmatitic dikes, resembles a breccia, the white pegmatites acting as interstitial cement for the dark angular fragments and blocks of schist.

The sedimentary rocks flanking the Coast Range batholiths in this region are folded closely near the contact and more openly at a distance, so that, though their general trend is parallel to the range, their dip is extremely variable, ranging from northeasterly to southwesterly at all angles. Such dips, however, do not exist throughouit southeastern Alaska, for northward from Behm. Canal, 
in the Wrangell and Juneau districts, the strike and dip become more and more constant, the schists are more typically developed, mineralization along certain bands is more pronounced and sharp, and closed and overturned folds appear to be the rule. The prevailing dip is steeply northeast into the mountains, and the strike is parallel to the range. The economic bearing which this change in structure has had on the formation of ore bodies is interesting and is discussed on page 77.

Petrographically the field term granite, which is generally used to designate the Coast Range intrusives, applies to only a small part of the rocks. The prevalent type is less siliceous and ranges in composition from granodiorite to diorite and gabbro, with hornblende and biotite as colored constituents and titanite as a frequent visible accessory component. As a general rule hornblende appears more abundant near the coast, while biotite predominates near the inland border of the Coast Range batholiths. Near the coast also the granite is usually more gneissoid in aspect, especially along Behm Canal, and contains abundant inclusions of the intruded schist near its contact. These inclusions become more and more coarsely crystalline away from the contact, until finally they resemble basic or acidic differentiation products and are gradually lost sight of. A characteristic feature in this region is that while aplitic and particularly pegmatitic dikes are extremely abundant near the western contact of the granite and form an intricate network in the adjoining schist areas, they are rare and practically absent in the central parts of the range. On its eastern flanks numerous salic dikes occur, but they are far less abundant than on the coastal side. The absence of minette and similar basic differentiation dike products is noteworthy and may be due to the fact that the dikes are pegmatitic rather than aplitic and, therefore, are not, strictly speaking, magmatic differentiation products in the usual definition of the word.

The importance of the pegmatites becomes apparent when the mode of formation from a solution emanating from the intrusive mass is considered. They represent only a small part of the work accomplished by the pneumatolytic solutions of the granite and are convincing evidence of the great volume of pneumatolytic solutions which accompanied the batholithic invasions. The intimate connection of the ore bodies in southeastern Alaska with the intrusive masses has been proved directly in several places and is inferred in a number of the remaining deposits.

AVERAGE COMPOSITION OF THE COAST RANGE BATHOLITHS.

Although the composition of the Coast Range granodiorites varies considerably from point to point, it is desirable to ascertain the approximate average composition of the entire mass. To this end 
seven typical specimens were selected from different parts of the range. 'These specimens were chosen with special regard to their abundance and general distribution throughout the area, abnormal and rare types being disregarded altogether. Each of these specimens was studied in detail under the microscope, and a careful estimate of the relative quantity of each mineral in the rock was made from the thin sections by the Rosiwal method. Although the values thus obtained are necessarily only first approximations, they represent roughly the general mineral content of the Coast Range granodiorite.

The following average mineral composition was thus obtained:

Average mineral composition of the Coast Range intrusive.

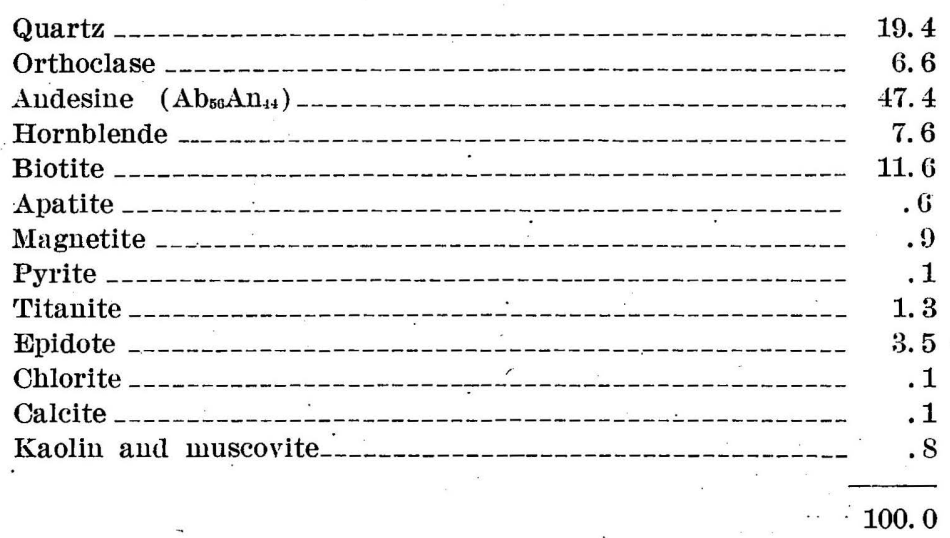

The average specific gravity, 2.77 , was determined by weighing the hand specimens in air and then in water.

From these data the average chemical composition was calculated by assuming for the hornblende and biotite the compositions of like minerals from a similar rock from Butte, Mont.

Average chemical composition, norm, and classification of the Coast Range intrusive

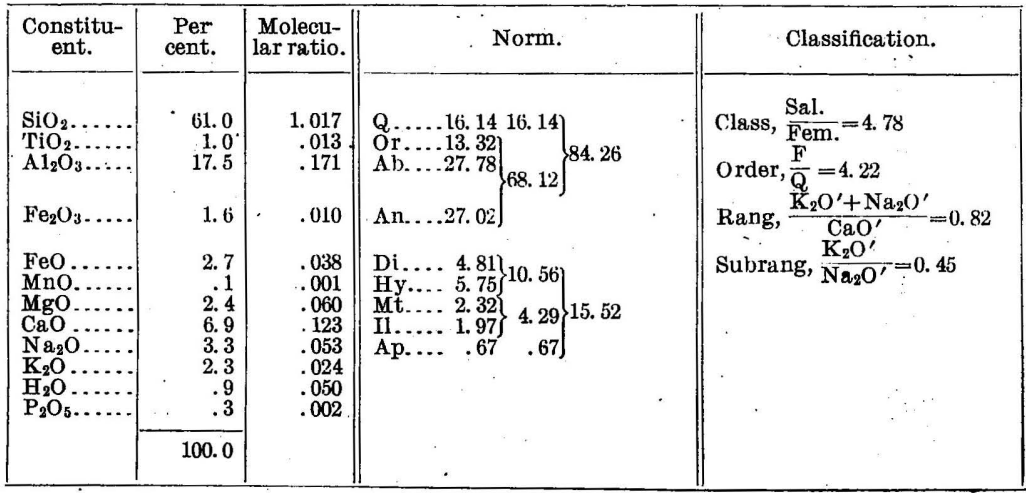


This chemical and mineral composition places the rock in the family of the quartz diorites, of the type tonalite according to the usual classification. In the new quantitative classification of Cross, Iddings, Pirsson, and Washington the rock is dosalic, dosalone quardofelic, alkalicalcic, and dosodic, and belongs in Class II, order 4 (austrare), rang 3 (tonalase), and subrang 4 (tonalose). In short, it is tonalose of the ordinary type.

The amount of titanite is unusual and is characteristic of many of the Coast Range intrusives. The highly lustrous, well-shaped crystals of this mineral glisten in the sunlight and attract the attention of the most casual observer. The hornblende occurs usually in dark prismatic crystals, noticeable for the excellent prismatic cleavage and the lack of terminal faces. Many biotite flakes are hexagonal and deep brown in transmitted light. A few apatite crystals are visible to the unaided eye, but this mineral occurs generally in fine hexagonal crystals of microscopic dimensions. Pale green veinlets of secondary epidote, which follow fracture planes in the granodiorite, are not rare.

These even-grained rocks usually have the normal, sharply defined, granitoid texture. However, gradations to holocrystalline porphyritic phases, due to the superior development of the feldspars, occur. Gneissic structure is common near the western margin of the Coast Range belt. In some places the development of gneissic structure in the granite has been so far advanced and the recrystallization of the neighboring invaded sediments to gneiss has been so thorough, that it is difficult to define the precise limits of the original intrusive granite.

CONTACT METAMORPHISM.

That the immense Coast Range batholiths are not surrounded by evident contact aureoles of similar proportions has been frequently noted. Contact minerals have been observed only rarely and are of local significance.

In metamorphic alteration those changes in mineral combinations take place which tend to produce under the given conditions more stable equilibrium throughout the system. It is probable that at many points along the western flanks of the batholiths the schists now visible were so deeply buried at the time of intrusion that the invading granite did not alter them so materially as to produce wide contact change. Strata nearer the surface at the time of intrusion should show more pronounced alteration from the magmatic solutions and the heat. Although the strata directly above the massifs have long since been removed by erosion, an observer approaching the contacts from the southwest finds that distinct changes in the sedimentary rocks are generally noticeable, especially in the southern 40840-Bul1. 347-08 -5 
portion of southeastern Alaska. The prevailing argillites become more visibly crystalline, and at many points, especially in the Wrangell district, new minerals, andalusite and staurolite, occur. From the coast of Behm Canal to the western contact of the Coast Range massif the invaded sedimentary rocks change from slates and argillites to phyllites and mica schists and in some places near the contact to gneiss. The many types of hornfels are rare, and spotted schists do not form an integral part of the complex. The strata are intensely folded and.were undoubtedly deeply buried at the time of the granite invasion. Deep-seated metamorphic forces were already active and had undoubtedly heated and altered the rocks to such an extent that the granitic intrusion did not disturb their equilibrium. greatly; its chief effect being to accentuate the processes of crystallization already in force and to increase their power rather than to replace them by others. At the contact itself, the granite frequently contains inclusions of the schist, which have usually become more coarsely crystalline, though their original outline is still well preserved. This coastal strip exposed along Behm Canal, whose contact with the granite can be traced only with difficulty, offers, therefore, an excellent example of the metamorphic changes produced by deeply buried granite.

It is significant that in these deep-seated schists and gneisses near the granite contact no ore bodies of consequence have been found, while rocks farther away from the granite and nearer the surface during its invasion in many localities show traces of contact metamorphism, as in spotted schists, and contain valuable metalliferous deposits. The folded character and lack of uniform structure in the strata near the granite contact may account in part for the absence of commercial ore deposits, since they offer no lines along which concentration could easily take place as in the isoclinal schists of the Juneau district farther north. Within the granite area itself are occasional belts of included sedimentary rocks in a highly metamorphosed condition. They vary from argillites to mica, hornblende, and calcareous schists of various types, even marble, and occur in long bands, intensely folded. They still preserve in general their northwest trend, parallel to the course of the range, and their steep northeasterly dip and are walled in by great mountain masses of intrusive granite. In the region about Glacier Bay the granite contains numerous inclusions of schists arranged irregularly and showing beyond question that cleavage had been superinduced upon them before the granite intrusion. From general structural relations in the Juneau district Spencer ${ }^{a}$ has concluded that the schistosity and steep isoclinal dip to the northeast characterized the

${ }^{a}$ Spencer, A. C., Bull. U. S. Geol. Survey No. 287 , 1906, pp. 13-15. 
schists before the entrance of the batholiths and controlled at the time of invasion the form of intrusion by offering parallel lines of least resistance along the planes of schistosity. So far as the writers' experience in the Juneau district goes, this conclusion is justified by the facts and is further strengthened by the exposures in Glacier Bay.

The included schist belts within the Coast Range are usually not wide, and more appear near the mountain tops than at sea level. They can be traced up the exposed cliffs and bare mountain sides for 4,000 to 6,000 feet. They are usually intensely mineralized with sulphides, especially pyrite, and near the mountain crests show abundant evidence of contact metamorphism, formation of garnetiferous rocks, etc. These roof pendants, as R. A. Daly ${ }^{a}$ has aptly named them, were directly above the intrusive mass and were evidently in the most favorable position to be affected by magmatic waters and heat escaping from the intrusives, so that they now are the most heavily miner- alized bodies.

The character of the invaded sedimentaries east of the inland border of the granite is noticeably different. The slates and sandstones are less altered and typical schists and sandstones are rare. Folding and particularly faulting are common and characteristic of the entire complex (Pl. VIII, A). The granite contact line is sharp and frequently traverses the bedding planes of the intruded strata. Although its general trend is parallel to the Coast Range, the actual line of contact exposed in the Unuk River section undulates locally and crosscuts the strata at variable angles. The intruded rocks are often indurated and heavily mineralized with sulphides near the contact and show evidence of metamorphism by the intrusives.

By comparing the metamorphic effects of the intrusive granite along its western and eastern flanks in the latitude of the Ketchikan district decided differences are apparent. On the coastal side the metamorphism near the contact is usually of the deep-seated type; gneisses and schists predominate and are cut by innumerable pegmatite dikes ramifying from the granite. Mineralization by sulphides is not pronounced near the contact. Farther west, at some distance from the contact, evidences of contact metamorphism increase, the degree of mineralization also increases, and valuable ore bodies have been discovered within this zone in the Ketchikan district. Along the eastern border of the granite, on the other hand, the metamorphism is of the contact type, argillites and slates predominate and are often indurated and heavily impregnated with sulphides. Welldefined ore bodies have been found near the granite contact. The geologic interpretation of these data indicates clearly that the rocks

${ }^{a}$ Am. Jour. Sci., 4th ser., vol. 15,1903 , pp. 269-298; vol. 16, 1903, pp. 107-126. 
east of the massifs were less deeply buried at the time of intrusion than those on the coastal side. In other words, the inland rocks were then above the zone of deep-seated metamorphism or rock flowage, and were, therefore, profoundly affected by the invading intrusives and accompanying pneumatolytic solutions. Furthermore, the mineral-bearing solutions emanating from the granite encountered new conditions of temperature and pressure on entering the adjacent sedimentary rocks and deposited, as supersaturated solutions in their new environment, a portion of their dissolved contents, especially the metallic sulphides and silicates.

Although in such a large belt the phenomena of contact metamorphism are not so pronounced and concentrated as in the contact aureole of a small intrusive boss, they are equally as varied, though more extensive and on a larger scale. It has frequently been observerl that in a small contact aureole different contact minerals occur at different distances from the intrusive mass, and that under similar conditions an evident relation exists between a given contact min- eral and its distance from the invading rocks; and in a general way this law apparently holds true for this eastern contact zone of mineralized sedimentary rocks.

DIKE ROCKS AND MINERALIZATION.

The various dike rocks which accompany and intrude the Coast Range batholiths may be arranged in two groups, the first containing the pegmatites, aplites, alaskites, granite porphyries, and allied rocks, and the second containing the lamprophyres of several types, diabases, and other basic intrusives. Although interesting from a petrographic standpoint, these rocks have little commercial value and, with the exception of the pegmatites and aplites, are not of great importance (Pl. VIII, $B$ ).

The pegmatites are not of the usual type, their feldspars being almost invariably oligoclase and not orthoclase or microcline. They are usually pure white and coarse grained and do not contain accessory constituents in abundance. In the central parts of the Coast Range the pegmatites and, in fact, all dike rocks are rare, but along the western margin and adjacent sedimentary rocks hardly a cubic meter of country rock is visible which is not pervaded by them. As noted previously, the pegmatites are not all of the same age, but have been formed at different periods, the older dikes following definite jointings and fracture planes in the country rocks. The occurrence of these innumerable pegmatites along the margin of the Coast Range batholiths is a significant indication of the immense quantities of pneumatolytic solutions given off by the invading crystallizing magmas. In the region of most intense development of 


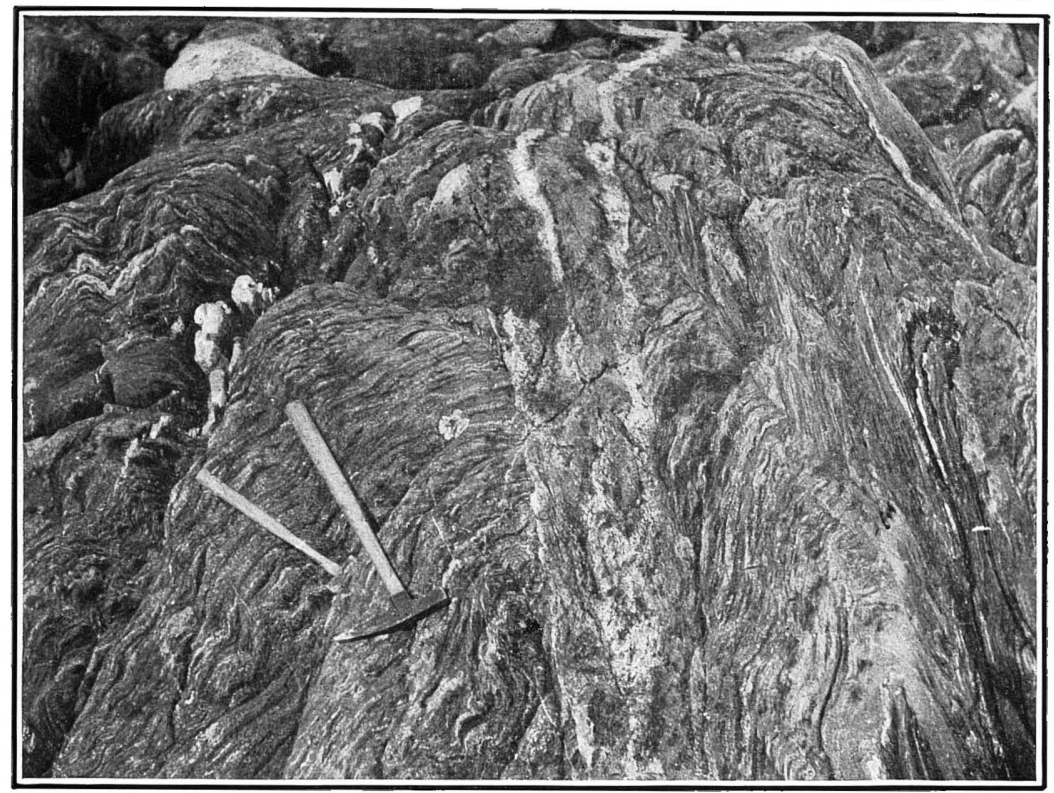

A. CLOSELY FOLDED AND HIGHLY CRYSTALLINE SCHISTS ADJACENT TO THE COAST RANGE INTRUSIVES, BRADFIELD CANAL.

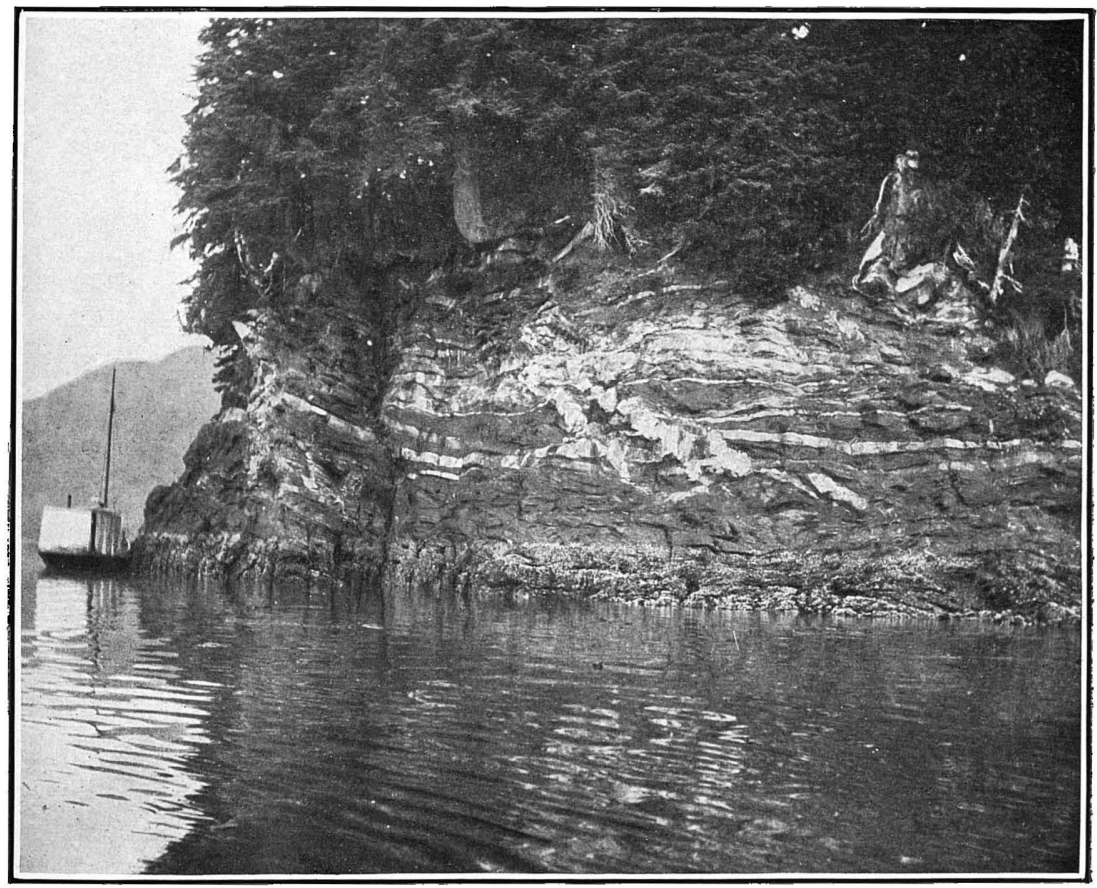

B. APLITE AND PEGMATITE DIKES CUTTING THE C.RYSTALLINE SCHISTS, BRADFIELD CANAL. 

pegmatites, as in the Behm Canal area, the amount of ore deposition was slight and no ore bodies of importance have been discovered.

Farther away from the granitic intrusion magmatic solutions given off by these igneous masses encountered conditions more favorable to the precipitation of the metallic sulphides carried in solution and deposited them at such points. As a result the argillites and slates. a few miles west of Behm Canal, as on Cleveland Peninsula and Revillagigedo Island, are very heavily impregnated with sulphides, especially cubes of pyrite. The total amount of sulphides in these rocks is enormous and would be difficult to explain otherwise than as due to the influence of the Coast Range intrusives. An unfavorable result of this widespread mineralization has been to disseminate the values over large areas and to render the whole of little commercial importance. In certain instances, however, sufficiently intense concentration has taken place within small areas and produced commercial values.

As further evidence of the important part played by the Coast Range intrusives, it may be cited that the ore deposits are apparently all later than these intrusives; that occasionally the pegmatite dikes in this area pass gradually into quartz veins, and that the evidences of contact metamorphism and the development of contact minerals such as staurolite and andalusite are not rare in the heavily mineralized rock belts. Nearer the Coast Range the rocks now exposed were at the time of intrusion deeply buried and therefore extremely hot and under considerable pressure. The solutions, escaping from the granite and entering this complex, encountered conditions not greatly unlike those within the crystallizing granite itself, and sulphide deposition was slight. On reaching the zone of less pressure and colder rock formations, however, the ascending solutions met with new conditions, favorable to the precipitation of sulphides and minerals closely allied to those of ordinary contact metamorphism, where heat and magmatic solutions are the prime agents of metamorphism.

\section{OTHER INTRUSIVES.}

Dikes of diabase, porphyrite, and felsite are common throughout the region and cut all of the older rock strata. Some of these have been indicated on the geologic map. The importance of these rocks, however, is relatively small when compared with the Coast Range intrusives and their accompanying dike rocks which have already been discussed. For the most part these dikes may be considered as the intrusive forms of the greenstones, andesites, and basaltic lavas, described in the following pages. Diabase; which is the most widely distributed dike rock in the region, occurs cutting the ore bodies in many places. It usually has a fine-grained ophitic texture, is dark 
green, and consists essentially of altered plagioclase feldspar, together with basaltic hornblende largely altered to uralite. Both magnetite and pyrite are generally present in disseminated grains. The porphyrites, which may be regarded as the dike rocks of the andesitic lavas, are characterized by their porphyritic texture, by their light-green color, and by large plagioclase feldspar phenocrysts contained in a finely crystalline groundmass.' These dikes, though less common than those of diabase, are also of more recent intrusion than the ore deposits. These dikes are numerous along the shore exposures where they cut the Paleozoic strata and the granitic intrusives.

Dikes of felsite have been noted in only a few places, principally on Kasaan Peninsula, where they are associated with the copper deposits. They are usually brownish and finely crystalline, and are composed essentially of feldspar, many crystals of which form large phenocrysts. They were evidently of later intrusion than the ore deposits, though ore was contained in them in places. Narrow dikes of basalt were observed on Kasaan Peninsula and at other localities. They are usually black, finely crystalline, and porphyritic, and vary widely in composition. The basalts are the most recent intrusive rocks.

\section{EXTRUSIVES.}

GREENSTONES.

The upper Carboniferous extrusives mentioned in the foregoing pages are represented essentially by tuffaceous strata and lava flows, which have been generally metamorphosed and rendered schistose, their original mineral constituents having been replaced to large extent by secondary products. Because of this alteration the former character of the rock has in most places been obliterated, but elsewhere their texture and mineral content mark them as igneous rocks. The interstratification and the intermingling of the igneous material with the black slates indicate that most of the igneous material, composed of tuffs and some agglomerates, resulted from volcanic outbursts. Lava flows also occur, but are less frequent.

The term greenstone, which is a convenient field name, has been applied to the rocks of this type, both schistose and massive, and includes the intrusive as well as the extrusive forms. They are all intensely metamorphosed, have a greenish cast, and range in composition from altered andesites and andesitic tuffs to basalts and altered gabbros.

On Cleveland Peninsula and in the neighborhood of Ketchikan, the greenstones are roughly bedded and conform to the general structure of the neighboring formations. A close study reveals layers varying in composition and coarseness of crystallization, and a few 
beds of amygdaloidal structure, showing the original vesicular nature of the rock. Angular breccias also occur containing fragments of greenstone material. All these features are such as would be caused by a succession of volcanic flows and outbursts, and their igneous origin is thus well established.

In the massive flows are numerous phenocrysts of pyroxene, usually less altered than the groundmass, which is always so decomposed that in many places the original nature of the rock can not be definitely determined. Wherever it is less altered and the original texture is still apparent, considerable amounts of plagioclase feldspar and augite phenocrysts are present and the lavas have the typical features of altered andesites. By processes of metamorphism the augite and plagioclase components of the original rock have been obliterated and replaced by green amphibole, biotite, chlorite, sericite, feldspar, epidote, zoisite, calcite, quartz, and other secondary minerals. The beds of tuff and agglomerate are usually intermixed with much sedimentary material and gradations to purely sedimentary beds may often be observed. Because of subsequent alteration the original clastic texture of the tuffs is rarely apparent.

In their most altered form the greenstone schists are fine grained and composed largely of chlorite, calcite, and secondary hornblende giving the rocks a dark-green color. These schists, where permeated by mineral-bearing waters, contain considerable amounts of pyrite, and in several places have been bleached to a light yellow, as may be seen on Gravina Island and Cleveland Peninsula.

As shown on the general geologic map, the greenstones are distributed along the mainland belt including Gravina Island, Cleveland Peninsula, and Duncan Canal; they are also well developed along the shores of Hetta Inlet and on Shukwan Island. The greenstones are irregularly involved with the Carboniferous slates, limestones, quartzites, and schists, having been folded and compressed with them, and are considered to be essentially of the same age.

ANDESITES.

The extrusive rocks provisionally referred to the Jura-Cretaceous period are made up of lavas and tuffs like those of the upper Carboniferous. These extrusives include altered andesites, hornblende porphyrites, quartz porphyrites, and basalt tuffs. With these extrusives are included fragmental or clastic rocks composed of volcanic tuffs, sandstones, and conglomerates. As a whole the lavas are less prominent than the clastic rocks. They occur intercalated with the sedimentary slates and sandstones or graywackes. The original character and manner of deposition of extrusives must have been very similar to that of the older greenstones. They are, however, readily 
distinguished from the greenstones by the difference in composition and texture and their dominant reddish color. There is also a difference in the amount of apparent metamorphism of the extrusives of the two eras. The lava and tuff beds of Mesozoic age have not been changed to chlorite or talcose schists and do not show the degree of alteration that is characteristic of the older greenstones. As indicated on the accompanying map, the andesites occupy irregular areas on the south end and along the west coast of Prince of Wales Island, but are not known to occur in other portions of the Ketchikan or Wrangell districts.

\section{BASALTS.}

The Eocene period is also characterized by the extrusion of enormous quantities of basaltic lavas and tuffs. The lava beds have been but little disturbed since their extrusion and show little or no alteration. Had they been folded, compressed, and subjected for a long geologic period to the slowly operating chemical and physical agencies which altered the volcanic rocks of Paleozoic and Mesozoic age, they would undoubtedly resemble the latter closely in general character.

The Eocene basalts are porphyritic rocks ranging in color from gray green to gray black and in composition and texture from basic andesite to a normal basalt. Porphyritic textures are usual, but other textural phases have been developed locally. Amygdaloidal structure, with fillings of quartz, chalcedony, calcite, and a zeolite which is probably stilbite, is characteristic of some beds.

They are mostly dark, fine-grained lavas, the only mineral component visible to the unaided eye being phenocrysts of plagioclase and occasionally pyroxene. The microscope further reveals magnetite and rarely olivine and quartz, also a brown zeolitized glass in several of the thin sections. Alternation products are calcite, epidotite, muscovite, chlorite, and serpentine. Many phenocrysts of feldspar show marked zonal structure and grade in composition from acidic andesite to basic labradorite. In the groundmass the plagioclase is usually more acidic. The feldspars occur in larger amounts than the pyroxene.

These extrusives, as indicated on the geologic map, occupy wide areas on Kuiu and Kupreanof islands. The beds are almost flat lying, being tilted at low angles in places. Columnar structure is a characteristic feature and they may be distinguished from other rocks of the region by their usual red surface weathering.

Interstratified among the lowest beds of this succession are strata of rhyolite tuff, breccia, lava conglomerates, and sandstones. At Port. Camden, on Kuiu Island, narrow seams of coal interstratified with lavas and sandstone contained fossil plant leaves, which are con- 
sidered by paleobotanists to be of Kenai age (upper Eocene). These volcanics overlie the Kenai coal-bearing beds.

Basaltic lavas of postglacial age occupy small areas at various points along the mainland and on Revillagigedo Island. They lie in nearly horizontal beds on the upturned schists and granitic rocks. The massive lava dominates, but narrow beds of tuffaceous material or ash were also observed. These flows correspond to the lavas on Kruzof Island in the Sitka district to the northwest.

\section{OUTLINE OF GEOLOGIC HISTORY.}

The data set forth in the preceding pages are inadequate for the presentation of a complete account of the sequence of events in the Ketchikan and Wrangell districts. In the course of the field work, however, many facts in reference to stratigraphic succession and structure have been obtained, which will be fully used in later reports on this general region. Though the stratigraphy has not been worked out in detail, it does not on the whole appear to be complex except along the boundaries of the Coast Range granitic intrusions, where considerable metamorphism and local disturbanoes of strata havę taken place.

In this province the sedimentary record begins with the deposition of a series of fragmental rocks, now represented by banded quartzite, sandstone, a few beds of conglomerate, and some tuffaceous material. These clastic rocks grade upward into calcareous beds and into limestone containing Silurian fauna. Though the age of the earliest sediments has not been determined, they are believed to be mostly Silurian, as they are succeeded with apparent conformity by limestones of that age. However, since their thickness is estimated at 10,000 feet or more, it is possible that their deposition began in an earlier period. At all events this record shows that sedimentation was probably continuous during early Silurian time, that clastic rocks of great thickness were deposited, and that there was then a gradual deepening of the sea so that several thousand feet of limestone strata were laid down. After the deposition of this Silurian limestone a period of earth movement possibly intervened, during which the rocks were indurated and more or less folded. Of this fact, however, there is no definite proof.

The oldest member of the Devonian is a succession of conglomerate and sandstone beds, composed largely of igneous material, which in most places appear to be less altered than the Silurian limestones and underlying clastic rocks. The pebbles of the conglomerate are embedded in a tuffaceous matrix and were chiefly derived from the older banded quartzite and limestone strata. This series, which is estimated to be 3,000 feet thick, grades upward with ap- 
parent conformity into the lower Devonian limestones. These calcareous beds are nearly 2,000 feet thick and their period of deposition probably extended well up into middle Devonian. In other parts of the region the middle Devonian is represented by argillaceous schists and slaty limestones, but the relations between these and the early Devonian limestones are not known. After deposition of the slaty limestones and argillites and apparently conformable with them a limestone of considerable thickness was laid down in upper Devonian time. This later limestone, though highly crystalline and folded in places, does not generally show the intensity of dynamic action which characterizes the older limestones. At the close of the Devonian volcanic activity began along this coastal belt, and lavas were poured out and tuffs laid down to an estimated thickness of about 800 feet. These volcanics were not observed in the Ketchikan and Wrangell districts but are prominent on Chichagof Island to the north, where they overlie and are interstratified with the upper Devonian limestone beds, indicating that their extrusions were submarine. The evidence from adjacent provinces, notably in the Yukon basin, tends to show that this epoch of volcanism was widespread. The so-called Rampart series of the Yukon appears to belong to the same general epoch as the upper Devonian of southeastern Alaska. Volcanic activity apparently ceased toward the end of the Devonian.

The lower Carboniferous period seems to have been inaugurated by the deposition of gray limestone beds 1,500 feet or more in thickness, and, though the relations between these beds and the underlying volcanics were not definitely determined, it is probable that deep-sea conditions continued from upper Devonian into early Carboniferous time. An unconformity between the lower and the upper Carboniferous is suggested by the occurrence of argillites, sandstones, and conglomerates having a thickness of 200 feet or more. On Kuiu Island these underlie conformably 600 feet of clearly exposed upper Carboniferous limestone, which is broadly folded and shows comparatively little metamorphism. Along the mainland the corresponding limestone beds are interstratified with argillites and crystalline schists and are closely folded and highly metamorphosed. Argillites were extensively laid down at the close of the Carboniferous. A period of volcanic activity ensued resembling that at the end of the Devonian, but of much longer duration. The beds of lava and ash ejected from the volcanic vents were contemporaneous with the slate beds, and because of their intimate association with the sediments the volcanics are regarded as submarine extrusives. They are now represented by the altered massive greenstones and greenstone schists, which are widely exposed throughout the region, and together with the interstratified slate beds have a thickness estimated at about 4,000 feet. 
The sequence of geologic events during the Mesozoic period is not clearly defined because of the lack of paleontologic and structural evidence and because of the great orogenic changes which took place during this era. During early Mesozoic time the bedded rocks suffered intense metamorphism and recrystallization, resulting in the conversion of the sedimentary strata to schists and slates and in the alteration of the volcanic rocks to amphibole schists and chloritic greenstones. At the same time the beds were highly tilted and intricately folded, the direction of the axes of folding being generally southeast-northwest. These changes are exemplified more clearly in the rock beds flanking the Coast Range than in the sedimentaries composing the outer islands. Though early Mesozoic rocks have not been recognized, it is probable, as suggested by Brooks, ${ }^{a}$ that Triassic beds are infolded with these older metamorphosed sediments. The large development of the Triassic deposits to the south in British Columbia points to the same surmise. The only evidence that the Triassic is represented in this region is that a group of fossils found in a piece of limestone float were determined to be Triassic.

During Mesozoic time, the most important event in this district was the intrusion of the great batholiths of the Coast Range. A study of the section across the axial mass of the Coast Range itself shows that the mass is not a simple batholith, but is made up of successive intrusions along the same general line of weakness in the earth's crust. On the outlying islands granitic masses, which are much altered and contain many shearing planes, are invaded by granitic intrusives only slightly altered, which in turn are intruded by pegmatitic dikes and masses. Between these successive intrusions considerable time probably elapsed. The main folding and tilting of the bedded rocks referred to above probably preceded the actual invasion of the granodioritic rocks, as suggested by A. C. Spencer. ${ }^{b}$ This is based on the fact that their lines of intrusion are in a broad way parallel to the bedding planes and schistosity of these older rocks, also on the fact that a few inclusions of schist fragments occur within the intrusive massif. In order to control thus effectively the lines of intrusion of the granodiorites, the invaded sedimentaries must have been highly tilted previous to the time of igneous intrusions.

From observations made in southeastern Alaska and elsewhere it is evident that the geologic processes which combined to produce these vast intrusions and structural phenomena acted very slowly and over long periods of time. Though the Coast Range intrusion is generally considered as having occurred at one period, which is undoubtedly true for limited areas, it is probable that in southeastern Alaska at

"Brooks, A. H., Ketchikan mining district: Prof. Paper U. S. Geol. Survey No. 1, 190, pp. 22-28.

${ }^{b}$ Bull. U. S. Geol. Survey No. 287, 1906, p. 19. 
least considerable time intervened between the first granite invasion and final solidification of the last intrusive masses. Though it is not possible now to refer these granitic intrusions in this province to a definite geologic horizon evidence from adjacent provinces indicates that they continued at least to late middle Jurassic time. These invasions of igneous material were evidently the cause of the vast amount of metamorphism and deformation of the sedimentary strata along their contacts. It is also probable that the formation of many of the ore deposits occurred just after these igneous invasions, the intrusive containing the material for the ore. The transfer of igneous material to points nearer the earth's surface naturally produced strains in the earth's crust which found relief in cracks and fissures and along lines of brecciation, as well as at the contacts of the intrusives. The lines of weakness thus formed furnished channels of free circulation for mineralizing solutions, which are believed to have been derived for the most part from the igneous masses themselves and to have been given off during the process of solidification. ${ }^{a}$

A period of erosion appears to have followed the intrusion of the Mesozoic granite, and later another epoch of volcanism began. The volcanic rocks of this later epoch are represented by tuffaceous deposits and lavas occupying considerable areas in the southern and western parts of Prince of Wales Island, where they lie on the eroded surface of the granite and are followed by or interstratified with deposits of clastic rock. These rocks may be considered equivalent in a general way to the sediments found north of this province on Admiralty Island, where banded calcareous slates carrying lower Cretaceous fossils occur. ${ }^{b}$ The teeply tilted attitude and metamorphosed condition of these volcanics indicate that they were folded after their deposition and induration. The effect of the forces producing these structural phenomena appears not to have been widespread, as it did not modify to any great extent the early Mesozoic folding which preceded the intrusion of the granite.

After the deposition and folding of these Mesozoic strata a long period of quiescence appears to have ensued during which erosion probably was extensive. In late Cretaceous or upper Eocene time sedimentation took place in local basins. These beds including fine conglomerate and shales with some lignite were subsequently tilted and faulted, but this disturbance was apparently local. No evidence of marine life has yet been found in them and it is possible that in this section of Alaska they were fresh-water accumulations. They occur only locally near sea level and in low-lying valleys and basins practically inclosed by mountains of granite and older metamor-

\footnotetext{
a The origin of the ore deposit is more fully discussed in the following pages under the heading of "Ore deposits."

${ }^{b}$ Bull. U. S. Geol. Survey No. 28\%, 1906, p. 144.
} 
phosed rocks. These beds epresent the most recent sedimentary formations of the Wrangell and Ketchikan districts and subsequent to their deposition wide areas of land were flooded by basaltic lavas which poured forth through fissures in enormous volume. These lava flows are flat-lying and on Kuiu Island attain a thickness of over 1,500 feet. They were probably extruded at the close of the Eocene.

A large part of the Tertiary sediments may have been subsequently removed by erosion, for there must have been a long period of quiescence after their deposition and deformation. The next important event in the region was the development of the ice sheet which covered the entire district under consideration. Its retreat left the topography in essentially its present form. After the retreat of the ice some lava sheets were locally erupted.

\section{ORE DEPOSITS.}

\section{GENERAL DISTRIBUTION OF MINERALIZATION.}

In the foregoing pages the geography and geology of the districts have been described, especially with reference to their bearing on the character and distribution of the ore deposits. As a whole the Ketchikan and Wrangell districts owe their present economic importance mainly to the ores of copper, the occurrence of other minerals being commercially of minor significance. Gold alone is mined at several places, but the copper ores afford a more important source of gold. Deposits of silver-lead ores are being developed in both districts, but the production from such properties has been small.

MINERALIZATION IN THE COAST RANGE INTRUSIVE BELT AND ADJACEN'T SCHISTS.

Within the mainland belt, which includes the eastern portion of Revillagigedo Island in the Ketchikan district, mineralization is scattered both in the granitic intrusives and the adjacent schists, but mineralized zones, corresponding to those in the Juneau gold belt to the north, are less strongly marked. Quartz veins and metallic impregnations are found only locally, and prospecting has revealed comparatively few valuable ore deposits in the areas covered by these rocks. Explorations have been confined, however, mainly to the shores of the deep narrow fiords, from which the mountains rise abruptly to high altitudes. Steep, forest-covered slopes make prospecting difficult and have restricted the knowledge of the greater portion of the schist belt to the vicinity of salt water. The ore bodies thus far disclosed have been developed near Smeaton Bay in Behm Canal; at Sealevel, on the northeast side of Thorne Arm; and near 
the head of Carroll Inlet in the Ketchikan district. For the most part they consist of simple veins in fissures and lode deposits of complex composition. They contain only moderate values in gold. In the Wrangell district the schists and argillites near the Coast Range intrusives are less highly metamorphosed than those to the south; moreover, their northwest trend and northeast dip are more uniform. The structural relations resemble somewhat closely those of the $\mathrm{Ju}$ neau district to the north, where distinct belts of mineralization have been traced for many miles. In the Wrangell district such a belt has been observed along and near the contact of the Coast Range granodiorite. The Groundhog and Glacier Basin groups of claims are located in this belt, which is characterized by veins rich in argentiferous galena. Prospects similarly situated with respect to the granite have also been located near Thomas Bay in this district.

\section{MINERALIZATION IN THE SLATE-GREENSTONE BELT.}

Ore bodies of considerable importance have been developed in the slate-greenstone belt, which borders Tongass Narrows, includes the western portion of Cleveland Peninsula, and extends northward along Duncan Canal. They are largely lode deposits or mineralized bands, within which the greenstone-schist country rock has been sheared and fissured and then permeated by the mineral-bearing solutions. In these mineralized bands or lode deposits the country rock has a bleached appearance and is impregnated with small cubes of pyrite and other sulphide ores. Locally narrow seams of massive sulphide ore are found and native gold is often visible in the vein quartz or as thin films or flakes along the jointing cracks and slipping planes. Besides gold and small values in silver, copper also occurs in limited amounts in some of the deposits of these rocks. The principal lode deposits of this type are in the Goldstream mine on the east side of Gravina Island, the Old Glory mine on Cleveland Peninsula, and the prospects on Portage Mountain at the head of Duncan Canal.

Though quartz veins are prominent throughout the slate-greenstone belt, some of which show particles of native gold, most of them are too small or the gold content is too low to pay for mining. Veins of sufficient size to be mined separately have been located at the Gold Standard and Gold Mountain groups of claims on Cleveland Peninsula, at the Hoadley claims 3 miles north of Ketchikan on Revillagigedo Island, and at several points along the east shore of Gravina Island in the Ketchikan district, and on Woewodski Island in the Wrangell district. Gold is the important metal of these vein deposits. 
On Prince of Wales Island the regularity of the rock structure is locally interrupted by the broad and irregular intrusive areas of granitic rocks, and for this reason the ore bodies are not traceable along definite zones. Mineralization in general is closely related to the intrusive rock masses, and many of the deposits are at the contacts of the intrusives, or in their vicinity.

The copper ores generally favor contact aureoles adjacent to the granodiorite or syenite intrusives. They occur as large lenticular bodies and as veins of nearly massive sulphide ore, composed of pyrite, chalcopyrite, magnetite, and pyrrhotite in a matrix of garnet, quartz, calcite, and other gangue minerals. Such deposits are found in the vicinity of Hetta Inlet and on Kasaan Peninsula. Bodies of copper ore inclosed in a greenstone-schist country rock, both in the form of lenticular masses and as veins, occur at Niblack Anchorage, the head of North Arm, and in Hetta Inlet. Bornite and chalcopyrite occur in small patches disseminated locally in the granitic intrusives and are being explored on the Goodro claims to the northeast of Karta Bay.

On Prince of Wales Island gold occurrences are principally confined to the limestones and phyllites and are being mined in the vicinity of Hollis, on Cholmondeley Sound, and at Dolomi. At these points the gold occurs in veins of quartz and in lodes followiing lines of brecciation in the limestone. It is commonly present in the native form and is in many places accompanied by considerable amounts of silver and copper. The principal ore minerals are pyrite, galena, sphalerite, and tetrahedrite.

Auriferous veins in the granitic intrusives have been located and partially developed on Granite Mountain to the west of Karta Bay, at several points in the vicinity of Shakan, and at Ratz Harbor in Clarence Straits. These instances emphasize the fact that the granitic areas are not always barren of ore, as is often presumed.

Ores of silver, lead, and zinc have been observed at several localities on Prince of Wales Island, though the only deposit being developed is on the Moonshine claim, in Cholmondeley Sound. At this place the ore occurs in a well-defined vein traversing the limestone and greenstone schist country rock.

On Dall Island, southwest of Prince of Wales Island, auriferous quartz veins and belts of schists impregnated with gold-bearing sulphides have been partially developed at Dakoo Harbor, 2 miles north of Cape Muzon. Deposits of chalcopyrite ore are being investigated near Sea Otto Harbor, on the west side of the island. At Mount 'Vesta, on the east side, veinlets of tetrahedrite and galena ore occurring in a limestone belt were observed. 
On Baker Island, north of Dall Island, quartz veins in a granitic intrusive belt have been prospected to a large extent, but with little success. Chalcopyrite, associated with pyrrhotite, has been discovered at the granitic contact on the north end of Noyes Island, but is yet to be developed.

The deposits on Coronation Island, which have incited considerable mining interest the last few years, are replacement deposits of galena ore in limestone. They are irregular in occurrence and not of great extent. Granite intrusives were observed in the vicinity and the deposits are probably genetically related to them.

On Kuiu Island, the second largest island in the Wrangell district, metalliferous deposits have not been found. This may be attributed to the absence of intrusive rocks on the island, only one small area, at Washington Harbor, having been observed.

\section{PRINCIPAL CHARACTERISTICS OF ORE DEPOSITS.}

GENERAL STATEMENT.

In the Ketchikan and Wrangell districts four general types of ore deposits have been recognized, vein deposits, breccia veins, lode deposits, and contact deposits, the latter being of greatest importance. Deposits of a character intermediate between these general classes also occur and their peculiar features are discussed in the detailed descriptions. The distinctive characteristics of the different minerals contained in the ore deposits are considered separately under "Character of minerals." Placer deposits, from which the greatest percentage of gold is derived, have not been developed in this section of Alaska.

\section{VEIN DEPOSITS.}

The term "vein deposit" is here applied to any mineral mass or aggregate occupying a fissure or fracture in the rocks. In this region they are usually made up of auriferous quartz and calcite, with a small percentage of metallic sulphides, but veins of nearly massive sulphide ore rich in copper, or in some instances containing lead and silver, are also present. The vein deposits occur in practically all of the older rocks of the district, including the intrusives, but are rarely found in late Mesozoic rocks and have never been observed in the Tertiary sedimentaries or eruptives. These fissures were primarily due to strains in the earth's crust, which may be ascribed to earth movements at present but imperfectly understood. These cavities were natural conduits for the circulation of mineralizing solutions, which contained large amounts of quartz, lime carbonate, metallic sulphides, and other minerals. The solutions were probably heated, and as they ascended through the fissures the conditions of solution changed and the contained minerals were deposited, thus 
forming the veins. The origin of the mineral solutions is speculative, but the intrusive rock masses are probably the source, because there is no evidence of mineral deposits formed previous to their invasion, or in the subsequent rock formations.

In their form and mode of occurrence the veins exhibit much irregularity. Those that traverse the foliation of the schistose country. rock obliquely are in many places more strongly developed and better defined than those that parallel the rock structure. They vary in width from a few inches to 10 feet or more, and are usually less than a thousand feet in horizontal extent, though a few veins are several thousand feet long. It is notable that while portions of a vein contain high values, other portions are practically worthless, and that the richer portions or pay shoots usually follow certain lines pitching at variance with the dip of the vein. Instances of such pay shoots were noted at the Sea Level mine on Revillagigedo Island, at the Gold Standard mine on Cleveland Peninsula, at the Crackerjack mine near Hollis, and at other mines.

Few of the veins show signs of surface oxidation of the minerals. Their croppings expose the unaltered sulphide ore, usually pyrite, and only rarely has this been oxidized to limonite so as to form an iron cap or gossan. Secondary enrichment is entirely absent in the fissure-vein deposits. If such enrichment existed previous to the glacial epoch it was scoured away by the moving ice streams. More recent weathering has affected the rocks to only a slight depth.

- Most of the veins dip steeply or stand nearly vertical. At the time the veins were formed the present outcrops were probably several thousand feet below the earth's surface, and since they were formed from material derived from still greater depths, it may be surmised that similar veins will extend to considerable depths, though individual veins may be cut off by faults or by a gradual wedging of the inclosing fissure.

The walls or country rocks are everywhere considerably altered and in some places consist entirely of metamorphic minerals, including epidote, chlorite, mica, quartz, and calcite. Metallic minerals in many places impregnate the vein walls, and in certain localities the rock adjacent to the vein constitutes a part of the ore.

\section{BRECCIA VEINS.}

The term breccia veins is here used to designate masses of breccia rock occurring in more or less tabular form which have been infiltrated and impregnated by quartz and metallic sulphides. Limestones and schists are the usual inclosing rocks, and in these the veins are either parallel to the bedding planes or crosscut them at narrow angles. 40840-Bull. 347-08-6 
Deposits of this sort are found at Dolomi and in Cholmondeley Sound, on the east side of Prince of Wales Island. At Dolomi the Valparaiso, Paul, and Jessie veins are typical of these brecciated vein deposits, and in Cholmondeley Sound the Gladstone and Equator veins are most typical. These veins range from 2 to 10 feet in width and many of them are traceable for 1,000 feet or more. Quartz forms the cementing material between the brecciated limestone fragments, and to some extent has replaced the rock itself: Sulphide minerals carrying the gold values are contained in the limestone fragments as well as in the quartz, and to a less extent in the unbrecciated rock adjacent to the vein. Because of this replacement of the inclosing rock and the lack of definite walls, it is sometimes difficult to determine the lateral limits of the ore, and assays of the rock are necessary. In some places, as was noted in the Valparaiso vein, the walls are defined by narrow veins of massive quartz 1 to 2 feet in width, with 4 to 6 feet of brecciated ore between. These quartz veins were separated from the intervening breccia by thin seams of gouge matter, indicating movement of the walls subsequent to their deposition. Gold is the principal metal contained in these deposits and is largely free-milling. Pyrite, chalcopyrite, tetrahedrite, galena, sphalerite, and arsenopyrite occur in varying amounts in most. of these veins. Surface weathering has oxidized the surface outcrops, in places to a depth of several feet, forming a gossan composed of limonite, hematite, malachite, azurite, and other minerals. In these breccia veins the richer ore generally occurs in the form of shoots, pitching at an angle to the dip of the vein.

LODE DEPOSITS.

The type of mineral deposit here defined as "lode" consists of bands of schistose rock intersected by veinlets of quartz and calcite and impregnated with metallic sulphides. These lodes may vary from 5 to 50 feet in width, and are usually of great persistence both in length and depth. They invariably follow the structure of the inclosing rock, and the ore is of more uniform grade in them than in the fissure veins. Gold, which is the principal metal in them, is confined largely to the quartz and calcite veinlets. The lode deposits are not so important in this region as in the Juneau district ${ }^{a}$ to the north. This type of mineralization is most prominent in the slategreenstone belt, and ore bodies of this sort are being mined at the Keystone claim on Cleveland Peninsula and at the Goldstream mine on Gravina Island. At these localities the inclosing rock is a greenstone schist, which within the lodes is changed to a soft grayish or pale-greenish rock, consisting chiefly of carbonates of lime and mag-

${ }^{a}$ Spencer, A. C., The Juneau gold belt : Bull. U. S. Geol. Survey No. 287, 1906. 
nesia, with sericite and some chlorite. The metallic sulphides, essentially pyrite with some chalcopyrite, are finely disseminated throughout the rock and amount to about 3 to 6 per cent. The lateral limits of the deposits are not sharply defined, and in the altered country rock the mineralized portion gradually changes to the unmineralized schist.

The origin of the lode deposits is believed to have been similar to that of the fissure veins. Mineral solutions of magmatic origin permeated and altered the schists, and deposited in them the sulphide minerals. The rocks were then fractured and veinlets or stringers of quartz and calcite were deposited. Subsequent movements have caused slipping and shearing planes within the lodes, but large transverse faults were not observed.

Surface waters and other surface agencies have had practically no effect upon this type of deposit since the glacial epoch, and secondary. enrichment does not occur.

CONTACT-METAMORPHIC DEPOSITS.

Among the most valuable mineral deposits in the region are the contact metamorphic deposits, which are largely developed on Prince of Wales Island. This term is here restricted to those mineral veins or ore masses which have been formed by contact metamorphic agencies and which carry the minerals characteristic of such action. A contact metamorphic deposit must, therefore, be in the vicinity of an intrusive rock but not necessarily at its contact. Such deposits occur mostly in limestone or calcareous rocks usually within 1,000 feet of the intrusive rock masses. They are believed to be of magmatic origin and to have been formed by gaseous and aqueous emanations given off from the igneous intrusive during cooling and solidification. As lime carbonate is a ready precipitant of these mineral solutions, the largest ore masses are usually formed at points where limestone is the intruded rock.

The characteristic minerals associated with the contact metamorphic deposits are chalcopyrite, pyrrhotite, pyrite, and magnetite in a gangue of garnet, epidote, calcite, quartz, amphibole, wollastonite, and several rare minerals. These minerals are admittedly the typical products of contact metamorphism, and their nature and intergrowth show that they result from the action of hot solutions. Mineralogically they differ from the ores of other deposits, especially in the contemporaneous formation of oxides and sulphides, principally of iron, and in their association with the various lime-silicate minerals enumerated above. Within these contact aureoles the mineral deposits assume many forms. They occur not only as veins 
filling fissures a few hundred feet in length, crosscutting the intruded rock beds, but also in the intrusive mass itself, and as banded replacement deposits, where mineral deposition has taken place along the bedding planes of a quartzite country rock and the intervening bands have been more or less completely replaced by vein material. Of greatest importance, however, are the masses composed largely of metallic sulphides and magnetite. These ore bodies are irregular masses ranging from 20 to 200 feet in lateral dimensions and from 100 to 300 feet in depth. Such deposits are largely developed at Copper Mountain and on Kasaan Peninsula, both localities on Prince of Wales Island, and their characteristics are discussed under the detailed descriptions.

\section{CHARACTER OF ORES.}

The important ores of the Ketchikan and Wrangell districts are not of great variety and their association is not unlike that of the other lode-mining areas in Alaska. Most of the ores are primary sulphides; the only recognized ores of secondary origin which occur in commercial amounts are the copper carbonates at Copper Mountain.

\section{COPPER ORES.}

The principal copper mines in the region are developing deposits of a low-grade copper-iron sulphide ore which can be profitably exploited only by extreme economy in extraction. In certain instances the accessory gold content of $\$ 1$ and $\$ 2$ is depended on to raise the total value of the ore above the commercial limit. The copper ores generally contain high percentages of iron and lime and are classed as "base ores" by the smelters. Therefore, to acomplish their reduction, it is necessary to mix them with siliceous or quartz ores. The lack of available siliceous ore has been a serious handicap to the smelters of the district. Increasing the value of the copper ores by concentration alone would in most cases be of little advantage, both because of the high percentage of iron minerals and because only the lighter siliceous minerals would be separated, which are necessary as a flux. In some instances, however, a grinding and treatment of the ores in a magnetic separator might be done to advantage.

These facts are clearly brought out in the following table, which shows the composition of the gangue content of the ores from the principal mines, as determined by smelter assays. 
Smelter assays of ores from copper mines in the Ketchikan district. ${ }^{a}$

\begin{tabular}{|c|c|c|c|c|c|c|c|}
\hline Name of mine. & $\underset{\text { (silica). }}{\mathrm{SiO}_{2}}$ & $\underset{\text { (iron). }}{F e}$ & $\begin{array}{c}\mathrm{CaO} \\
\text { (lime). }\end{array}$ & $\begin{array}{c}\mathbf{S} \\
\text { (sulphur). }\end{array}$ & $\begin{array}{c}\mathrm{Al}_{2} \mathrm{O}_{3} \\
\text { (alu- } \\
\text { mina). }\end{array}$ & $\begin{array}{c}\mathrm{MgO} \\
\text { (mag- } \\
\text { nesia). }\end{array}$ & $\underset{\text { (zinc) }}{\mathrm{Zn}}$ \\
\hline $\begin{array}{l}\text { Mamie mine: } \\
\text { Siliceous }\end{array}$ & \multirow{8}{*}{$\begin{array}{l}30.6 \\
10.6 \\
16.4 \\
15.2 \\
16.5 \\
19.6 \\
27.2 \\
41.8 \\
12.0 \\
74.2\end{array}$} & \multirow{8}{*}{$\begin{array}{r}17.5 \\
47.8 \\
34.1 \\
42.8 \\
35.6 \\
28.3 \\
24.6 \\
18.4 \\
37.0 \\
8.6\end{array}$} & \multirow{8}{*}{$\begin{array}{r}10.4 \\
2.7 \\
7.6 \\
.4 \\
6.8 \\
7.0 \\
1.0 \\
1.7 \\
1.2 \\
1.8\end{array}$} & \multirow{8}{*}{$\begin{array}{r}5.9 \\
6.3 \\
6.9 \\
4.3 \\
6.2 \\
8.0 \\
22.8 \\
14.8 \\
41.0 \\
7.4\end{array}$} & \multirow{4}{*}{$\begin{array}{r}17.2 \\
7.7 \\
11.7\end{array}$} & & \\
\hline Base & & & & & & & $\ldots--$. \\
\hline Stev & & & & & & & \\
\hline Mount & & & & & & & \\
\hline Karta Bay m & & & & & $\cdots$ & & \\
\hline Niblack mine_ & & & & & $\begin{array}{l}5.6 \\
7.8\end{array}$ & 1.2 & 1.0 \\
\hline Omar & & & & & 4.0 & $\operatorname{Tr}$. & \\
\hline Gonoer Mour & & & & & 1.1 & & \\
\hline $\begin{array}{l}\text { Oopper Mountai } \\
\text { face ore }\end{array}$ & & & 12 & . 3 & 12.0 & & \\
\hline Oopper Oity mi & 12.4 & 27.2 & 1.6 & 22.6 & 4.86 & & 8.4 \\
\hline
\end{tabular}

a The above assays were kindly furrished to the writers by the Alaska Smelting and Refining Company and by the Tacoma Smelter.

The preceding analyses, though incomplete, show the relative basic and siliceous content of the ores. The portion of the analyses not given represents the moisture $\left(\mathrm{H}_{2} \mathrm{O}\right)$, the carbon dioxide $\left(\mathrm{CO}_{2}\right)$, the undetermined elements, including the alkalies contained in the ores, and also their content of precious metals.

GOLD ORES.

Although gold is distributed through all the older rock formations within the region, the localities which show sufficient concentration of auriferous minerals to make workable ore bodies are relatively few, and the values found are usually low. The low cost of transportation and the available water power, however, make it possible at many places to extract the ores at a profit.

The gold mines operating in the Ketchikan and Wrangell districts are producing a free-milling ore, i. e., an ore from which the greater percentage of the gold content may be extracted by amalgamation. Some of these ores have been shipped to the smelter, but unless the charges for reduction are exceptionally low it would appear that the ores should be concentrated and these concentrates alone shipped to the smelter. The amount of concentrates derived from the gold ores seldom exceed 5 per cent.

\section{ORE MINERALS.}

NATIVE MINERALS.

Gold.-Gold, the only native metal found in commercial quantities, occurs in vein and lode deposits. Small quantities of gold are also present in the alluvium, notably that of Stikine and Unuk rivers. Visible particles of gold are scattered through the vein quartz and associated with pyrite to some extent in the adjacent country rock at Crackerjack and Puyallup mines near Hollis, at the Gold Standard 
mine on Cleveland Peninsula, at the Hoadley group just north of Ketchikan, at Sealevel in Thorne Arm, and at other points. Gold is also found in small particles associated with galena and spthalerite in narrow seams and in the form of thin flakes along jointing and slipping planes in the lode deposits at the Gold Stream mine and other localities. In the breccia deposits at Dolomi many of the veins show native göld associated with secondary minerals, such as limonite, malachite, and azurite, apparently derived from original sulphide ores by weathering. In many of the deposits, however, the gold is contained largely in sulphide minerals, and its association with the sulphide, usually pyrite, is so intimate that fine milling and amalgamation fail to extract the metal. Many of the sulphide concentrates from these ores contain from 5 to 10 ounces of gold.

Copper--Metallic copper was observed at the surface croppings of the copper deposits at the head of Duncan Canal, at Copper Mountain, at Skowl Arm, at Cholmondeley Sound, and on Kasaan Peninsula. In this relatively rare mode of occurrence the copper is in thin sheets along clay seams or slipping planes and has been derived from the alteration of chalcopyrite.

SULPHIDES, TELLURIDES, ARSENIDES, ETC.

Chalcopyrite.-Chalcopyrite, which forms the bulk of the copper ores of the districts in all the various types of deposits, is composed of the sulphides of copper and iron and when pure contains 34.5 per cent of copper. It occurs associated with pyrite, pyrrhotite, and magnetite in a gouge composed of garnet, epidote, quartz, calcite, and amphibole minerals and in quartz veins with galena and zine blende. Chalcopyrite associated with biotite and amphibole has also been found finely disseminated in the intrusive rocks, but in these cases it was evidently not an original mineral of the rock.

As platinum has been found in association with chalcopyrite ores elsewhere, it seemed desirable to test these ores for this metal as well as for their gold content. Large samples of chalcopyrite ore as nearly pure as possible were taken from three mines and analyzed by Mr. Locke with the following results:

Analyses of chalcopyrite ores.

[Analyst, Locke.]

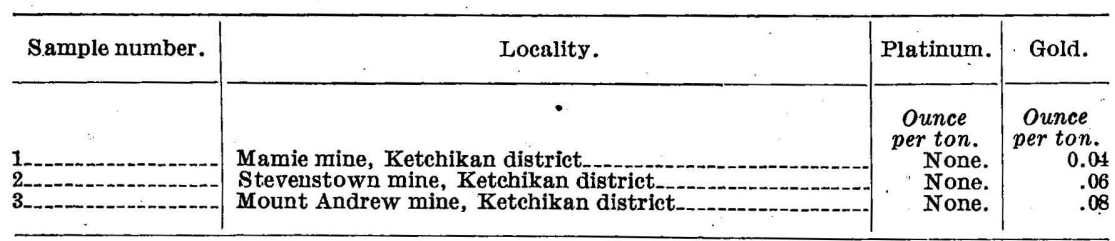


These analyses did not reveal a perceptible amount of platinum in the chalcopyrite, yet showed a gold value of from $\$ 0.80$ to $\$ 1.60$ per ton.

Bornite.-Bornite is also a copper-iron sulphide containing 55.5 per cent copper, and may be easily recognized by its iridescent or copper-red color. It has been found only ai the Goodro prospects on Prince of Wales Island, where it is distributed in small particles and masses associated with chalcopyrite, secondary biotite, and epidote near the contact of a basic dioritic intrusive.

Pyrite.-The most common metallic sulphide known in the region is pyrite. It is present in the form of small but perfect cubes throughout the metamorphic schists, slates, and greenstones, and is finely disseminated in the igneous rocks. Alone it is of little commercial value, but where associated with gold it may form a valuable ore. Auriferous pyrite, which constitutes the larger percentage of the ore concentrates, is supposed to be a mechanical combination by which the gold is distributed throughout the pyrite in minute films and particles, which, however, can not be separated by the usual method of amalgamation. Pyrite in a pure state contains 53.4 per cent of sulphur and is the raw material for the manufacture of sulphuric acid. At one locality, Skowl Arm, where large bodies of this sulphide occur, the advisability of mining"pyrite for its sulphur content, which amounts to about 40 per cent, is being considered.

Pyrrhotite.-The mode of occurrence of pyrrhotite is similar to that of pyrite, but it is not so broadly distributed. It is a sulphide of iron containing less sulphur than pyrite and may be distinguished by its darker bronzelike color and its magnetic properties. Pyrrhotite is largely developed in all of the copper contact metamorphic deposits and occurs finely disseminated in the intrusives near their contacts.

Some pyrrhotite ores elsewhere contain nickel in sufficient amount to form a nickel ore. For this reason and because some masses of this mineral were reported to contain large amounts of cobalt, samples of nearly pure pyrrhctite were taken from three localities and submitted for the determination of their nickel, cobalt, platinum, and gold content, with the following results:

Analyses of pyrrhotite ores.

[Analyst, George Steiger, U. S. Geological Survey.]

\begin{tabular}{|c|c|c|c|c|c|}
\hline Sample number. & Locality. & Nickel. & Cobalt. & Platinum. & Gold. \\
\hline 4 & \multirow{3}{*}{$\begin{array}{l}\text { Brown and Metz claim, north end } \\
\text { Noves Island, Ketchikan district. } \\
\text { Sultana claim, north side Hetta } \\
\text { Inlet, Ketchikan district. } \\
\text { Iron Orown claim, Copper Moun- } \\
\text { tain, Ketchikan district. }\end{array}$} & \multirow{3}{*}{$\begin{array}{l}\text { Per cent. } \\
0.1 \text { to } 0.2 \\
.1 \text { to } .2 \\
.1 \text { to } .2\end{array}$} & \multirow{3}{*}{$\begin{array}{l}\text { Trace. } \\
\text { Trace. } \\
\text { Trace. }\end{array}$} & \multirow{3}{*}{$\begin{array}{l}\text { Ounces } \\
\text { per ton. } \\
\text { None. } \\
\text { None. } \\
\text { None. }\end{array}$} & \multirow{3}{*}{$\begin{array}{r}\text { Ounces } \\
\text { per ton. } \\
\text { None. } \\
\text { None. } \\
\text { None. }\end{array}$} \\
\hline 5--- & & & & & \\
\hline 6------ & & & & & \\
\hline
\end{tabular}


Galena.-The lead sulphide, galena, containing 86 per cent of lead and usually a small amount of silver, has been found at several localities. It occurs with sphalerite, pyrite, and tetrahedrite, and also with silver and gold in small amounts. Galena is the principal ore of the Moonshine prospect on Cholmondeley Sound, and at the Groundhog and Glacier basin prospects on the mainland east of Wrangell. At the Moonshine group of claims it occurs both in a. coarse crystalline state and in a fine compact state, the latter being called "steel galena." To determine the relative amounts of silver contained in the two varieties the mine owners took samples which were assayed with the following results: ${ }^{a}$

Analyses of galena.

\begin{tabular}{|c|c|c|c|}
\hline & $\ldots$ & Silver. & Lead. \\
\hline $\begin{array}{l}\text { Fine-grained compact galena ore } \\
\text { Coarse-grained galena ore }\end{array}$ & - & $\begin{array}{r}\text { Ounces } \\
\text { per ton. } \\
17.6 \\
21.2\end{array}$ & $\begin{array}{r}\text { Per cent. } \\
66.6 \\
78.9\end{array}$ \\
\hline
\end{tabular}

The lead-silver ratio is practically the same in both cases. Galena also occurs in variable amounts, usually small, associated with the gold ores, at Dolomi, on Annette and Gravina islands, on Cleveland Peninsula, and at Thomas Bay. It is rarely present in the copper contact deposits.

Sphalerite.-The mineral sphalerite, commonly known as zinc blende or black jack, occurs under practically the same conditions as galena, with which it is usually associated, but at no place has it been found in sufficient quantity to make a zinc ore. Besides the localities mentioned where galena occurs it has been found in considerable amounts at some prospects on Beaver Mountain in Hetta Inlet and is present in the copper ores at Niblack and Copper City.

Tetrahedrite.-Gray copper ore, as tetrahedrite is usually termed, is a copper-antimony sulphide which may be distinguished from sphalerite by its lack of cleavage and its dark brown to black streak. It has been found at Dolomi, on Annette Island and on Kasaan Peninsula associated with chalcopyrite, pyrite, galena, and sphalerite in the quartz veins inclosed in limestone. Tetrahedrite, though a copper ore, was not observed in the copper deposits, and it is important only because of the gold and silver which usually accompany it.

Tetradymite.-A telluride of bismuth, called tetradymite, occurs with the gold ores at the Hoadley claims north of Ketchikan and at the mines on Cleveland Peninsula. It is a relatively rare mineral of a steel-gray color with a perfect basal cleavage and usually a

"These analyses were kindly furnished to the writer by Mr. Catlin, of Ketchikan. 
prismatic form. It has been confused by the miners with petzite, the gold-silver telluride; a mineral which has not been observed in the region, though it may be present in some of the gold ores.

Arsenopyrite.-A sulpharsenide of iron, called arsenopyrite, was observed in the quartz veins at several localities in small and unimportant amounts. It may be distinguished from pyrite by its silverwhite color. At the prospects in Thomas Bay it is found in considerable quantities containing gold values, and is associated with pyrite, galena, and some sphalerite.

Molybdenite.-Flakes of molybdenite, molybdenum sulphide, are found in some of the quartz veinlets occurring in the metamorphic schists and the intrusives of the mainland. It also occurs in small amounts in some of the contact metamorphic deposits on Prince of Wales Island. A small vein showing a considerable amount of this sulphide was observed in the schists on the north end of Noyes Island. Molybdenite is one of the rare minerals of this region, and so far as known does not occur in commercial amounts. It is a soft, flaky mineral with metallic luster resembling graphite, but having a bluer tinge.

OXIDES, CARBoNATES, AND SILICATES.

Magnetite.-The principal occurrence of the magnetic oxide of iron is in association with the copper deposits. At the copper mines in Kasaan Peninsula magnetite forms about half of the ore mass and occurs in large amounts in some of the deposits in the vicinity of Hetta Inlet. Minute grains and small octahedral crystals of magnetite occur scattered through the ferromagnesian silicates and less plentifully through the groundmass as an accessory constituent of the dioritic intrusives and the greenstones. Magnetite was not observed in the quartz veins, though it is present in many of the pegmatite dikes. At several places on Prince of Wales Island magnetite occurs in masses sufficiently high in grade to make an iron ore, though no attempt has been made to mine it as such. The presence of chalcopyrite in these magnetite masses makes them important as copperbearing deposits, though in many instances the content of the metal is not sufficient to insure profitable mining. The mode of occurrence of the magnetite, associated in masses with chalcopyrite and pyrite, shows that it was deposited under similar conditions, and that it is a primary ore mineral, as the latter evidently are. In the intrusives, however, it is apparently an original constituent of the rock.

Hematite.-Hematite, also an oxide of iron, occurs in the form of specularite or micaceous hematite in the contact copper deposits, though only in minute scattered grains. At the Niblack mine it forms small masses accompanied by quartz in the ore bodies. It was not observed associated with the auriferous ores. 
Limonite.-The hydrous iron oxide called limonite is an alteration product of iron minerals, most commonly of pyrite, and is found at many places, but nowhere in quantity. It occurs-with the coppercarbonate ores on Copper Mountain and forms a shallow capping on many of the pyritic ore deposits.

. Malachite.-The green carbonate of copper called malachite is usually found in small amounts at the croppings of the copper deposits where limestone forms the inclosing rock. Its principal occurrence is on Copper Mountain, where surface alteration has been extensive and formed small masses of this carbonate ore in the garnetiferous and limestone gangue. The mode of occurrence is mostly in narrow seams or veinlets and as an incrustation or coating on the sulphide ores. Malachite is associated with limonite, chrysocolla, and small amounts of azurite. Its high copper content and the facility with which it may be reduced make it a very valuable ore.

Azurite.-Azurite, like malachite, is a carbonate of copper, but is distinguished by its deep-blue color. Only small amounts of this ore were observed, and it was always in association with malachite as a surficial alteration product of the sulphide copper ores.

Chrysocolla.-The hydrous silicate of copper, called chrysocolla, like malachite and azurite, has been found in quantity only at the Copper Mountain mine, where it is apparently confined to the surface workings and is of only minor importance as an ore.

Quartz.-Quartz is the most common and most important gangue mineral in both the fissure and the lode deposits. It usually occurs as massive quartz and rarely in the form of crystals. At Dolomi in the veins along lines of brecciation in the limestone it forms the cementing material and has replaced to a large extent the surrounded fragments of the limestone. At Niblack in the copper deposits it is associated with small amounts of hematite and forms what is termed "jasper ore." In the contact metamorphic deposits it is present in only small amounts, generally crystallized and associated with epidote and garnet. Many of the crystals are doubly terminated and from 1 to 10 centimeters in length, many of them being twinned. They have formed subsequent to the crystallization of the epidote and garnet and are superimposed on them.

Calcite-Calcium carbonate, commonly known as carbonate of lime, has the most widespread occurrence of any gangue mineral except quartz. It is readily recognized by its perfect cleavage and its softness. Calcite is particularly prominent in the contact metamorphic deposits and is associated with the galena ores. Where it was observed occurring with garnet and epidote it was invariably of later formation.

Garnet.-In the Ketchikan district garnet forms the principal gangue mineral of the contact-metamorphic deposits and is confined 
for the most part to the altered limestones near the intrusive contacts. Though it commonly occurs in massive form, it also appears in crystal aggregates usually of dodecahedral form embedded in the altered limestone. The separate crystals in cross section show a concentric structure resembling banded agate, being made up of green and red bands, which probably represent a slight change in composition during the growth of the crystals. In size the crystals range from 1 to 5 centimeters in diameter, the faces showing a subadamantine luster, though in mass the garnet has the usual luster. To determine the variety of this garnet rock a sample was submitted for analysis, and the results, which. were determined by W. T. Schaller, of the United States Geological Survey, are compared in the following table with garnet rock from other localities:

Analyses of garnet occurring in contact metamorphic deposits.

[Analysts: W. T. Schaller, 1 ; George Steiger, 2-4.]

\begin{tabular}{|c|c|c|c|c|c|c|}
\hline & 1. & 2. & 3. & 4. & 5. & 6. \\
\hline \multirow{9}{*}{ 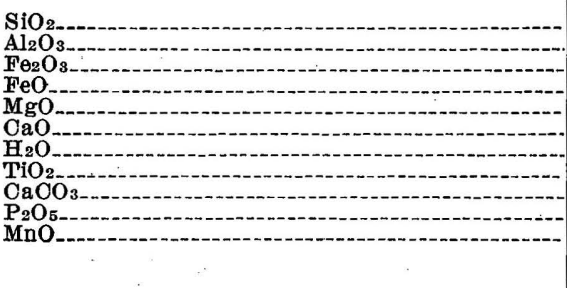 } & $\begin{array}{r}35.18 \\
5.15\end{array}$ & $\begin{array}{l}36.26 \\
78\end{array}$ & $\begin{array}{l}37.79 \\
11.97\end{array}$ & $\begin{array}{r}37.15 \\
6.08\end{array}$ & 35.5 & $\begin{array}{l}40.0 \\
22.7\end{array}$ \\
\hline & 25.05 & 32.43 & $\begin{array}{l}11.97 \\
15.77\end{array}$ & $\begin{array}{r}0.98 \\
19.40\end{array}$ & 31.5 & \\
\hline & .40 & .32 & 1.31 & & & - \\
\hline & $\begin{array}{r}.09 \\
33.36\end{array}$ & None. & $\begin{array}{r}.37 \\
32.57\end{array}$ & 3244 & 330 & 37.3 \\
\hline & & & .09 & & & \\
\hline & None. & None. & & & & \\
\hline & & None. & $-\cdots$ & 4.20 & --- & |------' \\
\hline & & .27 & .31 & & -0 & - \\
\hline & 99.65 & 100.36 & 100.18 & 100.60 & 100.0 & 100.0 \\
\hline
\end{tabular}

1. Garnet rock, Jumbo mine, Prince of Wales Island.

2. Garnet, Morenci, Ariz., Prof. Paper U. S. Geol. Survey No. 43, p. 134.

3. Massive brown garnet, White Knob, Idaho: Economic Geology, vol. 2, No. 1, p. 7.

4. Garnet, San Jose, Mexico : Trans. Am. Inst. Min. Eng., vol. 36, p. 92.

5. Typical composition of andradite.

6. Typical composition of grossularite.

From the above analyses it is evident that the greater per cent of the garnet associated with the contact-metamorphic deposits is andradite and not grossularite, as has in many instances been supposed.

The garnet masses are confined principally to the intrusive contacts with a limestone of nearly pure calcium carbonate, thus suggesting that a vast amount of foreign material must have been brought in along the intrusive contacts to have produced the garnet masses. Where the intrusives invade a quartzite country rock, the garnet forms bands interstratifying the siliceous beds, and many of these mineral bands extend thousands of feet from the contacts. At Copper Mountain this mineral forms a massive belt 20 to 50 feet wide between the intrusive diorite and the limestone country rock, and occurs in veins crosscutting the limestone beds and penetrating the intrusive rock. Included in the garnet masses are crystallized particles and small masses of chalcopyrite, magnetite, pyrrhotite, and 
rarely pyrite, all of which, combined as they are, constitute the copper ore.

The almandite variety of garnet occurs in great abundance in the mica and chlorite schist near the mouth of the Stikine River. The crystals are from 1 to 4 centimeters in diameter, usually of dodecahedral form, with trapezohedral truncations. Though abundant, this mineral has not been extensively cut as a gem stone on account of its being too opaque and because of numerous fractures or flaws in the crystals.

Epidote.-A calcium-iron-aluminum silicate, called epidote, occurs largely as an alteration product in the igneous rocks and as a gangue mineral in the contact-metamorphic deposits. As a mineral due to contact metamorphism it forms many large crystals associated with garnet quartz and calcite. Specimens of this mineral from the Green Monster copper claims were sent to the Harvard mineralogical laboratory by Mr. W. C. Hart and have been described by Dr. Charles Palache. $^{a}$

Wollastonite.-The metasilicate of calcium, wollastonite, was found forming radiating crystal clusters in the limestone and quartzites a short distance from but not at the intrusive contact. It belongs with the contact-metamorphic minerals of the region, but its occurrence away from the contact suggests that the conditions necessary for its formation were not so intense as those required to produce the garnet and epidote which occur at the contacts.

Scapolite.-Like wollastonite, scapolite occurs in the vicinity of the ore deposits and is a calcium-aluminum silicate containing soda and chlorine. It occurs in prismatic crystals an inch or two in length with rough, uneven faces and is from white to gray in color. It was found only in the vicinity of the Copper Mountain deposits and is not of common occurrence.

Amphibole.-The hornblende variety of amphibole, a calcium-magnesium-iron silicate, is a prominent gangue mineral in some of the contact-metamorphic deposits. At the Stevenstown mine it was observed to form radiating crystal clusters in the inclosing altered schists and was intimately associated with garnet and chalcopyrite. It is also present in the ore deposits at the Mount Andrew and Mamie mines. The tremolite variety, calcium-magnesium silicate, occurs as a metamorphic mineral in some of the limestone beds, notably in the Ham Island marble deposits in the Wrangell district.

Feldspar.-The presence of feldspar in small amounts was noted in several of the vein deposits, more especially in those occurring in the band of crystalline schists, and is of interest because of its probable relation to the granitic intrusives. The variety is mainly that

a Proc. Am. Acad. Arts Sci., vol. 37, No. 19, March, 1902, pp. 531-535. 
of albite, which occurs in the quartz veins on the Lon de Van claims at the head of George Inlet, at the Birdseye claim to the south of Ketchikan, and at other localities. At the Goodro prospects near Karta Bay albite is found as a vein mineral in the copper deposits associated with secondary biotite and epidote.

Biotite.-Flakes of biotite, commonly termed black mica, were noted rarely in some of the vein deposits. At the Lon de Van prospect mentioned above it is associated with secondary albite and at the Goodro prospects it is a prominent mineral constituent of the copper ores. Its presence in these deposits suggests that conditions of moderately high temperature existed. during the ore deposition.

Clinochlore.-Clinochlore, a soft bluish-green micaceous mineral, was observed in considerable amounts occupying small druses and finely disseminated in some of the copper-bearing magnetite deposits on Kasaan Peninsula.

\section{DETAILED DESCRIPTIONS OF MINES AND PROSPECTS.}

\section{GENERAL STATEMENT.}

A great many prospects and mine workings of moderate extent are located in the Ketchikan district, but the developed and producing mines are few. During the few months devoted to field work in this region nearly 200 localities were examined, including all of the important mines and prospects. In the following descriptions the properties are grouped first according to their chief metal content and then taken up in geographic order. Copper is and probably will be the principal metal product of the district and is therefore considered first, followed by gold and the less important metals. The geology of the region as a whole, the relations of the ore deposits, and the mode of occurrence of the minerals have been discussed in the foregoing pages, and while consulting the following detailed descriptions these general descriptions should be kept in mind. In the following pages one of the principal typical deposits of a locality is generally selected and described in considerable detail, and the other deposits are next discussed according to their importance and the degree in which they vary from the type deposit. At the close of these descriptions the building stones and the mineral and thermal springs are discussed briefly.

\section{COPPER MINES.}

GENERAL STATEMENT.

Copper does not occur uniformly throughout the districts. Irregular lenses or masses of the ore are present in the altered greenstone schists at Niblack; in the vicinity of Copper Mountain and on Kasaan Peninsula they are found at the contact of granitic intrusives with 
limestone and siliceous schists, and veins of nearly massive sulphide ore occur in a belt of slate-greenstone schist along the shores of Hetta Inlet and at the head of North Arm. In a general way these ore bodies are so irregular that the rule to observe in exploitation is to follow the ore and not drive long crosscut tunnels with the expectation of undercutting the deposit in depth. The bulk of the copper ore is chalcopyrite and cupriferous pyrite, accompanied by magnetite, pyrrhotite, and other sulphide minerals. With one exception, carbonate and oxide ores are practically absent, and the zone of secondary concentration or surface enrichment, prominent in most copper deposits, is wanting or is too small in extent to be important. In general it may be stated that where a sulphide ore is being mined in these districts the values in the ore will not decrease rapidly with increasing depth.

\section{HETTA INLET.}

GENERAL DESCRIPTION.

All of the most important discoveries on the west coast of Prince of Wales Island are contiguous to Hetta Inlet, a deep embayment which is connected with the Pacific Ocean through Cordova Bay (see Pl. I). The increasing importance of this area led to the survey of the waterways from the head of Hetta Inlet to the Pacific Ocean during the early part of 1905 by the Coast and Geodetic Survey. With the aid of the chart of this section ocean-going steamers may approach Coppermount and Sulzer with safety.

The head of Hetta Inlet is separated from the west arm of Cholmondeley Sound by a low divide 4 miles across and less than 200 feet high. The Government has built a roadway between the two waterways which permits the shipment of light freight and increases the mail facilities over this relatively short route from Ketchikan to Sulzer and Coppermount. Heavy freight and supplies are delivered by vessels from Puget Sound, which occasionally call at the mining camps along the inlet, and by small steamers from Ketchikan, a distance of 100 miles by water.

The shores of Hetta Inlet, like other parts of the coast, rise precipitously from the water's edge, and the main channel and the harbors are deep. The steep mountains terminate in peaks from 2,500 to 3,800 feet in elevation, many being less than than a mile from tide water. A luxuriant growth of timber and vegetation extends to an altitude of 2,000 to 2,500 feet, and above this the mountains are bare, permitting broad views of the surrounding region. Many inland lakes are included in the area, and their outflowing streams furnish abundant water power the year around. This advantage and the accessible supply of timber are exceptionally favorable for mining. 
GEOLOGY.

The accompanying sketch map presents the geologic relations as well as the positions of the mines (Pl. IX). An intrusive stock or boss of granodiorite 8 miles wide occupies the centra! part of the field and is surrounded by irregular areas of limestone and quartzite. The geologic age of these bedded rocks is Paleozoic. The determination is based wholly on their lithologic and structural features, as no fossil evidence was obtained. The limestone has been so completely metamorphosed to coarsely crystalline marble that its bedding planes are no longer apparent. The quartzites, which have a schistose and wrinkled structure, overlie the limestone and are in turn overlain by a wide belt of greenstone schists, which border the shores of Hetta Inlet. The general strike is $\mathrm{N} .15^{\circ}$ to $45^{\circ} \mathrm{W}$., and the dip is steep to the west, though this has been interrupted in the vicinity of the intrusive granite boss where the stratified rock beds are usually parallel to its contact. Small areas or patches of limestone occur within the granodiorite area where erosion was not sufficient to remove them. The coarsely crystalline character of the intrusive and the alteration of the limestone at points distant from the contact indicate that these rocks were deeply buried at the time of metamorphism and are a measure of the extent of subsequent erosion.

After the erosion of the granodiorite and after the deposition of the ore bodies, dikes, usually narrow, of diabase and diorite-porphyrite were injected. These dikes have no bearing upon the vein deposits except at those places where they crosscut them along lines of fracture, as at the Copper City and Corbin mines.

ORE DফৃPOSITS.

Distribution.-The principal ore bodies in Hetta Inlet are on the Copper Mountain, Jumbo, Houghton, and Green Monster groups of claims, and are contact metamorphic deposits, confined principally to the aureole of the granodiorite in either limestone or quartzite. The deposits at the Corbin and Copper City mines are vein deposits of massive sulphide ore in the outlying greenstone schists which border the shore of Hetta Inlet.

Effects of contact metamorphism.-The intrusion of the granodiorite batholith appears to have affected an alteration of the adjacent sediments for only a few thousand feet from the contact. Nearer the contact the influence of this intrusive on the stratified rocks is evident only in the quartzite or schistose beds by the development of wollastonite and some garnet and epidote, while the crystalline limestone strata are apparently unaltered. These facts go to show that regional metamorphism previous to the granodiorite intrusion was apparently so intense as to render the rocks little susceptible to further changes. 
The changes within the contact aureole due to the indirect effect of the intrusive mass or hydrothermal metamorphism were caused by. the vapors and liquid solutions emanating from the igneous magma during the period of its solidification. In the present instance this action has extended much farther than the direct contact metamorphism and has produced wide deposits and veins of garnet and epidote in which the ores occur. The mineral-bearing solutions given off from the unsolidified portions of the igneous masses penetrated the adjacent limestone and quartzite beds, mainly along the granodiorite contact, dissolving channels into the limestone, though often taking advantage of preexisting fissures in both the limestone and granodiorite. During their ascent the thermic and other conditions of the aqueous solutions changed and their mineral contents were precipitated by the limestone and meteoric waters and gradually filled the channels and fissures. The contact metamorphic deposits thus formed are composed essentially of a massive garnet-epidote rock, varying from a reddish to a greenish color, in which grains of chalcopyrite, pyrrhotite, and magnetite are disseminated. In places the rock has a decided granular texture, both the garnet and the epidote having their crystalline forms, and in this the sulphide ore is usually found in small masses accompanied by calcite and quartzite. The width of the contact metamorphic deposits ranges from 25 to 250 feet and the inclosing walls are sharply limited where formed of limestone, but the altered quartzite boundaries were less well defined. Smaller bodies of this vein material are found in fissures branching from the contact both into the limestone and into the granodiorite, the lateral extent of these being usually less than 1,000 feet: A description of both the ore and the gangue minerals found in these deposits is contained in this report under the heading "Ore minerals" (p. 85).

COPPER MOUNTAIN GROUP.

General description.-The Copper Mountain group of claims of the Alaska Copper Company stretches northward from tide water at Copper Harbor across the crest line of a ridge which forms a spur of Copper Mountain (Pl. IX). The principal developments are along the crest of the ridge at an altitude of over 3,000 feet, where the discoveries of copper were first made. Prospecting on Copper Mountain began in 1897 and investigations followed the discoveries until early in 1900, when the properties were purchased by the Alaska Copper Company.

Developments were rapidly made by this company and included the construction of buildings and a large wharf. In 1902 several shipments of ore were made to the Tacoma smelter, about 500 tons in all, and they are reported to have yielded nearly $\$ 18,000$. In 1903 and 1904 there was no production, and developments were 

U. S. GEOLOGICAL SURVEY

BULLETIN NO. 347 PL. IX

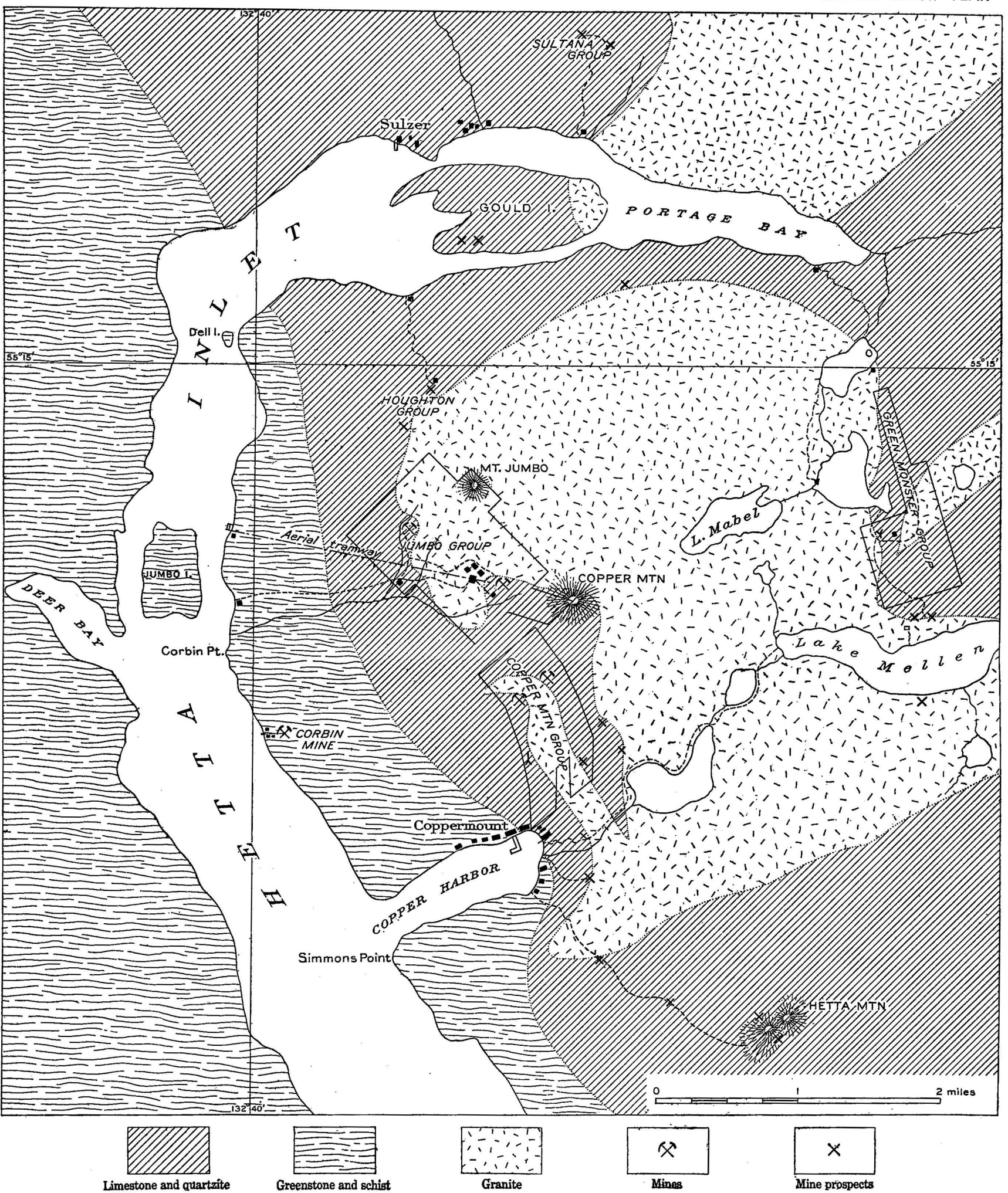

GEOLOGIC MAP OF VICINITY OF HETTA INLET, WEST COAST OF PRINCE OF WALES ISLAND.

Showing positions of mines and prospects. 

confined to the erection of a smelting plant and a power plant and the extension of a crosscut tunnel to undercut the ore body 1,000 feet below its outcrop. In October, 1905, these improvements were completed and smelting of the ore was begun.

Mine development.-The principal exploitations have been made by means of open pits or "glory holes" on New York and Indiana claims at altitudes of 3,300 and 3,500 feet, respectively. At 150 feet and 300 feet below surface outcrops two tunnel levels have been driven for undercutting. The upper level consists of 200 feet of tunneling and the second level 700 feet of tunneling with upraises to the surface. A long tunnel, including 3,000 feet of underground workings, enters the mountain at an elevation of 2,350 feet and undercuts the ore bodies at a depth of 1,000 feet. This lowest tunnel follows the contact zone of the granodiorite, first with quartzite and then with limestone. Its general course is northeasterly to a point 1,400 feet from its mouth, where it branches, the left or northwesterly branch continuing for several hundred feet along the contact to a point almost directly under the surface outcrop on the New York claim, while the northeasterly branch penetrates the massive granite belt for 700 feet toward the Indiana lode, which lies along the eastern contact.

The total mine developments at the close of 1906 are roughly estimated at 4,200 feet of tunneling and 500 feet of shaft sinking and raises, besides much open-pit work. The ore was chiefly mined from the upper workings on the New York claim and delivered to the smeiter over a cable tram 6,000 feet in length.

Smelter.-The smelting plant is close to tide water at the head of Copper Harbor and consists of a 250-ton Allis-Chalmers blast furnace, ore bins of 2,500-ton capacity, coke bins of 1,200-ton capacity, and a sample mill, besides the usual appliances for the granulation and removal of the slag ( $\mathrm{Pl} . \mathrm{X}, A)$. The ore from the Copper Mountain mine is delivered to the sample-mill bin by an aerial tramway 6,000 feet long, while the ore shipped to the smelter is unloaded into receiving bunkers of 1,000-ton capacity on the wharf, and from these is drawn off into cars and hoisted on an inclined tramway to the sample mill.

In addition to the smelting plant there is a sawmill, blacksmith and machine shop, store and warehouse, assay office, and compressor plant. All of the necessary machinery at both of the mines and at the smelter is run by water power derived from Reynolds Creek. The water is transmitted 1,000 feet by a 22 -inch pipe line to the compressor plant, where two water wheels develop 300 horsepower. The smelter was first operated for an experimental run in June, 1905, and since then has been operated at irregular intervals. In the summer of 1906 a large tonnage of ore was smelted with a considerable produc40840-Bull. 347-08-7 
tion of matte. In October, 1906, the smelter was closed pending a reorganization of the company and no attempt was made to operate it during 1907.

Ore bodies.-Two principal ore bodies, the New York and Indiana lodes, are worked on the Copper Mountain group of claims. The outcrops are on the crest of the mountain ridge at elevations of 3,300 and 3,500 feet, respectively. Both are contact metamorphic deposits similar in mode of occurrence and origin and separated from each other by a belt of granodiorite 800 feet wide.

The ore body exposed on the New York claim occurs at the contact of the granodiorite with limestone, along which it has been exposed by a long tunnel and by surface cuts for 2,000 feet. In the tunnel the width of the deposit varies from 10 to 50 feet, and the ore is confined to the garnet-epidote contact rock. - At the surface workings, however, the copper ores have been spread out into the somewhat fractured limestone hanging wall (Pl. $\mathrm{X}, B)$. This spreading is attributed to the action of meteoric waters, which has also altered the original sulphide ore into an oxide and carbonate ore, occurring in the form of pockets, small pipes, and gashes in the garnet gangue rock and in the limestone hanging wall. This action, however, has not taken place everywhere, and the unaltered sulphide minerals in the garnet-epidote gangue rock are not uncommon at the surface. Such alteration is absent at the tunnel level about 1,000 feet below the surface pit, and will probably rapidly decrease and become wanting within a few hundred feet of the surface.

The Indiana lode lies about 800 feet northeast of the New York lode and is parallel to the eastern contact of the outlying granodiorite belt indicated on the map ( $\mathrm{Pl}$. IX). The garnet-epidote-calcite rock and the inclosing rock extends across a width of nearly 500 feet. They are cut by a network of quartz stringers and include masses of crystalline limestone. The ore occurs irregularly and is not confined to the contact.

The present workings are on irregular ore masses near the contact, but the limits and extent of these are but little known. In origin and character of mineralization this lode is similar to the New York lode, but the values contained are lower and more scattered. The ore is composed of both carbonate and sulphide minerals of copper and contains from $\$ 1$ to $\$ 2$ in gold and silver values. Tunnels have been driven at points 40 to 220 feet below the floor of the surface pit in order to investigate this deposit in depth. The extemsion of the main tunnel at the 2,300-foot level will undercut this ore body 1,150 feet below its surface exposure. The ore from this mine is transported by a surface tram 1,400 feet in length around the south side of Copper Mountain to the head of the aerial tram at the New York claim. 


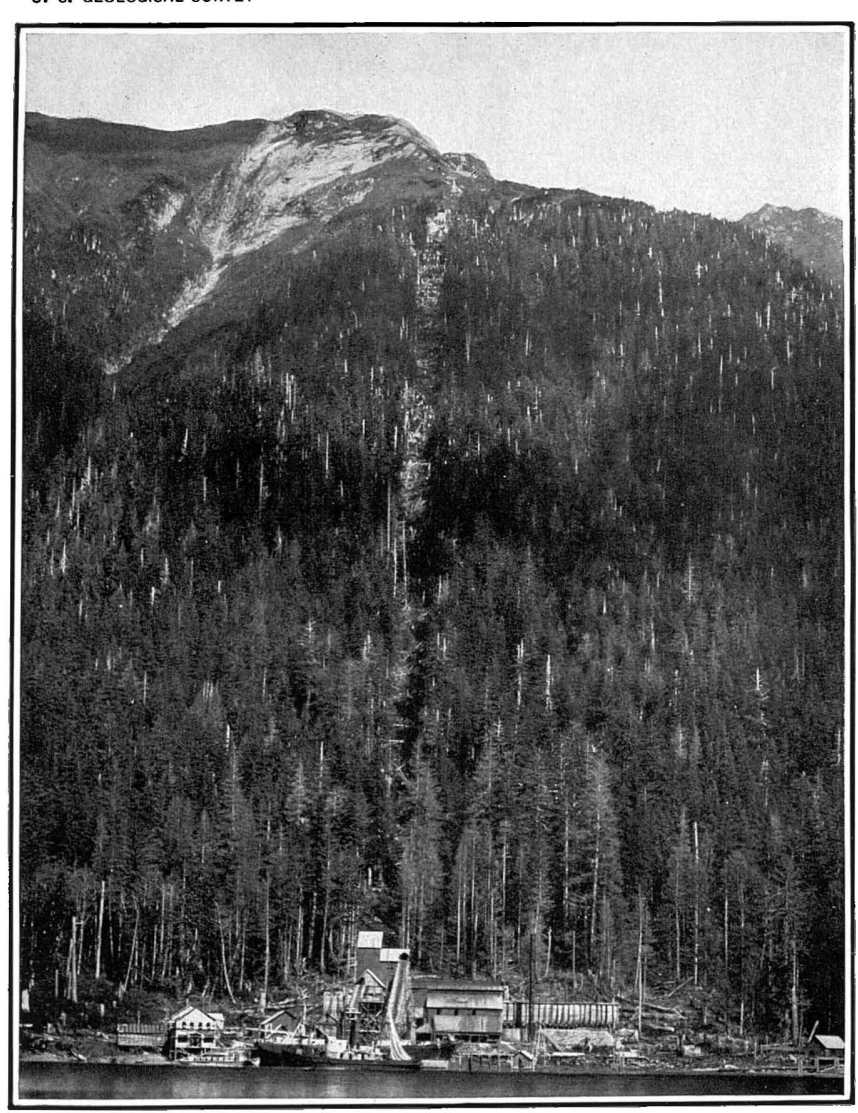

A. SMELTER, TRAMWAY, AND MINE WORKINGS ON COPPER MOUNTAIN, LOOKING NORTH FROM COPPER HARBOR.

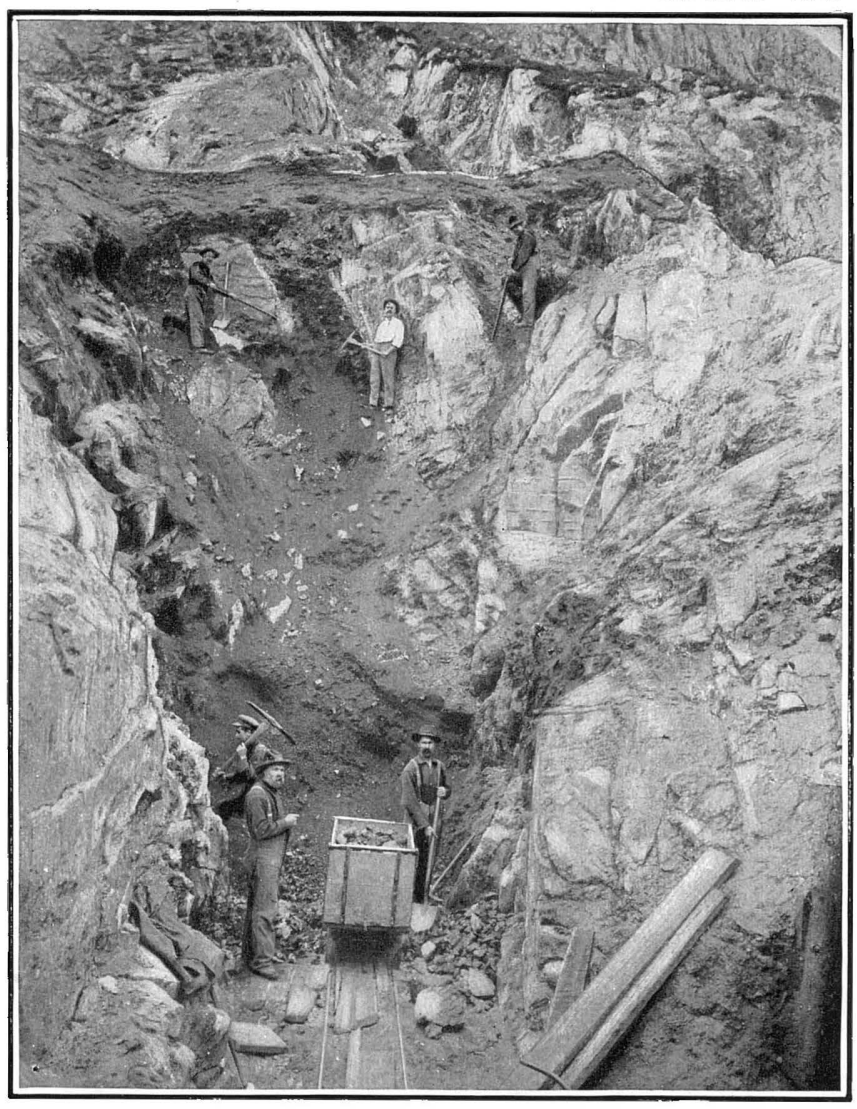

B. SURFACE WORKINGS ON CREST OF COPPER MOUNTAIN. 

JUMBO GROUP.

Situation.-The claims of the Jumbo group belonging to the Alaska Industrial Company occupy the slopes of Jumbo basin on the northwest side of Copper Mountain. The claims extend from a point 500 feet in elevation and 1 mile from tide water to near the mountain summit, 3,850 feet in elevation. Two main deposits are being explored, one between 1,500 and 1,900 feet on the east slope of Jumbo basin on the Jumbo claims Nos. 1, 1A, and 2, and the other between 1,600 and 2,000 feet elevation on the Jumbo claims Nos. 4 and 14.

Development.-Investigation of the Jumbo group began in 1902, and during the succeeding years various prospect tunnels were driven and test pits sunk on the different claims. After a promising ore body was opened on the claims Nos. 4 and 14, located at 1,700 feet elevation and 8,500 feet from tide water, it was next necessary to devise a means of transporting the ore to tide water. For this purpose a Riblett aerial tram 8,250 feet long and an additional aerial tram 600 feet long were erected in 1905-6, thus connecting the beach with the lower tunnel of the mine workings, 1,700 feet above sea. At the beach a wharf with 150 feet of frontage was built and ore bins of 4,000 tons capacity erected. While this was being done developments of the ore deposits were advanced, and early in 1907 shipments of the ore to the Tyee smelter.in British Columbia began.

Ore deposits.-The general rock relations of this area, which are similar to those shown at the Copper Mountain group previously described; are presented on the geologic map of Hetta Inlet (PI. XI). The main granodiorite boss forms the foot wall of the deposit, the hanging wall being in some places a crystalline limestone and at others an altered quartzite of a banded structure, varying from a white to a reddish or greenish color.

The copper deposit being mined is on Jumbo claim No. 4, and consists of an irregular body of chalcopyrite ore 30 to 40 feet wide, 120 feet long, and about 140 feet in depth, occupying a nearly vertical position. The contact zone in which this occurs is 200 feet in width at this point, granite forming the foot wall and limestone the hanging wall. The limestone beds are fractured and faulted, and masses of this rock are completely surrounded by the garnet-epidote contact rock. Mineralized masses of garnet-epidote, completely surrounded by the limestone, are also exposed, thus suggesting a replacement of the limestone by the ore-bearing minerals. On the foot-wall side there is no definite separation between the contact rock and the granodiorite, the mineral solutions having also replaced the mineral components of this rock, though less extensively.

The contact rock has a compact felsitic texture, and is locally called felsite, though it is composed mainly of garnet and epidote. 
Near the ore masses this rock becomes coarsely crystallized, the garnet and epidote form vugs of well-developed crystals, calcite occurs in small veinlets and masses, and chalcopyrite may be observed in scattered particles. Except such local changes there are no indications within the contact zone which may be used as a guide in the search for these ore masses. Those points where the limestone is in contact with the granodiorite appear to be most favorable for the occurrence of the ore deposits. Besides the minerals already mentioned scapolite, wollastonite, specularite, and molybdenite are present in small amounts.

The mine workings on Jumbo claim No. 4 consist of four tunnels between 1,550 and 1,950 feet in elevation and an open cut at 2,050 feet elevation. The main working tunnel, or tunnel No. 3, is situated at an elevation of 1,700 feet and is 280 feet in length. At a point 180 feet from its mouth a 130 -foot vertical raise connects this level with the stopes in the ore body and tunnel No. 2. At a point 40 feet above the tunnel a small stope has been extended to the west on what is supposed to be the bottom of the main ore body, and 30 feet above this a 60 -foot exploratory drift has been extended to the east into the ore. The floor of the main stope is 100 feet above the level of tunnel No. 3. The stope is 160 feet long, 20 to 40 feet in width, and extends for 30 feet above the level of tunnel No. 2. The ore mined goes through this raise, whence it is trammed to the upper terminal of the aerial tramway, and from there it is transported to the ore bunkers at the beach.

In Canyon Creek 200 feet to the southeast of tunnel No. 2 surface mining and exploratory tunnels are being extended on the supposed continuation of this ore body. Tunnel No. 1 at 1,950 feet elevation crosscuts the limestone for 50 feet and enters the contact rock for 15 feet, in which indications of ore are shown. Tunnel No. 4 has recently been started at a point 1,570 feet in elevation on a level with the upper terminal of the main aerial tramway. It is planned to extend this tunnel to undercut the present mine workings, with which it will be connected by a raise through which the ore will be conveyed, thus eliminating the necessity of the auxiliary tramway from tunnel No. 3.

The upper workings are on Jumbo claim No. 14 just above tunnel No. 1 at 2,050 feet elevation. These consist of an open cut and surface stripping across a width of 100 feet. The irregularity of the deposits and the sporadic occurrence of the ore is well shown here. At one point a face of massive sulphide ore 6 feet across is surrounded by the barren gangue rock; at other points sulphides were finely disseminated in the rock in sufficient amount to make a lowgrade ore.

The ore body on Jumbo claims Nos. 1, 1A, and 2 is characterized by lower values in copper than in the deposit on Jumbo claim No. 4., 


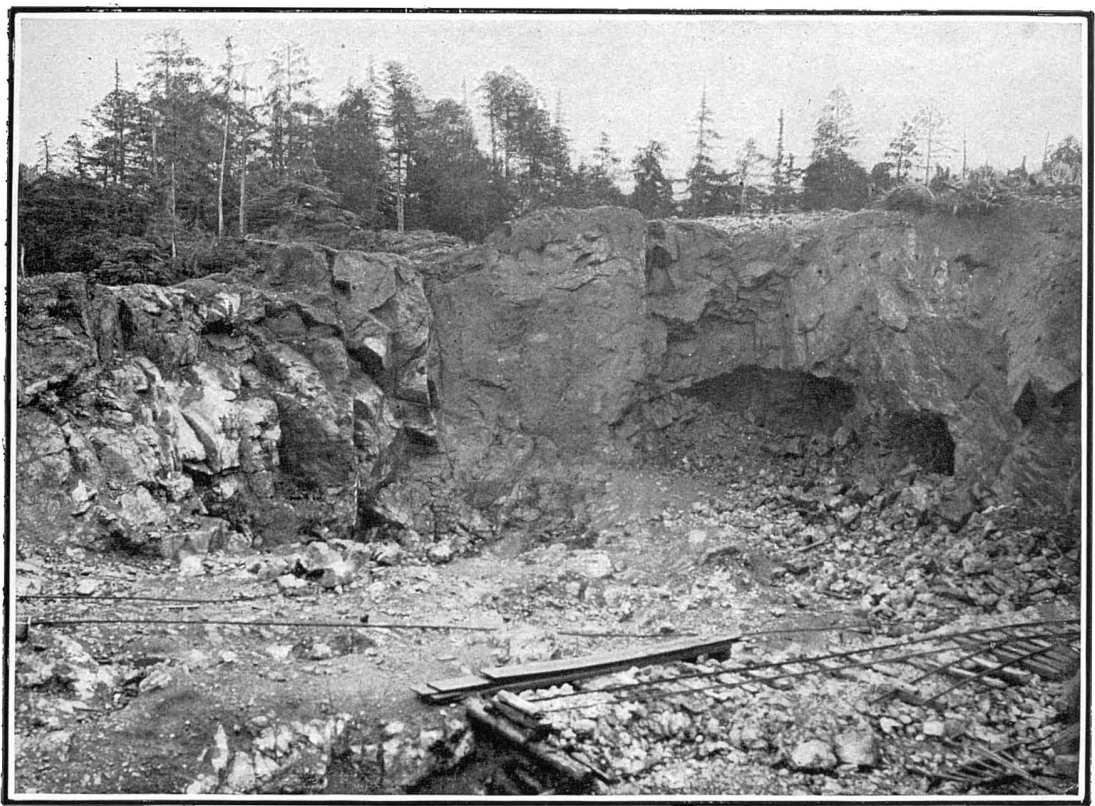

A. STEVENSTOWN MINE WORKINGS, SHOWING ORE BODY.

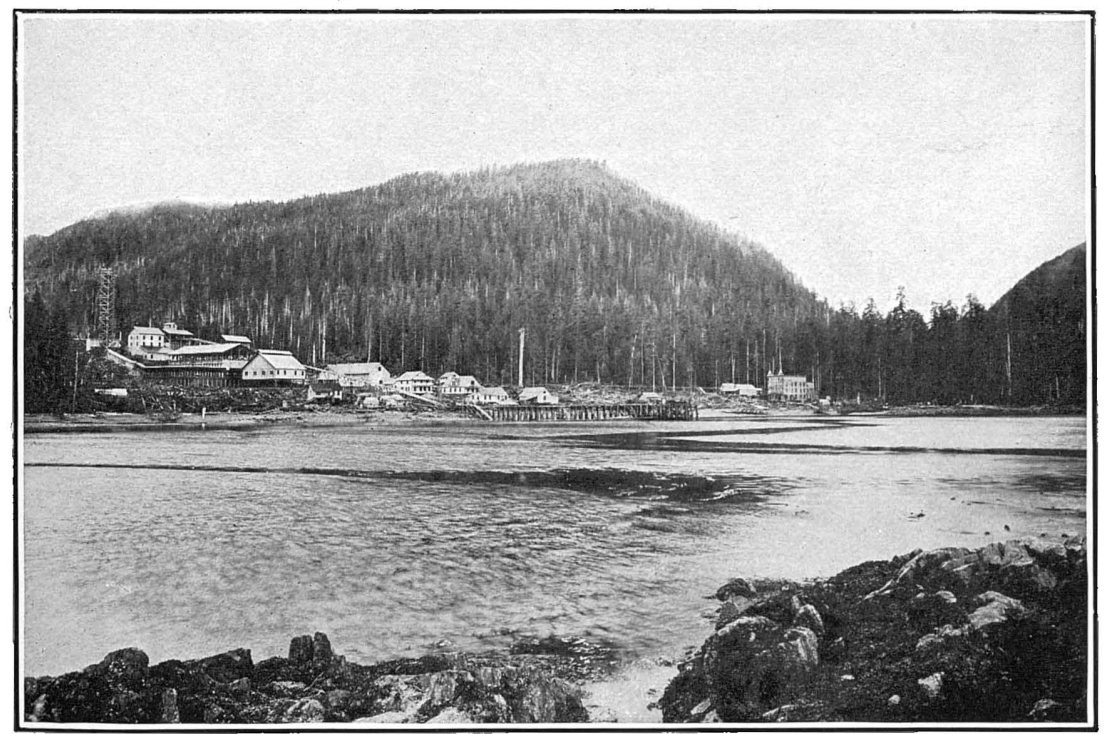

B. HADLEY, PRINCE OF WALES ISLAND, SHOWING SMELTER PLANT. 

and by a large percentage of magnetite, which mineral was conspicuously absent in the former deposit. Granite forms the footwall and both limestone and quartzite the hanging-wall side. Erosion has exposed the ore body over broad areas, so that it appears to form a relatively thin covering on the granodiorite, and becomes thinner as the elevation increases. The deposit outcrops in this manner between the 1,500 and 2,000 foot contours, but above 2,000 feet granodiorite alone was observed. This contact deposit between the hanging and foot walls generally varies from 10 to 60 feet in width, but in places it is altogether absent, and the granite and limestone are in direct contact with each other, as was observed at a point a few hundred yards northwest of the workings.

The highest openings are 1,890 feet in elevation on Jumbo claim No. 1, where a small open cut exposes considerable copper carbonate ore and limonite in a banded garnet-epidote gangue. This is only a surface alteration and disappeared at a depth of a few feet. Just south of this the deposit forms a steep bluff 100 feet high and exposed over a width of 100 feet. Masses of sulphide ore accompanied by magnetite were observed along the foot of this bluff where considerable surface stripping had been done. At 1,660 feet above sea a tunnel 85 feet long running N. $30^{\circ}$ E. crosscuts the limestone hanging wall for 20 feet, then penetrates a 10-foot band of epidote practically barren of ore, followed by 15 feet of crystalline limestone, and finally enters a belt of banded garnet-epidote rock for 50 feet without exposing the granodiorite foot wall. In the face of the tunnel small amounts of sulphide ore are scattered throughout the garnetepidote gangue, but as a whole the rock did not appear to carry sufficient copper to constitute an ore. About 100 yards east of this tunnel, at 1,580 feet elevation, on Jumbo claim No. 2, the ore body is again exposed over a considerable area and is richer in sulphide ore. Two tunnels crosscut the ore deposit, one 1;540 feet in elevation and the other 1,480 feet. The upper tunnel starts in the deposit, penetrates it for 50 feet, and enters the granodiorite foot wall for 6 feet. The line between the ore body and the foot wall was well defined, but there was no gangue present and the ore was closely welded to the granite. Near the face of the tunnel or foot wall the ore is of a fine texture, rich in epidote and magnetite, and carries but a small amount of sulphide, whereas at the entrance to the tunnel the gangue was made up of garnet containing small masses of chalcopyrite. The tunnel just below this crosscuts the limestone hanging wall for 55 feet and enters the ore body for 9 feet. The extension of this contact metamorphic deposit on Jumbo claim No. 1A has been exposed by two tunnels, one above the other, at 750 and 840 feet elevation. The upper tunnel penetrates a banded garnet foot wall, and about 25 feet from its entrance considerable sulphide ore was exposed. 
In the lower tunnel, which is 240 feet in length, the hanging wall exposed at the entrance is a reddish to dark-greenish indurated quartzite grading into the banded garnet-epidote rock near the tunnel face, where the granite foot wall is exposed. The contact metamorphic deposit at this point is nearly 100 feet wide, but the ore in it is scattered and as a whole is of lower grade than that exposed on the upper claims. The observations indicate that this deposit will be confined to the contact of the granodiorite foot wall and along this contact the occurrence of ore will be sporadic, the sulphide minerals occurring in masses or within limited contact areas connected with one another by the more or less barren garnet-epidote gangue rock. The average ore from this deposit contains a high percentage of iron and nearly sufficient silica for smelting purposes. Besides its copper content assays show values in gold and silver. The advisability of concentrating the ore by separating the magnetite from it and thus reducing its iron content is still to be determined.

GREEN MONSTER GROUP.

Situation.-The Green Monster group of claims, belonging to the Alaska Industrial Company, occupies the northern and western slopes of Green Monster Mountain, $2 \frac{1}{2}$ miles due east from Copper Mountain and 3 miles from the tide flats at the head of Hetta Inlet. From the latter point a trail, crossing two lakes each half a mile wide, at altitudes of 600 feet and 1,680 feet, respectively, leads to the principal mine workings at an elevation of 2,800 feet. Another approach to these claims is from Copper Harbor across a series of three lakes (indicated on the map, Pl. IX).

Development.-Although these claims were located in 1900, developments have been meager, and no attempt has been made to advance the investigation beyond the required assessment work. Two tunnels have been driven, one on Green Monster claim No. 1, 65 feet in length, the other on Diamond B. claim, also 65 feet long. On Iola claim a pit 8 feet deep has been sunk and trenches dug along the ore body.

Ore bodies.-Ore bodies at the contact of the limestone and granite are shown on the Iola, Black Warrior, and Diamond B. claims (Pl. XI). The deposit on the Iola claim has been opened by a small pit and surface stripping, and consists of a mass of magnetite-chalcopyrite ore 10 feet in width inclosed in the garnet-epidote gangue, which at this point occupies a width of about 25 feet between the limestone hanging wall and the granodiorite foot wall. Along this contact other smaller ore masses were observed on the Iola and Black Warrior No. 2 claims, but were apparently of little consequence. On the Black Warrior claims Nos. 1 and 5 similar ore bodies occur ad- 
jacent to the granite and limestone contact and in a black slate band along the mountain crest striking N. $30^{\circ}$ W., but these have not been prospected. On the Diamond B. claim a tunnel 65 feet in length has been driven along the contact of the limestone with a porphyritic dike striking $\mathrm{N} .30^{\circ}$ E. and 50 feet or more in width. The main contact of the granodiorite boss lies about 150 feet to the west. In this tunnel the garnet-epidote vein rock is exposed across a width of about 10 feet and for a length of 50 feet; the face of the tunnel enters the limestone. Small masces of copper sulphide occur in this contact rock, but the metal content of the vein as a whole is low.

A deposit in the form of a vein filling, occupying an irregular fissure in the limestone, occurs on Green Monster claim No. 1. This vein appears to be an offshoot from the main contact zone just west of it. A tunnel 65 feet long undercuts the vein, and for 250 feet along the surface it is exposed by trenches. The vein strikes S. $20^{\circ}$ E. with vertical dip and averages 6 feet in width. The copper occurs in small masses and disseminated particles throughout the garnetepidote-calcite gangue. Associated with the chalcopyrite ore is pyrite, and in places along the surface limonite, malachite, and azurite are present.

A third type of mineralization is exposed on Black Warrior claim No. 2, where a narrow vein 'containing galena, pyrite, and chalcopyrite has been deposited along the contact of a porphyry dike with the limestone country rock at a point about 1,000 feet from the granite contact. This ore, though of good quality, has not been found in quantity.

In general the ore bodies on the Green Monster group are similar in character to those on the Jumbo group, but from present excavations they do not appear to be as great as the latter in size and extent. The position of the property necessitates the building of a tramway over a distance of 3 miles in order to ship the ore, and conditions of mining are less favorable than at many other points along the coast.

\section{HOUGHTON GROUP.}

Situation and development.-The Houghton group of claims is located on the northwest slope of Mount Jumbo between elevations 1,000 and 2,000 feet and is 1 mile from Hetta Inlet. (See Pl. XI.) They include the granodiorite contact zone exposed on the Jumbo group to the south, and the ore bodies under exploration are of the same general type. The claims, including a mill site at tide water, were located in 1901, and from that time to the end of 1905 the developments were meager, assessment work alone being done. Early in 1906 the properties were acquired by the Cuprite Copper Company, two more claims were located, and active developments were begun. These investigations were advanced during 1907 with encouraging 
results. The present mining camp is situated at 1,500 feet and the mine workings between 1,600 and 1,700 feet elevation. At 1,600 feet a tunnel, 100 feet long at the time of the visit, was being driven to explore the ore body in depth, its surface exposure being 100 feet above. At other points on these claims short exploratory tunnels and cuts have also been made.

Ore body.-The copper deposit on which investigations are being furthered is included in the garnet-epidote contact rock which occupies a zone from 25 to 75 feet in width between the granodiorite and limestone. This zone strikes N. $45^{\circ} \mathrm{E}$. and dips steeply to the northwest. The ore body is developed on the surface by a 30 -foot cut and a 15-foot pit, in which a body of massive chalcopyrite ore 5 feet wide is exposed. In the tunnel which enters this contact zone small amounts of copper ore are present, but the main ore body is not yet undercut. The chalcopyrite is associated with magnetite, pyrite, and some pyrrhotite. The observations in general on these claims showed a less amount of contact metamorphism and not so great a development of ore as was noted at the Jumbo group.

\section{SULTANA GROUP.}

Situation and development.-The Sultana group of six claims is located on the north side of Hetta Inlet about 1 mile east of Sulzer and extends from tide water to an elevation of 1,000 feet on the south slope of Beaver mountain (Pl. XI). The principal developments have been on the Sultana claim, though on the adjoining claims, the Index and Vulcan, prospecting has been advanced. The total workings, however, amount to little more than the amount of assessment required each year.

Ore bodies.-The ore bodies exposed are contact-metamorphic deposits underlain by a granitic intrusive, banded siliceous limestone forming the hanging wall. A gangue of garnet and epidote with considerable calcite has been deposited along the contact, in which sulphides of copper and iron are sparingly distributed in small masses and disseminated particles.

At a point on the Sultana claim 350 feet in elevation and one-third of a mile from the beach a tunnel 130 feet long was driven in the granodiorite foot wall with no result. Another tunnel 430 feet in elevation exposes at its entrance a mass of chalcopyrite ore 3 feet in width and then crosscuts the garnet-epidote gangue rock for 25 feet, showing practically no ore. On the Index claim, to the east of the Sultana claim, at 600 feet elevation, an open cut 60 feet long exposes small amounts of chalcopyrite, not sufficient to make a profitable ore, associated with magnetite and pyrrhotite in a banded garnetepidote rock. On the Vulcan claim, north of the Sultana claim, at 
an altitude of 520 feet is an open cut 60 feet wide. Here garnetepidote rock occurs with large included fragments of banded limestone containing pyrrhotite and chalcopyrite in masses a few feet wide. A relatively small amount of ore is developed on these properties, but future explorations may reveal new and larger bodies. The ore at this prospect was reported to carry cobalt in considerable amount, but a sample taken by the writer and submitted for analysis gave only a trace of cobalt and less than 0.2 per cent of nickel.

CORBIN MINE.

Situation and development.-The Corbin mine is close to tide water on the east side of Hetta Inlet, $1 \frac{1}{2}$ miles north of the entrance to Copper Harbor. This property of four claims was located in February, 1905, and the following summer ore shipments were made to the smelter at Coppermount. Early in 1906 the mine was sold to the Alaska Metals Mining Company, which began active development and equipped the property with an air compressor, a hoist, a steampower plant, and erected a small wharf and various buildings. The position of the ore body necessitated the sinking of a shaft 100 feet, and at this depth considerable crosscutting and drifting were extended to investigate the ore body at this level. Adjacent to the shaft a tunnel has been driven along the vein for 210 feet, but the results were not encouraging. Operations on this property were suspended during the winter of 1907 and have not since been renewed.

Ore bodies.-The ore body is a vein deposit of nearly massive sulphide ore inclosed in a narrow fissue parallel to the stratification of a greenstone-schist country rock. The vein is from 1 foot to 3 feet in width and has been exposed about 250 feet in length, striking N. $70^{\circ}$ W. and dipping $70^{\circ}$ SW. A tunnel 210 feet in length was driven along the vein to the southeast and in this the vein narrows to a thin gouge seam and widens again at several points, its continuation being indicated by the bleached appearance of the country rock. The foot wall of the vein is a dark-green schist and appears less altered than the hanging wall, which is a pale-green talcose schist. Grooves caused by slipping were observed on both the foot and the hanging wall. These grooves pitch $50^{\circ} \mathrm{NW}$., and this is the direction that the ore shoots are most likely to follow. In the vein itself occasional slickensides were observed, indicating movement along these lines since the deposition of the ore. Dikes of diabase from 2 to 4 feet in width, striking $\mathrm{N} .10^{\circ} \mathrm{E}$. and dipping $70^{\circ} \mathrm{NW}$., nearly at right angles to the prevailing rock structure, crosscut the vein deposit. The ore is principally pyrite containing chalcopyrite associated with some ouartz and calcite as gangue minerals. Besides the small per cent of copper in the ore, gold and silver amounting to about $\$ 3$ in 
value per ton are reported. At other points on these claims exploration may reveal vein deposits similar to the one described.

COPPER CITY MINE.

Situation and development.-The Copper City mine, also known as the Red Wing group, consisting of four claims, is situated close to tide water on the east side of Hetta Inlet, 7 miles south of Copper Harbor. This property, because of its position and the character of the deposit, has been a copper producer in a small way ever since operations first began in 1903, the ore being sacked and shipped to the Tacoma Smelter. The developments have been confined to the Red Wing claim, where the vein deposit has been opened by an inclined shaft 120 feet in depth. From this shaft two levels, 50 feet and 100 feet respectively in depth, have been extended. The 100foot is the working level and this has been extended along the vein for 200 feet to the north and for 50 feet to the south of the shaft. At a point on the level 75 feet north of the shaft a 60 -foot winze has been sunk and from this a drift 50 feet long has been extended. Most of the ore above the 100-foot level has been mined, and it is proposed to sink the shaft an additional 100 feet and open up a 200foot level.

Ore body. - The ore body, a vein deposit of nearly massive sulphide ore, is inclosed in a slate-greenstone country rock parallel to the bedding plane and corresponds in general character to the ore body at the Corbin mine already described. The country rock grades from a black slate or siliceous schist to an amphibole schist or altered greenstone, the general strike being N. $20^{\circ}$ E. and the dip $60^{\circ} \mathrm{NW}$. Crosscutting these schists and also the vein deposits are several diabase dikes 1 foot to 5 feet in width, striking in a N. $30^{\circ} \mathrm{W}$. direction. These dikes were intruded after the main ore deposition, but subsequent mineralization has deposited small amounts of mineral in veinlets entering them, and the ore bodies, where crosscut, usually continue along the same line of strike on opposite sides of these intrusives. The vein as exposed in the shaft varies from 6 inches to 4 feet in width, narrowing to a gouge seam at 100 feet in depth. At this level the vein appeared to be displaced for a short distance toward the foot-wall side, where it was again found, and on it the 60-foot winze was sunk, in which the vein was reported to have a considerable width. Smaller veins of similar character and parallel to the main vein have been exposed by surface cuts and trenches at other points on the property, but none of these have been developed.

The ore is composed essentially of chalcopyrite, pyrite, sphalerite, and rarely hematite (specularite), associated with quartz, calcite, and epidote as gangue minerals. Surface oxidation has altered. the chalcopyrite in places to limonite and cuprite, and along jointing cracks 
in the country rock malachite and small films of native copper were observed. Besides the copper content, the ore contains values in gold amounting to $\$ 3$ to $\$ 6$, and silver amounting to $\$ 1$ to $\$ 3$, besides from 6 to 9 per cent of zinc.

\section{PROSPECTS ON GOULD ISLAND.}

Gould Island, which occupies the head of Hetta Inlet, is about 2 miles in length and less than 1 mile wide. It is composed essentially of limestone, siliceous schists, and slate intruded by a granodiorite mass which occupies the eastern portion of the island (Pl. IX). The prospects are located at the southwest end of the island. The ore which consists of galena, spalerite, and chalcopyrite, occupies small veinlets, and is finely disseminated in a belt of siliceous limestone 30 feet wide, striking east and west,'with a steep dip to the north. Associated with the ore are calcite, quartz, garnet, epidote, and large amounts of wollastonite, the latter occurring in the adjacent limestone in radiating masses. A tunnel 70 feet long has been driven along the foot wall of this mineralized belt, where it is in contact with slate, and scattered occurrences of ore are shown. Just north of the tunnel is an open cut and a shaft 10 feet deep, exposing mineralized rock of the same character. About 300 feet east of these workings is another open cut and a pit 10 feet deep on the same belt. The amount of ore exposed on these claims at the time of the writer's examination was small and of low grade.

\section{PROSPECTS AT HEAD OF COPPER HARBOR.}

The prospects at the head of Copper Harbor indicated on the map, excepting the Paris vein, are all contact-metamorphic deposits and lie adjacent to the same granodiorite batholith exposed on the Copper Mountain and Jumbo groups (Pl. IX). On none of these claims have the developments exceeded the assessment requirements. On the Paris group of claims, located at 300 feet elevation, about a half mile from the beach, a tunnel 115 feet in length has been driven along a small quartz vein 1 foot wide striking northeasterly and containing low values in copper and gold. The country rock is a banded quartzite striking N. $40^{\circ} \mathrm{W}$. and dipping $40^{\circ}$ to $60^{\circ} \mathrm{SW}$. The Gould group, which lies north of Reynolds Creek and at 300 feet elevation, onehalf mile from Copper Harbor, is located along the granodiorite contact with quartzite which at this point strikes S. $20^{\circ}$ E. A tunnel 50 feet long crosses the contact rock and enters the granite, which also carries small amounts of chalcopyrite and pyrrhotite scattered near the contact in fine particles. A 40 -foot shaft at the mouth. of the tunnel exposes the mineralized garnet-epidote rock, showing a banded structure striking parallel with the contact and dipping $60^{\circ} \mathrm{SW}$. About a mile northeast of the Gould group and 
at 100 feet elevation is the Russian Bear claim, and adjoining this on the north the Texas claim at 1,450 feet elevation. The contactmetamorphic deposits on both these claims flank the western slope of the granodiorite batholith, and the developments consist mainly of open cuts and trenches, in which only small ore masses have been exposed.

PROSPECTS ON HETTA MOUNTAIN.

Hetta Mountain, which lies southeast of Copper Harbor, is made up essentially of limestone and quartzites, its northern slope, as indicated on the map (Pl. IX), being bordered by the granodiorite intrusive. Two claims have been located on contact deposits similar to those described along the intrusive contact about 1 mile from Copper Harbor and at 900 feet elevation. The ore bodies have been prospected by three tunnels, one 20 feet, one 25 feet, and one 30 feet in length, and several open cuts in which small masses of chalcopyrite and pyrrhotite are exposed in the garnet-epidote contact rock. The quartzitic schist country rock to the south, which forms the hanging wall or the deposits, strikes east and west with nearly vertical dip, and is intersected by granitic and pegmatitic dikes.

In a gulch at 1,380 feet elevation another prospect is located on a vein deposit consisting of garnet with some epidote and sulphide ores in the siliceous schists. At this point a tunnel 30 feet long has been driven along the vein and at the entrance a small mass of chalcopyrite ore is exposed. On the ridge of Hetta Mountain the quartzites alternate with limestone strata having a N. $80^{\circ}$ E. strike, and intruding these beds are occasional masses of granodiorite. Along the contact of one of these dikes at 2,480 feet elevation, on the north slope of the ridge, a contact-metamorphic deposit occurs which contains both the sulphide and the carbonate ore of copper. A tunnel 15 feet long and considerable stripping constitute the developments and expose small masses of the copper ore in a garnet gangue. Southeast of this prospect on the opposite side of the ridge, at 2,500 feet elevation, an iron capping has been explored by trenches, and in these also small amounts of copper ore are exposed.

\section{Kasaan peninsula.}

GENERAL DESCRIPTION.

Kasaan Peninsula is a promontory on the east side of Prince of Wales Island 18 miles in length and from 3 to 6 miles wide, projecting into Clarence Strait and sheltering Kasaan Bay (see fig. 1, and map, Pl. I, in pocket). It is a steep, heavily timbered mountain ridge with summits reaching altitudes of 1,000 to 3,000 feet. The range is dissected near the center of the peninsula by a low pass 400 
feet at its highest point, extending from the "Hole in the Wall" to a point 3 miles southeast of Kasaan village. At the northeastern end of the peninsula is also a broad, low marshy valley 4 miles in length, extending from the head of Tolstoi Bay to a point 3 miles northwest of Kasaan, and another low pass 3 miles long from the head of Thorne Bay to the east side of Karta Bay. The timber on the peninsula extends to an elevation of from 1,500 to 1,800 feet, below which

FIG. 1.-Map of Kasaan Peninsula, showing mine locations.

a dense undergrowth renders prospecting difficult. The summits of the ridges are open except for small clusters of scrubby pine.

The relief of the peninsula is typical of the more mature topography of the islands as compared with the rugged, more abrupt topography of the mainland. The mountain summits are dome shaped and on them are large erratic bowlders, an evidence of glaciation. 
The valleyś, which extend northward from near the head of Kasaan Bay, are broad and contain many lakes, and in them are deep deposits composed of large and small bowlders embedded in glacial clay. The islands and shoals at the entrance to Karta Bay are made up entirely of these glacial deposits and represent the end moraines left by former ice fields.

The occurrence of copper on Kasaan Peninsula was known to the Russians as early as 1865, but not until 1900 did active mine developments begin. It is now the principal copper-producing area in southeastern Alaska.

\section{GEOLOGY.}

Kasaan Peninsula is composed largely of underlying intrusive rocks, including granodiorite, syenite, hornblende diorite, and more rarely granite. These rocks invade limestone beds and strata of highly. altered sedimentary and pyroclastic rocks ranging from greenstone tuffs to sandstones and conglomerates composed principally of igneous material.

Stratified rocks.-The stratified rocks include those of sedimentary and volcanic origin. They occur principally on the northern portion of the peninsula and adjacent to Tolstoi and Thorne bays, and are made up of a series of metamorphosed bedded rocks altered to hornfels and mica schists and often highly epidotized and containing amphibole and pyroxene crystals. These range in texture from finegrained tuffs, slates, and sandstones to coarse conglomerates. The conglomerates contain many fragments and pebbles of igneous rocks as well as of limestone and quartzite. The sandstones and greenstone tuffs are composed largely of volcanic material, and because of their induration they closely resemble massive igneous rocks. In most places their fragmentary character may be recognized. The limestone beds exposed on the peninsula are entirely recrystallized, and both evidence of structure and organic remains are lacking. They are of importance because of their association with and relation to the ore deposits. Limestone beds, conformably underlain by sandstones composed largely of igneous material, occur on Long Island, which occupies the central portion of Kasaan Bay and lies 1 mile southwest of Kasaan Peninsula. Interstratified in these limestone beds near their contact with the underlying rocks are thin beds of sandstone and conglomerate, most of the pebbles in the latter being of porphyry. In the limestone beds themselves Devonian fossils are abundant; collections in this locality were first made in 1901 by Brooks, and in 1905 a more complete collection was made by E. M. Kindle. Because of the analogy of these rocks to those on Kasaan Peninsula, the latter are provisionally considered to be Devonian.

The structure of the sedimentaries exposed on Long Island is of interest because of the two systems of folding represented, an 
older system of small folds with a northeasterly strike and a later system of broader folds which trend to the northwest and belong to the main system of the Coast Range. On the peninsula the structure of the bedded rocks has been so greatly interrupted by the intrusive masses that no persistent lines of strike and dip could be followed, though the most prominent direction of the bedding planes was from northwest to west with a steep dip to the southwest. Two prominent jointing systems are also present on the peninsula, the one striking $\mathrm{N}$. $15^{\circ}$ to $25^{\circ} \mathrm{E}$. with a dip $60^{\circ}$ to $80^{\circ} \mathrm{SW}$. and the other striking N. $50^{\circ}$ to $70^{\circ} \mathrm{W}$. with a steep dip to the northwest. .

Intrusive rocks.-The intrusive rocks occurring on Kasaan Peninsula all invade the sedimentary strata and are therefore of more recent age. The principal intrusive, however, is the granodiorite which forms the entire southern portion of the peninsula and occupies wide areas in the central and northwestern portions. But little is known of the rocks that were intruded into this area previous to the granodiorite, this being the oldest intrusive rock recognized. The granodiorite intrusives, however, vary considerably in composition and probably represent several periods of igneous invasion during one general epoch, though in some instances this difference can undoubtedly be attributed to segregations within the igneous magma during solidification. After the intrusion of the granodiorite, granite and syenite dikes or masses many hundred feet in width were intruded, besides numerous pegmatite and aplite dikes. Somewhat later or possibly during the same period rocks more basic intruded the area in the form of dikes. These were followed by felsitic dikes from one to several hundred feet in width. Still more recent are the diabase and basaltic dikes, all of which are later than the ore bodies.

ORE DEPOSITS.

The occurrence of ore on Kasaan Peninsula is similar to that in the vicinity of Hetta Inlet. The ore bodies are contact-metamorphic deposits occurring usually at the contact of an intrusive syenite mass with limestone and in some places with greenstone tuff or conglomerate. They are included in a garnet-epidote gangue and are generally associated with magnetite, this mineral forming in many places half of the gangue. The principal mineral zone defined on this peninsula follows the contact of a syenite intrusive mass with a narrow belt of limestone, and is traceable from the east side of Mamie Creek for 2 miles in a westerly direction. This zone ranges from 100 to 300 feet in width, though because of its flat dip and its conformity with the contour of the mountain slope it appears locally to be much wider. The Mamie, Stevenstown, and Mount Andrew mines are included within this zone. Another smaller belt of contact deposits 
appears to follow along the western side of the peninsula about 1 mile inland, beginning 3 miles northwest of Kasaan and continuing northwestward to Karta Bay. The Sea Island, Haida, and Coppercenter prospects are included in this belt. Besides the contact-metamorphic deposits, copper ores associated with quartz are found occupying sheer zones in the greenstone tuffs and conglomerates at the head of Karta Bay, namely, in the Rush \& Brown mine and at the Venus prospect. On the east side of Karta Bay bornite and chalcopyrite occur in small masses and are disseminated throughout a basic diorite intrusive belt on the Goodro and Stevens prospects. Vein deposits containing essentially silver-lead ores occur in the limestones northeast of Kasaan.

The persistency of these various ore bodies depends largely upon the type. The contact deposits are generally irregular masses of small extent as a rule and no more persistent in depth than they are laterally; but where the contact zone is extensive, investigations within it will probably reveal similar ore masses both laterally and in depth. The copper-iron sulphide deposits in shear zones in the stratified rocks are more persistent than the contact ore bodies and will probably extend to a considerable depth. The vein deposits in the limestones will also be extensive in depth, but will vary considerably in width, often narrowing to a mere seam.

To judge from analogous deposits of the latter type, it is possible that the lead-silver ores will be replaced by copper ores in depth.

MAMIE MINE.

Situation and development.-The Mamie mine, owned by the Brown Alaska Company, is situated $1 \frac{1}{4}$ miles south of Hadley, at an elevation of 700 feet, in the central portion of Kasaan Peninsula (figs. 1 and 2). The mine workings are connected with the smelter at Hadley by an aerial tram 5,500 feet in length and with the beach by a horse tram 7,700 feet in length. The horse tram is used for the transportation of supplies. Mine developments in a large way were not begun until 1904. During that year the ore bodies were explored by numerous open cuts, tunnels, and diamond-drill holes. In the following year mining of the ore was begun from the open pits and new ore bodies were developed by tunnels and shafts. At the close of 1905 considerable ore was delivered to the smelter, and throughout 1906 the production was large. In 1907 diamond-drill investigations were advanced, new ore bodies were located at greater depth, and the ore production continued with little interruption until late in September. In October all operations were suspended. The total developments consist of 5,000 feet of tunneling, drifting, and crosscutting and about the same amount of diamond-drill prospecting. 
The smelter or reduction plant at Hadley, belonging to the Alaska Smelting and Refining Company, is controlled largely by the owners of the Mamie mine (Pl. XI, $B$ ). It consists of a blast furnace of

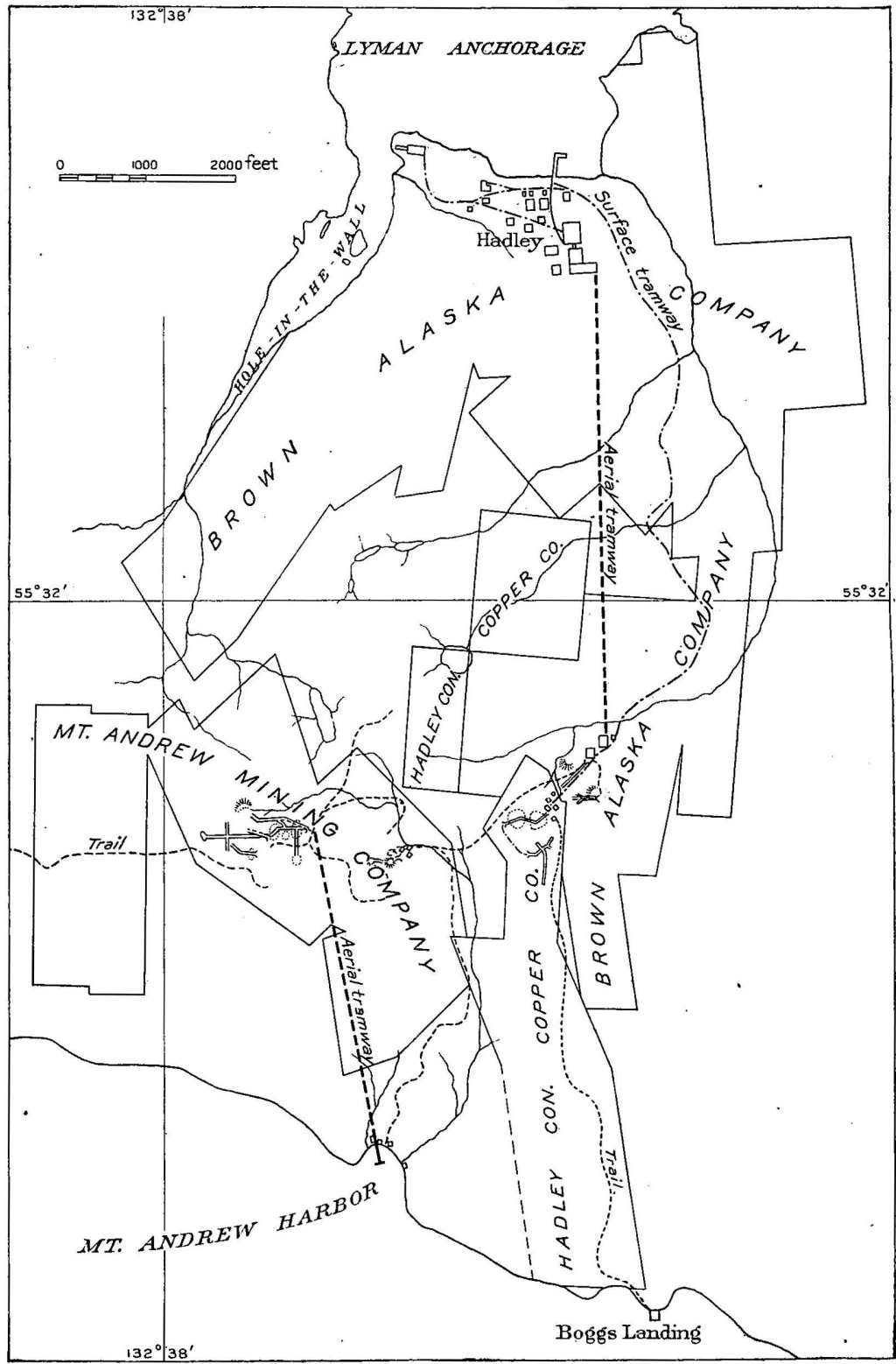

Frg. 2.-Map showing properties of the Brown Alaska Company, Hadiey Consolidated Company, and the Mount Andrew Mining Company.

350 tons daily capacity, a sampling mill, coal and coke bins, ore bunkers of 10,000 tons capacity, boiler house, engine house, electric40840-Bull. $347-08-\mathrm{S}$ 
light plant, and other conveniences. The ores from the Mamie and Stevenstown mines first go through the samplers, next to the ore bunkers by gravity, and thence by gravity to the furnace. The slag from the furnace is granulated and carried by water to the beach. A cable tramway extends from the wharf to bins above the sampling mill, which have been built to receive custom ore. The plant is so arranged that its daily capacity may be doubled if necessary. Smelting operations began December 5, 1905, and in 1906 the furnace was in blast about twenty days each month. In September, 1907, this plant was closed.

Ore bodies.--The ore bodies at the Mamie mine are contact metamorphic deposits included in a zone 400 feet wide lying between a syenitic intrusive and limestone. Within this zone the masses of valuable copper ore are defined either by such a decrease in the copper content of the inclosing rock as to prohibit profitable extraction or by fault planes. Garnet, epidote, and magnetite compose the contact rock. Chalcopyrite is present throughout in small quantities. The ore bodies or portions of the contact rock where the concentration of the copper values is sufficient to make ore are irregular masses ranging from 50 to 100 feet in length and thickness and from 10 to 40 feet in width, the major axis striking northward. Nine such ore masses are exposed in the mine workings. Some of them are included entirely in magnetite masses, thus making basic ore, while others occur in the garnet-epidote gangue rock, making a siliceous ore. Small veinlets of calcite and rarely quartz intersect the ore masses, thus indicating a later period of mineral deposition, though the main ore deposits are believed to have been deposited contemporaneously with the inclosing contact rock.

STEVENSTOWN MINE.

Situation and development.-The Stevenstown mine, owned by the Hadley Consolidated Copper Company, is situated just above and southwest of the Mamie mine at an elevation of 1,000 feet (fig. 2). From the mine a surface tram 700 feet long connects with the aerial tram at the Mamie mine, over which the ore is transported to the smelter at Hadley. A trail also leads from the mine down the south side of the peninsula to Boggs Landing, on Kasaan Bay, a distance of 1 mile. The mine has been developed by three "glory holes" or open pits connected by raises with a 550 -foot tunnel penetrating the crest of the mountain. Actual mining developments were first begun in June, 1905, previous to which time prospecting alone had been carried on, and in September of that year ore shipments to the Hadley smelter began. A large amount of ore was produced during 1906, and until the first of July, 1907, when mining operations were suspended. 
Ore bodies.-The ore bodies on the Stevenstown property correspond both mineralogically and genetically with those at the Mamie mine $(\mathrm{Pl}$. $\mathrm{XI}, A)$. They occupy a relatively flat position on the crest of the mountain ridge and are apparently underlain by the syenite intrusive which forms the foot wall of the mineral belt and which is exposed throughout the tunnel that penetrates the mountain top. The hanging wall as well as a large portion of the ore bodies on this property have been removed by erosion and the contact zone is only from 20 to 40 feet in width instead of 200 to 400 feet, the width on the Mamie property just below. To the northeast of the ore bodies strata of limestone and greenstone tuff occur and continue westward toward the Mount Andrew mine, forming the hanging wall of the mineral zone.

The mine workings are all surface pits connected by raises with the main tunnel, and in these several relatively flat-lying ore masses have been developed. These masses are included within an area 350 by 200 feet, the pits being from 20 to 40 feet deep. The central portion of this area is traversed in a southerly direction by a 40 -foot felsite dike, which is of later intrusion than the syenite and crosscuts the ore body. Smaller dikes of diabase and basalt 1 foot to 5 feet in width were observed crosscutting the ore bodies and country rock at several points in these mine workings.

The ore is composed largely of magnetite, chalcopyrite, and pyrite associated with hornblende and calcite, all of which are included in a more or less banded garnet-epidote gangue.

Surface oxidation has produced considerable limonite and some malachite and azurite; small particles of native copper also occur along slipping planes, though these secondary minerals are relatively unimportant.

MOUNT ANDREW MIINE.

Situation and development.-The Mount Andrew mine workings are situated three-fourths of a mile from Mount Andrew landing on the southwest side of Kasaan Peninsula and one-half mile west of the Stevenstown mine, at an elevation of 1,400 feet. A cable tramway 3,600 feet long leads from the mine over a 1,440-foot knoll just south of the workings to the ore bunkers and a wharf at Mount Andrew landing (fig. 2).

This mine is developed principally by a tunnel 620 feet long, undercutting the ore bodies from 60 to 100 feet or more in depth. From this tunnel several hundred feet of drifting and crosscutting have bèen driven, and upraises extended through the ore bodies to the surface. The ore is mined out of large underground stopes and from surface pits or glory holes, and is delivered through chutes at tunnel level to the ore bunkers at the head of the aerial tram and thence 
carried to the wharf, where it is loaded for shipment. Developments in a large way were not begun until late in 1905, and during 1906 the aerial tram was erected, the wharf built, the compressor plant installed, and considerable ore developed. The first ore shipments were made in October, 1906, and production continued until October, 1907 , when operations were suspended.

Ore bodies.-The ore deposits on this property are included in the same mineral belt as those at the adjacent Mamie and Stevenstown mines, with which they are in every way comparable. Six ore bodies

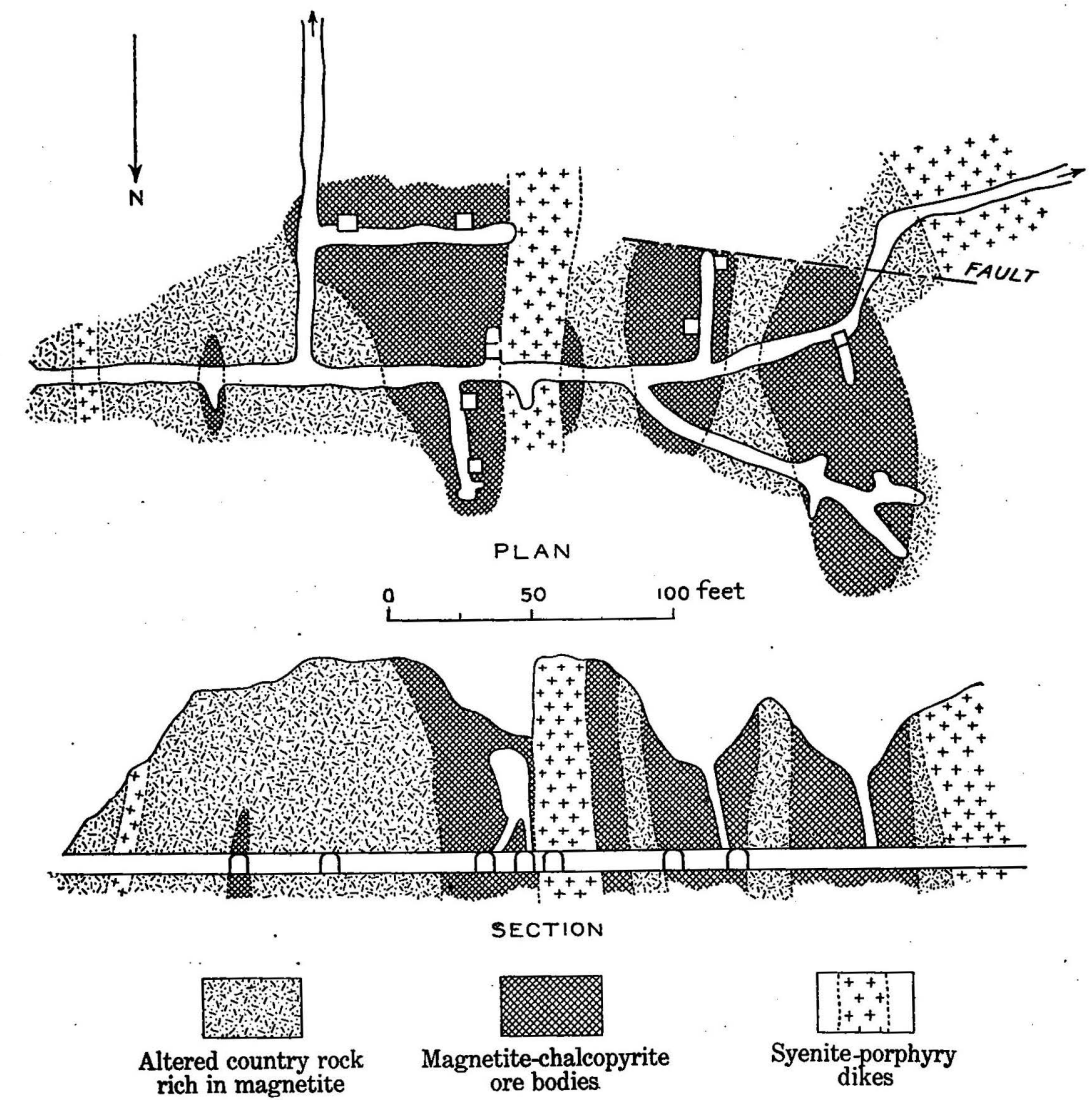

Frg. 3.-Plan and cross section of Mount Andrew mine workings, showing positions of ore bodies.

consisting of irregular magnetite-chalcopyrite masses associated with the garnet-epidote contact rock have been developed and mined to a considerable extent. These bodies of ore are from 10 to 50 feet wide, 40 to 80 feet long, 100 feet or more in depth, and have a general northerly strike and pitch. They are separated by barren areas of contact rock and dikes 20 to 60 feet of altered syenite porphyry (fig. 3). The mine workings consist essentially of surface pits which are undercut by a crosscut tunnel running east and west. This tunnel 
with connecting drifts and raises includes 2,200 feet of underground developments. Numerous gouge seams and slickensides indicating faulting were observed in the mine workings, and lateral displacements of the ore bodies from 1 to 6 feet were noted. Dikes of diabase and felsite from 2 to 12 feet wide crosscut the ore bodies and country rock in various directions and were evidently intruded later than the formation of the ore deposits.

At other points on Mount Andrew large masses of the magnetite carrying but a small percentage of copper, insufficient in amount to inake a copper ore, have been developed. These deposits, though not valuable for copper alone, may at some future time be of importarce as a source of iron ore.

UNCLE SAM MINE.

Situation and development.-The Uncle Sam mine, originally called the White Eagle group, lies 3 miles northwest of Mount Andrew landing and one-half mile from Kasaan on the south slope of Kasaan Peninsula (see fig. 1). The mine workings are 430 to 550 feet in elevation and less than half a mile from the beach. Mining operations have been advanced on this property at various intervals since its discovery in 1899, and in 1901 an aerial tram, ore bunkers, and a wharf were built. Early in 1906 a shipment of ore was made, but no further work was done until March, 1907. At that time operations were renewed, continuing until July, when another ore shipment was made. The mine is developed by a tunnel and drifts, amounting to about 800 feet in length, and by open pits exposing the ore body on the surface above the tunnel. From this working tunnel a surface tram, 1,150 feet long, conveys the ore to the wharf.

Ore body.-The ore body exposed in the tunnel consists of an irregular lens of chalcopyrite-pyrite ore 6 to 8 feet in width, striking north and south and pitching about $45^{\circ} \mathrm{N}$. It is cut off to the north by an east-west fault dipping $80^{\circ} \mathrm{N}$., which shows but a small amount of gouge. At the open cut above the tunnel similar masses of ore are exposed, but no large ore bodies have been defined. Garnet, epidote, magnetite, and calcite occur as gangue minerals and in many places form small geodes. The chalcopyrite ore contained in this gangue rock is irregularly distributed in small masses and not along definite lines. The country rock is made up of strata of chloritized and epi-dotized greenstone tuff which are underlain by the intrusive syenite and are crosscut by small dikes of diabase, of later origin than the ore bodies.

COPPER QUEEN GROUP.

The Copper Queen group of claims, which represent the first copper locations on Prince of Wales Island, lies about one-half mile southeast of Kasaan. In 1898 these claims were sold to the Kasaan 
Bay Mining Company, which made additional locations. Small operations were in progress from 1899 until 1902, and 500 feet of tunneling was done besides surface excavations. Since 1903 the property has been idle.

The principal ore deposit is exposed along the side of a gulch at a point 300 feet in elevation. It consists of an irregular mass of chalcopyrite ore accompanied by pyrite and magnetite in a garnet-epidote gangue, at the contact of an altered intrusive syenite with the greenstone tuff. Below these exposures a crosscut tunnel 400 feet in length has been driven in the altered syenite, but has failed to reveal any ore.

Other mineral exposures occur on these claims at points close to tide water and have been prospected by shafts and open cuts, but so far no important deposits have been discovered.

POOR MAN'S GROUP.

The Poor Man's group of two claims is located 2 miles northwest of Kasaan (fig. 1). The mine workings are connected with deep water by a surface tramway and wharf, having a total length of about 2,000 feet. The principal developments are at the head of the tramway and consist of a tunnel driven 90 feet in a southwesterly direction, which crosscuts a 40 -foot body of magnetite ore and 30 feet of garnet-epidote contact rock, and at its face enters a wide dike of red syenite for 20 feet. At a point 80 feet from the mouth of the tunnel is a vertical shaft extending 30 feet to the surface and 60 feet in depth. This body of magnetite is exposed on the surface above the tunnel, and similar masses have been prospected by short tunnels and cuts and shafts at points along the tramway and on adjoining properties. Associated with the magnetite are large amounts of calcite and hornblende, some pyrite and chalcopyrite, and garnet and epidote. Although the magnetite deposit itself is extensive, the chalcopyrite ore occurs only in isolated pockets or narrow veinlets and is not disseminated throughout the magnetite in sufficient amounts to make a copper ore of the entire body. It is noteworthy, however, that these ore bodies may be of value for their iron content. Minor displacements, due to faulting on slipping planes, and dikes of diabase and felsite crosscutting the deposits were noted.

EAGLE'S NEST GROUP.

The Eagle's Nest group of claims, situated 4 miles northwest of Kasaan, was first located in 1906, and in the same year was bonded to the Sea Island Copper Mining Company. Operations by this company were begun in October, 1906, and continued in a small way until September, 1907, when the property. reverted to the owners. 
The developments have been confined to the mineral exposures on the Alarm claim at an elevation of 400 to 500 feet. On the southeast end of this claim is a 70-foot tunnel essentially in a garnetepidote rock in which a small amount of ore occurs near the face. Just above the tunnel a body of magnetite-chalcopyrite ore 8 feet wide and 20 feet long is exposed in an open cut, beneath which are beds of limestone. Above this near the summit of the ridge is an open cut and shaft 12 feet deep exposing small amounts of ore associated with garnet in limestone. On the northwest end of this claim an open cut and a shaft 35 feet deep expose masses of chalcopyrite associated with various contact minerals in a coarsely crystalline limestone. Above the latter workings diorite is exposed and forms the upper portion of the ridge. No large copper deposits have been developed on these claims, though further investigation may reveal important ore bodies.

TAYLOR PROSPECT.

The Taylor prospect, located early in 1907 as the It claim, adjoins the Eagles Nest group on the east. On this prospect, at a point 600 feet in elevation, a body of chalcopyrite ore in a gangue of garnet and epidote has been exposed by surface cuts over an area of 20 by 40 feet. The ridge to the southwest or the foot-wall side is composed of diorite, and below the prospect to the northeast limestone beds are exposed.

MAMMOTH GROUP.

Situation and development.-The Mammoth group lies on the east side of Karta Bay, about 6 miles from Kasaan and one-third of a mile from tide water on the top of a low hill 500 feet in elevation (fig. 4). The property was largely developed in 1904-5 by. the original owners and in June, 1906, was sold to the Haida Copper Company, which began active developments and made plans. for the erection of a gravity tram 2,000 feet in length to the beach and for a wharf and ore bunkers. In April, 1907, these improvements were completed and the company made shipments of ore to the Hadley smelter. Early in the summer, however, operations were suspended, and the mine has since been idle. The mine is developed by a tunnel 120 feet in length connecting with a shaft 35 feet deep, which in turn connects with a surface pit on the ore body. Exploratory drifts have been extended from the tunnel, and prospect pits and short tunnels have been driven at other points on the property.

Ore body.-The ore body is an irregular magnetite mass carrying chalcopyrite in a gangue of garnet and epidote. The country rock in the immediate vicinity is made up of greenstone, tuff, and con- 
glomerates, though just below the mine workings a belt of intrusive diorite is exposed which forms the western half of the ridge and probably underlies the ore body. The deposit is developed by an open pit over an area about 50 feet in diameter. This is undercut by a tunnel at a depth of 30 feet, and though the magnetite is exposed at this depth, chalcopyrite is not so abundant. To the northeast the ore body is limited by a fault plane striking nearly east and west and dipping $75^{\circ} \mathrm{S}$. Other slipping planes striking at different angles were noted in the ore body and inclosing rock.

OTHER PROSPECTS.

Copper Center group.-The Copper Center group of claims lies 1 mile north of the Mammoth group at an elevation of 400 feet. It was located in April, 1907, and in July was bonded to mining men who undertook its development. Several shafts from 10 to 30 feet deep were sunk within an area 300 by 120 feet. In all of these shafts and surface cuts a magnetite and chalcopyrite ore associated with garnetepidote and hornblende gangue is exposed. The deposit is apparently flat-lying, though the amount of work done is hardly sufficient to prove that it does not continue in depth. It is also probable that further investigations at a greater depth will reveal deposits at other points on the property. The country rock is largely greenstone tuff and conglomerate which is underlain by the granodiorite exposed down the hillside to the southwest. The area is densely covered by an undergrowth which renders prospecting difficult. The dip needle has been successfully used within this area and the deposit just described was located by it.

Charles prospect.-The Charles property lies about 1 mile southeast of the Mammoth group at an elevation of 380 feet and 5,000 feet from tide water. It was located in May, 1907, and only a small amount of work has been done on it. The mineral body exposed in a cut 20 feet long and 10 feet deep consists of chalcopyrite masses associated with some magnetite in a garnet gangue which replaces the greenstone tuff country rock.

Granodiorite composes the hill just west of this prospect, but was not exposed near the mineral body. Dikes of diabase crosscut the ore body and are evidently of later intrusion. Besides the values in copper, the ore is said to carry high values in both gold and silver.

Brown \& Metzdorf prospect.-The Brown \& Metzdorf prospect is located three-fourths of a mile south of the Charles prospect and onehalf mile from Kasaan Bay, at an elevation of 310 feet. The ore body is a mineralized mass of garnet rock carrying chalcopyrite and pyrite exposed over a width of 10 feet, showing a banded structure and evidently replacing the bedded quartzite and greenstone tuff coun- 
try rock. A wide belt of limestone is exposed in bluffs along the trail just below this prospect.

Peacock and Tacoma claims.-These claims, about 3 miles southeast of Kasaan post-office, are the property of the Grindall Mining and Smelting Company (fig. 1). The Tacoma claim is located along the beach, where open cuts have been made on ore exposures that are covered at high tide. The ore is confined to the garnet-epidote rock and occurs in irregular patches or is finely disseminated, but nowhere in large bodies. In the beach cuts a small amount of ore is exposed, and above this at an elevation of 50 feet is a tunnel 60 feet in length entering the hill in a northeasterly direction. This tunnel crosscuts a wide belt of garnet-epidote rock containing some chalcopyrite: Other open cuts expose small amounts of ore at several places, but no large ore masses have been developed.

The Peacock claims adjoin the Tacoma claim on the north and continue to the center of the peninsula. At a point 600 feet from the beach and 120 feet above tide a tunnel 45 feet long exposes a belt of garnet-epidote contact rock containing magnetite and a small amount of chalcopyrite. Still higher, at 325 feet; a second tunnel 30 feet long, following the contact of a diabase dike, exposes a similar mineral-bearing rock. Here also dikes of felsite and basalt occur, and stipping planes fault the mineral body in various directions. The amount of development on these properties has not been sufficient to disclose ore bodies large enough to justify mining, but systematic prospecting may open up deposits of value.

"Hole in the wall" prospects.-The small cove known as " Hole in the wall " lies on the north side of the harbor at Hadley, and along its shores and west of it a number of claims have been located, among which are the Plumley group and the Eureka, Sunrise, Pennsylvania, Venus, and Pelaska claims (fig. 1). On the Hilma claim of the Plumley group, at a point one-half mile northwest of the head of the cove and 310 feet in elevation, a tunnel 25 feet in length has been driven along the contact of an altered limestone belt with a dioritic intrusive, in which small masses of chalcopyrite are exposed in a garnet-epidote-calcite contact rock. On the Eureka claim at tide water similar contact deposits are being developed and are reported to be of considerable extent. The Sunrise claims, three in all, are located west of the "Hole in the wall," and on these claims at points along a gulch small ore masses occur replacing limestone beds at or near their contact with granodiorite. At 1,050 feet elevation this contact aureole is 25 feet in width and contains considerable magnetite and chalcopyrite ore which shows much surface alteration. On the south slope of the hill at 950 feet elevation is an open cut exposing a highly crystalline marble, slightly banded, striking N. $65^{\circ}$ E. and dipping $60^{\circ} \mathrm{NW}$. This marble overlies the contact rock which 
carries small amounts of the copper ore. On the Pennsylvania claims southeast of the Sunrise claims an open cut following a felsite dike at 850 feet elevation exposes a small vein 2 to 3 feet wide consisting of pyrite with small amounts of chalcopyrite. The prospects on the Venus claims show contact deposits similar to those exposed on the Sunrise claims to the north and are apparently along the same intrusive contact. The Pelaska claim, extending from the head of the cove westward, has been developed by a tunnel over 100 feet in length following a belt of altered limestone intruded by a diabase dike along which occurs the garnet-epidote contact rock carrying some chalcopyrite. This deposit is interesting geologically, but the amount of ore exposed is small.

\section{KARTA BAY.}

GENERAL DESCRIPTION.

The name Karta Bay is applied as a general term to the entire northwest extension of Kasaan Bay. It is a relatively shallow embayment 3 miles in width, including a number of low, wooded islands and shoals, and affording several good anchorages. On the charts, however, the name is applied only to the harbor on the west side of this embayment, on which the Baronovich fishery and a small Indian village are located. The land northwest of this bay is low and is occupied by a "salt chuck" 2 miles in length and by 3 small lakes. To the southwest is a mountain range including. Granite Mountain and other rounded summits less than 4,000 feet in elevation, and to the northeast is a low ridge of hills forming the divide between Karta and Thorne bays. The principal mines in the immediate vicinity are the Rush \& Brown mine and the Venus group to the northwest, and the Goodro claims to the northeast (fig. 4). In 1901, when A. H. Brooks visited this section, none of these properties had been located, and not until 1904 were the copper-bearing ore bodies discovered.

The area is occupied principally by stratified rocks ranging from a fine tuff to a coarse conglomerate often showing a development of large hornblende crystals. These bedded rocks are invaded by granodiorite masses, and dike rocks of various composition intrude both the granodiorite and the bedded rocks. The copper ore occurs (1) at the contacts of the granodiorite with greenstone tuff, conglomerate, and limestone, as at the Rush \& Brown mine; (2) along shear zones in the greenstone tuffs and conglomerates, as at the Venus group and Rush \& Brown mine; and (3) in small masses and disseminated particles scattered irregularly through an altered basic diorite, as at the Goodro claims. 
RUSFI \& BROW N MINE.

Situation and development.-The Rush \& Brown property includes eight claims extending from "salt chuck" northwesterly, the principal mine workings being located on the Iron Cliff claim at an elevation of 300 feet, and about 2 miles from the wharf at the head of the bay (figs. 4 and 5). In 1904 this property was prospected by long trenches and open cuts, and a shaft 25 feet deep was sunk on

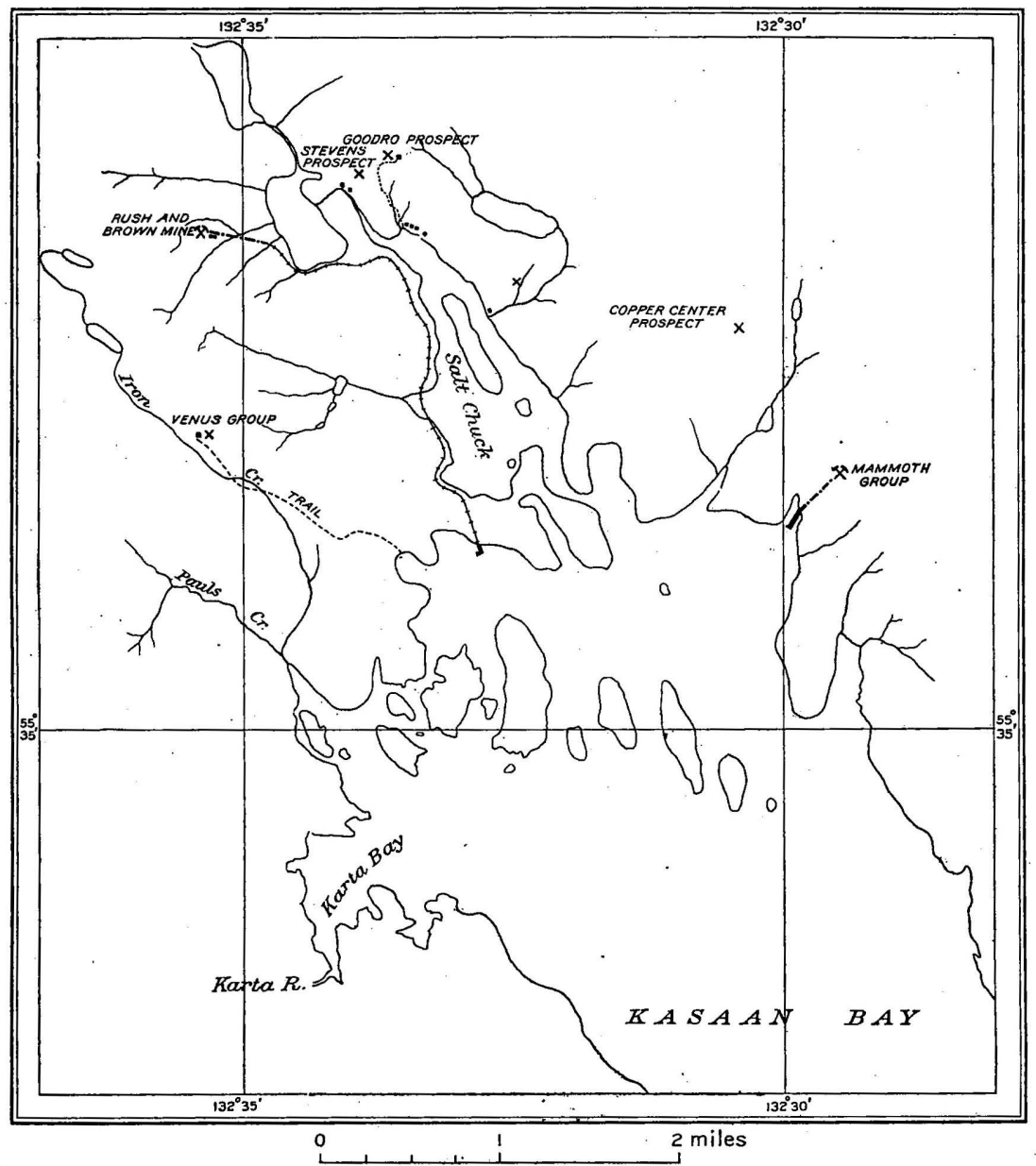

Fig. 4.-Map showing mines and prospects adjacent to Karta Bay.

the ore body. In 1905 it was leased by the Alaska Copper Company, and a new shaft was started 120 feet south of the old shaft and sunk to a depth of 100 feet. From the bottom of this shaft the principal ore body, the magnetite deposit, was developed by drifts and crosscuts and a drift was extended to a second ore body, the sulphide deposit, 160 feet farther northeast. At the close of 1907 the greater 


\section{KETCHIKAN AND WRANGELL MINING DISTRICTS, ALASKA.}

portion of these ore bodies had been stoped out and the shaft sunk an additional 100 feet to a point from which a 200 -foot level was started. The ore from the mines is transported by a gravity tram
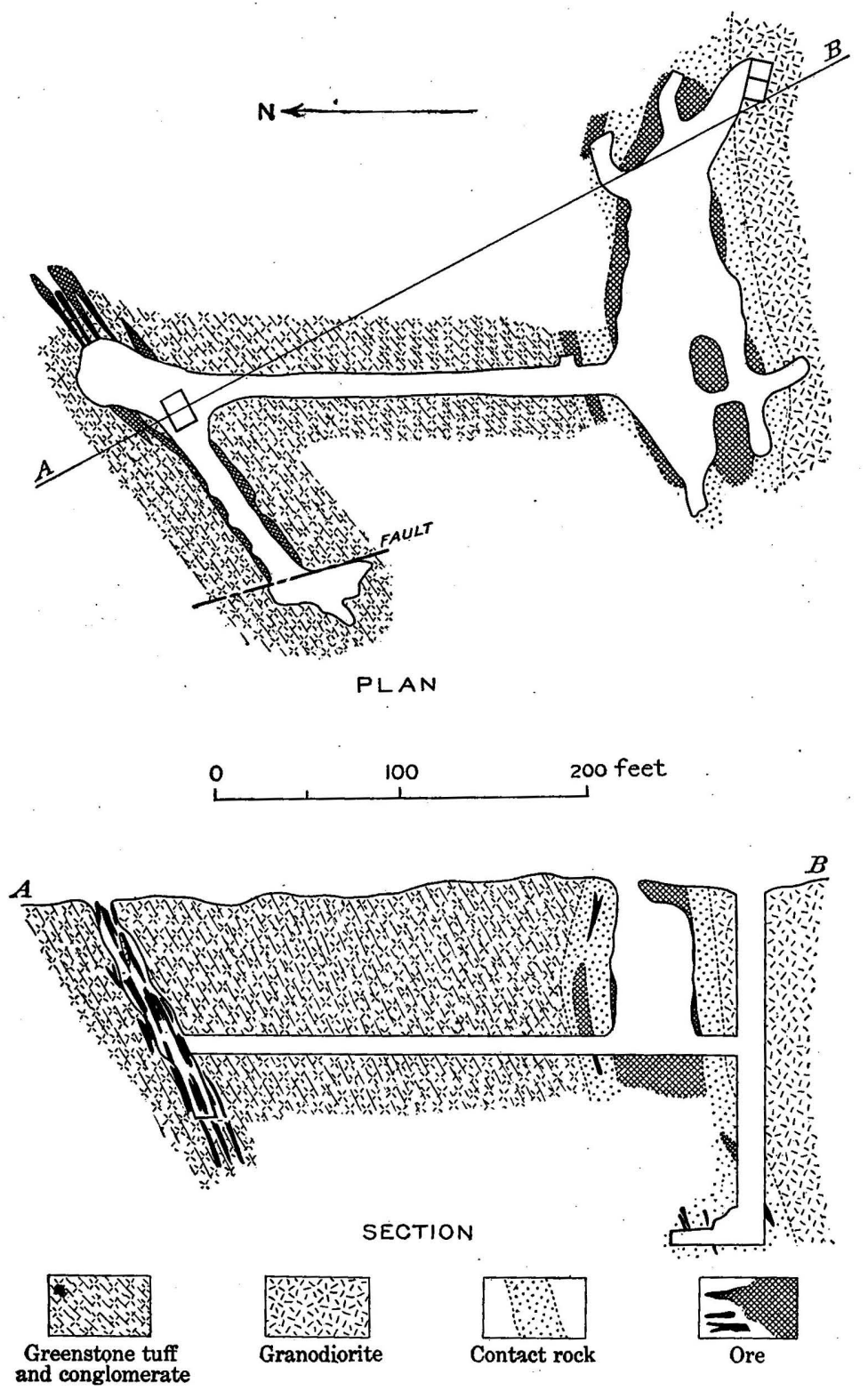

FIG. 5. - Sketch plan and section of mine workings, showing ore bodies at Rush \& Brown mine.

to ore bunkers one-fourth mile below the mine and thence by a railroad $2 \frac{3}{4}$ miles long to the wharf at the head of the bay, where ore bunkers of 2,000 tons capacity have been built. During 1906 ore 
was shipped to the smelter at Coppermount, and in 1907 shipments were made to the Tyee smelter at Ladysmith, British Columbia.

Ore bodies.-Two ore bodies have been developed at the Rush \& Brown mine. One is a contact metamorphic deposit consisting of a copper-bearing magnetite body 100 feet long by 30 feet wide in a garnet-epidote-calcite gangue lying between granodiorite and an indurated greenstone tuff, the line of contact striking nearly east-west. The other deposit, 160 feet to the north, occupies a shear zone in the greenstone tuff and conglomerate beds, and is a sulphide body. composed of pyrite and chalcopyrite in a quartz-calcite gangue, which is 4 to 8 feet in width and has been developed over a length of 85 feet. The strike of this sulphide deposit is northeastward and its dip $60^{\circ}$ SE. toward the larger deposit.

VENUS GROUP.

The Venus group of claims is located on Iron Creek $1 \frac{1}{4}$ miles from the head of Karta Bay and about 1 mile south of the Rush \& Brown mine (fig. 4). This property was located in 1904 and a magnetic survey made. Within the area of maximum attraction a pit was sunk and a trench 50 feet in length was made through the overlying débris, exposing the magnetic deposit. Below these surface excavations, which are at an elevation of 250 feet, a tunnel 75 feet in length has been driven which crosscuts 50 feet of débris and 25 feet of country rock, and at its face exposes ore. The country rock is an indurated greenstone tuff with interstratified quartzite beds, the ore occupying a shear zone. Associated with the ore is considerable sphalerite and pyrrhotite with quartz and calcite as gangue minerals.

GOODRO CLAIMS.

The Goodro claims, also known as the Joker group, are located one-half mile from the head of the "salt chuck" entering Karta Bay (fig. 4). The surrounding area is relatively low, the claims being located on a knoll about 400 feet in elevation. The copper deposit at this locality is of special interest because bornite is the dominant ore and it is the only locality in southeastern Alaska where bornite has been found in quantity. This ore occurs in small masses and disseminated particles associated with epidote, feldspar, and biotite, and is inclosed in a basic diorite which is largely replaced by these minerals. Native gold and considerable chalcopyrite also occur with the ore, and near the surface small amounts of chalcocite and native copper were noted. The diorite forms an extensive belt half a mile wide striking in a northwesterly direction (see Pl. I). Laterally this mineralizacion is exposed across a width of 60 feet and for about 100 feet in length. It has been developed by a surface 
pit 12 feet deep, by a cut 70 feet long, and by a tunnel 125 feet long. which crosscuts the ore-bearing mass 90 feet below the surface and 90 feet from its mouth. Slipping planes were observed at several points, but do not appear to have caused any noteworthy displacements. In an open cut a diabase dike is exposed which is evidently later than the ore deposition. Early in 1907 an ore shipment was made to the Hadley smelter and is reported to have yielded good values in both copper and gold.

\section{TOLSTOI BAY.}

GENERAI， DESCRIPTION.

On the north end of Kasaan Peninsula, adjacent to Tolstoi Bay, which forms a good anchorage to the west, considerable prospecting has been done and numerous locations have been made, but none of the properties have been developed beyond the prospecting stage. The small promontory here is composed largely of the granodiorite intrusive masses which are exposed at Tolstoi Point and along the eastern slope of the mountain. On the western slope and along the east shore of Tolstoi Bay the rock exposures are principally of tuffaceous sandstone and conglomerate and occasional strata of limestone. Both the stratified and the intrusive rock masses are crosscut by dikes of porphyry and diabase (see Pl. I). The ore bodies are contact metamorphic deposits similar in character to those shown at the mines on the southern part of the peninsula. They are lenticular masses of magnetite carrying chalcopyrite and associated with garnet, epidote, calcite, and quartz, and inclosed in the bedded rocks near the intrusive granodiorite contact.

IRON CAP GROUP.

This property, also known as the Mahoney group, consists of two claims located on the northwest slope of Tolstoi Mountain at an altitude of 1,000 feet and is reached by a trail $1 \frac{1}{2}$ miles long starting from a cove 2 miles southwest of Tolstoi Point (fig. 1). In 1901 this property was prospected to a considerable extent by open cuts along a gulch and by several hundred feet of diamond-drill holes, but since that time it has been idle. The country rock consists principally of tuffaceous greenstone intruded by syenitic dikes of considerable width which are apparently related to the ore deposits. Three ore bodies have thus far been located, the largest being 20 feet in width and traceable for 50 feet in length, the major axis striking N. $45^{\circ} \mathrm{W}$. A second ore body, separated from the first by a 30 -foot dike of an altered intrusive syenite, is 12 feet in width and is limited on the foot-wall side to the southwest by a fault plane showing a considerable gouge seam, and toward the hanging wall grades into a garnet-epidote contact rock. The third ore body, which lies just 
above the other two at an elevation of 1,080 feet, appears to be a flat-lying magnetite deposit only a few feet in thickness.

WALLACE GROUP.

The Wallace group includes four claims situated on the southeast slope of Tolstoi Mountain between 800 and 1,600 feet in elevation (fig. 1). At several points on this property small scattered masses of copper ore are exposed, but at no place have investigations been sufficient to determine the extent of these deposits. The uppermost ore exposures have been opened by a short tunnel in which a vein of garnet-epidote rock is shown containing chalcopyrite and striking $\mathrm{N}$. $15^{\circ} \mathrm{W}$. and dipping $20^{\circ} \mathrm{SW}$. At the lower openings a magnetitechalcopyrite ore is exposed, but the bodies do not appear to be extensive.

TOLSTOI GROUP.

The Tolstoi group of claims is located south of the Wallace group, just below the summit of Tolstoi Mountain (fig. 1). The ore bodies are low-grade magnetite-chalcopyrite masses similar to those on the Iron Cap group, but they have not been so extensively prospected. No developments more than the required annual assessment work have been accomplished on this property.

BIG FIVE CLAIM.

The Big Five claim lies half a mile east of Tolstoi Bay, on the trail to the Iron Cap group, at an elevation of 370 feet (fig. 1). A tunnel 50 feet in length and a shaft expose scattered masses of chalcopyrite, pyrrhotite, and pyrite in a gangue of garnet, epidote, and calcite, the deposit being 10 feet wide. This deposit is a replacement in limestone beds, and many slipping planes, defined by gouge seams, traverse both ore body and country rock. Assessment work only is done on this claim each year.

\section{KASAAN BAY PROSPECTS.}

SUNNY DAY GROUP.

The Sunny Day group of three claims is located on the south side of Kasaan Bay, opposite Kasaan village. The vein follows the hanging wall of a wide porphyry dike striking N. $65^{\circ}$ E., with vertical dip, and carries chalcopyrite with low gold and silver values. It has been traced for some distance by means of surface exposures and open trenches and found to vary not only in width but also in mineralization. The porphyry dike invades a complex of highly metamorphosed greenstones, with occasional marble bands and bosses of diorite. A tunnel begun several hundred paces from the shore has been driven 150 feet to undercut the vein, but so far has failed to do so. 
SHELTON GROUP.

This group of two claims is situated on the east side of Twelvemile Arm about 3 miles south of Hollis and at an elevation of about 1,000 feet. The vein outcrops in the beds of a small mountain creek and has been further investigated by a short tunnel and an inclined shaft 25 feet deep. The vein strikes N. $20^{\circ}$ E., dips $65^{\circ}$ SE., and occurs in a fractured limestone belt, which is an integral part of a formation including chlorite and greenstone schist and phyllites. In the tunnel well-marked slipping planes lined with gouge and slickensided were observed. This vein, which averages perhaps 6 feet in thickness, contains pyrite, chalcopyrite, and malachite in a quartz-calcite gangue, and is reported to carry values of copper with some gold and silver. Before actual mining can begin at this point, however, the vein must be exploited further and its probable extent determined.

\section{NIBLACK ANCHORAGE.}

GENERAL DESCRIPTION.

Niblack Anchorage is a small embayment and harbor 2 miles in length on the east side of Prince of Wales Island; its entrance, which is but 100 yards wide, connects with Moira Sound. The topographic relief in the vicinity is abrupt, the mountains rising to altitudes between 1,500 and 2,000 feet within a mile of tide water. A broad. valley extends northwestward from the head of the bay and is occupied by two small lakes, the lower, Myrtle Lake, being threefourths of a mile long and 90 feet above sea level, and from this fall sufficient power for mine purposes can be obtained (fig. 6).

The rock exposures in the vicinity of Niblack Anchorage consist of various types of greenstone schist with occasional bands of quartzite, altered grits, and quartz-sericite schist. They have a general N. $60^{\circ}$ W. strike and dip from $60^{\circ}$ to $70^{\circ} \mathrm{SW}$. In places slickensided surfaces and gouge seams were noted, showing evidence of considerable faulting at various angles to the lines of bedding. The only intrusive rocks in the vicinity of the ore bodies that intersect these bedded rocks are occasional dikes of diabase. On the ridge north of Niblack Anchorage and also to the south in Moira Sound (see Pl. I) a granitic intrusive was exposed.

Pyrite and occasional particles of chalcopyrite are distributed widely throughout this rock complex, but the sulphide minerals are rarely present in amounts sufficient to warrant exploration. A zone of such mineral concentration occurs at the Niblack mine and has been developed across a width of 250 feet, its trend being northwest up the mountain slope. 
The ore bodies in this zone occur as mineralized bands; veins, and lenticular masses, usually parallel to the rock cleavage, which is also the bedding plane. The bodies which are of most importance consist essentially of a massive sulphide ore, and vary from 10 to 100 feet in length and from 5 to 20 feet in width, and extend from 50 to 100 feet in depth. Many faults are present and have important bearing on the shape and extent of the ore bodies. The ore minerals are principally chalcopyrite and pyrite, with small amounts of sphalerite,

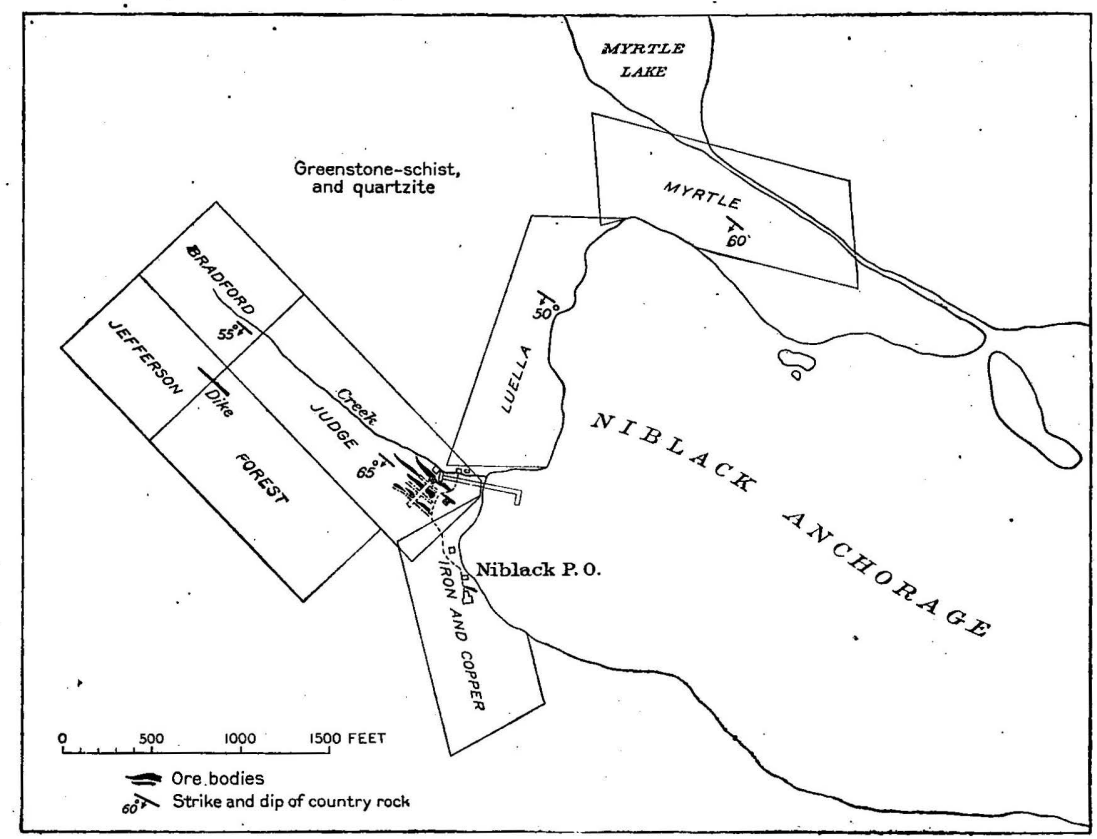

FIG. 6-Map showing position of mine at head of Niblack Anchorage.

the chalcopyrite occurring principally in the greenstones, while the pyrite occurs abundantly in both the greenstone and the sericite schists.

\section{NIBLACK MINE.}

Situation and development.--The Niblack mine, located on the Judge claim of Lookout group No. 2, is situated on the southwest side of the anchorage and but a few hundred feet from tide water. This property was first developed in 1902-3 by the Wakefield Mineral Lands Company and in 1904 was leased by the Niblack Copper Company, the present operators. The principal mine workings are on the Judge claim close to tide water, where the copper ore was first discovered (fig. 6). At a point 150 feet from and 30 feet above high tide is a two-compartment shaft inclined at an angle of $68^{\circ}$. From 
this shaft four levels have been extended at depths of 50,100,150, and 225 feet from the surface; and during 1907 the shaft was extended an additional 75 feet in depth, from which point the fifth level was opened up. The total amount of underground drifting, including raises and winzes at the close of 1907 , is estimated at about 5,500 feet.

The surface developments consist of a shaft house equipped with a 500-foot steam hoist, a 5-drill air compressor, a wharf 700 feet long extending to deep water, on which ore bunkers have been erected, a power house, a machine shop, a general store, and various other necessary mine buildings.

Ore bodies.-WTree large ore bodies have been opened in this mine, besides smaller veins and masses occurring in the shaft and along the drifts. The north or foot-wall vein, which has yielded a large tonnage of the ore, is 200 feet in length, and averages 20 feet in width, and about 100 feet in depth, having the shape of a drawn-out lens. It extends from the surface to the 100-foot level, is parallel in strike and dip to the greenstone-schist inclosing rock, and pitches northwesterly. It is displaced in depth by fault planes crossing the rock formation at an acute angle and marked by a gouge 2 to 6 inches wide. Where the surface of this fault plane was observed in the stopes its face was grooved and polished. Other slipping planes occur at angles to this main fault and one apparently cuts off the ore body in the face of the northwest drift on the 50-foot level. The south vein, which has been developed principally from the 150foot level, is similar in character, but not so large. In this, as was also noted in the other deposits, the sulphides of iron and copper appear to have replaced the greenstone inclosing rock to considerable extent, and fragments of the altered greenstone are present in the ore mass. These rock fragments are impregnated with the sulphides and often appear to grade into the massive ore without definite dividing lines. On the 225-foot level a newly discovered ore body has been exposed over a length of 90 feet and width of 15 feet. This body was intersected by an altered diabase dike, apparently more recent than the ore deposition. The shaft is being sunk lower in order to investigate this ore body. The smaller ore bodies consist of veinlets a few inches wide, cutting the greenstone in various directions, and seams of sulphide ore in the more schistose rock following the stratification. In the country rock a decided penciling or slight folding occurs in the more schistose beds, forming grooves pitching $50^{\circ} \mathrm{NW}$., along the lines which the ore bodies seem to follow.

The ore minerals are chalcopyrite and pyrite with small amounts of sphalerite and hematite and with some galena, the gangue minerals being quartz and calcite. Besides the copper content, gold and silver, 
amounting to $\$ 1.50$ to $\$ 2.50$ per ton, and 1 to 2 per cent of zinc are present in the ore. The ores also contain considerable iron and sulphur and sufficient silica for smelting purposes.

LOOKOUT GROUP.

The Lookout group of five claims, belonging to the Wakefield Mineral Land Company, is situated on the south slope of Niblack Anchorage between 1,000 feet and 2,000 feet elevation and about 1 mile from tide water (fig. 6). These claims were first located in 1900 , and in 1901 considerable development work was done and the adjacent areas were prospected. No important discoveries, however, were made and only a small amount of assessment work has since been done. The principal developments are on the Conundrum claim, where a 160 -foot tunnel has been driven along a belt of mineralized schist striking $\mathrm{N} .65^{\circ} \mathrm{W}$. and dipping $70^{\circ} \mathrm{SW}$. Along the hanging-wall side of this belt is a schistose greenstone, containing stringers of mineral-bearing quartz. A second tunnel 60 feet in length has been started on the same belt 150 feet above the lower tunnel. On the Lookout claims at 1,600 feet elevation an open cut exposes a mineralized belt of considerable width, consisting of brecciated sericite and greenstone schist intermixed with quartz and small masses of sulphides which also penetrate the schists. These mineralized belts are low in grade and at present can not be mined with profit. The introduction of a concentration plant to obtain a richer product for shipment is under consideration.

COPPER CLIFF MINE.

The Copper Cliff mine, also known as the Dama group, is located on the south side of Niblack Anchorage about 1 mile southeast of the Niblack mine (fig. 6). A large amount of development work was done on these claims in 1903-4 and to some extent in 1905, but. since then the property has been idle. The main workings are on the Dama claim at an elevation of 750 feet and consist of a tunnel 200 feet in length, from which 250 feet of crosscuts and drifts have been extended, and a shaft 40 feet in depth sunk at a point 200 feet above the tunnel. In this tunnel the mineralized greenstone schists are exposed, including lenticular bodies of massive sulphide ore. The latter, however, are smaller and contain less of the chalcopyrite ore than the ore bodies at the Niblack mine. The inclosing country rock strikes N. $50^{\circ} \mathrm{W}$. and dips $50^{\circ}$ to $70^{\circ} \mathrm{SW}$. with a prominent jointing system striking $\mathrm{N} .45^{\circ} \mathrm{E}$. and dipping $70^{\circ} \mathrm{SE}$., and along these planes thin leaves or films of native copper were observed. On the adjoining claims mineralized schist is exposed by open cuts on trenches, but at none of these places were ore bodies of any size observed. 
WAKEFIELD GROUP.

The Wakefield group of claims, property of the Moira Copper Company, lies about 2 miles northeast of Niblack at an elevation of 1,100 feet, on the east side of Luella Lake, and can be reached by trail either from Niblack Anchorage or from the north shore of Moira Sound (fig. 7). From the head of Niblack Anchorage the trail leads over a pass 1,850 feet in elevation and then down to Luella Lake 1,000 feet above sea level. The claims were located in 1904 and have not yet been thoroughly exploited. A shaft 50 feet deep has been sunk exposing an ore body for 25 feet in depth, and several open cuts have been made on a mineralized belt of schist. The country rock is made up of various types of greenstone schist and altered slates and grits, striking $\mathrm{N} .40^{\circ} \mathrm{W}$. and dipping $80^{\circ} \mathrm{SW}$. The ore body is a lenticular mass of chalcopyrite 10 feet in width, its length and depth being undetermined. The mineralized belt of schist is about 60 feet across and contains a large amount of pyrite associated with quartz and epidote.

\section{NORTH ARM OF MOIRA SOUND.}

GENERAL DESCRIPTION.

The entrance to North Arm in Moira Sound lies just north of Niblack Anchorage on the east coast of Prince of Wales Island (fig. 7). It is an inlet 7 miles in length with a northwesterly trend and at its head is a narrow channel terminating in a "salt chuck" or shallow embayment. Just north of the narrow channel a stream 50 feet wide tributary from Mineral Lake enters the bay, and along this stream are the principal mine workings. The rock exposures in this inlet include the various types of greenstone and sericite schists interstratified by beds of limestone usually altered to a banded siliceous marble. At one locality an attempt has been made to quarry one of these marble deposits, but so far with little success. ${ }^{a}$

\section{CYMRU MINE.}

Situation and development.-The Cymru mine is located on the north side of Mineral Creek three-fourths of a mile from the head of North Arm (fig. 7). The ore occurrence at this locality has been known since 1900 and is briefly described by Alfred H. Brooks, who visited this section in 1901. Since that time the claims have been relocated at different times because of a lack of assessment work. Early in 1906 these properties were purchased by the Cymru Mining Company and active developments were begun and considerable ore produced the same year. Mining operations continued until

\footnotetext{
a A description of these marble deposits is given under the heading "Building stones," pp. 191-200.
} 
June, 1907, when all work was suspended. The present developments consist of a shaft 105 feet deep, from which two levels at 50 and 100 feet have been extended, the 50 -foot level connecting with an adit tunnel 184 feet in length. On the surface the veins have been opened to a considerable depth by trenches 4 to 8 feet in width and several hundred feet in length. At a point 350 feet to the west of the shaft an inclined shaft has been sunk 85 feet deep on the same vein. This shaft also connects with an adit level 30 feet in depth, which is 90

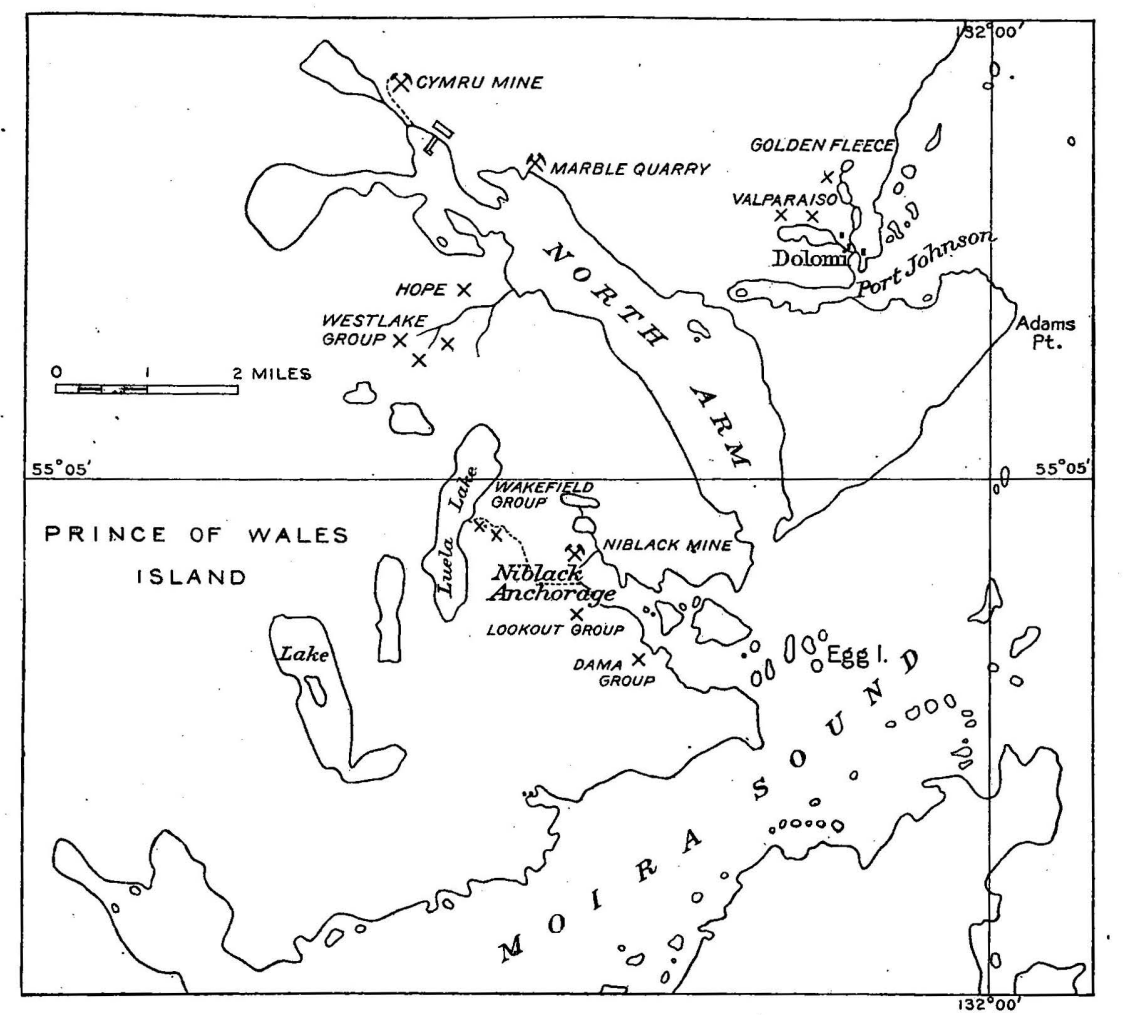

Fig. 7.-Sketch map of Moira Sound, showing location of mines and prospects.

feet in length. A surface tram of 36-inch gage leads from the mine to the ore bunkers at tide water, a distance of 4,200 feet, the cars being propelled by an 8-horsepower gasoline engine. From the ore bunkers, which have a capacity of 1,600 tons, a wharf 40 by 70 feet has been extended to deep water so that ore ships may be loaded directly from the bunkers by conveyor belts.

Ore bodies.-The ore bodies are vein deposits from 1 foot to 10 feet in width, inclosed in a limestone country rock striking N. $60^{\circ} \mathrm{W}$. and dipping $65^{\circ} \mathrm{SW}$. The limestone is interstratified with quartzite and greenstone schists and in many places is banded and altered to 
marble. In these beds faulting planes occur, showing small displacements and shear zones. Four veins parallel with the stratification of the inclosing rocks have been exposed by surface trenches all within a distance of 100 feet of one another. The ore contained in these veins consists of pyrite and chalcopyrite in a gangue of quartz and calcite: Small transverse veinlets also occur in the wall rock adjacent to the veins, in which small ore masses are present, and the rock itself is at many places impregnated by the sulphide minerals. Surface oxidation or weathering along the vein outcrops has produced secondary ores, essentially malachite and limonite, but these are practically absent in the underground workings.

\section{SKOWL ARM.}

GENERAL DESCRIPTION.

Skowl Arm, an inlet 12 miles in length, has its entrance due west from the south end of Kasaan Peninsula, and 4 miles inland is the mouth of McKenzie Inlet, the south branch of Skowl Arm (fig. 8). The head of Skowl Arm is only 6 miles from Cholmondeley Sound,

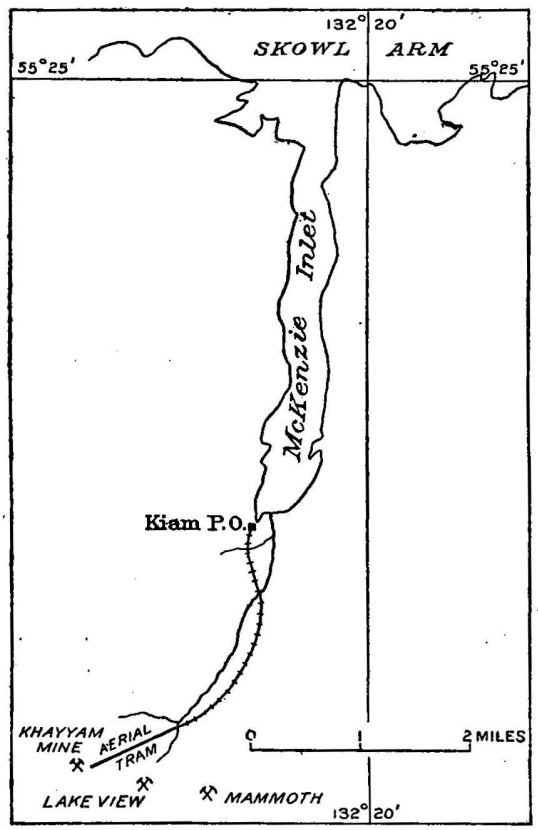

FIG. 8.-Sketch map of McKenzie Inlet, showing mine locations. but the intervening land rises to a high elevation. The shores of this arm are abrupt and the surrounding mountains rise to altitudes of 3,000 feet or more. The channel itself is free from dangers to a point 1 mile beyond the mouth of McKenzie Inlet. Beyond this point and also in McKenzie Inlet are many reefs and rocky islands, rendering navigation dangerous.

The rock exposures around the shores of this inlet are composed largely of a complex of dioritic and granitic intrusives which invade the older limestone and greenstone-schist strata exposed along the north shore of the inlet and to the south in Cholmondeley Sound. Within this area of igneous rocks are included belts of schist, gneiss, and shear zones, and it is in these that the ore bodies are found. The principal ore deposits at the head of McKenzie Inlet consist of masses and heavily mineralized portions of the schists containing essentially pyrite with chalcopyrite. 
KHAYYAM MINE.

Situation and development.-The Khayyam mine, operated by the Omar Mining Company, is situated 2,500 feet above sea level on the summit of a mountain ridge 2.8 miles in an air line southwest of Kiam, a mining camp on McKenzie Inlet (fig. 8). - This property was first located in 1899, and from 1901 to 1905 mine developments on a considerable scale were accomplished and transportation facilities were extended to tide water. In 1906 operations were suspended, but in July, 1907, were again resumed, and were in progress until October. The mine workings consist of several long tunnels 60 to 680 feet in length at elevations of 2,000 to 2,500 feet above tide water. From these workings an aerial tram 1 mile in length carries the ore to bunkers in the valley bottom, whence it is transported over a surface tram $2 \frac{1}{3}$ miles long to ore bunkers at tide water, where it is loaded into boats and shipped to the smelter.

Ore bodies.--In general the ore bodies are elongated lenses of sulphide ore coinciding in strike and dip with the schistosity of the inclosing rock. The surrounding formations vary greatly and consist chiefly of banded basic hornblende gneiss (altered diorite) interbanded with more siliceous gneiss belts, the trend of the structure being $\mathrm{N}$. $85^{\circ} \mathrm{W}$. and the dip $80^{\circ}$ to $90^{\circ}$ north. Several diabase dikes were noted intruding this complex of altered igneous rocks, and one dike 30 feet in width striking $\mathrm{N} .65^{\circ} \mathrm{W}$. at a slight angle to the schistosity can be traced nearly a mile. These dikes are of relatively recent intrusion and have played no part in the formation of the ore bodies. Two systems of joint planes are present along which faulting has occurred. The one system strikes N. $80^{\circ}$ E. and dips $80^{\circ} \mathrm{S}$. with an almost horizontal pitch indicated by striæ and grooves along the fault planes. The second system strikes north and south, dips $60^{\circ}$ to $80^{\circ} \mathrm{E}$., and pitches $60^{\circ}$ to $70^{\circ} \mathrm{N}$. At one point a fault of this system limits the ore body and is defined by gouge and broken rock. Many quartz veinlets are present along this transverse system of jointing cracks. The ore bodies are probably genetically related to the diorite, and particles of the sulphide minerals are finely disseminated throughout this rock where massive and less altered. The contacts of the ore masses are usually well defined, but in some places the ore is "frozen" to the walls.

The ore bodies have been exposed on the surface by open pits and trenches and have been crosscut at a depth of 50 feet by the Powell tunnel 220 feet in length. In this tunnel four ore bodies varying from 6 to 20 feet in width, along which 350 feet of drifting has been extended, are exposed. These ore bodies are all limited on the west by a fault plane, the displacement of which is not known. The Kimball adit tunnel, 350 feet lower than the Powell tunnel and 680 
feet in length, crosses the formation so as to intercept all of the ore bodies exposed above it, but encounters no mineral bodies, and exposes only the banded and jointed diorite in which sulphides or iron in scattered particles occur locally. From the observations in the tunnels and surface openings the ore bodies appear to have the form of irregular elongated lenses nearly vertical in position, with the
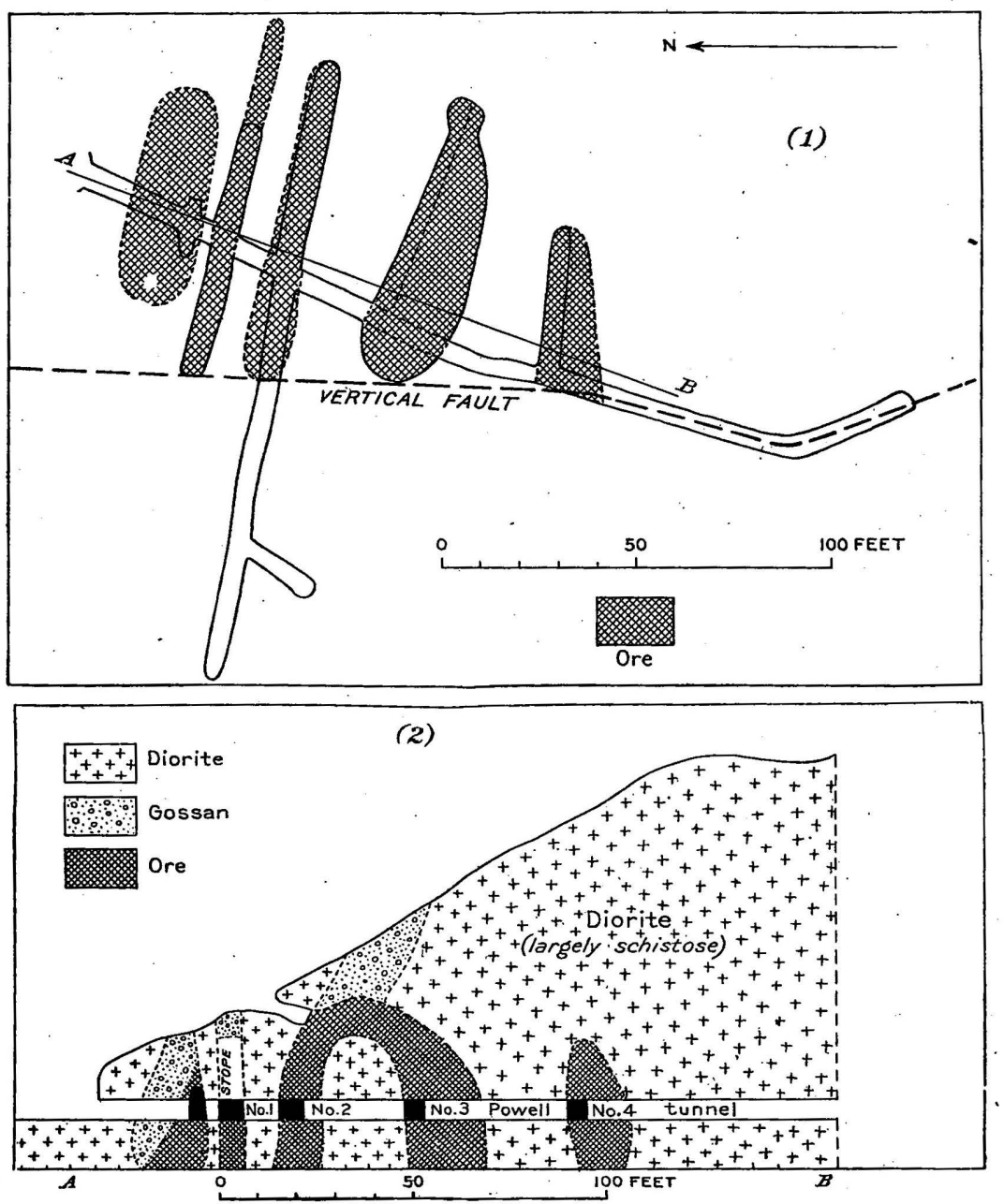

Fig. 9.-Plan and cross section of Khayyam mine workings, showing positions of ore

major axis parallel with the schistosity of the inclosing rock (see fig. 9). The main ore zone has been traced for 500 feet or more in length and is about 50 feet wide. Transverse faulting has displaced these bodies considerably at some points. The mineral content of these irregular deposits is chiefly pyrite with disseminated chalcopyrite, a small percentage of pyrrhotite, and some sphalerite and 
magnetite. A sample taken by H. W. Turner ${ }^{a}$ from No. 4 lens in the Powell adit was pulverized and treated with a horseshoe magnet and yielded 7 per cent of magnetitic pyrite or pyrrhotite. From the remaining sulphide the chalcopyrite was separated and each of the three sulphide minerals was then assayed to ascertain whether the precious metals accompanied a particular sulphide. The following results were obtained:

Analysis of sulphides from. Khayyam mine, skowl Arm, for gold, silver, and copper.

\begin{tabular}{|c|c|c|c|}
\hline . & Goid. & Silver. & Copper. \\
\hline Ohalcopyrit & $\begin{array}{r}\text { Per cent } \\
0.16\end{array}$ & $\begin{array}{r}\text { Per cent. } \\
3.60\end{array}$ & $\begin{array}{r}\text { Per cent. } \\
29.97\end{array}$ \\
\hline $\begin{array}{l}\text { Pyrrhotite } \\
\text { Pyrite- }\end{array}$ & $\begin{array}{l}.03 \\
.03\end{array}$ & $\begin{array}{r}.62 \\
.40\end{array}$ & $\begin{array}{r}2.67 \\
2.32\end{array}$ \\
\hline
\end{tabular}

The copper content of the pyrrhotite and pyrite is attributed to finely dissem:nated chalcopyrite in them, and the higher content of precious metals in the chalcopyrite suggests that the gold and silver favor this sulphide. A qualitative test of the pyrrhotite ore was made for nickel, but none was found. The values in the ore are essentially in copper and gold, but the sulphur content is considerable, and through this constituent alone the ore may be of value.

MAMMOTH GROUP.

Location.-The Mammoth and Lake View claims are situated about 1 mile southeast of the Khayyam mine at $1,200^{\circ}$ feet elevation, just above the head of the Khayyam surface tram (fig. 8). These prospects are along the same general line of strike and in the same rock formation as the Khayyam deposits, but the ore bodies exposed are lode deposits of fairly uniform width and continuous in extent. The mine developments on these properties consist of two long tunnels and several open cuts. During 1907 work was in progress from July to October.

Ore bodies.-The main workings are on a lode deposit some 20 feet wide and in this the richer ore is concentrated along the hanging wall across a width of 2 feet. The strike of the lode is $\mathrm{N} .75^{\circ} \mathrm{W}$. and $\operatorname{dip} 80^{\circ} \mathrm{N}$., the inclosing rock being the metamorphic schists. The ore mass is composed of pyrite, pyrrhotite, chalcopyrite, some zinc blende, and magnetite, with quartz, calcite, and chlorite occurring sparingly as gangue minerals. The same vein has been exposed on both Mammoth No. 1 and No. 2 claims over a length of 1,000 feet and has been developed principally by two tunnels 180 and 165 feet in length, at elevations of 1,100 and 1,250 feet, respectively. 
Other ore masses and bands of mineralized schist have been found on these claims and investigated by surface stripping and open cuts.

GRAVINA ISLAND.

GENERAL DESCRIPTION.

Gravina Island, containing 102 square miles, is separated from Revillagigedo Island by Tongass Narrows and forms a comparatively low, heavily timbered mountain mass west of Ketchikan. The highest peaks are less than 3,000 feet altitude. Along the northeast and northwest shores of the island rocks of the slate-greenstone belt are exposed. These overlie a succession of older schists, limestones, and occasional conglomerate beds of Devonian and lower Carboniferous ages, which are exposed at Vallenar Bay and along the southeast and southwest shore of the island. Intruding these beds are large masses of diorite which form a considerable portion of the east and west mountain ridges. Intrusive dike rocks of various composition are also present, and on the south end of the island is an area of rhyolitic lava flows and tuffaceous beds (Pl. II).

The mineral deposits consist of ore bodies bearing both copper and gold and occurring in lodes and veins in irregular masses. Copper deposits are being developed in the vicinity of Dall Head and Seal Bay, on the south end of the island, and near Vallenar Bay, on the north end. The gold deposits are confined to the slate-greenstone rocks along the northeast side opposite Ketchikan.

PROSPECTS AT SEAL BAY AND DALL HEAD.

Considerable prospecting has been done on the southern end of Gravina Island, copper-bearing deposits having been discovered and exploited at several localities. The geology of the region is extremely intricate, owing to the great variety of intrusive and extrusive rocks and to the intricate faulting which has affected the entire rock complex. The general topography is rough and is controlled apparently in large measure by the bed-rock geology. The west side of Gravina Island is flanked by a range of hills which join north of Dall Bay with an abrupt ridge running parallel with the southeast shore. The latter ridge consists largely of red-colored porphyritic lavas and tufts, frequently intercalated with calcareous deposits in which traces of fossils are visible. West of Dall Bay banded gneiss covers a large area, and still farther west in a small bay a fossiliferous limestone conglomerate of lower Carboniferous age was discovered, which contains abundant altered eruptives and is underlain to the south by eruptive rocks of various types. Along the shores of Seal Bay a similar conglomerate occurs, but it is less calcareous and without fossil remains. Near Seal Bay. numerous large dikes of pegmatite 
invade the schist, quartzites, and greenstones. The general strike of the schists is about north and the dip vertical or steep toward the east.

The ore bodies occur chiefly along planes of movement in the schists; especially along the planes of bedding and schistosity. In general, deposits are found sporadically and do not appear to persist for any distance along the surface. No ore bodies have yet been developed in depth in this area, and it is probable that their occurrence, both horizontally and vertically, is irregular. The ore is chiefly pyrite and chalcopyrite, carrying some gold, with quartz, calcite, chlorite, and iron carbonate as gangue. With the exception of one claim near Dall Head, the claims in this area have been developed very slightly during the last few years and have changed but little since 1901, when Brooks visited and reported on the principal claims. It will, therefore, be necessary here only to supplement his descriptions with the mention of the few changes that have occurred in the intervening years.

On the Concord group near Dall Head a shaft has recently. been sunk on a 3-foot vein striking N. $20^{\circ}$ $\mathrm{W}$. and dipping vertically in a country rock

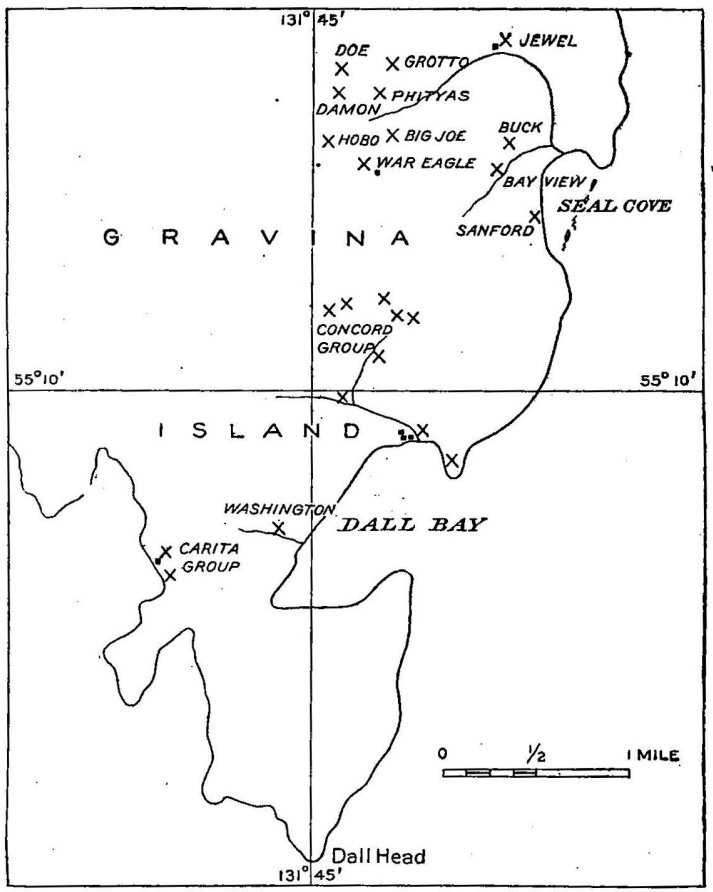

FIG. 10.-Sketch map of Seal Cove and Dall Head, showing Iocations of prospects.

of metamorphosed breccia conglomerate (fig. 10). The metallic minerals are pyrite and chalcopyrite with quartz and carbonate gangue. Nearer the shore on the Sanford group a similar vein has been exposed by open cuts and a short shaft in a much-altered chlorite rock, but high values do not characterize these ore bodies. The claims visited by the writers were: The Jewel claim, on a quartz vein with pyrite striking north and south; the Doe claim on a quartz vein 3 to 6 feet wide, striking N. $20^{\circ}$ E., containing pyrite and chalcopyrite, and inclosed in a siliceous chlorite schist; the Buck claim, on a wide quartz vein in altered quartzite and schist, which is reported to 
assay well in gold and copper; the Damon and Plutyas claims, on a quartz vein heavily mineralized with pyrite and striking N. $20^{\circ} \mathrm{W}$. in a banded chlorite country rock; the Bay View claim, on a quartz vein with pyrite and chalcopyrite, along which a 100 -foot drift has been driven; the Grotto claim, on a wide vein -deposit which has been developed by about 550 feet of drifts and crosscuts, and which oceurs along slipping planes in a complex country rock consisting of chloritic schists, conglomerates, and altered eruptive masses; the Big Joe claim, on a well-defined 10-foot quartz vein striking north and south, which carries pyrite and some chalcopyrite and can be traced for over 3,000 feet in much metamorphosed chlorite schists; the Hobo and the War Eagle claims, on a 10-foot vein with welldefined walls containing pyrite and chalcopyrite; the Algonquin group of four claims and the Black Warrior group of three claims, on small veins of the usual type in chloritic schistose country rock; and the Carita group, located in a cove 1 mile west of Dall Bay, on a quartz vein in calcareous conglomerate carrying stringers of chalcopyrite (fig. 10).

PROSPECTS AT VALLENAR BAY.

During the early mine developments of the Ketchikan district in 1899 and 1900 much work was advanced on a group of claims at the head of and to the west of Vallenar Bay (Pl. II). Shafts were sunk and tunnels driven, but the ore bodies did not prove to be extensive, so that work was soon suspended and has not been resumed. At the Six Point property on the west side of the bay the shaft and tunnel expose a quartz vein apparently following the contact of a diabase dike and containing pyrite with some chalcopyrite, the inclosing country rock being a slaty limestone. The vein is but a few feet in width and pinches to a narrow seam in several places. Southwest of this property on the west coast of the island is the White Knight group of two claims, on which have been exposed small masses of chalcopyrite ore, associated with pyrrhotite and pyrite, inclosed in a greenstone country rock. Practically no work has been done on these mineral deposits and little is known of their extent and value.

DUNCan CanaL.

GENERAL DESCRIPTION.

Duncan Canal is an inlet 20 miles long and three-fourths mile to $1 \frac{1}{2}$ miles wide, on the south side of Kupreanof Island, 3 miles west of Wrangell Straits. At the head of the bay is an extensive tide flat, which runs dry at low water and prevents navigation farther than 12 miles from the entrance. At high water, however, a small launch or rowboat can proceed to the head of the long arm, shown 
on the map, and from this a low marshy valley extends northward across the island to Portage Bay, a distance of 5 miles (fig. 11).

The rock formations of this canal are made up essentially of slates and greenstones along the eastern shore and of calcareous and siliceous schists on the western shore. In the center of the canal is a small island composed of lava showing basaltic structure (Pl. III).

The mineral deposits are all located at the head of the bay and are reached by trails starting from the center arm. - They consist of vein deposits either in the slates and greenstones or in the schists, which contain principally values in copper, with some gold and silver. None of the properties have been developed beyond the prospecting stage, and there. has therefore been no production in this section.

PORTAGE MOUNTAIN GROUP.

This group of claims, owned by the Portage Mountain Mining Company, is situated 4 miles from tide water at the head of Duncan Canal, at an elevation from 2,000 to 3,000 feet on the west slope of Portage Mountain (fig. 11). The rock formations on these properties consist of slates and greenstones intruded by diorite masses and dikes of diabase. The mineral bodies are vein deposits striking northeastward across the general northwest trend of the inclosing slates and greenstones. Several veins at various points have been lo-

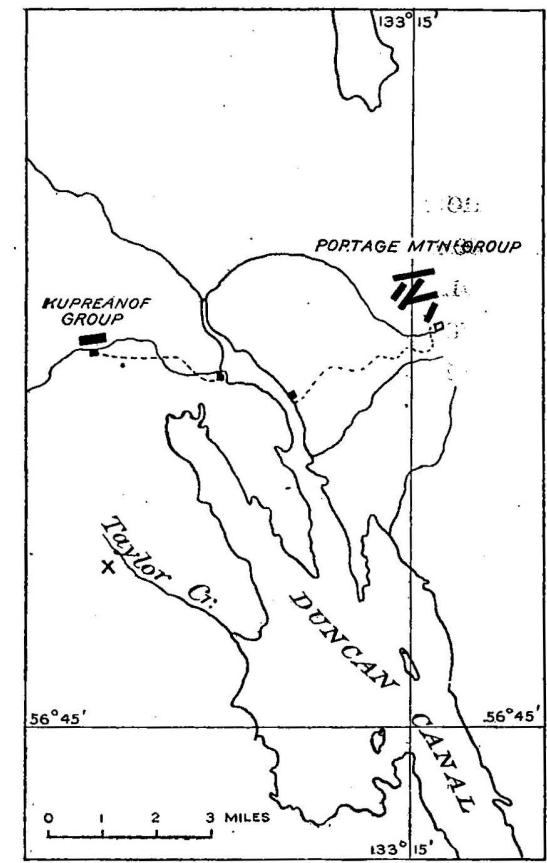

Fig. 11.-Map showing location of Portage Mountain and Kupreanof groups of claims and prospects at the head of Duncan Canal.

cated and prospected by small open cuts. They are but a few feet wide and contain some chalcopyrite and small values in gold and silver, the gangue being quartz and calcite. Although mineral-bearing veins are exposed at a dozen or more points, no large ore bodies have as yet been developed in this area.

KUPREANOF GROUP.

The Kupreanof group of claims, owned by the Portage Mountain Mining Company, lies 6 miles to the east of the Portage group. It is $2 \frac{1}{2}$ miles from the head of Duncan Canal and at an elevation of 
800 feet (fig. 11). This group was first located in 1900 and was well prospected by tunnels and shafts, after which no work was done, and the claims were relocated in 1902. Since that time little more than the annual assessment work has been done. On this property a vein deposit 200 feet long and from 3 to 6 feet wide, having a northeasterly strike and dip of $30^{\circ} \mathrm{N}$., into the mountain, is exposed at several points. The vein material is composed largely of sulphide minerals, pyrite and pyrrhotite predominating and containing chalcopyrite and small values in gold and silver. The gangue is quartz and calcite. A considerable quantity of ore of moderate grade has been developed at this locality, but the position of the deposit is not now favorable for economical mining.

TAYLOR CREEK PROSPECTS.

The prospects up Taylor Creek are located $1 \frac{1}{2}$ miles from West Bay at the head of Duncan Canal at an elevation of 170 feet (fig. 11). These locations were made in 1904, and small developments have since been made. An open cut 30 feet long on the west side of the creek, 100 yards above a cabin, exposes a 12 -foot band of mineralized limestone intersected by quartz veinlets and containing galena, sphalerite, pyrite, and chalcopyrite in small, scattered patches. The strike of this deposit was N. $80^{\circ} \mathrm{W}$. with a dip of $45^{\circ} \mathrm{NE}$., parallel to the bedding planes of the inclosing rocks. Diabase dikes from 1 foot to 6 feet wide, striking northward, were observed in the creek bed intruding the rocks.

\section{GOLD MINES.}

GENERAL STATEMENT.

The gold mines of the Ketchikan and Wrangell districts are few and scattered, and only a small number of the many gold prospects and claims have been developed to the producing stage. Although this metal is widely distributed in all of the older rock formations, both in veins and lodes, it is rarely found in deposits of sufficient size and grade to constitute ore bodies, and those localities where the ore bodies are being mined are necessarily located but a short distance from tide water, where transportation facilities and water power are available. The ore produced by these mines is for the most part free-milling, that is, an ore from which the greater percentage of the gold content may be extracted by amalgamation. It is therefore most advantageously treated in a stamp mill by amalgamation and concentration, and the concentrates alone should be shipped to the smelter for treatment, though in certain instances where a siliceous ore is in demand the gold ore has been sold direct to the smelter. In general the vein ores contain the largest values per ton, 
but the lode ores though lower in grade are present in greater quäntity. Both types of deposit are being mined with profit.

\section{THORNE ARM.}

General description.-Thorne Arm is a wide, deep-water indentation in the southern end of Revillagigedo Island. Its general trend is about north and south across the strike of the underlying country rock. The dissected mountain ridges are less precipitous and lower than those to the east and rarely exceed 2,000 feet in elevation. Abundant evidence of intense ice abrasion characterizes the landscape on all sides. The shore line is abrupt and rocky and near the head of the bay should be approached in boats with caution because of hidden reefs and rocky shelves which extend far into the bay.

The bed-rock geology is complex and structurally intricate (Pl. II). At the upper end of Thorne Arm are crystalline schists and limestones, whereas toward the central part slates and greenstones intruded by large masses of altered basic igneous rocks predominate. The entire complex is further cut by later granitic and dioritic intrusive dikes and stocks similar in character to the Coast Range granodiorite. The southern third of the bay cuts across a wide intrusive belt of granodiorite, which in places contains garnet as an accessory constituent and is noteworthy because of its uniform composition and appearance and the absence of dikes which prevail along the western contact of the Coast Range intrusives. Dike rocks, ranging in composition from diabase to aplite and quartz porphyry, are also common. At the Sealevel mine a dike rock occurs in conjunction with the ore body and was described by. Brooks ${ }^{a}$ as an altered rhyolite (aporhyolite). It is interesting because of its probable bearing on the genesis of the ore. The latest rocks in the Thorne Arm region are postglacial basaltic lava flows, which occur as wide surficial sheets near the northwest head of the bay, also northeast of Sealevel and 5 miles to the south along the shore. These lava flows are of the usual feldspar basalt type with occasional crystals of olivine showing only slight alteration and are in many places vesicular and rough in appearance; columnar jointing characterizes many exposures. Although postglacial, these lavas are covered more or less completely with a dense forest growth.

Mineralization is widespread in this region, especially near the intrusive granite masses. Near Sealevel, where prospecting has been done most energetically, the values are contained in gold- and silverbearing quartz veins included in the sericite and greenstone schists and usually following or crosscutting an intrusive dike rock. The veins trend in a general northeasterly direction and dip southeast at varia-

a Brooks, A. H., Prof. Paper U. S. Geol. Survey No. 1, 1902, p. 65. 
ble angles, frequently filling original slipping planes or fissures bounded by free walls with more or less gouge material.

The ore consists usually of the sulphides, pyrite, pyrrhotite, galena, and sphalerite in variable quantities, together with occasional particles of native gold. The gangue minerals are chiefly quartz and calcite with variable amounts of chlorite, muscovite, siderite, and perhaps feldspar. Considerable gold was extracted from the Sealevel vein several years ago, though in the last few years no work has been done.

The accompanying sketch map (fig. 12) was drawn largely from hastily paced traverses and presents only the general location of the more important claims. Many other claims were observed, but they have been developed so slightly and relocated so frequently that it was not possible in the short time available to unravel the latest location notices and to trace out the latest lines in the maze of interweaving lines of previous locations.

Sealevel mine.--The Sealevel property has been in litigation for several years, and developments have progressed very slowly in consequence. Conditions have changed but slightly since the visit of Alfred H. Brooks in 1901, and his descriptions apply equally well to present conditions. The claim is situated near the northeast head of Thorne Arm and has been developed underground by a 3-compartment shaft 125 feet deep with two drifts along the ore body at the 50- and 125-foot levels respectively, the total length of which with crosscuts is over 1,200 feet. A short tunnel with a winze has recently been driven on the vein at a point 350 feet N. $60^{\circ} \cdot \mathrm{E}$. of the shaft house. The vein is exposed at several other points by open cuts and appears to continue into the adjoining Sea Breeze claim. The surface equipment is adequate and consists essentially of a rock house at an elevation of 250 feet, connected by an inclined tram with a 30 stamp mill at the beach. The power is furnished by a pipe line from Gokachin Falls, 1 mile distant. The stamp mill was in operation from July, 1901, to July, 1902, and considerable gold was recovered, but since that time.it has been practically idle.

The country rock at this claim is composed of various types of schist, the greenstone and calc schists predominating and striking in general west of north with variable dips to the east. Folding is not uncommon and evidences of slipping are noticeable at many points. Dikes of blue altered porphyry crosscut the schists in a direction $\mathrm{N}$. $60^{\circ} \mathrm{E}$. with a dip $65^{\circ} \mathrm{SE}$., and are in turn cut by the mineral-bearing quartz veins, Under the microscope the dike rock appears so highly altered that its original texture is obliterated to a large extent. Secondary quartz, muscovite, calcite, chlorite, and pyrite are present in abundance and indicate only by their general 
grouping the outlines of the feldspars and colored silicates from which they have been derived. The original texture of the rock was porphyritic, with phenocrysts of quartz, plagioclase, and a colored

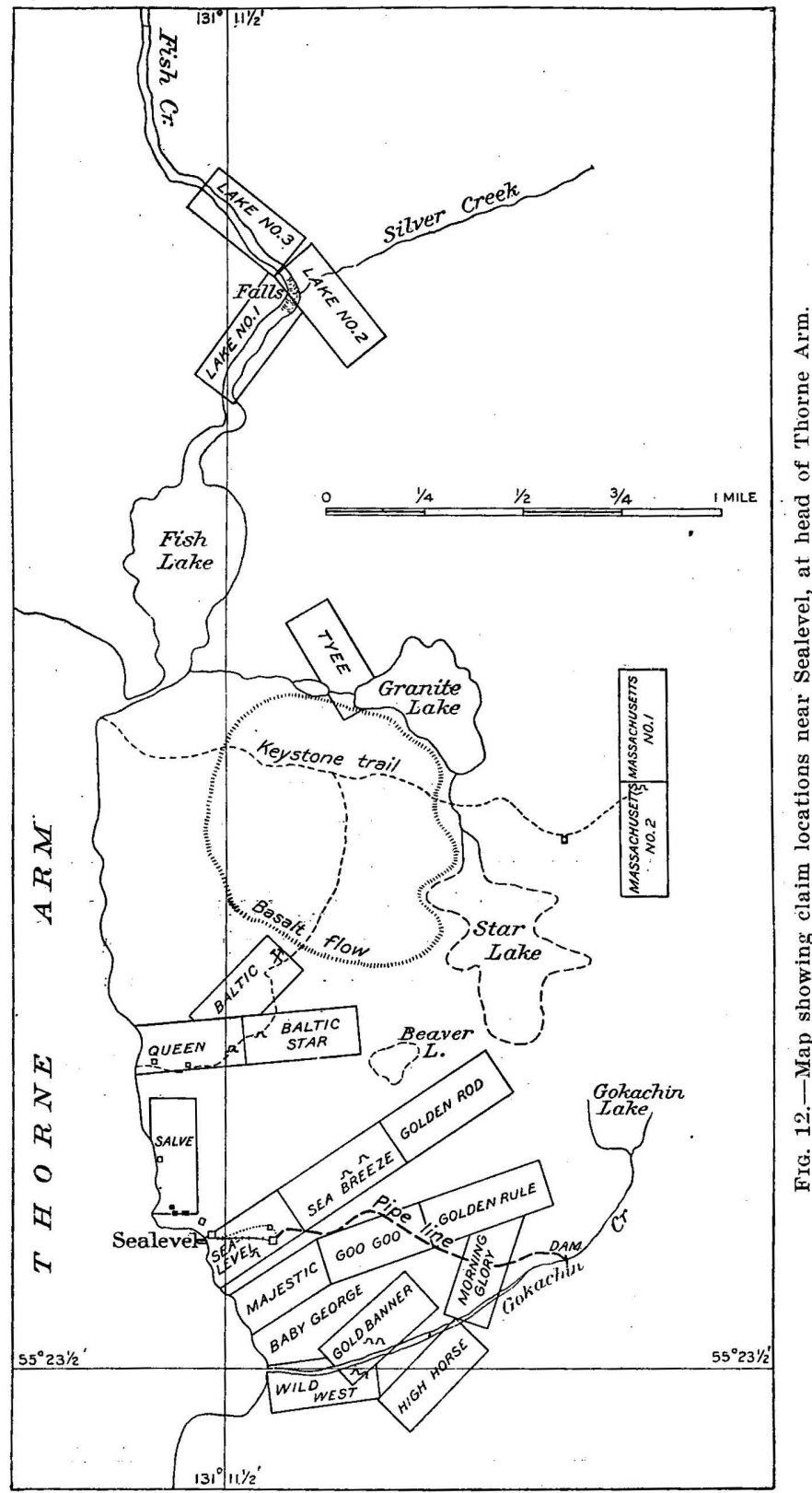

silicate embedded in a fine matrix of similar composition. The general term porphyry applies to rocks of this type, although this particular rock is less siliceous than the usual porphyry. Included 40840-Bull. $347-08-10$ 
within the quartz veins at the Sealevel mine are large fragments of this rock which are said to carry as high values in precious metals as the quartz veins carry. Cubes of pyrite occur frequently in all parts of the dike and the schistose country rock, but the values seem to be confined to the walls adjacent to the vein. Two parallel veins 15 feet apart have been followed by the underground workings, an easterly one 5 feet wide and a westerly one 1 to 2 feet wide. At the time of visit only the 50 -foot level was accessible, the lower workings being filled with water. The two veins there exposed are well defined and show frequent evidence of minor faulting. Numerous offshoots and stringers branch from the main vein into the dike rock without change in general aspect. The course of the belt of quartz veins and mineralization crosscuts the 25 -foot porphyry dike and passes into the adjacent greenstone schist. The degree of mineralization of the veins, however, appears much greater within the limits of the dike than in the adjacent schists. This belt has been traced by open cuts and prospect tunnels for about 2,000 feet and preserves its general character throughout that distance.

The ore consists essentially of pyrite, galena, and sphalerite, with occasional flakes of native gold and a gangue of quartz with some muscovite. The larger percentage of the gold content is said to be free milling, while the value of the concentrates recovered is reported to be moderate. The mine is favorably situated for the economical treatment of the ore.

Sea Breeze claim.-The Sea Breeze claim adjoins the Sealeviel on the northeast and is located on the extension of its mineralized belt. The developments consist chiefly of two short tunnels and numerous open cuts which expose the vein for a long distance. The veins occur frequently in or near a wide porphyry dike, which invades the greenstone country rock under conditions similar to those at the Sealevel property. The quartz veins are, however, less regular and vary in width from 1 to 8 feet. Faulting and intense fracturing and rapid variation in mineralization are characteristic features of this vein. The ore consists of porphyry, galena, and sphalerite, with an occasional speck of native gold in the gangue of white quartz. The values in this vein are reported to be in general low with much variation in metal content within the vein, the content being apparently proportional to the amount of mineralization.

Golden Rod claim.-Although the Golden Rod claim adjoins the preceding claim on the northeast, it is located on a vein of different character outcropping in a different country rock. Several open cuts along the northern slope of a steep hill of granodiorite expose the quartz vein, which at a point 320 feet above sea level was 16 feet wide, with a strike N. $50^{\circ} \mathrm{E}$. and a dip $80^{\circ} \mathrm{SE}$. The granodiorite country rock is aplitic in character and often gneissoid in structure, 
Mineralization is slight and the values are said to be correspondingly low.

Googoo claim.-The Googoo claim was located in 1905 on a western extension of the Golden Rod claim. At the point of discovery a quartz vein 22 feet wide has been developed by a shaft 20 feet deep. To the northeast, however, the vein is only 3 feet wide and has been developed by a tunnel 15 feet long. Free gold, pyrite, sphalerite, and some galena were noted in the vein on this claim, and pockets containing considerable free gold are reported to have been found.

Majestic claim.-The Majestic claim, originally known as the Mother Lode claim, adjoins the Googoo claim on the southwest. On this property a quartz vein 20 feet wide occurs inclosed in the altered schists. The strike of the vein is N. $63^{\circ} \mathrm{E}$. and the dip $80^{\circ} \mathrm{SE}$., and it may represent the continuation of the Googoo vein. Pyrite, sphalerite, and galena were noted in the quartz gangue. The developments consist of an open pit 10 feet deep and a tunnel 10 feet long near the center of the claim.

Golden Banner claim.-The Golden Banner claim, originally located as the Golden Tree claim, is located on Golzachin River about a mile from the beach. The principal developments on this property consist of a tunnel 60 feet in length. The country rock is composed of several types of schist, striking in general $\mathrm{N} .15^{\circ} \mathrm{W}$. and dipping $85^{\circ} \mathrm{SW}$., intruded by a porphyry dike, which forms the hanging wall of the quartz vein at the shaft. The vein varies in width 1 foot to 6 feet and is faulted slightly at several points. At the shaft, which is situated on the crest of the ridge north of Gokachin River, the vein is 3 feet wide, and it can be traced over 150 paces from the shaft in a direction N. $65^{\circ} \mathrm{E}$. with a dip $70^{\circ}$ to $80^{\circ} \mathrm{SE}$. The ore is made up of pyrite, galena, and sphalerite, with occasional particles of free gold, in a quartz gangue. The values, which are probably irregularly distributed, have not been actually determined.

Baby George claim.-The Baby George, which has received very little development, is located at the mouth of Gokachin River. A short prospect tunnel has been driven to expose the quartz vein, which is 10 feet wide and occurs in argillites and greenstone schist.

Wild West claim.-The Wild West claim, a relocation of the Tide Water claim, is situated on the south bank of Gokachin River near its mouth. The ore body consists of several quartz stringers about 1 foot wide, striking N. $60^{\circ}$ E. and dipping $70^{\circ}$ SE., and inclosed in banded argillites and sericite schists. The developments are slight and consist of surface cuts only.

High Horse claim.-The High Horse claim, a relocation of the Monster claim, lies east of the Wild West and has been developed by open cuts and a short prospect tunnel. The vein varies from 6 inches 
to 3 feet in width, strikes N. $55^{\circ}$ E. and dips $75^{\circ}$ SE., and occurs in a complex of schists striking $\mathrm{N}$. $50^{\circ} \mathrm{W}$. and dipping $80^{\circ} \mathrm{NE}$. The ore consists chiefly of pyrite with some sphalerite. Pyrite cubes are also abundant in the adjacent schists.

Salve claim.-The Salve claim is situated north of Sealevel and runs from Russel Point northerly parallel to the shore line. The vein is exposed by an open cut and test pit and is essentially a band of mineralized sericitic schist with few small stringers of quartz. The schists in the vicinity strike in general N. $20^{\circ} \mathrm{W}$., dip. $70^{\circ} \mathrm{NE}$, and show folding and some faulting. Dikes of porphyry cut the schists in a northeasterly direction and at one point are apparently later than the quartz stringers. The ore is pyrite with low values in gold.

Queen and Baltic claims.-The Queen and Baltic claims are situated north of the Salve claim and are both located on a quartz vein which has been exposed by open cuts, two short prospect tunnels, and an inclined shaft 40 feet deep. The vein trends in general east and west, with a steep to vertical dip, and cuts across the cleavage of the inclosing schists, which strike N. $20^{\circ} \mathrm{W}$. and dip $70^{\circ}$ NE. The vein varies in width from 1 to 6 feet and consists of quartz with some pyrite, sphalerite, and low values in gold.

Baltic Star claim.-The Baltic Star lies north of the preceding claims and has been developed still less. The quartz vein is included in mineralized schist and trends N. $60^{\circ} \mathrm{E}$. with a dip $75^{\circ} \mathrm{SE}$. It is $1 \frac{1}{2}$ feet wide and has been traced for 300 feet in length. Pyrite, sphalerite, and galena with low free-gold values constitute the ore, with quartz as gangue.

Tyee claim.-The ore body of the Tyee claim near Granite Lake is noteworthy because it occurs wholly within a wide granite mass. The vein is 4 feet in width, strikes east-west, dips $78^{\circ} \mathrm{S}$., and contains besides quartz small quantities of pyrite, sphalerite, and galena, with low values in gold.

Massachusetts claims Nos. 1 and 2.-The two adjoining Massachusetts claims, originally known as the Keystone claims, are situated northeast of Sealevel. The trail leading to the claims passes over a wide area of postglacial basaltic lava, elevated plateau-like above the surrounding country and remarkably level on top. At the claims a tunnel 80 feet in length and 500 feet in elevation has been driven; also a shaft has been sunk 30 feet on the vein, and a drift from the shaft 50 feet in length and several open cuts have been made. The country rock consists largely of schists with some interbedded greenstones striking north and south and dipping northeast at steep angles. On the dump from the shaft were fragments of granite probably derived from an intrusive dike exposed by the shaft, which at the time of visit was filled with water. At the surface the vein is 5 
feet in width, but in depth it decreases to 6 inches and divides into small stringer veins. The ore consists of pyrite, galena, and sphalerite in a gangue of white quartz. The values in gold are said to be favorable near the surface.

Lake claims Nos. 1, 2, and 3.-These claims have recently been located on Fish Creek near the junction with Silver Creek and the Falls. They have not yet been developed to any extent and nothing definite is known as to their value. The country rock consists of micaceous and greenstone schists. invaded by a granite mass. The

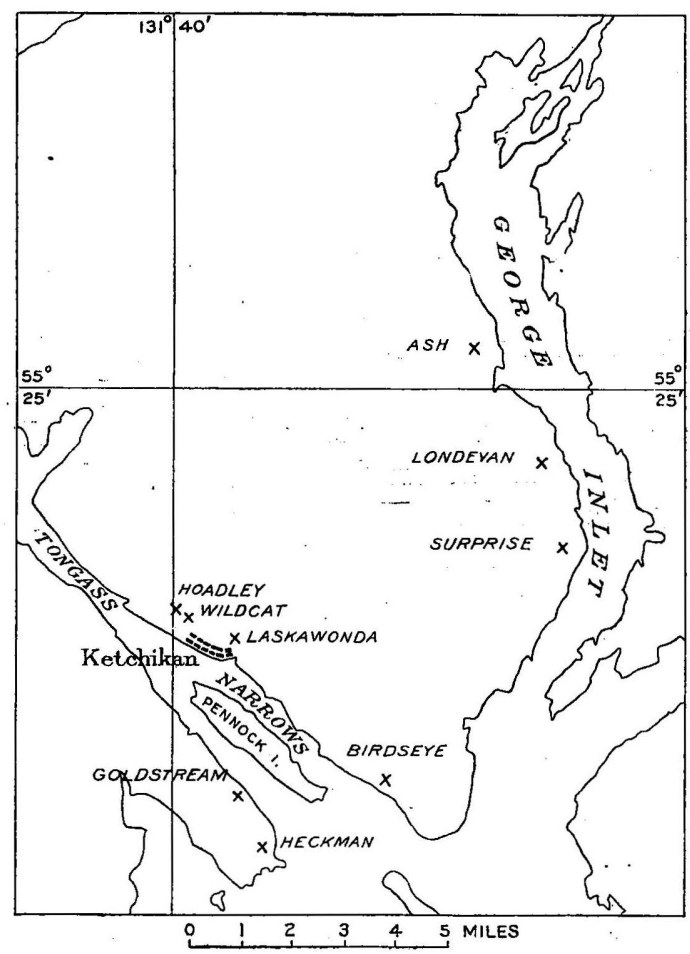

IFIG. 13.-Sketch map showing location of prospect adjacent to George Inlet and Tongass Narrows. included quartz veins are similar in character and contain pyrite, galena, and sphalerite in small quantities. One quartz vein on Lake No. 2 and Lake No. 3 measures 60 feet in width at one point and runs $\mathbf{N}$. $15^{\circ} \mathrm{W}$., with vertical dip across the cleavage of the schists.

\section{GEORGE INLET.}

General description.George Inlet is one of the deep embayments on the southwest side of Revillagigedo I s l and having a length of nearly 18 miles and varying from threefourths of a mile to 2 miles in width (see Pl. II and fig. 13). Starting at its entrance and following inland, the greenstones and argillaceous slates are first exposed for 2 miles along the north shore; a granite belt $2 \frac{1}{2}$ miles wide is then crosscut and is followed by more argillaceous slates with occasional greenstone beds. Toward the head of the inlet the crystalline schists interstratified by belts of marble compose the shore exposures. The general strike varies from N. $10^{\circ}$ to $50^{\circ} \mathrm{W}$. and the dip usually steep to the southwest. The ore bodies so far discovered are all located on the northwest shore of the inlet from 5 to 10 miles from its entrance. These consist of both large and small vein deposits striking parallel and at angles to 
the bedding plane of the schists. The principal values contained are in gold, which in some of the deposits is associated with galena sphalerite and pyrite in considerable amounts.

Peterson group.-This property of four claims is situated close to tide water on the northwest shore of George Inlet about 5 miles from the entrance and has been prospected by open cuts and two short tunnels. The principal vein deposit occurs along vertical slipping planes which parallel the rock structure in strike but intersect the beds in dip. The schist formation at this point strikes N. $35^{\circ}$ W. and dips $50^{\circ} \mathrm{SW}$. The vein varies greatly in width, averaging 15 feet, and is reported to have been traced for 1,000 feet along its trend, its walls being defined by gouge seams. The metallic minerals contained are pyrite, galena, zinc blende, pyrrhotite, in a gangue of quartz, calcite, and graphite. Well-defined gouge planes limit the deposit in many places. The values reported include both gold and silver. Other vein deposits have been exposed on this property, but still remain undeveloped.

Lon-de-Van group.-This property of eleven claims, originally called the Telegraph group, is located on the north side of George Inlet, 5 miles above the Peterson group. On this property six welldefined and persistent veins have been exploited by open cuts and tunnels at different points along their strike. The country rock consists largely of banded argillites and black slates with occasional acidic porphyry intrusives. Two sets of veins occur, an old transverse set filling cross-fracture cracks in the sedimentary complex, and in one instance attaining a remarkable thickness; and a second system filling planes of movement along the beds of the formation and striking usually $\mathrm{N} .10^{\circ} \mathrm{W}$. with variable dip, in general about $50^{\circ} \mathrm{SW}$. Six veins of the second type have been discovered, one of which has been traced for several thousand feet in length. The veins vary from 1 to 4 feet in width and many of them are adjacent to intrusive porphyry dikes. The metallic minerals contained are pyrite, galena, and sphalerite, in a quartz and calcite gangue. Moderate values in gold and silver, the latter in some instances exceeding the gold content, are reported. Only a small percentage of the gold is free-milling, and it will be necessary to concentrate the ore to recover its values. The cross veins, one of which has a thickness of several hundred feet, carry lower values than the strike veins and but a small amount of pyrite, and are therefore still undeveloped. Openings have been made on these deposits at different points extending from tide water to a point a mile from the shore, at an elevation of 1,000 feet. Ashe's group.-This group is located about 3 miles above the Londe-Van group near tide water at a small embayment on the north side of George Inlet. The vein deposit at this point follows a porphyry dike which in turn is parallel to the inclosing slates and schists, and 
has been exploited by a short tunnel and several open cuts. The vein is about 2 feet wide, striking $\mathrm{N}$. $75^{\circ} \mathrm{W}$. and dipping $10^{\circ}$ to $20^{\circ} \mathrm{NE}$., though both strike and dip vary considerably at the different exposures. It contains abundant galena and sphalerite in a quartzcalcite gangue carrying small gold and silver values. The porphyry dike is also impregnated to a small extent with these minerals. The developments on this deposit include a 35-foot tunnel, a short shaft, and several open cuts.

\section{TONGASS NARROWS.}

General description.-Along the shores of the narrow body of water called Tongass Narrows, which separates Rerillagigedo and Gravina islands, greenstone schists and black slates outcrop and trend in general parallel to the shore line (see Pl. II). On the Revillagigedo Island side of the narrows a number of claims have been located, but no ore bodies of importance have yet been developed. The ore bodies include both quartz veins and bedded deposits and frequently occur near intrusive porphyry and aplitic dikes. The mountains east of Tongass Narrows trend parallel to the coast and range from 2,000 to 3,000 feet in elevation. They are composed largely of granite, which intrudes the greenstones and slates. Several of the quartz veins near the contact of the intrusive masses with the sedimentaries are sporadically very rich in free gold, but the average content is low.

Hoadley group.-The Hoadley group includes five claims and is located about 2 miles north of Ketchikan and one-half mile from the beach (fig. 13). The developments consist chiefly of open cuts and short drift tunnels, besides an arrastre in which the free-milling ore is treated. The country rock consists of siliceous and argillaceous schists striking northwest and intruded by large granitoid dikes, usually parallel to the formation and ranging in composition from syenites to gabbros. The veins occur within these intrusives, vary from 4 to 24 inches in thickness, and are usually but a few hundred feet in length. There are two sets of veins, an older set containing chiefly pyrite and pyrrhotite and striking north and south with dip $45^{\circ} \mathrm{W}$; ; a second and later set striking N. $20^{\circ}$ to $35^{\circ} \mathrm{W}$. and dipping usually $50^{\circ} \mathrm{SW}$., characterized by arsenopyrite, abundant free gold, and occasional particles of tetradymite, which have been incorrectly considered as telluride of gold by the prospectors in this region. These veins are narrow and gold is seldom found in sufficient quantity to encourage extended mining operations.

Wild Cat group.-The Wild Cat claims are located southeast of the Hoadley group and on veins of similar character occurring in a syenite intrusive in the schist formations. The schists strike N. $50^{\circ}$ W. and dip $20^{\circ} \mathrm{SW}$., while the dike trends N. $35^{\circ} \mathrm{W}$. and dips $20^{\circ}$ 
SW. Two sets of veins occur, and, as at the Hoadley group, the pyrrhotite-bearing veins are the older. The developments consist chiefly of open cuts, short tunnels, and shafts. A sample test of 5 tons of ore from one of these veins is reported to have given high values.

Birdseye claim.-The Birdseye claim is located on the shore of Revillagigedo Island 4 miles south of Ketchikan. Although this vein was one of the first to be discovered in the Ketchikan district, little development has been accomplished. Surface stripping and a shaft 32 feet deep constitute the entire improvements. The vein which outcrops on the beach is 3 to 5 feet wide and occurs in a porphyry dike intrusive along the bedding planes in the slate-schist formation, striking N. $30^{\circ}$ to $50^{\circ} \mathrm{W}$. and dipping $45^{\circ} \mathrm{NE}$. This dike, which varies from 10 to 20 feet in width, includes many fragments of black slate, and adjacent to the vein is impregnated with sulphide minerals. The minerals contained in the vein are pyrite, galena, zinc blende, and free gold. In the schist and black-slate country rock, quartz veins were also observed, though these are older than the porphyry dike and do not carry values.

-Laskawonda group.-The Laskawonda property of three claims is located near Ketchikan and is reached by a well-constructed board walk which was to have served as a tramway. The developments consist of a shaft located half a mile from the town at an elevation of 175 feet and reported to be 85 feet deep, a short tunnel, and-surface strippings. The ore body is a slightly mineralized band of the greenstone schist formation, striking $\mathrm{N}$. $50^{\circ} \mathrm{W}$. and dipping $50^{\circ} \mathrm{NE}$., which is cut by a few small quartz veinlets. The metallic minerals contained are pyrite with some chalcopyrite, occurring in the quartz veinlets and in the greenstone schist. For the last few years work has been suspended on this property.

\section{CLEVELAND PENINSULA.}

General description.-Cleveland Peninsula lies between Behm Canal and Ernest Sound and its elongation coincides with the general trend of its constituent mountains. The general geology is comparatively simple; the northeastern part of the peninsula consists of the Coast Range granite, which is flanked on the southwest by the schist belt, which in turn farther south grades into the black slates or argillites. Near the southern end of the peninsula wide belts of greenstone and greenstone schists and occasional limestone beds are intercalated in the slates (see Pl. II).

Masses of intrusive diorite occur within the greenstone-argillite area, and in at least one place have been found to contain ore-bearing quartz veins. Between Helm Bay and Vixen Inlet is a conspicuous red-brown mountain made up of an immense intrusive mass of 
peridotite with serpentine and ferric oxide as weathering products. The strata trend in general northwesterly, with local variations due to folding, and dip northeast at different angles. Near the granite contact, at Spacious Bay and Vixen Inlet, the beds are much folded and are in general flat lying, but to the south the strike becomes more uniform and the dip steeper and in places the dip is to the southwest. Quartz veins are widely distributed throughout the entire formation and have been prospected at only a few points. Prospectors in the region have learned by experience that the veins of value are confined essentially to a wide greenstone schist belt over 1 mile in width and extending from the west side of Helm Bay across the peninsula to Union Bay. The values are variable and, although occasionally high for a short distance, are low in average and must be mined economically in order to be profitable.

Gold Standard group.-The Gold Standard group, belonging to the Alaska Gold Standard Mining Company, embraces 17 claims located on the west side of Helm Bay about $2 \frac{1}{2}$ miles from the head of the bay and one-half mile from tide water (fig. 14). Discoveries at this point were first made in 1897 , and in 1898 the ore from a rich ore shoot near the surface was treated in an arrastre and reported to have yielded about $\$ 20,000$ in value. In 1899 a 5 -stamp water-power mill was installed, several buildings erected, and a tramway built from the mine to the mill and from the mill to the beach one-half mile distant. During 1900 the mill was operated and considerable mining developments accomplished, but at the close of the year work was suspended. In the following years operations on a small scale were advanced, but not until 1906 did active work begin again, when a small shipment of high-grade ore is reported to have been made and a considerable output of bullion was made from the stamp mill. The mine is developed by a shaft starting at a point 225 feet above tide water and 150 feet in depth following the vein, and from this two drifts have been extended developing the ore in depth. Besides these workings short tunnels and several small shafts have been started at other points on this property.

The country rock at this locality is greenstone schist interstratified by argillaceous beds, the general strike being $\mathrm{N} .25^{\circ} \mathrm{W}$. and the dip $60^{\circ} \mathrm{NE}$. Two systems of quartz veins occur in these schists, the older set, which are the larger veins, striking parallel with the schistosity, and the second or younger system following the general trend of the former but dipping $60^{\circ}$ to $70^{\circ} \mathrm{SW}$. and intersecting them in depth. The latter veins are small and often mere gash veins carrying little or no value except at those points where they intersect the veins of the larger system. The principal vein deposit, which is being developed at the shaft, is of the older system, varies from 6 inches to 6 . feet in width and is exposed for over 1,000 feet along its strike. 
154 KETCHIKAN AND WRANGELL MINING DISTRICTS, ALASKA.

The walls of the vein are well defined by slickensides with gouge on the foot-wall side and a seam filled with calcite carrying free gold along the hanging wall. Fault planes transverse to the veins were locally observed displacing the veins from 1 to 3 feet in a horizontal

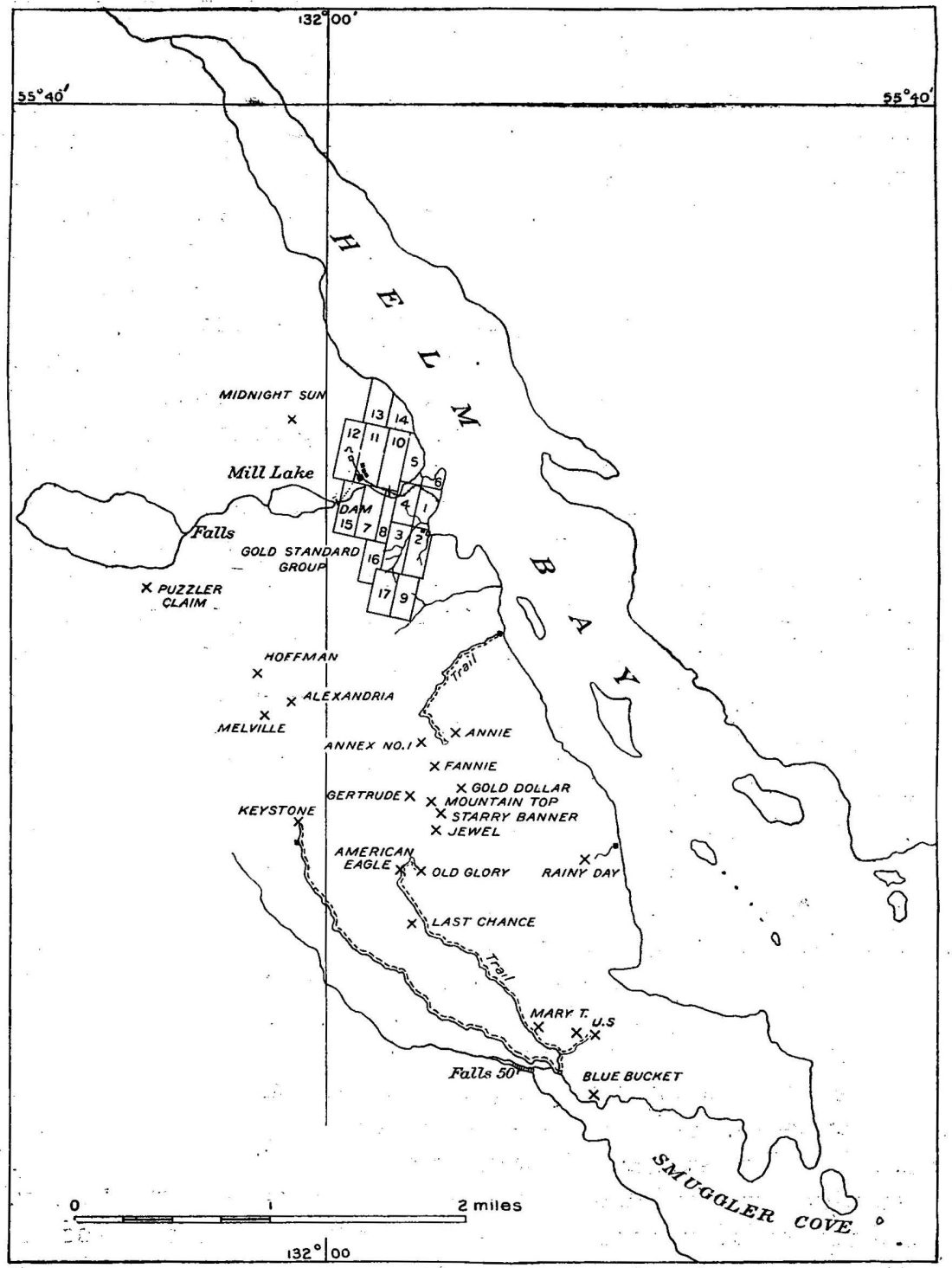

Fig. 14.-Sketch map showing positions of prospects and mining claims at Helm Bay, Cleveland Peninsula.

direction. The ore contained is essentially auriferous quartz with pyrite, and in the gash veins small crystals of tetradymite were noted. The largest percentage of the gold is free milling and can be extracted in the stamp mill by amalgamation. The concentrates, 
which aggregate about 3 per cent of the ore, are saved for smelter shipment and are reported to carry high values.

Puzzler claim.-The Puzzler claim is situated on the south side of a lake 2 miles east of the Alaska Gold Standard and at an elevation of 400 feet (fig. 14). A tunnel 180 feet long has been driven through the greenstone-schist country rock, and at 60 feet from its entrance undercuts a lode deposit inclosed in a graphitic schist. Quartz veins also occur at this place, but are not so strongly developed. The same deposit is exposed by an open cut at 440 feet elevation, the lode being parallel to the schistosity of the country rock which strikes N. $50^{\circ} \mathrm{E}$. and dips $60^{\circ} \mathrm{SE}$. In this deposit two systems of quartz veins occur, which correspond in a general way to those at the Alaska Gold Standard deposit, though they are not so strongly developed, and the ore shoots are smaller. Slipping planes and fault seams are of common occurrence in this vicinity.

Midnight Sun claim.-The Midnight Sun claim lies half a mile west of the Gold Standard mine at an elevation of 560 feet (fig. 14). The vein deposit, which has been exposed by a 15-foot open cut, varies from 6 inches to 2 feet in width, striking N. $80^{\circ} \mathrm{W}$. with a dip $30^{\circ}$ NE. Slipping planes defined by slickensides are of common occurrence across the vein and indicate considerable movement and displacement of both the inclosing greenstone-schists and the vein subsequent to its deposition. Included in the vein are fragments of the schist, the mineral content being pyrite with free-gold particles.

Alexander, Hoffman, and Melville claims.-The Alexander, Hoffman, and Melville claims are situated near the top of the mountain $2 \frac{1}{2}$ miles from the head of Smugglers Cove and $1 \frac{1}{2}$ miles southeast of the Gold Standard mine (fig. 14). The prospects on these properties were located in 1902 and 1903 . The greenstone and slate beds on this mountain are considerably folded and the direction of their strike and dip varies greatly. The vein deposits follow slipping planes transverse to the schistosity of the country rock and are parallel to it. On the Alexander claim a tunnel 45 feet long exposes a vein 6 inches to 3 feet in width striking north and south with dip $45^{\circ} \mathrm{W}$., the footwall side being defined by a gouge seam 1 inch thick. The Hoffman claim includes an irregular vein deposit averaging 5 feet in width, striking N. $5^{\circ}$ W. with a steep dip to the southwest. The inclosing greenstone-schist strikes $\mathrm{N}$. $60^{\circ} \mathrm{W}$. with a dip $70^{\circ} \mathrm{NE}$., and in it are numerous faults showing small displacements. A tunnel 21 feet long has been driven along the vein, and pyrite was observed in it, both in the vein and in the inclosing schist. Fine gold is said to occur, though the average value of the deposit is low. The vein deposit on the Melville claim strikes N. $40^{\circ}$ W., transverse to the trend of the inclosing slate and greenstone, which at this point is $\mathrm{N} .15^{\circ} \mathrm{E}$. It is peculiar because of the occurrence of arsenopyrite both in the 
vein and in the adjacent slates, though where it crosscuts the greenstone this mineral is practically absent. The developments consist of a short tunnel and surface strippings from which a small amount of ore was mined and treated in an arrastre on the property.

Gold Mountain group.-From Smugglers Cove the greenstoneschist belt can be traced along the mountain ridge parallel with the east shore of Helm Bay over Gold Mountain. To the east and west of it black slates predominate. Gold Mountain has a maximum elevation of 2,120 feet, and on it a number of prospects have been located, the principal ones being the Annie, Mountain Top, and Starry Banner. On the Annie claim a 20 -foot shaft was sunk in 1900 on a quartz ore pocket at a point 1,025 feet from tide water, and from this about $\$ 5,000$ is reported to have been derived. At another point a tunnel 450 feet in length has been driven on a lode deposit striking N. $30^{\circ}$ E. parallel with rock structure and from $10 \frac{1}{2}$ to 20 feet wide, in which veinlets from a few inches to a foot in width occur. From the tunnel a shaft 50 feet deep has been sunk and the deposit explored by a drift at this level. Pyrite and chalcopyrite were both observed, but as a whole the lode will average low in values.

On the Mountain Top claim an 8-inch vein striking N. $55^{\circ} \mathrm{W}$. with a dip $25^{\circ}$ NE. crosscuts the greenstone schist formation, which has a northeast trend and a vertical dip. The vein has been exposed by shallow shafts and open cuts, but is too small to be of great value.

On the Starry Banner claim a tunnel 225 feet long at an elevation of 1,950 feet has been driven in a N. $30^{\circ}$ E. direction along an 8-inch quartz vein, which is parallel to the schistosity of the greenstone in trend but intersects it in dip. Along the sides of this vein calcite and epidote veinlets were observed in the country rock and in the vein near the surface the sulphide minerals were considerably oxidized.

Rainy Day claim.-The Rainy Day prospect is located less than half a mile from tide water opposite a small island on the west side of Helm Bay near its entrance. The mineral deposit at this locality is of interest because it occurs in a granite-porphyry dike which is from 600 to 1,000 feet wide and strikes N. $40^{\circ}$ W. The vein deposit, which is $3 \frac{1}{2}$ feet wide, strikes northeast and has been exposed in a 105-foot tunnel at an elevation of 200 feet from tide water. Above the tunnel at 280 feet elevation is an open cut in which the vein is exposed, and at this point are prominent slipping planes striking transverse to the vein. The ore minerals are sphalerite, pyrite, and galena in small amounts, the principal values being in gold, which occurs native in fine particles.

Blue Bucket claim.-The Blue Bucket claim is situated near the northeast head of Smugglers Cove near the beach and has been developed by a short prospecting tunnel. The quartz vein runs irregularly through banded chloritic and sericite schists which strike N. $38^{\circ}$ 
W. and $\operatorname{dip} 65^{\circ} \mathrm{NE}$. Pyrite cubes only were observed in the quartz. The values appeared to be low.

Keystone claim.-The Keystone claim is reached by a trail 2 miles in length which begins near the falls at the head of Smugglers Cove and follows in a northeasterly direction along the eastern valley slopes of Falls Creek. The mine workings are situated at an elevation of about 675 feet and consist of a long crosscut tunnel with drifts, the total length of which is nearly 700 feet. A shaft 65 feet deep has been sunk on the vein. The property has been idle during the last few years and was recently relocated under a new name. The country rock is a green, folded, faulted, chloritic schist striking in a general northwesterly direction with steep vertical dips. The ore body consists of a stockwork of stringer veins occurring in a mineralized belt of schist many feet in width, intensely sheared, and filled with slipping planes. The entire belt is heavily mineralized with pyrite and carries low values in gold and silver. The quartz veins vary in width and usually have free walls often with a coating of mineralized gouge. Calcite frequently accompanies the quartz gangue.

Mary T. and United States claims.-The Mary T. claim and the adjoining United States claim are located near the head of Smugglers Cove and both are practically in an undeveloped state. On the Mary T. claim an open pit exposes the ore body, which is essentially a belt of mineralized and indurated sericite schist. The ore consists of pyrite in well-formed cubes with some chalcopyrite and its weathering products, malachite and azurite. The values are reported to be low. On the United States claim a quartz vein occurs in chlorite schist in irregular lenses often parallel to the cleavage and contains occasional cubes of pyrite. It has been exposed chiefly by surface cuts and short prospect tunnels. The values reported are likewise low.

Last Chance claim.-The Last Chance claim, which has recently been relocated, is situated about 1 mile from Smugglers Cove, and like the preceding claims has not been developed to any extent. The country rock is chloritic schist striking about north and south; the ore body, a quartz vein of irregular width, is contained in a belt of mineralized schist, along which intense movement and shearing has taken place. In the short drift the values in gold are reported to vary and to give a low general average.

Old Glory group.-The Old Glory group of two claims including the Old Glory and American Eagle is situated on the west side of Gold Mountain at an elevation of about 900 feet and $1 \frac{1}{2}$ miles from Smugglers Cove. On the property the ore body has been traced by numerous open cuts and three short tunnels. The ore is treated in a 2-stamp mill, operated by a Pelton wheel. Only the gold which is retained by amalgamation is recovered, the auriferous concentrates being wasted because of lack of proper facilities. The bed rock con- 
sists largely of folded greenstone sehists and argillites striking N. $10^{\circ}$ to $30^{\circ} \mathrm{W}$. The veins are in general parallel to the rock structure, varying from a few inches to a foot in width, and in places the country rock is also impregnated with sulphide minerals, thus forming a lode deposit. Practically no work has been done on these claims during the last few years.

TWEIVEMIUE ARY.

GENERAL DESCRIPTION.

The narrow body of water called Twelvemile Arm extends southwesterly from the head of Kasaan Bay and terminates in a low-lying river valley, over which a long portage is reported to lead to Big Harbor on the west side of Prince of Wales Island. The mineral deposits discovered in this area have been chiefly gold-bearing veins, copper being of only subordinate interest. The most important mines are the Crackerjack and the Puyallup, situated a short distance from. Hollis (fig. 15). In general, mining activity in recent years has been slight and little more than annual assessment work has been accomplished on most of the prospects since the visit of Mr. Brooks in 1901, In the immediate vicinity of Twelvemile Arm and along its shores the country rock consists chiefly of altered argillaceous sedimentary rocks, often schistose, and intruded by extensive granite masses and later porphyry dikes. Belts of greenstone, both massive and schistose, are frequently interstratified with the slates and limestones, but have not yet been found to be mineralized to any extent in this particular area. Directly west of Hollis is a belt of black graphite slates trending about N. $30^{\circ}$ W., which contains the principal vein deposits and which has been traced northwest beyond the Crackerjack mine for several miles to where it is cut off by the granite massif of Granite Mountain. Along this contact, which is well exposed, about 1 mile south of the Granite Mountain claims, evidence of a fault of considerable magnitude can be seen. The granite at the contact sends no apophyses into the invaded slates, indications of contact metamorphism are wanting, and the slate belt near the contact is intensely shattered and bears all signs of extended movement. The slate belt near the Crackerjack mine has been folded into a large anticline, on the southwest flank of which the Crackerjack veins are located, while at the Puyallup mine the beds dip $35^{\circ}$ to $45^{\circ} \mathrm{NE}$. These slates grade to the east into coarser graywackes and altered conglomerates. Farther'south on Twelvemile Arm limestones and calcareous schists are more abundant and trend approximately parallel to the shore with an easterly dip.

The ore deposits in this area are confined chiefly to the black slates soen at the Crackerjack claims and to the Granite Mountain massif, 
The veins are well defined and persistent, usually following intrusive dikes or fracture planes and jointing planes in the country rock. The values are chiefly in gold, with some lead and silver and a little copper. Some of the veins carry locally free gold, but as a general rule the average content is not high.

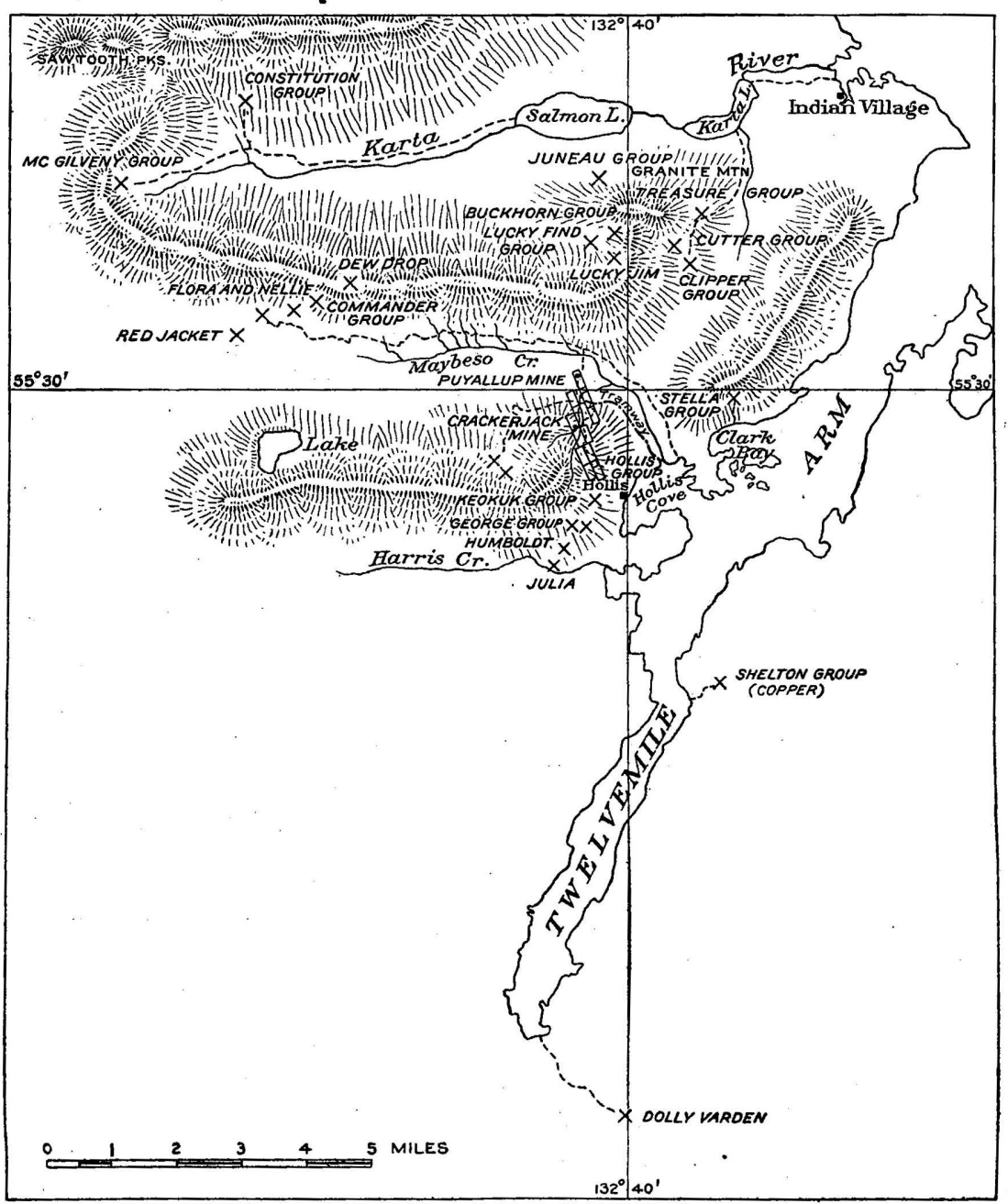

FrG. 15.-Sketch map showing location of claims near Twelvemile Arm, Prince of Wales Island.

PROSPECTS IN THE VICINITY OF HOLLIS.

Puyallup mine.-The Puyallup mine is situated about $1 \frac{1}{4}$ miles from tide water and is connected with Hollis by a tramway, at the end of which is a 5-stamp mill. The group embraces three claims, on which the veins have been traced and developed by several tunnels 
and shafts. The country rock is slate with altered porphyries and clastic breccias, the general trend being $\mathrm{N} .25^{\circ} \mathrm{W}$. and the dip $50^{\circ}$ to $60^{\circ} \mathrm{NE}$. The quartz veins follow planes of weakness and movement along the strike and have been exploited by several tunnels, the long.est measuring 1,135 feet. In the long tunnel two veins are exposed, following the walls of a porphyry dike in the altered slate, the vein along the hanging wall of the dike being richer than the foot-wall vein. Near the face of this tunnel faulting has disturbed the even trend of the vein and added considerably to the difficulties of mining. This pay vein, which averages about 6 inches in width, is exposed in a lower 1,200-foot tunnel for a length of 220 feet and has been traced by outcrops on the surface for about one-fourth of a mile. An upper tunnel, 150 feet above and 900 feet southwest of the main tunnel, has been driven 90 feet on another vein. In this tunnel the vein is considered identical with the pay vein of the long tunnel. The ore is free-milling, 85 per cent of the total value being free gold. The mine has been worked in only a desultory way in recent years, and the production has been small.

Crackerjack mine.-The Crackerjack group of claims is located south and southwest of the Puyallup, with which it is connected by an excellent trail (see Pl. I and fig. 15). Surface improvements consist chiefly of quarters for miners and an ore chute for transporting ore to the Puyallup stamp mill. The Crackerjack vein is an unusually persistent vein and has been followed by surface croppings and test pits along a number of claims. On the Crackerjack claims proper it occurs along the hanging and foot walls of a 16-foot porphyry dike intrusive along the bedding planes of black slate, striking in general N. $25^{\circ} \mathrm{W}$. and dipping $35^{\circ} \mathrm{SW}$. The slate is finely laminated and more or less graphitic. The vein varies in width from a mere seam to 5 feet. Its metallic minerals are pyrite, galena, zincblende, and a black, soft sulphantimony or bismuth mineral, the exact nature of which was not determined; the gangue is essentially quartz with some calcite. The dike itself is characterized chiefly by widespread epidotization and pyrite impregnation. The No. 1 tunnel at 800 feet elevation crosscuts the formation for about 215 feet, at which point the vein is encountered and followed in a southerly direction for about 675 feet. In the crosscut several minor veins were encountered, but were not followed. The gold values in these veins occur in shoots, two of which have been stoped out for 35 and 40 feet above the tunnel level. Occasionally streaks are encountered which give high assay values in silver. The amount of gouge on both sides of the dike is indicative of considerable movement along the fissure planes. Minor transverse slipping planes were also noted, but apparently do not affect the veins materially. In Tunnel No. 2, which is 
400 feet in length, at 1,050 feet elevation, both the dike and the vein were observed to crosscut the formation at one point for about 80 feet and then to resume their normal parallel trend.

Hollis group.-Still farther up the mountain at 1,500 feet elevation a vein similar to the Crackerjack vein has been discovered and explored by a tunnel 400 feet long. The conditions here are analogous to those in the Crackerjack tunnels, including the slate belt, trending and dipping in the same general directions, but the porphyry dike is somewhat wider. The quartz vein was observed to branch out into the porphyry so that for some distance two parallel veins have been followed by the drifts. The walls are well defined and the ore shoots well marked. The black slate belt has been traced still farther south and west over the summit of Hollis Mountain and down into the Harris River valley, where claims have been located on mineralized veins similar in character to the Crackerjack vein. The persistence of these veins is a strong argument for their continuation in depth. The ore production from the entire system of veins has been slight, the work having been devoted chiefly to developing and testing the ore bodies.

Harris River claims.-As stated in the preceding paragraph, the mineral belt on which the claims on the mountain slope north of Harris River are situated is the continuation of the Crackerjack black slate formation. A number of claims, including the Julia, the Humboldt, the George Nos. 1 and 2, and the Keokuk Nos. 1 and 2, have been located in this area and developed to some extent. The general aspect of the mineral deposit on these claims is similar to the Crackerjack deposit. On each claim the developments consist of surface strippings, test pits, and short tunnels. Pyrite, galena, and zinc blende, with occasional free-gold particles, constitute the metallic minerals and quartz and calcite the gangue minerals. Porphyry dikes occur with many of the veins.

Recently considerable work has been done on the Julia claim, the ore shoot of which outcrops in the bed of Harris River. An inclined shaft 200 feet deep has been sunk to undercut this ore shoot, and at the 50-, 100-, and 150-foot levels, drifts have been extended, 35 feet long on the 50-foot level and 80 feet long on the 100 -foot level. The ore shoot is reported to be about 60 feet long and from 2 to 5 feet wide and to carry high values in gold, 50 per cent of which is free milling.

Cascade group.-The Cascade group is located about 2 miles south of the Puyallup mine and at an elevation of 1,300 feet. The developments consist chiefly of two drift tunnels, and in the upper one a quartz vein is well exposed. The vein averages 2 feet in width and fills an old fracture crack in an altered basic intrusive. The lower 40840-Bull. 347-0S-11 
tunnel, which was driven to undercut the vein, is 300 feet in length and crosscuts intrusive rocks and dikes of several different types, but does not expose the vein. The original sedimentary rocks in this area have been profoundly altered by the intrusives, and epidotization is widespread. The vein strikes $\mathrm{N} 53^{\circ} \mathrm{W}$., dips $70^{\circ} \mathrm{SW}$., and has been followed for about 175 feet in the upper tunnel. Its metallic minerals are pyrite, zinc blende, galena, and gold, with quartz and calcite gangue. The values in this vein are very unevenly distributed and the average content is probably not high, although fragments of exceedingly rich ore have been found. Above the Cascade group the Mountain Bell group of three claims has been located on a narrow quartz vein reported to carry good values in free gold.

Dolly Varden claims. - The Dolly Varden group of claims is located in the limestone formation about $1 \frac{1}{2}$ miles southeast of the head of Twelvemile Arm, and at an elevation of 1,100 feet. The marble occurs as a member of the greenstone slate formation exposed along the shores of Twelvemile Arm. The veins are essentially later impregnations along the bedding of the marble strata and strike N. $15^{\circ}$ E. with steep to vertical southeast dip. Gray copper is the essential metallic mineral, and is in many places altered to azurite and malachite. Very little development work has been accomplished on this. group. Several other claims on similar veins and country rock have been located in this area, but were not visited by the writers.

Stella claim.-The Stella claim is situated about one-half mile north of Clark Bay, a small indentation $2 \frac{1}{2}$ miles northeast of Hollis. The quartz vein occurs along the contact of a diorite-porphyrite dike in black slate and has been explored by a tunnel 540 feet in elevation and 130 feet long. It averages 3 feet in width, strikes N. $40^{\circ} \mathrm{W}$. and dips $80^{\circ} \mathrm{NE}$., and is separated from the black slate foot wall by a band of gouge 1 inch thick. The metallic minerals are pyrite, galena, and zinc blende, with quartz and calcite gangue, and occasional included fragments of black slate. The values in precious metals are low.

Flora and Nellie claims.-The Flora and Nellie claims are situated about $8 \frac{1}{2}$ miles by trail northwest of Hollis. The ore body which is being exploited at this point is a quartz vein, averaging with gouge about 4 feet in width and filling an old shearing plane in dioriteporphyrite. Two tunnels have been driven on the vein, a lower one at 1,460 feet elevation and 390 feet in length, and an upper tunnel 90 feet in length; a shaft and winze have also been sunk on the vein. The ouartz vein strikes N. $70^{\circ} \mathrm{E}$., dips $60^{\circ} \mathrm{SE}$., and is heavily min€:alized with pyrite, chalcopyrite, galena, and zinc blende. The lines of movement in the diorite-porphyrite pitch at very low angles, indicating nearly horizontal fault movements. The values from this vein are reported high in gold and silver with some lead and copper. 
At present transportation facilities are a serious problem in the systematic development of the claims in this area.

The southern extension of this group is called the Red Jacket claim, and on its surface stripping only has been done, and that chiefly in glacial drift covering the bed rock. To the northeast the Commander group of two claims has been located on the continuation of the Flora and Nellie vein and outcrops along a steep gulch up the mountain side. On this group two drift tunnels have been driven, the lower one at 1,680 feet elevation and the upper one at 1,825 feet elevation. In these the vein averages about 18 inches in width, with a wide band of soft gouge on the hanging-wall side, and strikes $\mathrm{N} .75^{\circ}$ E., with $\operatorname{dip} 65^{\circ} \mathrm{SE}$. Near the vein the porphyry is altered considerably and often heavily charged with pyrite. The assay returns indicate high gold content with some silver. The metallic minerals are pyrite, chalcopyrite, galena, and zinc blende in quartz gangue.

Rose and Dew Drop claims.-The Rose and Dew Drop claims are located above the Commander group and extend over the ridge for some distance down its north slope. These claims are 2,300 feet above sea level and are located on a vein deposit along a slipping plane in a basic intrusive rock. The vein varies in width from 6 to 14 inches, strikes N. $60^{\circ}$ W., dips $85^{\circ} \mathrm{SW}$., and has been developed by two short drifts. The values are reported to average well in gold and silver.

Constitution group.-On the opposite side of Salmon Lake valley and about 3 to 4 miles north of the Dew Drop claim is located the Constitution group, which is reached most readily by trail from Karta Bay, via Karta and Salmon lakes and up the Salmon Lake valley, a distance of 11 to 12 miles. Here are two tunnels, the lower being at 2,000 feet elevation and 130 feet in length. In this the quartz vein varies from 6 inches to 4 feet in width and trends N. $65^{\circ} \mathrm{W}$. to $\mathrm{N} .45^{\circ} \mathrm{W}$. with a vertical to $60^{\circ} \mathrm{SW}$. dip. It occurs filling a shearing plane in gabbro and amphibolite and is lined frequently on both sides with soft gouge. Vein minerals are pyrite, chalcopyrite, galena, and zinc blende, the surface oxidation of the sulphides being unusually pronounced. In the face of the tunnel a transverse slipping plane appears to have cut off the vein. With present conditions of transportation further development of this group does not seem feasible.

Independent group.-The Independent group of two claims is located several miles west of the Constitution group and at the head of the glacial valley of Salmon Lake. The developments are confined to short tunnels and surface strippings. On the lower claim at 1,300 feet elevation the vein is 1 foot wide, strikes $\mathrm{N}$. $75^{\circ} \mathrm{W}$., dips $75^{\circ} \mathrm{SW}$., has free walls and occurs along a shearing plane in altered porphyry (andesite), which is included in a generally much-altered sedimentary complex. The metallic minerals are galena, pyrite, and 
zinc blende in a quartz and calcite gangue. The vein is reported to give very high assay values in free gold. At the tunnel on the upper claim, at 2,100 feet elevation, the vein is 1 to 2 feet wide, including gouge, and strikes N. $78^{\circ}$ W., dips $75^{\circ} \mathrm{SW}$., and is exposed chiefly along a steep gulch leading down the precipitous mountain slope. The country rock consists of altered slate and graywacke, crosscut by dikes of porphyry. At present these claims are too inaccessible to be of great value.

PROSPECTS ON GRANITE MOUNTAIN.

General description.-The claims on Granite Mountain can be reached most easily by trail from Karta Bay via Karta Lake; a longer and less satisfactory trail leads in a northerly direction from Hollis (fig. 15). Granite Mountain is made up almost entirely of massive granite which is remarkably homogeneous and free from dikes, particularly of the siliceous aplitic varieties. The veins are without exception quartz veins filling well-marked fracture planes in the granite; these planes are sharply marked and remarkably uniform in direction and thickness. The veins are likewise strikingly similar in appearance and mineral content, the quartz being usually stained to a brown-red color. They are characterized by free walls and undoubtedly persist in depth. Frequently the fissures or jointing planes in the granite are filled with diabase dikes which have subsequently been fractured, and in these spaces the mineral-bearing solutions have deposited auriferous veins.

Treasure group.-The Treasure group of twelve or more claims is located on the east side of Granite Mountain about $1 \frac{1}{2}$ miles from Karta Lake. The developments consist of two tunnels, the upper, at 1,380 feet elevation, following the vein for 450 feet. The vein varies from 1 to 2 feet in width and follows the hanging wall of an altered diabase dike rock in the granite. Its general strike is N. $55^{\circ}$ $\mathrm{W}$. and its dip from $60^{\circ}$ to $80^{\circ} \mathrm{NE}$. This vein has been traced up the mountain slope along a steep gulch and over the summit for a mile, five claims being located on this vein alone. At the upper tunnel considerable ore has been extracted and placed ready for transportation. The metallic minerals are free gold, pyrite, galena, and chalcopyrite. The pyrite crystals are frequently coated with a deep-brown lustrous oxidation crust and the chalcopyrite occasionally shows green staining. Movement along the vein is indicated by the soft mineralized gouge, which is frequently found along the vein walls. The country rock, for "which the general term "granite" is used, is a granitoid rock varying in composition from diorite to gabbro and is often strongly epidotized.

The second set of five claims is located on a deposit in a fracture plane, striking $\mathrm{N} 20 \mathrm{E}$. and dipping $20^{\circ} \mathrm{NW}$. This vein crosses 
the first vein about 500 feet above the upper tunnel and likewise is contained in the granite country rock. The width varies from 1 to 3 feet and the values are lower than those contained in the northwest striking veins.

Clipper and Cutter groups.-The Cutter group of two claims and the Clipper group of three claims are located on the east side of Granite Mountain, south of and above the Treasure group. The improvements on these claims consist chiefly of surface strippings and short test tunnels. The veins are similar in appearance to the Treasure veins and strike in general N. $55^{\circ}$ W., with a dip of $60^{\circ}$ NE. They occur in granite or within diabase dikes which intrude the granite. At 2,900 feet elevation the vein on the Clipper group is 8 inches wide and occurs in a diabase dike 20 feet wide, which is much altered and decomposed. At 3,040 feet elevation the vein is 12 to 18 inches wide, but otherwise unchanged in aspect. The Cutter claims, 1,000 feet to the north, are practically identical in all respects and are reported to carry good values in gold.

Buckhorn group.-The Buckhorn group of nine claims is located on the west slopes of Granite Mountain,-near the summit. The vein, which has been exploited by open cuts and by several tunnels, one at 3,100 feet elevation and the second at 3,000 feet, occupies a fissure in the granite, averages about 15 inches in width, and has been traced for several miles, striking N. $5^{\circ} \mathrm{W}$. and dipping $45^{\circ} \mathrm{NE}$. This vein is similar in character to the Treasure vein and is said to carry good values in gold.

Lucky Find group.-The Lucky Find group of four claims is located on a vein deposit striking N. $45^{\circ} \mathrm{W}$. and dipping $60^{\circ} \mathrm{NE}$. In the 50 -foot tunnel at 2,450 feet elevation the vein is 1 foot wide and occurs between a diabase dike and the inclosing granite. The metallic minerals are pyrite and chalcopyrite, with quartz, calcite, and possibly siderite as gangue. Well-defined gouge marks the walls on both sides.

Lucky Jim group.-The claims in the Lucky Jim group are sitıated near the southwest side of the summit of Granite Mountain and are located on a quartz vein striking N. $25^{\circ} \mathrm{W}$. and dipping $40^{\circ} \mathrm{NE}$. and similar in every respect to the other veins of this area. The metallic minerals are altered pyrite, galena, malachite, and azurite.

Other claims.-Other claims on the north side of Granite Mountain, near Salmon Lake, namely the Go-by group and the Juneau group, were not visited by the writers, but are said to be located on veins similar in character to those already described and are reported to carry good values in gold. In this region the question of transportation is necessarily an important factor, and on its solution depends the future of many of these claims. At present profitable 
mining, even in a small way, is almost out of the question owing to the inaccessibility of the region.

\section{CHOLMONDELEX SOUND.}

GENERAI DESCRIPTION.

Cholmondeley Sound is a deep inlet entering the east side of Prince of Wales Island. Ten miles from the entrance it divides into two long arms, the West Arm and the South Arm, each of which is 8 miles in length. On its south side, about 8 miles inside the entrance, is Dora Bay, 3 miles in length and 1 mile wide, forming a good harbor; and 2 miles east of this is Kitkun Bay, which may be entered only at high slack water, its entrance being shallow and obstructed by hidden reefs. Near the entrance to the sound the mountain declivities are gradual and heavily timbered, whereas from both South and West arms the valley slopes rise abruptly to higher altitudes, terminating in peaks 3,000 feet or more in elevation. On few of these does timber grow above the 1,500-foot contour. A low pass 4 miles in length extends from the head of the West Arm to the head of Hetta Inlet, and across this a. Government road has been constructed, so as to form an easy route of travel and means of transportation for light freight from Ketchikan to Sulzer and Coppermount on the west coast of Prince of Wales Island. A second pass 6 miles long extends from South Arm southward to the head of Klakas Inlet. This, however, is used only by the natives. Still a third pass, connecting with a chain of lakes, extends from Dora Bay southeast to the head of North Arm.

The bed-rock geology of this section of the island includes alternating bands of greenstone and sericite schist and limestones, the latter usually altered to marble (Pl. I). These all have a general N. $50^{\circ} \mathrm{W}$. strike with steep dips usually inclined to the northeast. Invading these stratified formations are huge intrusive masses of granite and diorite, which are exposed along the north shore of the sound and form the mountains west of Dora Bay. Dikes of diabase and other porphyritic rocks noted in adjacent areas are also present in this section.

The ore deposits within the area consist principally of auriferous quartz veins, both in the greenstone schist and along lines of brecciation in the limestone, the latter being comparable with those at Dolomi to the southeast, which are described below. Vein deposits rich in galena ore carrying silver values are also being developed.

PROSPECTS SOUTH OF CHOLMONDELEX SOUND.

Gladstone group.-The Gladstone property of four claims lies on the south side of the sound, 3 miles east of the entrance to Kitkun 
Bay, and extends in an easterly direction for a mile from tidewater (fig. 16). These were located in 1904, and considerable prospecting by way of tunnels and open cuts has been done on all the claims, though no extensive developments have yet been undertaken.

The rock exposures on this group of claims consist essentially of limestone, which in places is banded and siliceous and in places schistose, the structural lines striking $\mathrm{N}$. $35^{\circ} \mathrm{W}$. The ore bodies consist of two or more parallel quartz ledges including many fragments of the limestone country rock, and are in general parallel to the bedding planes of the inclosing rock, but in places crosscut them at small angles. The veins vary from 1 foot to 4 feet in width and are exposed at intervals for two claims in length.

On the Gladstone No. 1 claim, 800 feet from and 140 feet above tide water, an open cut and tunnel have been driven on a 3-foot vein for 36 feet, along which an altered diabase dike apparently forms the hang-

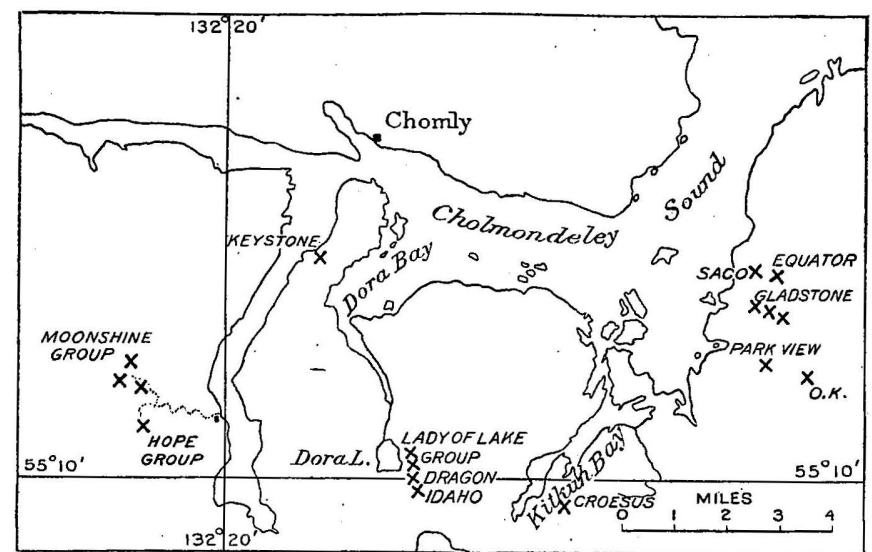

FIG. 16.-Sketch map showing positions of prospects in vicinity of Cholmondeley Sound and Dora Lake.

ing wall. This vein contains pyrite and chalcopyrite in a gangue of quartz calcite and some graphite. One hundred feet south of this a second vein 1 foot to 2 feet wide has been exposed by an open cut at 210 feet elevation. Higher up the hill, at 270 feet elevation and 500 feet east of the tunnel, the vein has a width of 4 feet and shows considerable sulphide ore.

On Gladstone No. 2 claim the general east and west strike of the veins gradually changes to a N. $60^{\circ} \mathrm{W}$., the dip being $85^{\circ} \mathrm{NE}$. At 400 feet elevation an open cut exposes a 6 -foot vein for considerable distance along the strike, and similar showings have been made at various other.points on this and the two adjoining claims extending to the summit of the divide at 850 feet elevation, though it is doubtful if any of these deposits are continuous for so great a length as is generally supposed. 
Equator group.-The Equator group of claims lies one-half mile northeast of the Gladstone group on the south side of Cholmondeley Sound (see fig. 16). This property was located in 1902, but no extensive developments have been accomplished. The principal workings are located at 350 feet elevation, a half mile from tide water, and consist of a 50-foot tunnel along the ore body. The mineral deposit is a quartz vein 3 feet wide, containing masses and fragments of the inclosing limestone country rock, striking N. $60^{\circ} \mathrm{W}$., parallel to the limestone bedding planes, and dipping $50^{\circ} \mathrm{SW}$., cutting the planes at a small angle. Chalcopyrite and pyrite form the sulphide minerals, and the values are essentially in gold. The same vein has been exposed by open cuts at points higher up the hillside.

Saco claim.-The Saco claim, located in 1905, lies just below the Equator claim, at 200 feet elevation, on the southwest side of a gulch. On it a 50-foot tunnel exposes a vein deposit 4 feet in width at its mouth and narrowing to 2 inches at its face. The inclosing rock is a talc schist striking east and west, the trend of the vein being $\mathrm{N}$. $45^{\circ}$ E. with vertical dip. Scattered through the vein are small masses of chalcopyrite and pyrite, carrying small values in gold and silver.

Park View and O.K. claims.-The Park View and O. K. prospects are located on the south side of Cholmondeley Sound, at an elevation of about 900 feet and $1 \frac{1}{2}$ to 2 miles from tide water. The mineral deposits on these claims were discovered in 1905 and have been developed by surface stripping and open cuts. On the Park View claim a 5-foot belt of mineralized schist parallel with the inclosing schists and striking N. $75^{\circ} \mathrm{W}$. has been exposed by an open cut and a pit 8 feet deep. This lode deposit includes stringers and kidneys of quartz and calcite, and chalcopyrite and pyrite are finely disseminated in the veinlets and the schist. The average values are reported to be low, and it is doubtful if ore sufficiently high in grade to mine will be found.

On the O.K. claim, three-fourths of a mile to the west, on the west slope of the ridge, practically no work has been done. The deposit is a well-defined quartz vein striking $\mathrm{N}$. $75^{\circ} \mathrm{W}$. and following the contact between a schist to the north and a limestone belt to the south. The vein is 3 to 4 feet wide and is exposed 100 feet in length, containing chalcopyrite, pyrite, sphalerite, and small amounts of galena, and is reported to carry copper and gold.

PROSPECTS AT KITKUN BAY.

Waslington and Oregon claims.-The Washington and Oregon prospects are situated on the southeast side of Kitkun Bay one-fourth mile from tide water. They were first located in 1900 as the Maggie May group, and in 1904 were relocated under the above names. Most of the development work consists of wide open cuts and 
has been done on the Washington claim near its junction with the Oregon at an elevation of 300 feet (see fig. 17). The ore body consists of a 10-foot band of brecciated limestone and schist, traversed by a network of quartz stringers and veinlets carrying small amounts of sulphide ore. The strike of this lode deposit is N. $45^{\circ}$ E., crosscutting the general trend of the inclosing country rock, which is to the northwest. About 200 feet east of this belt is a vein deposit 3

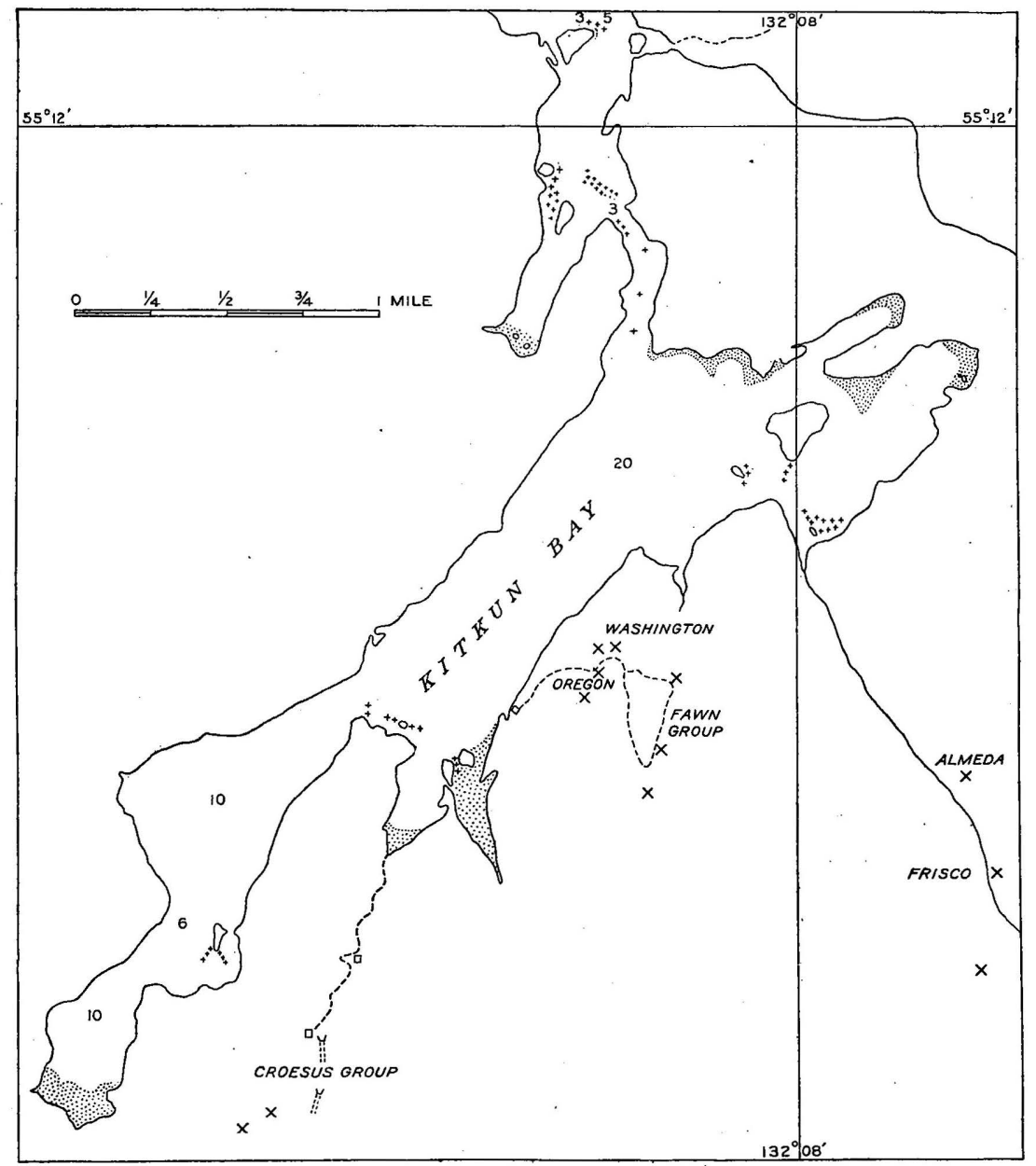

FIG. 17.-Map of Kitkun Bay, showing location of prospects.

feet wide, striking N. $30^{\circ}$ E. with vertical dip and crosscutting the chlorite schist country rock. In this vein pyrite, chalcopyrite, and sphalerite occur, containing small values in gold and silver.

Kid group.-The Kid group of three claims lies one-fourth mile east of the Washington claim. The property was originally located as the Fawn group and is described by Mr. Brooks in his report, but 
since his visit in 1901 little development work has been done, and in 1905 the claims were relocated as the Kid group. Greenstone schists with intercalated limestone beds form the country rock and have a nearly east and west strike with a $\operatorname{dip} 45^{\circ} \mathrm{N}$. Three parallel quartz veins striking $\mathrm{N} .30^{\circ} \mathrm{E}$. with a vertical dip have been prospected on these claims. On claim No. 2 is a tunnel 30 feet long at 650 feet elevation, exposing a vein 4 feet wide, which has been traced for a considerable distance along the surface, following the principal direction of slipping planes and jointing in the country rock. At one point it was crosscut by a diabase dike of more recent intrusion than the ore deposition. The vein is essentially quartz, carrying small amounts of pyrite, chalcopyrite, galena, and sphalerite. About 150 feet east of this tunnel is the second vein, which is from 4 to 8 feet wide and outcrops along the surface for a considerable distance. Where opened by surface cuts, pyrite contained in a gangue of quartz and calcite was the principal sulphide mineral.

The third vein lies 50 feet farther east, and has been explored by several open cuts, exposing a vein 6 feet in width with included fragments of schist in which sulphide minerals. were finely disseminated. This vein, as also the other two, are reported to contain but a few dollars in metal values.

Alameda and Frisco claims.-The Alameda and Frisco claims, which are also undeveloped prospects and represent relocations of the Tom Boy claims Nos. 1 and 2, are situated along a gulch one-half mile from tide water and 1 mile southeast of the Washington claim. On the Alameda claim, at 750 feet elevation, is a vein deposit 4 feet in width striking north and south with a dip of $50^{\circ}$ east, and at 850 feet elevation the same vein is exposed on the east bank of the gulch. The deposit was essentially of quartz, containing very little mineral, and is said to be low in gold value. At 1,000 feet elevation, on the Frisco claim, a 12-foot vein deposit striking north and south has been opened by a surface trench, and in the vein are included fragments of the schist and limestone country rock, and small particles of pyrite. The vein is said to carry but a few dollars in gold values. Above this claim, at 1,050 feet elevation, on the divide between Kitkun Bay and Dolomi or Johnson Inlet, a slightly mineralized lode deposit 30 feet in width is exposed and forms a small ridge protruding above the schist. This is also reported to be of too low grade to mine.

Croesus group.-This group embraces sixteen claims extending 1 mile inland from the south end of Kitkun Bay. They were first located in 1899 and are described by $\mathrm{Mr}$. Brooks, who visited the locality in 1901, at which time energetic developments were being advanced. Since 1902 operations have been suspended. At a point 600 feet in elevation and three-fourths mile from the bay is the Croesus tunnel, 360 feet in length. This follows a quartz vein varying from a 
width of 4 feet at the mouth to 4 inches in width at the face of the tunnel and striking south with a dip of $85^{\circ} \mathrm{E}$. The country rock is a greenstone schist alternating with beds of limestone and striking $\mathrm{N}$. $70^{\circ}$ W. with a dip $70^{\circ} \mathrm{NE}$. Above this tunnel at 750 feet elevation a second tunnel 135 feet long has been driven along the, same quartz vein, though in this the width of the vein was much smaller, varying from 2 to 8 inches. Rich ore is reported to have been taken from this vein, but the pay streaks are small and in places were faulted, thus discouraging further developments. About a half mile southwest of these workings is the San Juan claim, on which at a point 500 feet in elevation a crosscut tunnel 320 feet in length has been driven in a $\mathrm{S}$. $65^{\circ}$ E. direction, and above this a second tunnel 20 feet long has been driven, though in neither tunnel was ore exposed. At 680 feet in elevation a quartz vein 6 feet wide striking N. $20^{\circ}$ W. with a dip $30^{\circ}$ NE. Some high assays have been obtained from the ore in this vein, but its average value is low. Other prospects have been located in this vicinity on similar vein deposits, but these were not visited by the writers.

PRospects AT THE HEAD OF DORA BAY.

General description.-Dora Bay is a narrow inlet 3 miles long on the south side of Cholmondeley Sound (fig. 16). At its head a stream one-half mile long connects with a lake $1 \frac{1}{4}$ miles long, and at the head of the lake the mining prospects are located. These may also be reached by a trail from the head of North Arm. The limestones and schist constitute the principal bed-rock exposures within this area, and on the west side of the bay these are intruded by a wide area of granite, which also forms the west shore of Dora Lake. The mineral deposits are veins in the limestone and schist and contain values principaliy in silver and lead with only small values in goled, the ore minerals being galena, sphalerite, pyrite, and chalcopyrite.

Lady of the Lake group.-The Lady of the Lake claims, three in all, are located just above the southwest end of Dora Lake $1 \frac{3}{4}$ miles from the bay. At 220 feet elevation a crosscut tunnel 68 feet long undercuts a vein deposit 3 to 8 feet wide along a plane of brecciation in the calcite-schist country rock. At its outcrop 60 feet above the tunnel the vein has been opened by surface trenches along its strike, which is $\mathrm{N} .10^{\circ} \mathrm{W}$. with a dip $50^{\circ}$.SW., parallel to the bedding planes of the inclosing limestone country rock. The contained minerals are galena and sphalerite, with some pyrite and chalcopyrite, and the values contained are in gold and silver. No work has been done during the last few years on this property.

Oregon and Idaho claims.-The Oregon and Idaho prospects were originally located as the Frisco group in 1899, and in 1903 were relo- 
cated under the above names. They are situated just south of the Lady of the Lake group and half a mile from the western end of Mineral Lake, tributary to North Arm. The rock exposures consist of decomposed and slightly mineralized schist striking N. $20^{\circ}$ W. and dipping $70^{\circ} \mathrm{SW}$. The ore body is a well-defined vein deposit 3 feet in width striking N. $20^{\circ}$ E. with a dip $70^{\circ}$ SE., and follows the 150 foot contour of the mountain slope for several hundred feet. It has been developed by pits and open cuts and contains sphalerite, pyrite with some galena, and chalcopyrite. The ore body is not large and the values are said to average but a few dollars.

Doromi.

General description.-Dolomi is a small mining town at the head of a small bay on the north side of Johnson Inlet, which has its entrance south of Cholmondeley Sound. Tributary to this bay are two broad, low-lying valleys occupied by lakes, the one trending to the north and the other to the west. The surrounding mountains are relatively low, with gradual slopes densely wooded to their summits.

The rock exposures are the continuation of the limestone and schist belts exposed in Cholmondeley Sound to the north and having an east and west strike (see PI. I). The rock beds at this point are closely folded, and the limestones are altered to marble, which is often banded blue in color and siliceous. The schists are made up principally of greenstone material, chiefly indurated tuffs, and interbedded with them are sericite and argillite schists. Numerous dikes of diabase intrude these rock beds as well as the ore deposits.

The ore bodies are typical examples of the breccia veins and usually strike parallel to the general structural planes of the altered limestone and siliceous schist country rock. Along these planes the mineral solutions have circulated, depositing quartz and various metállic sulphide minerals, which together form the cementing material of the brecciated limestone fragments. These included rock fragments, as well as the inclosing wall rock, are largely replaced by the ore-bearing minerals. These deposits vary from 2 to 10 feet in width and are often traceable for 1,000 feet or more. The minerals contained are fine gold, tetrahedrite, galena, sphalerite, chalcopyrite, and pyrite, with quartz and calcite as gangue. At the surface exposures the tetrahedrite and chalcopyrite are in some instances altered to malachite and azurite, which tinge the veins with characteristic green and blue colors. In this type of deposit the richer ore generally occurs in the form of shoots within the vein, pitching at an angle to its dip. Of the many veins that have been prospected, the Valparaiso, Paul, Amazon, and Golden Fleece are best known. Since 1898 prospecting has been done in this vicinity, and a vast number of claims have been lo- 
cated and partially developed, but only those properties on which the larger ore bodies have been exploited will be described in the following pages. From two mines, the Valparaiso and Golden Fleece, a small production of high-grade ore was made in former years, but of late mining progress has been retarded by litigation. But this difficulty is said to have recently been overcome.

Valparaiso group.-The Valparaiso group of claims includes several locations along the north side of Paul Lake, from 1 to 2 miles from Dolomi, and are connected with the head of the bay by a surface tramway (fig. 18). The principal development work has been advanced on the Valparaiso claims Nos. 1 and 2, and on the Paul and

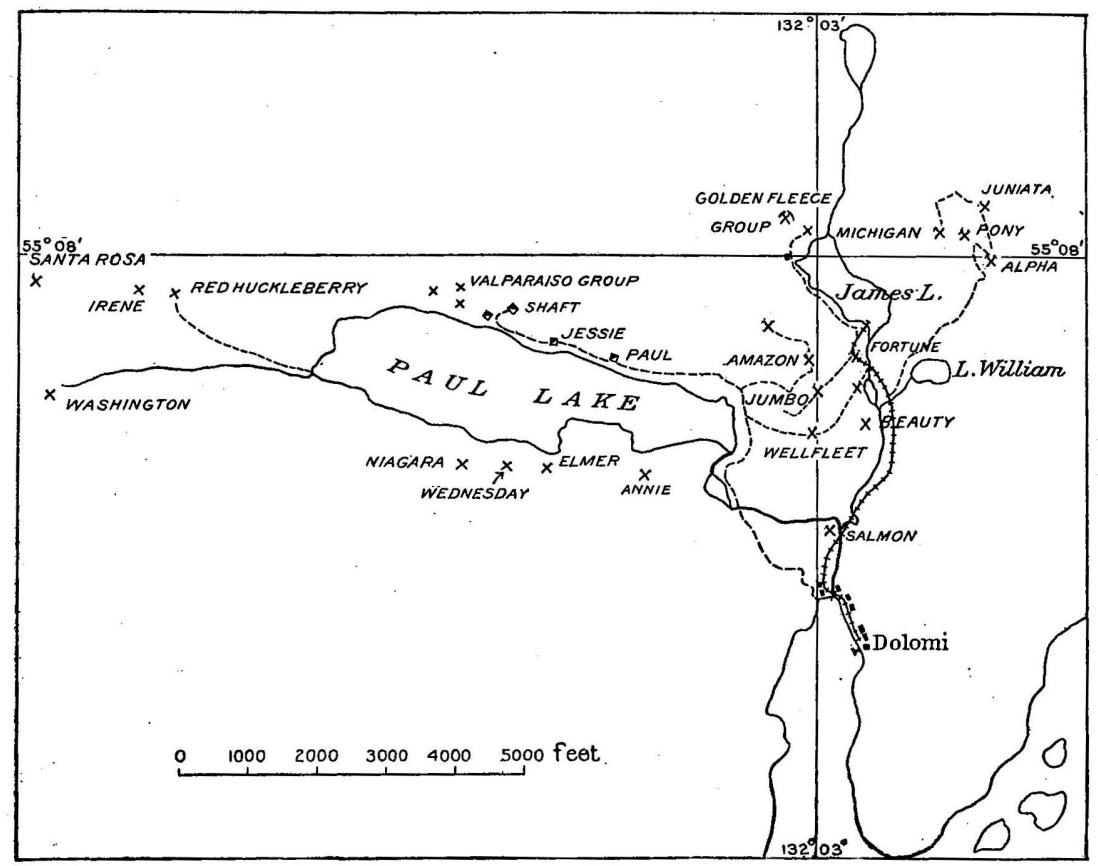

FIG. 18.- Sketch map showing mines and prospects near Dolomi, Prince of Wales Island.

Jessie claims. The Valparaiso claims are located from 80 to 100 feet above and one-fourth mile from the northwest end of Paul Lake; the workings consist of two shafts 150 and 225 feet in depth, from the latter of which 90,150 , and 200 foot levels have been extended along the vein 175,350 , and 250 feet, respectively, in length. On the Paul and Jessie claims, along the north shore of Paul Lake, several shafts have been sunk from 10 to 60 feet, following the veins, and various cuts expose the ore body along the surface. The Valparaiso vein is probably the largest and most extensive of the ore bodies that have been discovered in this section. It has been traced several thousand feet and a verages from 4 to 10 feet in width. It has a N: $55^{\circ} \mathrm{W}$. 
trend and dips $30^{\circ}$ to $50^{\circ} \mathrm{NE}$, the variation being due to the folding and flexing of the inclosing limestone beds, with which the vein is in general parallel. Taken as a whole, the vein is of moderate grade ore, but several ore shoots containing high values have been found in it, and from the main shaft on claim No. 1 a considerable amount of this ore has been mined. The following figure presents a cross section and plan of the ore shoot in this vein as exposed at these workings (fig. 19). The ore shoot is confined to the foot wall, and pitches $60^{\circ} \mathrm{SE}$. The central portion of the vein is made up of limestone breccia in a quartz matrix, and on both the foot and hanging wall sides it is defined by veins of massive quartz. Slipping planes along which gouge matter is present were observed striking parallel with the vein. The ore minerals are tetrahedrite carrying free gold, chalcopyrite, and some pyrite.

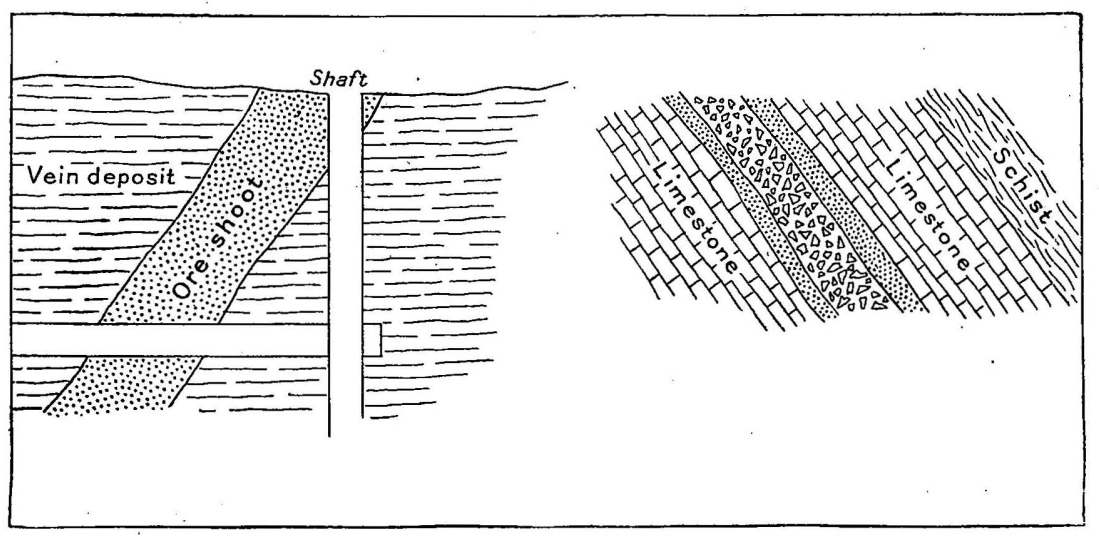

FIG. 19.-Sketch of mine workings at Valparaiso mine. Dolomi, showing position of ore shoot.

The veins exposed on the Paul and Jessie claims are similar to the Valparaiso vein and have fairly well-defined walls. The principal vein, which has been developed on both of the claims, strikes N. $70^{\circ}$ W. and dips $35^{\circ} \mathrm{NE}$. It varies from 3 to 8 feet in width and follows the general trend of the inclosing limestone. It is traversed by slipping planes, showing that a deformation of the vein has taken place since its deposition. Both in the vein and in the country rock sulphide minerals are finely disseminated and occur in small masses throughout the vein. The minerals observed are free gold, pyrite, chalcopyrite, tetrahedrite, galena, and sphalerite, and at the surface malachite, azurite, and limonite are present.

Amazon claim.-The Amazon claim is located about 1 mile north of Dolomi and west of John Creek (fig. 18). The country rock is a calc schist striking N. $85^{\circ}$ E. with a dip of $50^{\circ} \mathrm{NW}$. The deposit is a breccia vein from 5 to 10 feet in width, which is parallel to the 
bedding plane. The developments consist of an inclined shaft 125 feet deep and at a point 50 feet below the surface a drift extended 30 feet to each side. The ore is of relatively low grade.

Salmon claim.-This claim is located on the west side of John Creek one-fourth mile north of Dolomi (fig. 18). The ore at this point is inclosed in a greenstone schist and consists of a breccia vein averaging 5 to 15 feet in width, striking $\mathrm{N}$. $80^{\circ} \mathrm{W}$. and exposed for 300 feet in length by open cuts and shallow pits. The surface exposures of this deposit are much oxidized, the original sulphide minerals being pyrite and chalcopyrite. Material from the oxidized portion subjected to pan tests yielded colors of gold.

Beauty claims.-The Beauty group of two claims lies one-half mile north of Dolomi on the east side of John Creek, the lower claim crossing to the west side of the creek (see fig. 18). A quartz vein 4 to 6 feet wide striking N. $20^{\circ}$ E. and dipping $45^{\circ}$ SE. constitutes the ore body. This traverses a limestone belt striking $\mathrm{N} .30^{\circ} \mathrm{W}$. and has been traced for nearly 1,000 feet, being exposed on claim No. 2 by two inclined shafts 50 feet and 60 feet in depth and on claim No. 1 by a 15 -foot shaft. On the east side of the latter claim another vein deposit 2 feet in width parallels the bedding plane of the limestone, but has only been exposed by an open cut. The minerals contained are tetrahedrite, chalcopyrite, and pyrite, with small amounts of malachite and azurite exposed on the surface.

Fortune claims.-The Fortune claims begin 100 yards below the mouth of James Lake and extend northwest along the southwest shore of the lake. The country rock is a graphitic schist with included bands of blue limestone. The ore body is a lode deposit striking $\mathbf{N}$. $60^{\circ} \mathrm{W}$. and dipping $25^{\circ} \mathrm{SE}$. and is 10 feet or more in width including quartz veins from 1 foot to 2 feet in width. Slipping planes are of common occurrence throughout the deposit, and in places it is much fractured. Chalcopyrite and pyrite are the principal minerals that occur. The developments consist of shallow shafts and open cuts and do not exceed in amount the annual assessment requirements.

Alpha group.-The Alpha claims, three in number, are located between 300 and 400 feet elevation on the mountain $1 \frac{1}{2}$ miles from Dolomi and half a mile east of James Lake (see fig. 18). The principal ore body developed consists of a vein deposit 5 feet in width, which has been traced for nearly 2,000 feet in length. The rock formation consists of a banded limestone, in places schistose and much folded, striking N. $80^{\circ} \mathrm{W}$. The vein has a north and south strike and dips $45^{\circ} \mathrm{W}$. and contains pyrite and chalcopyrite with small values in gold. The development work consists of open cuts and a shaft 35 feet deep.

Golden Fleece group.-The Golden Fleece property, which represents one of the earliest locations in the region, lies on the north end 
of James Lake 2 miles from tide water (see fig. 18). A 5-stamp mill was erected on the property in 1901 and a tramway built from the lower end of the lake to the wharf at Dolomi. The mine developments, which were actively advanced in 1901-2, consist of two long tunnels, each 200 feet in length, and from them stopes and winzes have been sunk on the ore body. Early in 1905 work on this property was suspended and since that time no attempt has been made to operate this mine.

The ore deposits are irregular lenses slightly cutting the bedding planes of the inclosing limestone and varying from a fraction of a foot to 8 feet or more in width. The strike of these irregular deposits is northeasterly, the dip being $40^{\circ} \mathrm{SE}$. A peculiar and advantageous feature of this mine is the occurrence of several limestone caverns which in places follow the mineral deposit. Crosscutting both the limestone and the ore bodies are diabase dikes which are of more recent intrusion than the ore deposit. The ore consists of free gold with tetrahedrite and pyrite, the grade on a whole being moderate.

\section{PROSPECTS ON SOUTH SIDE OF NORTH ARM.}

On the south side of North Arm several groups of claims have been located on the mountain slope 1 to 2 miles from the shore, but with the exception of annual assessment work the developments have been slight (see fig. 7).

The Westlake group consists of three claims, the Little Annis, the Blue Bird, and the Homestakè, located in 1901. On the Little Annis claim, at 1,200 feet elevation, quartz stringer veins occur in granite near its contact with a schist belt and have been exposed near its contact by several open cuts. The veins strike N. $30^{\circ}$ E. and dip $70^{\circ}$ SE.; they are variable in width, contain pyrite in small amounts, and are reported to carry low values in gold. At 1,500 feet elevation, on the Blue Bird claim, which has been relocated and is now called the Sleepy Eye claim, a shaft 40 feet deep has been sunk on a bedded vein in mineralized schist, striking N. $60^{\circ} \mathrm{W}$. and dipping $55^{\circ} \mathrm{SW}$. The metallic minerals are galena, zinc blende, pyrite, and occasional particles of free gold, in a gangue of quartz and graphite. The schist formation is banded and varies from phyllite to green chlorite schist. The vein is reported to carry high values in gold and can be traced for a considerable distance. The main quartz vein shows evidence of having been fractured and recemented by later quartz fillings. The developments on this group of claims, however, have not yet progressed sufficiently to expose ore bodies of any extent or great promise.

Northwest of the Westlake group and nearer the shore is the Hope claim, on which a pyritiferous quartz vein has been discovered fol- 
lowing slipping planes in chlorite schist. The vein is irregular in width and direction and has been. investigated by means of a tunnel at 450 feet elevation and about 80 feet in length. Not far from thetunnel a large intrusive granite mass invades the chlorite schist. These claims were visited and described by Mr. Brooks in 1901, and but little work has been accomplished on them since that time.

GRAVINA ISLAND.

GENERAL DESCRIPTION.

The only gold deposits so far discovered on Gravina Island are along its eastern shore opposite Pennock Island. This portion is made up of the greenstone schists with interstratified slate beds striking N. $50^{\circ} \mathrm{W}$. and dipping $60^{\circ} \mathrm{NE}$. These are intruded by occasional dikes of diabase striking approximately north and south, which crosscut the ore deposits. The ore bodies are both vein deposits and lode deposits, the latter being the most important. 'The lodes consist of an impregnation of sulphide minerals and fillings of quartz in the form of veinlets along beds of altered greenstone schist. This character of mineralization extends from 5 to 50 feet in width and is often traceable for a few thousand feet along the trend of the schist. Such lodes may be readily recognized on the surface by the bleached appearance of the rocks caused in part by the decomposition of the sulphide minerals. The principal metallic mineral is pyrite, disseminated in the form of small, bright cubes and contained in both the quartz veinlets and the schist in amounts varying from 2 to 4 per cent. The presence of slipping planes and narrow seams, usually transverse to the schistosity, which are often filled with quartz containing the sulphide minerals galena and sphalerite, indicates an injection of mineralizing solutions subsequent to the main period of ore deposition. Gold is also present in these later veins in small visible particles.

GOLDSTREAM GROUP.

Situation and development.--The Goldstream group of six claims, the property of the Irving Consolidated Mining Company, is situated close to tide water on the east side of Gravina Island 3 miles south of Ketchikan. The presence of mineral deposits outcropping along the shore at this locality has been known since 1897, and various attempts have been made to develop them, but with little success. The principal work was done in 1903, when a 5-stamp mill was installed, a shaft was sunk, and drifts were extended along the ore body. Small developments were accomplished the following two years, and the values recovered from the ore mined and treated in the stamp mill are reported to have defrayed all development expanses. In 1906 
the Irving Consolidated Mining Company was organized and larger operations were begun. The present developments consist of a shaft 115 feet in depth, from which two levels 50 and 100 feet below the surface have been extended and about 400 feet of drifting and crosscutting has been accomplished. From the stopes in the ore body 3,000 tons of ore are reported to have been mined. At other points on each of the two adjoining claims to the southeast belonging to the same company a 50-foot shaft has been sunk and open cuts and trenches have been made along the ore bodies. Besides the 5-stamp mill a wharf has been built and several buildings erected.

Ore bodies.-Two lode deposits occur at this mine, both striking parallel with the schistosity of the inclosing rock and being separated by a belt of unmineralized schist 90 feet in width. The country rock is a schist of variable character, made up of both igneous and sedimentary material, the predominant varieties being chlorite, talc, and quartz-sericite schist. The main deposit, on which the principal developments have been advanced, has a width of 4 to 8 feet and is traceable 1,000 feet or more in length. Though the lodes are mineralized throughout, the values are confined to an ore shoot pitching $60^{\circ}$ SE. in the lode exposed at the top of the shaft. This is exposed in both the 50- and 100-foot levels for 60 to 80 feet in length, and from it a large portion of the ore has been mined. It is reported that late in 1906 another ore shoot had been opened on the 100-foot level by a drift extending northwest from the shaft. The principal minerals contained in the ore from this deposit are pyrite, chalcopyrite, galena, sphalerite, and some arsenopyrite. The gold occurs native, associated with the sulphides and quartz seams in small particles, and along slipping planes and cracks in the form of thin flakes. In the mine workings an altered diabase dike several feet wide has been encountered crosscutting the ore body and striking N. $10^{\circ} \mathrm{W}$. with a dip of $75^{\circ} \mathrm{NE}$. Quartz stringers barren of mineral were observed to intersect this dike, and these and the dike are younger than the general mineralization of the schists and apparently of more recent intrusion than the second period of mineralization represented by the quartz seams carrying galena and sphalerite. On the second lode deposit, 100 feet southwest, is a much wider ore body exposed across a width of 40 feet and for several hundred feet in length. The hanging- and foot-wall sides of this lode are defined by bands of heavily mineralized rock 8 to 14 feet wide, the central portion being composed of but slightly mineralized schist. A 50-foot shaft has been sunk on the foot-wall portion of the lode, but the ore developed carries only small values in gold. The possible continuation of this deposit has also been prospected on the adjoining claim to the southeast by a 50 -foot shaft and surface trenches. 
HECKMAN GROUP.

The Heckman group consists of five claims which start at a point on the shore 1 mile south of the Goldstream mine and extend northwesterly up the eastern slope of the island. Close to the beach is a 60 -foot shaft with drifts 32 feet in length exposing a lode deposit 8 feet in width. At a point half a mile to the northwest a second shaft has been sunk 50 feet on a similar lode deposit, though at this point but a small amount of mineralization was observed. No work has been done on these claims during the last few years.

MOONSHINE GROUP.

The two claims which comprise the Moonshine group are located one-fourth mile south of the Heckman group. The ore bodies on these claims consist of two parallel vein deposits striking northwest, the one 18 feet and the other 6 feet wide, separated by 50 feet. The country rock is made up of black and altered greenstone schist. On the larger vein is an open cut 30 feet long, and on the smaller vein a shaft 12 feet deep has been sunk. No work has been advanced on these deposits during the last few years and the ore is apparently of too low a grade to encourage further developments.

\section{ANNETTE ISLANB.}

Annette Island lies just south of Gravina Island and includes an area of 133 square miles. The eastern and central parts of the island are abrupt and mountainous, the highest summit being Mount Tongass, with an elevation of 3,684 feet; the west coast of the island is low and flat and is fringed by dangerous reefs. The only. village on the island is the thriving Indian settlement Metlakatla, which is unique in many ways and owes its existence and present prosperity entirely to Mr. William Duncan, whose active life has all been practically devoted to the uplifting and education of this tribe of Indians. The results he has attained and the high plane of civilization to which he has brought these untaught Indians are most creditable, and, as an example of devotion and self-sacrifice, his work will ever remain an unparalleled achievement in the annals of the pioneer life of Alaska.

By act of Congress Annette Island was reserved for the exclusive use of the Indians under Mr. Duncan. At the time when this act was passed little was known of the mineral resources of this country, although prospectors had already located claims on the east side of this island and developed them to some extent. On the passage of this law these prospectors were banished from the island and further prospecting prohibited, the object in view being to isolate the Indians and remove them from the influence of the whites as much as possible. In the course of years the Indians have shown themselves independent and capable to cope with the white men in their chosen 
field of activity. With the exception of Metlakatla, the island is uninhabited and is benefiting neither Indian nor white man. In his report on this district Mr. Brooks ${ }^{a}$ presented a broad view of the case and suggested that the eastern mountainous half of the island be opened to prospectors and mining men, to whom much of the development of this region is due. The Indians by nature do not take kindly to prospecting and mining and have given no indication that they will ever use in any way the eastern half of the island, which has little or no value from an agricultural standpoint. To release the land a special act of Congress will be necessary, and even then it is not certain that mineral deposits of great value will be discovered. However, abundant evidence of mineralization and small deposits of high-grade ore were observed on the island by the writers.

The geology of the island is represented in a general way on the map (Pl. II). The central portion is composed of intrusive granitic masses and is surrounded by Paleozoic limestones, schists, and slates, and along the eastern shore the latter are overlain by greenstones with interstratified slate beds. Along the southeastern shore, both in the granite and the schists, are vein deposits in which pyrite, chalcopyrite, and some galena were noted. Many of these were located and prospected in former years. Vein deposits and ore pockets occurring in a limestone belt were developed to considerable extent at a point 2 miles from tide water on the south side of a lake on the east side of the island. These veins are small and of no great extent, being less than a foot in width and less than 100 feet in length. Several of these deposits, some of which are mere pockets, have been exposed by open cuts. They contain much tetrahedrite and some chalcopyrite, and are said to carry high values in both gold and silver. On the east side of this lake is a band of mineralized schist containing chalcopyrite and pyrite, which, however, has not been developed and is said to carry low values in copper and gold.

North of these deposits, about a mile from tide water, quartz veins were observed in the schist adjacent to the granite and in a few instances in the granite. These are well defined on the surface and vary from 1 foot to 4 feet in width. They contain practically no sulphide minerals, and are said to carry low values in gold.

Mining developments and prospecting have been at a standstill since this island was made an Indian reservation, and the above prospects and deposits, though worthy of further investigation, have been idle.

\section{DALL ISLAND.}

General description.-Dall Island is an irregular mountainous land strip, about $40^{\circ}$ miles in length, lying southwest of Prince of Wales Island, with summits averaging from 1,500 to 3,000 feet in altitude.

a Broeks, A. H., Prof. Paper U. S. Geol. Survey No. 1, 1902, pp. 108-109. 
It is made up essentially of schist, limestone, and occasional narrow belts of granite, all of which have a northwesterly trend and traverse the island at an angle to its principal axis. Prospecting has not been vigorous in consequence of its isolated position, and its oceanward coast is known to only a few of the more persistent gold seekers.

Dakoo Harbor prospects. - The principal prospects on Dall Island are located at the south end at Dakoo Harbor, 2 miles northeast of Cape Muzon, on the Elk and Virginia claims. The ore bodies are both auriferous quartz veins and belts of schist impregnated with gold-bearing sulphides. On the Elk group, which is situated only a short distance from tide water, two tunnels have been driven 200 and 265 feet in length, at 80 and 450 feet elevation, respectively. The deposit is exposed only in the upper tunnel and by several open cuts. It consists of a belt of decomposed schist, and across a width of 50 feet or more this is reported to carry sufficient values in gold to make low-grade ore. The Virginia group lies northwest of the Elk at an altitude of 300 feet, $1 \frac{1}{2}$ miles from tide water. Bands of mineralized schist also occur on this property, but the principal ore bodies are quartz veins varying from narrow stringers to veins 10 feet in width. They are exposed by two shafts less than 20 feet in depth and by short tunnels located in a narrow creek canyon. The country rock is a weathered amphibole schist interbedded with narrow bands of crystalline limestone. The gold values are associated with pyrite, chalcopyrite, and galena, and are said to be higher than those contained in the Elk lode.

Mount Vesta prospects.-The Mount Vesta group of claims, a property of the Alaska Industrial Company, is located on the northeastern slope of Mount Vesta, about a mile from Mount Vesta Harbor. The mineral occurs in small seams or veinlets a few inches in width and separated by wide areas of crystalline limestone. The ore is of high grade and composed essentially of tetrahedrite (gray copper) and chalcopyrite with galena and sphalerite. The mine workings are situated between 600 and 800 feet in elevation, and consist of open cuts and a tunnel 80 feet in length. Many other prospects have been located along the east coast of Dall Island, though no improvements of importance have been made on them.

\section{BAKER ISLAND.}

Baker Island is one of the smaller seaward mountainous land masses off the west coast of Prince of Wales Island and north of Dall Island (see Pl. I). Its western side is composed of a granite belt intruding argillaceous schists, which lie to the east, striking northwesterly and dipping northeast. The rock exposures around the east side of the island are mainly of greenstone lava and tuff beds with some interstratified argillites. 
Adjacent to Port Antonio, in the central portion of the island, deposits consisting of small quartz veinlets in the granite and the adjacent schists have been located and prospected to some extent.

The principal prospect is located on the north side of the bay at about 300 feet elevation. Here quartz veinlets carrying some galena, sphalerite, and pyrite inclosed in the argillaceous schists have been exposed by open cuts, and the ore is said to carry high values, though the amount developed is small. Near the entrance to San Antonio Bay several parallel quartz veins are exposed along the shore inclosed in the granite and containing small amounts of pyrite. They have not been developed, and the values contained are said to be low.

\section{WOEWODSKI ISLANI.}

General description.-Woewodski Island lies between the south end of Wrangell Narrows and the entrace to Duncan Canal and is separated from Kupreanof Island to the north by Beecher Pass. It is a relatively low-lying land mass from 3 to 4 miles in width and $5 \frac{1}{2}$ miles in length, and is heavily timbered to the mountain tops. Geologically the island is traversed by the slate-greenstone belt striking northwest and intruded by diorite batholiths in a small area in the northeast section of the island. A large number of mining claims are located along both the east and west shores of the island and a large amount of development work has been done, though none of the properties have reached the producing stage. The ore bodies are principally vein deposits containing essentially gold values and inclosed in the slate greenstone country rock.

Hattie group.-The Hattie group of claims, the property of the Olympic Mining Company, is situated close to tide water on the southwest side of Woewodski Island (see fig. 20). The claims were first located in 1900, and in 1901 active developments began and progressed until the end of 1903 . In 1904 operations were suspended and the property was idle until the summer of 1907 , when small developments were again in progress. The surface developments consist of a wharf, connected by a tramway 1,000 feet long with the mine workings, and various mine buildings.

At the mine a 360 -foot tunnel has been driven in a northeasterly direction, and at a point 60 feet from its mouth a shaft has been sunk 135 feet in depth from the tunnel level, and from this shaft two levels have been extended at depths of 62 and 134 feet. At the time of the writer's visit the shaft was filled with water, and observations were necessarily confined to the tunnel and surface exposures of the ore bodies.

. The country rock is essentially an altered greenstone, in places schistose, striking northwest. The ore bodies are vein deposits filling fissures and breccia veins along planes of brecciation in the country 
rock, and in places both fissure and breccia veins occur together. Several deposits of this character have been exposed in the mine workings and along the surface, the largest being the Hattie vein, varying from 5 to 20 feet in width, and traceable for several hundred feet in length. The vein has a northeast strike and dips $80^{\circ}$ SE., but in places it stands nearly vertical. As a whole it is apparently of too low grade to make ore, but in it are shoots of ore pitch-

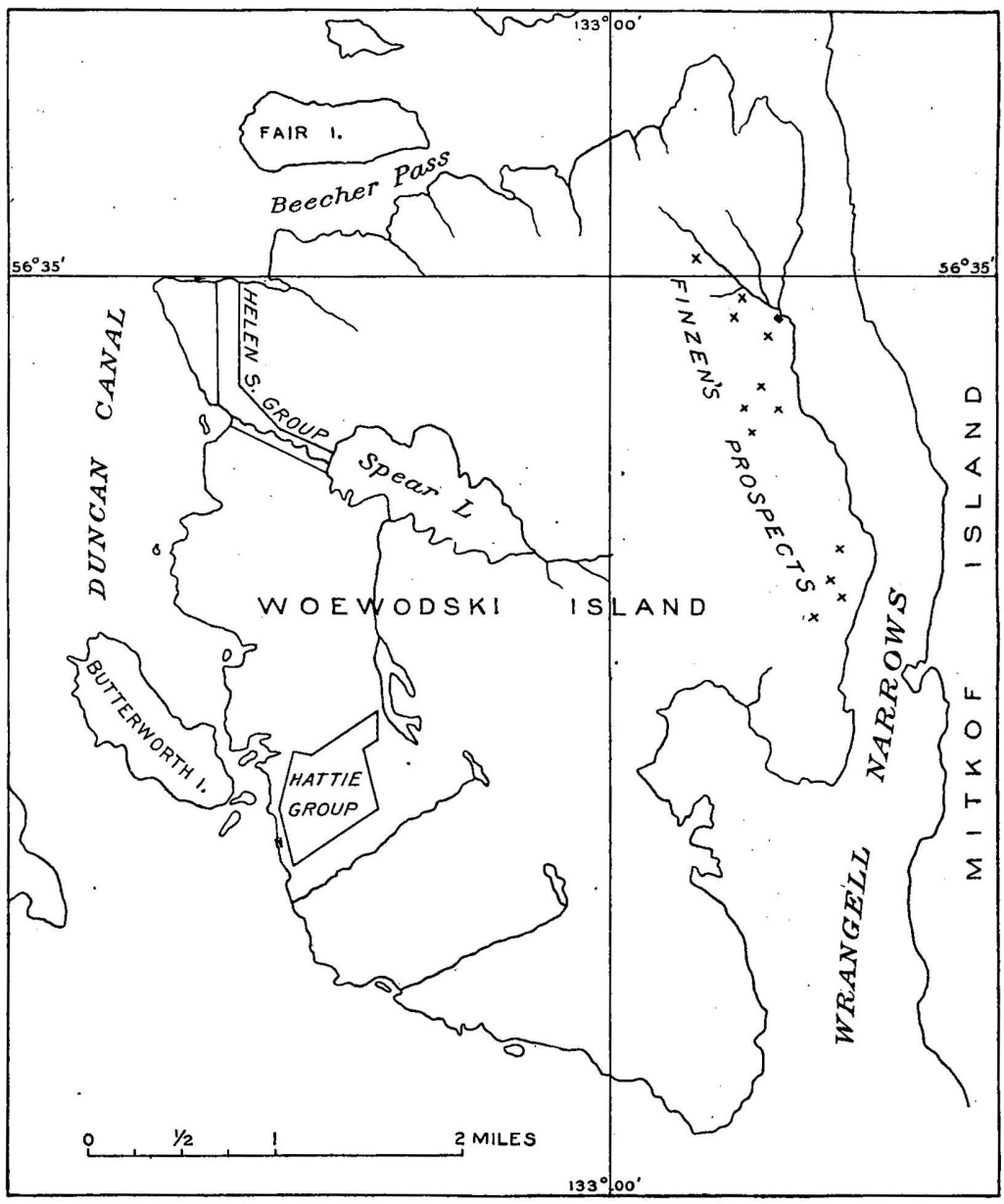

FIG. 20.-Sketch map of Woewodski Island, showing positions of mining claims.

ing southwest in which good values are reported. Fault planes, indicated by gangue seams, were observed striking north and south, but they do not appear to have displaced the vein to any extent. The vein material is principally quartz surrounding large masses of altered greenstone, which is also slightly mineralized. The ore minerals, which constitute from 1 to 3 per cent of the vein filling, are 
pyrite, with chalcopyrite, galena, and some sphalerite. The values contained are essentially in gold, with some silver and copper.

Helen S. group.-The claims belonging to the Helen S. group are situated $2 \frac{1}{4}$ miles northwest of the Hattie group on the northwest end of the island. The claims were located by the Olympic Mining Company in 1902, and active developments were advanced in 1903 and to some extent in 1904. In 1905 and 1906 the property was idle, and not until the summer of 1907 was it reported that small developments had again begun. A 20-stamp mill and compressor plant have been erected on the property, but, except a small run for test purposes, this machinery has remained idle. At a point 600 feet from tide water a shaft 100 feet deep has been sunk, and at this level 650 feet of drifting and crosscutting has been extended; 400 feet to the north a second shaft has been started.

The country rock exposed along the shore and up the creek bottom is principally greenstone schist with some black slate bands interstratified striking north and south with a dip of $70^{\circ} \mathrm{E}$. Open cuts have exposed several quartz veins and stringers interbedded and branching in various directions along jointing planes. At 40 feet elevation a quartz vein 4 feet wide containing galena, sphalerite, and pyrite crosses the creek and is parallel to the schistosity of the inclosing greenstone. Just above this, at an altitude of 50 feet, is a 2 -foot vein striking N. $85^{\circ}$ E., at right angles to the former, and dipping $80^{\circ} \mathrm{N}$. It has been developed by a 15 -foot shaft and open cut. The veins of this system, though usually small, are reported to contain higher values than those that parallel the structure of the inclosing rocks. The principal deposit on which the shaft has been sunk and the drifts extended consists of a mineralized belt of schist striking north and south and dipping $50^{\circ} \mathrm{E}$. and intersected across a width of 5 to 15 feet by a network of quartz and calcite stringers, in places having a banded flinty character. This has been traced several hundred feet in length, and the included rock as well as the stringers contain pyrite with some galena and sphalerite in small masses and disseminated particles varying from 2 to 4 pèr cent in amount. The gold values are combined principally with the pyrite, and the tests made yielded but a small per cent of free-milling gold, most of the values being contained in the concentrates.

\section{WORONKOFSKI ISLAND.}

General description.-Woronkofski Island occupies an area of about 25 square miles in Stikine Strait and lies just west of the town of Wrangell. It is heavily timbered to its mountain summits, which reach 1,500 feet in altitude. The rock exposures around its northern and eastern shore are argillites and schists. To the southwest these are intruded by a wide mass of granite, which occupies the western 
portion of the island. The ore occurrence on this island is of interest because the deposits are included in the granite intrusive.

Elephant Nose prospects.-The principal prospects in the vicinity of Elephant Nose are the Exchange group of several claims located in 1900. The mine workings are located near tide water in a cove just west of Elephant Nose. Here a quartz vein 12 to 15 feet wide is exposed by surface cuts and is undercut 25 feet in depth by a tunnel 45 feet long. This vein deposit crosscuts the granite striking north and south and dipping $30^{\circ} \mathrm{W}$., and includes small masses of the granite. The minerals contained are essentially pyrite and the vein is said to carry moderate values in gold.

\section{SMEATON BAY PROSPECTS.}

The prospects near Smeaton Bay are located on the mainland shore 2 miles south of Roe Point in Behm Canal. The mineral deposits at this point are situated within the metamorphosed schist-gneiss belt which flanks the Coast Range granite on the west and strikes ordinarily parallel to the shore line and dips at steep angles northeast or southwest. In the vicinity of this claim calc-mica schist and quartz-mica schist predominate, while farther north typical gneiss occurs. Dikes and bosses of granite intrude the complex at many points and are of the general Coast Range type of granodiorite. Two hundred paces south of the tunnel two such dikes of granodiorite 10 and 20 feet wide invade the schists and may bear a possible genetic relation to the ore body. The ore body consists of a mineralized belt or bands of calc-mica schist and is characterized by a well-marked slipping plane with gouge above its foot wall. The sulphide ore consists of pyrite, pyrrhotite, and chalcopyrite and is said to carry low values in gold and silver. Quartz, muscovite, and calcite constitute the gangue and are often stained brown and red by ferruginous weathering products. The claim is well located in respect to timber and transportation, and, although the values are not sufficiently high to warrant predictions of future production, the location near the Coast Range contact is unique for this region. This deposit was discovered in 1898 and has thus far been developed by 100 feet of tunneling and crosscutting, the mouth of the tunnel being located about 10 feet above the high-tide water mark. Only the annual assessment work has been done.

\section{UNUK RIVER PROSPECTS.}

Unuk River, one of the few large streams in southeastern Alaska, is very difficult to navigate even in a small boat. It rises about 55 miles from the head of Burroughs Bay, in Behm Canal, and traverses the entire granite portion of the eastern Coast Range. A low divide connects its head with a branch of Iskut River and thus serves as an east entrance way into the interior of British Columbia. The upper 
25 or 30 miles of the river drain the schist-argillite belt lying east of the Coast Range granite, which is characterized along its entire extent from British Columbia to the Skagway district by good silver and gold bearing veins. At the head of Portland Canal; on several of the Stikine River tributaries, especially Clearwater River, in the Atlin district and still farther north, this belt is known to carry both placer deposits and quartz ore bodies. It has long been knowi that similar deposits occur in the Unuk River region, and recently a company began the construction of a wagon road from salt water along the northwest bank of Unuk River to a group of claims 42 miles inland across the boundary in British Columbia territory: Both placer and quartz claims have been located and will probably become ore producers as development proceeds. Now that access to

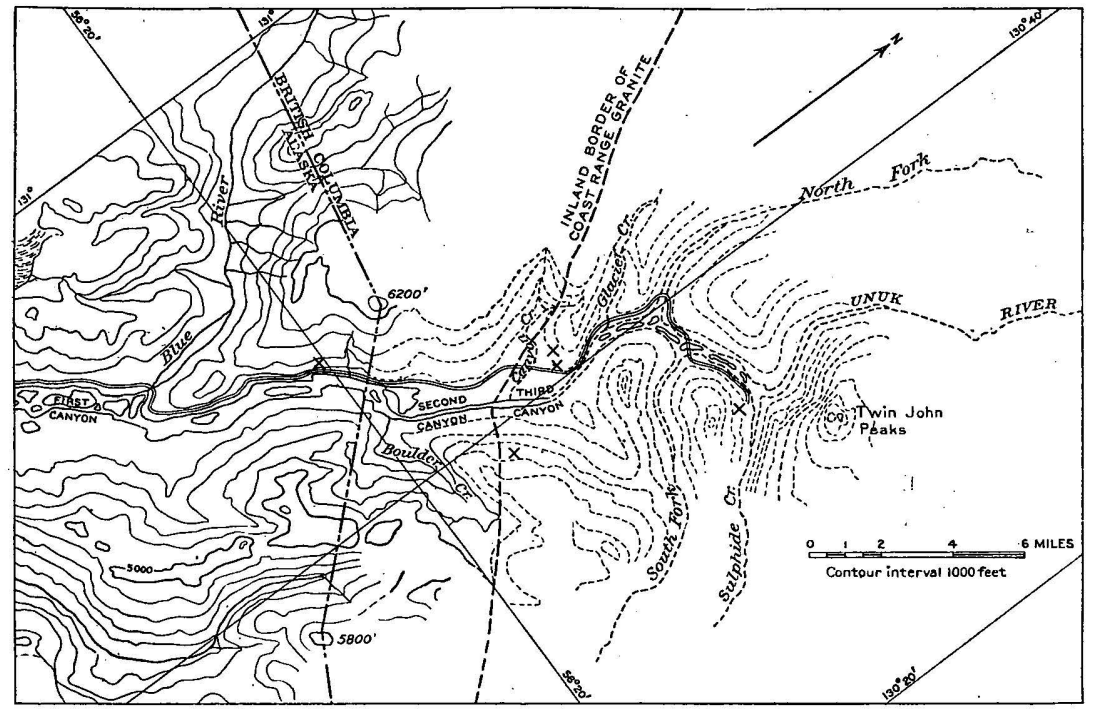

FIG. 21.-Sketch map showing positions of prospects on Unuk River and near the international boundary line.

the region has been made possible by the road, it is to be expected that during the coming season many prospectors will avail themselves of the opportunity to visit it and give it a thorough test. This field is not described in detail, because its mineralized belt, like that lying inland from the head of Portland Canal, appears to be entirely on the Canadian side of the boundary (see Pl. II and fig. 21). ${ }^{a}$

\section{SILVER, LEAD, AND ZINC MINES.}

GENERAL DESCRIPTION.

Deposits of silver, lead, and zinc ores are not plentiful in either the Ketchikan or the Wrangell districts. In only three localities are such being developed, and the ore production from these has been

\footnotetext{
- a Wright, F. E., Unuk River district: Summary Rept. Canadian Geol. Survey (for 1905) 1906, pp. 46-53.
} 
slight. Silver occurs in its sulphide form, usually associated with galena, and many specimens assay from 16 to 20 ounces per ton in silver. $^{a}$ It is also present in amounts varying from one-fifth ounce to 3 ounces per ton in the copper ores. The total production of silver in 1906 from these ores was $\$ 18,000$. In the gold ores its content is more variable and is dependent upon the amount of gold present, the ratio being approximately 2 ounces of silver to 1 ounce of gold. Lead occurs entirely in the form of galena and has been mined in small quantities from the properties on Coronation Island and the Moonshine property in Cholmondeley Sound. It is also present in the gold ores and rarely in the copper ores, but in such ores the lead content is of no value. Zinc is not known to occur in this region in commercially valuable amounts, and, though present to the amount of 5 to 10 per cent in some of the ores, its content is in most cases a detriment as it renders smelter treatment more difficult.

SOUTH ARM OF CHOLMONDELEY SOUND.

MOONSHINE GROUP.

Situation and development.-This property includes several claims and lies west of the South Arm of Cholmondeley Sound, about $1 \frac{1}{2}$ miles from tide water on the crest of the mountain ridge, at an elevation between 2,000 feet and 2,400 feet (see fig. 16). In 1906 these claims were located as the Moonshine group, and early in the spring were sold to the Alaska Galena Company. Developments were begun by this company in August, 1906, and in November were suspended for the winter. During 1907 operations were in progress from May until November.

The ore body has been developed by a shaft on the crest of the ridge 100 feet deep, and 550 feet to the west by a drift tunnel 200 feet in length, which is being driven to connect with the shaft at a point 225 feet below the surface. Besides the mine development considerable work has been expended on a horse trail from the beach to the mine, a distance of 2 miles.

Ore body.-The Moonshine vein, as it is called, occupies a welldefined fissure, cutting obliquely across limestone and schist country rock and traversing the top of the mountain ridge. Where it crosscuts the limestone it is apparently a replacement deposit, varying from a few inches to several feet in width and carrying considerable galena associated with quartz, siderite, and calcite, though where the schist forms the inclosing walls the vein is smaller and is in many places represented by a narrow gouge seam. The country rock strikes nearly east and west and dips north at steep angles, whereas the vein strikes $\mathrm{N} .65^{\circ} \mathrm{W}$. and has a vertical dip. In this vein deposit the mineral occurs irregularly, the ore being found in small scattered 
masses or bunches. Besides the galena a small anount of sphalerite and chalcopyrite is present, and silver values amounting to many ounces per ton occur in the ore. Very little surface alteration or secondary enrichment was observed, and where present it extends but a few feet in depth. Diabase dikes from 1 foot to 6 feet in width crosscut both the country rock and the ore body.

\section{GROUNDHOG AND GLACIER BASINS.}

General description.-These groups of claims are located on the mainland about 14 miles due west of Wrangell and are reached by trails starting from Eastern Passage and leading around Mill Lake, which occupies a basin 3 miles long, to Groundhog and Glacier basins, about 8 miles from tide water (see Pl. III and fig. 22). The ore

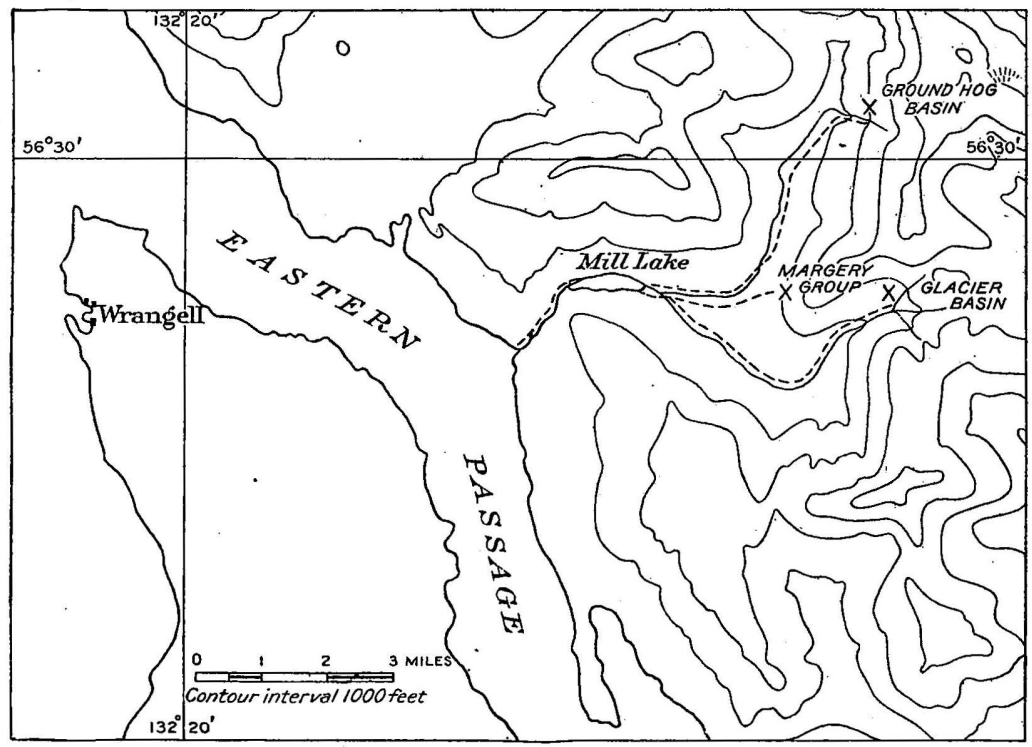

FIG. 22.- Sketch map showing location of Groundhog Basin and Glacier Basin prospects.

bodies occur in a slate-schist belt, which is included between the main Coast Range granite mass and an outlying granite belt averaging 1 to 3 miles in width and is intrusive approximately parallel to the bedding planes of the adjacent rocks. The total thickness of the included slate-schist belt is about 6,000 feet. Its N. $35^{\circ} \mathrm{W}$. course is indicated on the general map, the dip varying from $30^{\circ}$ to $60^{\circ} \mathrm{NE}$., into the mountains. The entire belt is considerably mineralized and. may be recognized by its red color, which is due to the oxidation of the sulphide minerals. This belt is penetrated by parallel and crosscutting acidic porphyry and aplitic dikes, along which the ore deposits are usually found. These dikes are younger than the granite and older than the basaltic dikes that occur here. Near the Coast Range 
granite contact the metamorphism of the schists is more intense than farther west, and at these points gneissoid rocks prevail. The degree of mineralization, however, is greater, and the aplitic and porphyry dikes are more numerous nearer the western intrusive granite. The claims which have been located in this belt are mostly above timber line and not easily accessible at present, as transportation facilities are lacking.

Glacier Basin group.-Glacier Basin, a rock-rimmed basin produced by glacial erosion (fig. 22), standing 2,100 feet above sea level, is reached by a trail 7 miles in length from Mill Lake. At the head of the basin Nelson Glacier still exists as evidence of the former ice sheet and is slowly retreating up the mountain cliffs. The claims of this group are located on the north side of the basin within the slate-schist belt and have been developed chiefly by two short drift tunnels and surface cuts. The rocks are practically bare, and the veins can be traced directly up the mountain slopes for long distances, varying from 4 to 20 feet in width, occurring unusually near or in the intrusive aplitic or porphyry dikes. The veins are heavily mineralized with galena, zinc blende, pyrite, and chalcopyrite. The values are in gold and silver and are only of fair average. The transportation difficulties are at present a very important drawback to these claims from a mining standpoint.

Georgia group.-The Georgia group of two claims is located on the south side of Glacier Basin on a vein parallel to the schistosity of the inclosing rock and similar in character to the Glacier Basin deposits though not so large. The developments on this group have been very slight.

Groundhog Basin group.-This property is located northwest of Glacier Basin in the same mineral belt and is reached by trail from Mill Lake about 4 miles in length (see fig. 22). The actual workings are located at 2,100 feet elevation on the north side of a steep gulch tributary to the main valley, at which point they can be observed at the contacts of the intrusive porphyry dikes in the slateschist belt. Surface oxidation has colored the veins dark red, so that they are visible from long distances and can be easily traced. At the Groundhog Basin group the vein is 6 feet and more in width, being heavily mineralized with galena, zinc blende, and pyrite. It has been exploited by two open cuts and short tunnels. The assay values are reported to be of only fair average. The persistence of these veins along the strike argues well for their continuation in depth.

Margery group.-The Margery group is located at an elevation of 1,500 feet on the west slope of the mountain spur which separates Glacier Basin and Groundhog Basin valleys and is more favorably situated for mining than most of the properties in this area (see fig. 22). At one point is a lode deposit consisting of quartz stringers 
1 foot to 5 feet wide following a definite zone parallel to the inclosing schist and near the contact of a large intrusive granite mass. Several open cuts and short tunnels expose this lode along its strike. To the northeast of this on the same claim is an open cut exposing a 12-foot vein rich in galena and similar in character to the other veins in this area. Mineralization is usually heavy, especially in galena, besides which sphalerite, chalcopyrite, native silver, cerusite, and limonite occur in varying amounts. The values are reported good, especially in silver.

CORONATION ISIAND PROSPECTS.

General description.-Coronation Island, which includes an area of 30 square miles, is one of the seaward islands which lies at the entrance to Sumner Strait 35 miles southwest of Shakan. Geographically it is made up of Paleozoic limestone and schist, which are intruded by a granite mass (see Pl. I). Discoveries of galena on this island were made in 1900 by sailors who were driven into Egg Harbor, on the northwest end, by a storm. These men found galena float on the west shore of the harbor and at points from 700 to 1,000 feet elevation deposits of the ore in place. They prospected these to some extent and in 1902 the Coronation Island Mining Company was formed, which has continued operations in a small way since that time. Three tunnels have been driven on three separate ore bodies: No. 1 at 980 feet elevation and 162 feet long; No. 2 at 860 feet elevation and 510 feet in length; No. 3 at 700 feet elevation and 110 feet long. Over 100 tons of the ore have been mined, sacked, and shipped to the smelter from this locality.

Ore bodies.-The ore deposits are narrow, irregular masses of galena ore in a limestone country rock, and few. exceed 20 feet in their greatest dimension, but at the lowest tunnel an irregular vein deposit containing small pockets of galena ore is exposed. At tunnel No. 1 the ore body, which is exposed at the entrance, is 8 feet wide, 8 feet by 12 feet in length, and about 18 feet in depth, the continuation of the tunnel exposing practically no ore. No. 2 tunnel has been driven along slipping planes in the limestone having a general N. $80^{\circ} \mathrm{W}$. strike with nearly vertical dip. At a point 296 feet from its mouth there is a short crosscut to the north, from which a 10 -foot raise has been extended along a galena body 3 feet wide by 15 feet in length and depth, following along one of the slipping planes. Just beyond this point a second crosscut has been driven, in which an altered diabase dike 5 feet in width was observed following the same trend of the slipping planes, but having no apparent connection with the ore deposits. The ore body shown in the lowest or No. 3 tunnel varies from 1 foot to 4 feet in width and has been followed for 100 feet in length. Here the hanging wall is well de- 
fined by a slipping plane, but the foot wall often merges into the limestone country rock and is but poorly defined. The ore occurs in small scattered pockets, the largest having been opened by a raise 60 feet from the tunnel entrance. Besides galena the sulphides, tetrahedrite and sphalerite are present in the ores, and near the surface limonite, cerusite, and smithsonite were noted.

\section{BUILDING STONES.}

\section{GENERAL STATEMENT.}

The recent developments and increasing production from marble quarries on Prince of Wales Island have shown that building stone is an important resource of this region. Other structural materials, such as granite, gypsum, cement, and clay deposits, are also widely distributed along this coast. Little consideration has been given to these nonmetallic products of this Territory, and the increasing use of such materials in the United States demands a more thorough investigation of these resources. Though distant from the market, many large deposits of structural material are well located for quarrying and for transportation by water.

The only stones of value in southeastern Alaska, so far as known, are the marbles and granites. The market for these stones is in the cities along the Pacific coast of the United States, 600 to 1,000 miles distant. They must, therefore, be of more than ordinary quality to bear the expense of freight, as good stone is found in the vicintiy of most large cities, and builders, as a rule, prefer to use a known rock which is near at hand and can be readily obtained.

To place the Alaskan product on the market, it.will be necessary to establish supply stations, with dressing and cutting plants, in the larger seaboard cities, where cheaper and more efficient labor may be obtained than in Alaska. To supply these points, the rough granite and marble could be transported in hulks or barges carrying several thousand tons at a low freight rate, and the necessity of careful handling during the shipment would be avoided.

To determine the structural value of a building stone, microscopical, chemical, and physical tests should be made. This is more necessary for marbles and cement stone than for granite. Most university laboratories are equipped for such tests and will make them at a reasonable cost.

\section{MARBLE.}

\section{DISTRIBUTION.}

Beds of marble are known to occur at points along the mainland portion of the Ketchikan and Wrangell districts as well as on many of the islands. They are invariably at or near the contact of an in- 
trusive belt of granodiorite, which has been one of the principal factors in metamorphosing the original limestone beds to their present crystalline or marbleized condition. The age of the limestone beds is Paleozoic, and only in a few places could a more definite determination be made. The largest deposits of marble under development are at the northwest end of Prince of Wales Island near Shakan and on Ham Island south of Wrangell.

\section{NECESSARY QUALITIES.}

Commercially marble includes all limestone rocks susceptible of receiving a good polish and suitable for ornamental work. It is not a simple matter to judge the value of a marble deposit, and this can not be done from mere tests of small samples, which, nevertheless, may often give significant results. Some of the more important factors governing the value of a body of marble are the quality and soundness of the stone as a whole, extent of the deposit, absence of fractures or joint planes, color, lack of objectionable impurities, such as silica, pyrite, and bitumen, facility of extraction, and location of the deposit relative to the market and transportation.

\section{COMPETITIVE DISTRICTS.}

Most of the marble used in the western cities for monumental and interior decorative purposes is furnished by eastern dealers and must be shipped across the continent. This is mainly the product of the Vermont and Tennessee quarries or is imported from Italy. Stevens County is the only produeing locality in the State of Washington; there are none in Oregon, and but two of importance, the Inyo and Columbia quarries, in California. The total value of the marble production for 1905 from these localities was less than $\$ 150,000$, This product is sold in a rough state at $\$ 1$ to $\$ 2$ per cubic foot, and dressed for ornamental or monumental purposes at $\$ 2$ to $\$ 8$ per cubic foot. Cut in slabs 1 inch to 2 inches thick and polished on one side, the retail price varied from $\$ 0.50$ to $\$ 1.50$ per square foot. The eastern and foreign marbles sold for higher prices.

DESCRIPTION OF LOCALITIES OF OCCURRENCE.

PRINGE OF WALES ISLAND.

ALASKĀ MARBLE COMPANY.

Situation and development.-The properties of the Alaska Marble Company are situated on Marble Creek a few miles north of Shakan, bordering the coast for 2 miles in length and over half a mile in width (see fig. 23). They are located upon a belt of Devonian lime- 
stone about 3,000 feet in width flanking the west side of an intrusive granite mass, which forms the low mountain ridge to the east and which is evidently the direct cause of the alteration of the limestone to marble. This deposit was first discovered in 1896 and finally located in 1905, the first work being done along the exposures in the creek bed one-half mile from the shore. From 1900 to 1904 prospecting was extended up the hillsides and drill holes sunk to ascertain the quality of the product in depth. Early in 1904 the Alaska Marble Company was incorporated and developments on a large scale were

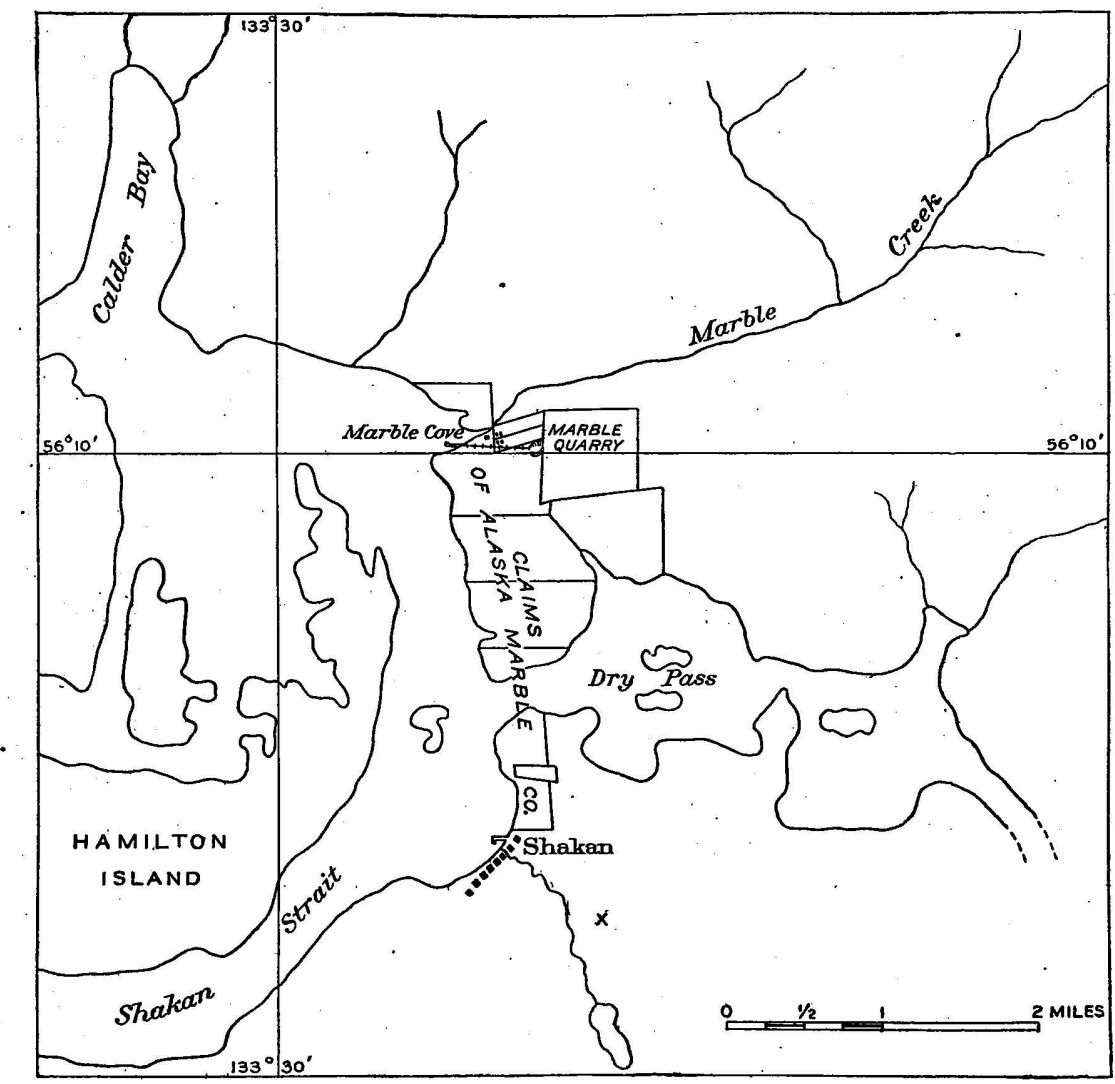

Frg. 23.-Sketch map showing marble quarry and locations of Alaska Marble Company. immediately begun. At present the plant consists of a wharf equipped with derricks, a gravity railroad to the quarry 3,200 feet in length, necessary channeling and gadding machines, and various buildings. At the quarry, located on the south side of Marble Creek at an elevation of 100 feet, an area 100 feet by 200 feet has been stripped and quarried to an average depth of 60 feet measured on the mountain side (Pl. XII, $A$ ). A test shipment of 100 tons was made in 1902, but actual production did not begin until early in 1906. The 
marble is now being placed on the market in the cities along the $\mathrm{Pa}$ cific coast. The manufacturing plant of the company is located at Tacoma, Wash.

The marble deposit.-The extent of the marble deposit at this locality has been investigated at a number of points on the surface by open cuts and trenches and in depth by 18 drill holes and at all of these places marble usually of good quality is exposed. As above noted, the marble belt is approximately 3,000 feet in width striking in a northwesterly direction and dipping to the southwest. It is limited on the northeast by an intrusive granite mass and on the southwest by the shore line. To the south it crosses the entrance to Dry Pass, but just back of Shakan it is cut off by a granite mass, while to the northwest it extends into the channel and reappears at the entrance to Calder Bay, extending northward and overlying beds of conglomerate. Along the shore exposures and at the quarry small dikes of diabase, striking northeasterly and much altered and faulted, were observed intersecting the marble beds. Apparently these dikes antedate the metamorphism of the limestone and therefore the intrusion of the granite. They are, however, but a foot or two in width and not sufficiently numerous to affect the value or expense of quarrying the marble. In the present opening at the quarry only one dike is exposed. Both surface cracks and slipping planes are present in the surface exposures of the marble, but in depth these are less numerous and will not materially interfere with quarrying (see PI. XII, $B$ ).

Three distinct varieties of marble are found-pure white, blueveined with white background, and light blue, often having a mottled appearance. The pure white, which has a finely crystalline texture, is the most valuable. All of the marble is free from silica and flint beds common in most quarries, and though thin seams of pyrite were observed they do not occur in a quantity detrimental to the stone. The following chemical analysis of the white marble was made by E. F. Lass for the Alaska Marble Company:

Chemical analysis of white marble from Marble Creek, Prince of Wales Island, Alaska.

Insoluble matter

Oxide of iron $\left(\mathrm{Fe}_{2} \mathrm{O}_{3}\right)$

Sulphuric anhydride $\left(\mathrm{SO}_{3}\right)_{\ldots}$

Lime $(\mathrm{CaO})$ -

Magnesia (MgO) -

Garbon dioxide $\left(\mathrm{CO}_{2}\right)$ -

Undetermined _..- 44

Total --_---1-- 100.00

Calcium carbonate $\left(\mathrm{CaCO}_{3}\right)$ - 99.26 


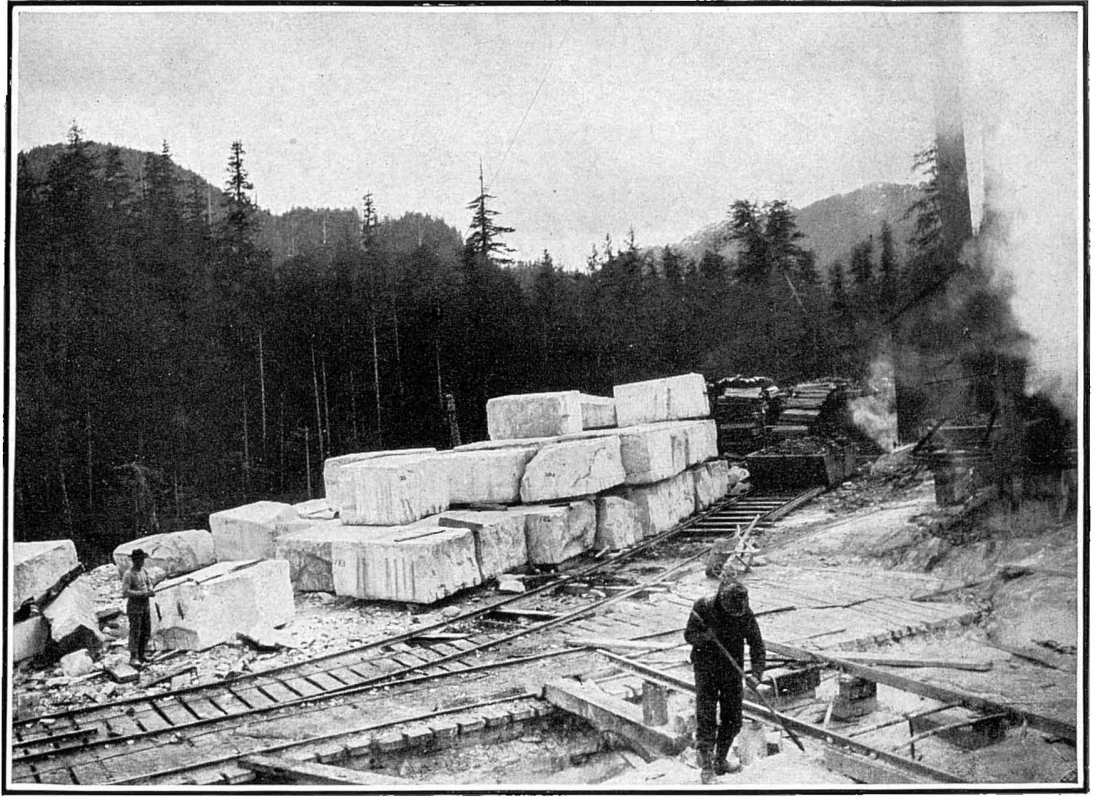

A. MARBLE BLOCKS READY FOR SHIPMENT, QUARRIED FROM MARBLE CREEK DEPOSITS.

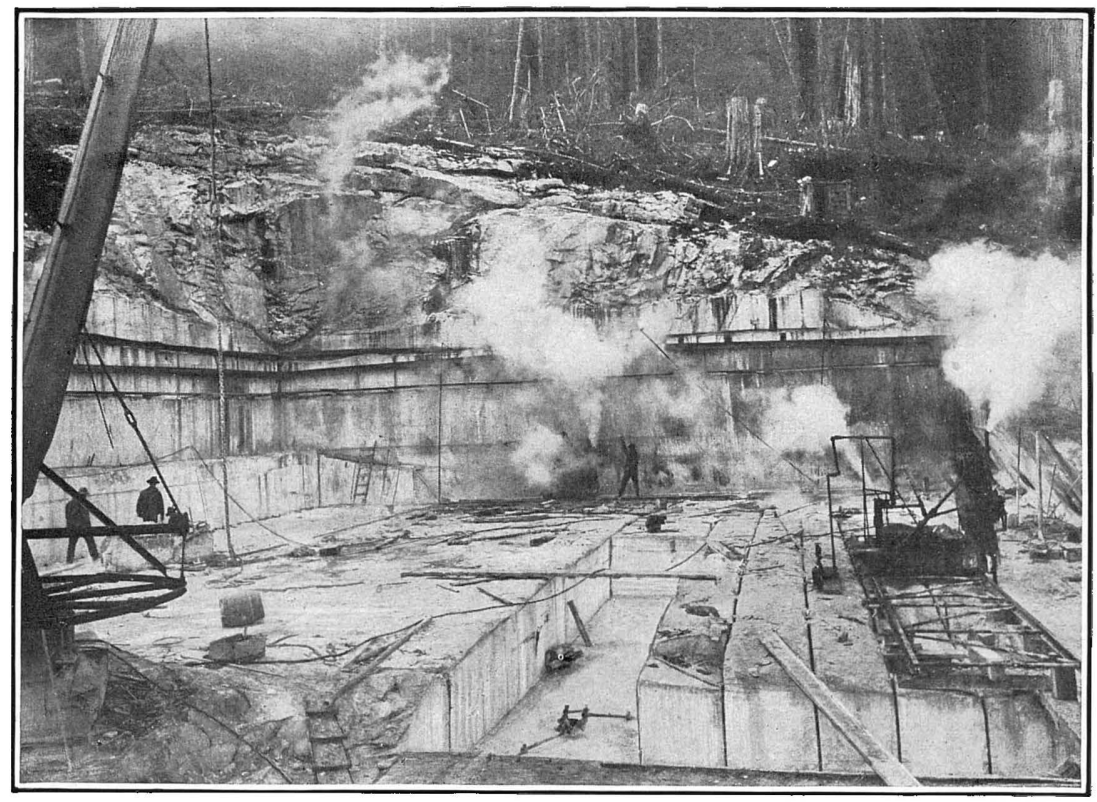

B. MARBLE QUARRY WORKINGS OF THE ALASKA MARBLE COMPANY, 3 MILES NORTH OF SHAKAN, ON PRINCE OF WALES ISLAND. 

A qualitative test for magnesia in a sample collected by the writers was made by Dr. George Steiger, of the United States Geological Survey, who reports a content of less than 1 per cent.

To determine the crushing strength of the stone the Alaska Marble Company submitted samples to N. H. Winchell, State geologist of Minnesota, who reports an average strength of 10,521 pounds per square inch, a strength ample for all building purposes. Though not equal to the best Italian grades, this marble is better than most American marbles, and in the market will compete on at least equal terms with the product of Vermont, Georgia, and Tennessee.

Method of quarrying.-At the quarry it was first necessary to remove the uppermost layers of the more or less fractured marble. This was done by channeling machines, a method which is preferable to blasting, as it does not injure the massive rock in depth. The machine used is mounted with "donkey" engine on a truck and cuts a channel 2 inches in width at a rate of 7 to 8 square feet per hour. These channels are extended to a depth of 4 feet and are made at intervals of 4 or 6 feet in one direction and at intervals of 6 feet at right angles so as to form blocks 4 to 6 feet by 6 feet in surface area and 4 feet in depth. These blocks are undercut by gadding machines, in which a drill is set so as to drill a series of holes under the block, and in these holes wedges are driven and the block is freed from its base. It is then lifted by a derrick to the car on which it is carried to the wharf. The blocks contain from 96 to 144 cubic feet of marble and weigh from $7 \frac{1}{2}$ to 11 tons each, the dimensions depending on the handling capacity of the machinery (Pl. XII, $A$ ). The larger part of the marble product is shipped in the rough state to a sawing and. polishing plant at Tacoma, where it is prepared for the market. Small shipments have also been made to Chicago, Milwaukee, St. Louis, Cincinnati, and other points for trial tests.

\section{EL CAPITAN MARBLE COMPANY.}

The property of the El Capitan Marble Company is situated on the eastern side of a low mountain range 5 miles due east of the Alaska Marble Company's quarry and on the north side of Dry Pass. These locations, including ten claims, were first made in 1901 and were sold to the El Capitan Marble Company in 1903. Except for a small amount of assessment work, operations were not begun until April, 1904. During that year a quarry. consisting of a pit 12 feet deep was opened on a marble deposit close to tide water, a channeling and gadding machine was installed, and a cutting plant operated by steam power was erected. Some marble was quarried and shipped to Seattle at the close of the year, but since that time operations have been suspended. 
The marble deposit flanks the eastern side of the granite mass represented on the geologic map, and from its relative position and general character is similar to the Marble Creek deposit farther west. The marble belt is exposed at tide water and forms high bluffs at 200 to 400 feet elevation one-fourth mile back from the shore. In these bluffs it has been prospected by trenches and open cuts. Several diabase dikes crosscut the marble beds. The dikes are faulted and show in many places several feet of displacement, though this faulting as well as the intrusion of the dikes probably occurred previous to the metamorphism of the original limestone beds, as no trace of the fault planes could be seen, and the dikes themselves were-much altered and sheared. The marble as exposed in the quarry is not of so good quality as that from the Marble Creek property, being less firm and more coarsely crystalline. Surface cracks and fracture planes are present in the surface exposures, but in the bottom of the pit these features are less pronounced.

MARBLE ISLAND.

Marble Island, a low wooded area of 9 square miles, is one of the larger islands in Davidson Inlet and lies 10 miles due south of Sha.kan, though by water it is nearly 30 miles distant. . On the northwest side of this island marble was first discovered in 1899, and in 1903 a number of claims were located over this portion of the island and a small amount of stripping was done. Samples of this marble were quarried for test purposes and several varieties of good quality obtained. The total developments have not exceeded the assessment requirements.

The marble deposit is exposed in a cove on the northwest side of the island, and at 100 feet elevation, a half mile from the shore, it has been worked by an open cut. A considerable area is underlain by marble, though little is known of its extent or value. Along the eastern shore of the island an area of granitic intrusive rock was noted.

AMERICAN CORAL MARBLE COMPANY.

General description.-The properties of the American Coral Marble Company are located at two localities-(1) at the head of North Arm, where twelve claims have been located along the north shore of the Inlet, and (2) at the north entrance to Johnson Inlet, where the company has several claims extending from Dolomi eastward to Clarence Strait (see Pl. I). The principal developments have been made at the North Arm property, and at this point a post-office named Baldwin has been established. Active work at this locality began in 1904, and the marble deposits were prospected during that year. In 1905 a wharf was built, machinery installed, and buildings erected pre- 
paratory to quarrying the marble. During 1906, however, practically no work was done, and all of the machinery was removed in 1907. At the Dolomi property a small quarry was started on the hillside, at a point a quarter of a mile northeast of Dolomi postoffice and a few. hundred feet from tide water on the Clarence Strait side, and buildings were erected. No operations were in progress at these localities during 1907.

Marble deposits.-The deposits at North Arm and at Dolomi consist of marble beds interstratified with chloritic and calcareous schists, striking northwest with steep dips usually southwest. The surrounding area is mantled by a dense growth of vegetation, and the limits of the deposits have not been definitely determined, though where the marble is exposed it is much fractured, variable in color and composition, and intersected by a few narrow dikes of diabase. The fracture planes were probably formed principally during the period of tilting and folding of the beds and existed before erosion exposed the present surface outcrops. Since that time weathering has accentuated and to some extent increased the number of fracture planes, and it seems probable, however, that in depth these planes, although potentially present as lines of weakness, will become less numerous and will not interfere greatly in quarrying.

Although some parts of the deposits consist of pure white, finegrained marble of excellent quality, other parts are poorly colored, coarse-grained, and of little commercial value, and it will probably be difficult to obtain large quantities of uniform grade. The better grade is reported to give the following analysis: Calcium carbonate, 94 per cent; alumina, 3.9 per cent; silica, 1.4 per cent; magnesia, 0.7 per cent. Pyrite is also present in small amounts, occurring in thin seams and finely disseminated in some of the marble.

\section{REVILLAGIGEDO ISLAND.}

A well-defined limestone belt traverses the eastern portion of Revillagigedo Island in a northwesterly direction and is exposed in Thorne Arm, Carroll Inlet, and George Inlet (see Pl. II). Its widest development is on the north side of George Inlet, near the head, where marble claims known as the Bawden group were located in 1904. The deposit is included in the crystalline schist near the contact with the less-altered slates to the southwest. The marble beds range from 10 to 20 feet in width and are separated by strata of calcareous schist. Their strike is northwest and their dip northeast. The marble is exposed in cliffs near tide water and is of good quality, being relatively free from fracture and joint cracks, finely crystalline, and from white to gray in color. No large developments have been started on this property. 
In Carroll Inlet, to the southeast, claims have also been located on the samè belt, but at this locality the deposit is not so extensive as in George Inlet.

\section{HAM ISLAND.}

Ham Island lies at the junction of Blake Channel and Bradfield Canal, 25 miles southeast of Wrangell (see Pl. III). It is about a mile and $a$ half wide and consists largely of crystalline limestones with interstratified beds of calcareous schist striking N. $35^{\circ} \mathrm{W}$. and dipping $75^{\circ} \mathrm{NE}$. Intrusive dikes of basalt are common, and across the narrow channel on the mainland and on Wrangell Island wide belts of granite intrude the limestone and schist beds and have probably induced the present crystalline texture in the limestone and thus formed the marble.

Two distinct varieties of marble are found-one fine grained and pure white, the other very coarse grained and pale blue. Several systems of joint planes traverse the deposits, but the joints are widely separated and will not interfere greatly in quarrying. Checks or surface cracks are practically absent, and wide areas of massive marble have been found directly underneath the soil. Much of the marble appears to be free from impurities.

Two groups of claims have been located on this island-the Woodbridge-Lowery group on the west side and the Miller group on the east side. On the former the marble quarried is principally of a white, finely crystalline variety, but at the Miller property the deposit, exposed in a bluff 40 feet high and 100 feet long, is of a coarsely crystalline texture and a bluish color. On both of these properties considerable exploratory work has been done, and large blocks of the marble have been quarried, and from these tombstones and small blocks have been chiseled and polished for local use. The properties are favorably located both for quarrying and transportation.

\section{GRANITE.}

\section{DISTRIBUTION.}

The granitic intrusive rocks occupy about one-half of the aggregate land area of the Ketchikan and Wrangell districts (see Pl. I). In composition they range from granite to granodiorite or to quartz or hornblende diorite. The core of the Coast Range, as well as the central portion of many of the islands, is composed of this intrusive rock. The metamorphism in the granite, its nonuniformity in color, and the presence of joint cracks, so far as observed, make most of the stone undesirable for building purposes. However, granite masses of good quality, uniform in color, and favorably located for purposes of quarrying, were observed along the mainland up Portland Canal, in 
Behm Canal, and at Thomas Bay. On the islands numerous granite stocks occur, portions of which are of massive and uniform texture, though in these stocks are many segregations of the femic minerals, and pyrite is present in many places, rendering the rock less desirable for building purposes.

\section{CHARACTERISTICS. ${ }^{a}$}

All the granite masses in this region are similar in composition, having plagioclase feldspar as an essential constituent. Hornblende is the usual dark mineral, though biotite mica is present in much of the rock and in a few places exceeds in amount the hornblende. Quartz is commonly present, though usually in small amounts. The accessory components are apatite, titanite, and magnetite; secondary minerals, due to general metamorphism, are sericite, epidote, zoisite, chlorite, and calcite. Petrographically much of the rock is related more closely to the diorites than to the granites and is usually referred to as a diorite.

The prevailing color is light gray, and in only a few places were pink or reddish masses observed. The grains of the component minerals are ordinarily of medium size, not varying greatly in the different localities. Evidence of the durability of the granite is afforded in many places where long exposure to the influence of weathering has caused little or no disintegration of the surface.

MARKET.

No attempt has yet been made to quarry or even investigate the Alaskan granite. There is practically no market in Alaska for the stone, and along the Pacific coast to the south the demand has been supplied by the quarries in the States of Washington, Oregon, and California.

The long haul necessary to reach the market appears at first unfavorable to granite quarrying along this portion, of the northwest coast, but the present freight rate of less than $\$ 3$ per ton to Puget Sound is not greater than the cost of transportation from some of the quarries in California to the larger cities. The cost of quarrying the stone is estimated at 40 cents per cubic foot, and the proportion of marketable rock obtained from the amount quarried is about 60 per cent.

The value of the production of granite from the States along the west coast amounted to nearly $\$ 1,000,000$ in 1905 . The average selling price per cubic foot for building purposes at the quarries in the coast States in 1906 was as follows: Rough, $\$ 0.85$; dressed, $\$ 2.35$; for curbing, $\$ 1$. For monumental purposes the stone sold for $\$ 1$ to $\$ 2$ per cubic foot rough and for $\$ 3$ to $\$ 6$ per cubic foot dressed.

\footnotetext{
a The characteristics of the granitic intrusives are described in detail on pp. 61-69.
} 
The prices do not include the cost of transportation from the quarries to the cities, which is from $\$ 0.50$ to $\$ 3$ per ton. This adds from 5 to 30 cents to the cost per cubic foot.

\section{CEMENT.}

There are several kinds of cement, the principal kinds being Portland cement and natural cement. Portland cement is produced by burning a finely ground artificial mixture containing essentially lime, silica, and alumina in certain definite proportions. Usually this combination is made by mixing limestone or marl with clay or shale, and in such a mixture should contain about three parts of the carbonate to one part of clayey material. Natural cement is the product of an impure limestone containing from 15 to 40 per cent of silica, alumina, and iron oxide. Calcareous and argillaceous rocks suitable for cement making are relatively scarce in the Ketchikan and Wrangell districts. They are metamorphosed, usually containing mica and some pyrite, and are not sufficiently fine grained to be of value. At only one locality-Long Island in Kasaan Bay-have rocks of this sort been located for the manufacture of cement. Here beds of limestone and siliceous shale are exposed around the shores of the island and are apparently of a quality suitable to make cement. The disposition of this product will, however, be confined to the local market, as it can not now be profitably shipped to compete with the cement manufactured along the Pacific coast. The reason for this, in the first place, is the high cost of the fuel necessary for its manufacture. The difficulty in obtaining efficient and cheap labor, as compared with the labor of the Puget Sound area and California, must also be considered. The long haul necessary to reach the market is unfavorable to such an industry. To ship the cement rock as mined to a cement factory established somewhere near the point of coal supply and near the market would be the most feasible plan, but this would bring little or no profit, as vast areas of cement rock are exposed near all the larger cities and can supply the cement plants along the coast for many years to come.

\section{MINERAL AND THERMAL SPRINGS.}

Cold mineral springs have been found at (1) St. John Harbor, on Zarembo Island, (2) at several points near Eddystone Rock, in Behm Canal, and (3) up Unuk River.

At Zarembo Springs the water contains considerable carbon dioxide with various mineral salts, which lend to it an agreeable flavor. The point of outflow, which is covered at high tide, has been incased and a small wharf built over it. The water forces itself up through 
a pipe, from which demijohns and barrels are filled and shipped to Seattle, where bottling works have been established.

In Behm Canal the principal spring is situated on the east side of Revillagigedo Island, opposite Eddystone Rock. The waters emerge from fracture cracks in a banded schist complex cut by pegmatite dikes. The flow at this point is greater than at Zarembo Springs. Carbon dioxide and a small percentage of sulphureted. hydrogen are present in the water, the latter giving it a disagreeable odor. Small shipments have been made from these springs for the local trade.

On the north bank of Unuk River, about 20 miles from the mouth and $2 \frac{1}{2}$ miles below the international boundary, a strongly carbonated spring flows from a fissure in the granite. Its temperature is $7^{\circ}$ C. $\left(44^{\circ} \mathrm{F}\right.$.) and the daily discharge about 1,000 gallons. With good transportation facilities this spring should prove valuable.

Thermal springs occur at several points in southeastern Alaska and have been found by experience to possess medicinal properties of great value to sufferers from rheumatism and other ills resulting from exposure. The Indians were the first to appreciate the healing power of the springs and made use of them long before the invasion of the white men. Of late years cabins and bath houses have been built at several of the springs for the accommodation of visitors. Southeastern Alaska, however, is not an ideal summer resort, owing to the excessive rain, and the springs can not be so valuable commercially as those in more favored districts.

The springs occur without exception within intrusive granite belts and issue from fracture planes. In temperature they range from $65^{\circ}$ C. $\left(150^{\circ}\right.$ F. $)$ to $95^{\circ}$ C. $\left(203^{\circ} \mathrm{F}\right.$. $)$. They are extremely variable in composition, and on cooling precipitate various minerals, forming crust deposits. The rate of discharge is not the same for different springs, and varies, probably, from several hundred to $1,500,000$ gallons per day. One of the hottest springs is located near Bailey Bay, Behm Canal, in the Ketchikan district. The water at this point issues from a fissure in the granite in the form of a jet 15 inches high and 1 inch in diameter. On Bell Island, just west of Bailey Bay, and on the north side of Unuk River, 6 miles from its mouth, are similar hot springs, which are frequently visited. The spring with the greatest flow is situated opposite Great Glacier, on Stikine River, above the international boundary, and serves the inhabitants of the Wrangell district. Definite analyses and temperatures of the various waters could not be obtained. 


\section{FUTURE OF THE DISTRICTS.}

Although a greater or less concentration of copper and gold occurs at various points in the Ketchikan district, there is little to indicate that deposits of much higher grade or greater extent will be found than those at present mined. Large areas still remain unprospected, and within these future explorations will probably reveal ore bodies comparable with those now known. The extent of the copper-bearing masses is possibly the most important question to be settled. That outcrops may fail altogether to indicate the value of ground underneath has been shown at several localities, and that the occurrence of the ore is often in limited masses which can be mined out in a short space of time is shown at several mines, though at these localities advanced developments invariably reveal new ore bodies. Under exploitation on the scale being advanced in this district the problem of new ore reserves must inevitably come to the front, and the search for new ore bodies should be vigorously continued by both prospector and mine operator. Such investigations have been satisfactorily extended in the ore-bearing rocks by the use of diamond-drills, which are especially adapted to the search of such scattered ore masses.

Under existing conditions, with the price of copper at 15 cents per pound, it is not possible to mine profitably ore containing less than 60 pounds of copper per ton and the usual gold content of from 75 cents to $\$ 1.25$ per ton. However, ore containing as low as 40 pounds of copper per ton was mined and shipped at a profit early in 1907, when copper was at a market value of 25 cents a pound. The present mining costs average from $\$ 1.50$ to $\$ 2$ per ton, including haulage to the wharf; transportation to the smelters at Tacoma or in British Columbia costs from $\$ 1.50$ to $\$ 2$ per ton, depending upon the tonnage shipped; smelting charges are from $\$ 3$ to $\$ 5$ per ton, including the losses in treatment. If the ore is smelted in Alaska, transportation is somewhat reduced, though the smelting charges are necessarily increased, as the coke required must be shipped to Alaska and the copper matte or smelter product must be shipped south to Puget Sound.

In some of the copper mines, as on Kasaan Peninsula and near Sulzer, are huge bodies of magnetite containing from 1 to 2 per cent of copper per ton, which can not at present be extracted with profit as a copper ore. It is possible, however, that, with the introduction of a method of concentration by fine grinding and magnetic separation, such an ore may also be mined to advantage, especially if the magnetite can be sold as an iron ore. It is noteworthy that the magnetite is practically free from phosphorus, contains very little sulphur or other impurities, and could be placed on the market as a "Bessemer 
ore." The mines and prospects on Kasaan Peninsula alone have revealed a large tonnage of magnetite ore.

Gold ores which are favorably located and in which the greater percentage of the value is free-milling can be profitably mined with a gold content of $\$ 3$ to $\$ 10$ or more per ton, according to the magnitude of the ore body.

The rapidly increasing output from the copper mines on Prince of Wales Island and the recent discoveries of copper-bearing deposits have brought the Ketchikan district well to the front as a copperproducing area. Little can be said regarding the future of the mines. and prospects in the Wrangell district, as their output has been slight. Copper, gold, and silver-lead deposits are being exposed at several localities, some of which give promise of becoming future metal producers. 



\section{N D E X .}

A. Page.

Acknowledgments to persons aiding....... 12

Admiralty Island, area of.................. 23 fossils of............................. 58 geology of................... 37,39-40,58 mineralization on ..................... 42

Alameda claim, description of ............ 170

Alaska, southeastern, geography of....... 21-22 geology of......................... $32-43$ map of ............................. 22 work in ............................. 9

Alaska Marble Company, marble of...... 194-195 marble of, analysis of................ 194 quarries of ....................... 192-195 map showing................... 193 views of .................... 194

Alexander Archipelago National Forest, description of $\ldots \ldots \ldots \ldots \ldots \ldots . \quad 32$

rules for $\ldots . . \ldots \ldots \ldots \ldots \ldots \ldots \ldots \ldots . .32$

Alexander claim, description of ........ 155-156

Algonquin group, description of.......... $\quad 140$

Alpha group, description of............. 175

Amazon claim, description of........... 174-175

American Coral Marble Co., properties of. 196-197

Amphibole, occurrence and character of.... 92

Andesite, occurrence and character of ..... 71-72

Annette Island, area of ................... 23 gold deposits of................... 179-180

Indians on .......................... 179-180

Annie claim, description of............... $\quad 156$

Arsenopyrite, occurrence and character of.. $\quad 89$

Ashe group, description of . . . . . . . . . . 150-151

Atwood, W. W., work of ............... 57

Azurite, occurrence and character of ....... 90

$B$.

Baby George claim, description of......... 147

Baker Island, description of............. 181-182 mineralization on.................... 80

Baltic claim, description of.............. 148

Baltic Star claim, description of............ 148

Baranof Island, geology of.............. $\quad 38$ mineralization on...................... 42

Barnard, William, explorations by ........ 17

Baronovich, Charles, copper development by .......................... 16

Basalt, occurrence and character of....... 72

Batholiths, occurrence and character of .... 36,37 See also Coast Range intrusives.

Bawden, James, explorations by ........... 17

Bay View claim, description of............ 140

Beauty claim, description of............. 175

Becker, G. F., surveys by................ 14-15
Behm Canal, description of ............... $25-26$

springs on.......................... 201

Bell Island, springs on.................. 201

Bibliography of region.................. 14-15

Big Five claim, description of............ 127

Big Joe claim, description of.............. 140

Biotite, occurrence and character of........ 93

Birdseye claim, description of............. 152

Black Warrior claim, description of...... 102-103

Black Warrior group, description of........ 140

Blake, W. P., survey by ................. 14,19

Blue Bird claim. See Sleepy Eye claim.

Blue Bucket claim, description of . ...... 156-157

Bornite, description of................. 87

Boundary Peak, view from............... 24

Bradfield Canal, views on................. 68

Breccia veins, occurrence and character of. 81-82

Brooks, A. H., preface by . . . . . . . . ........ 9 work in charge of . .................. 11-13,15

Brown and Metzdorf prospect, description

of . ....................... 120-121

Bruce, M. W., on Prince of Wales Island..... 16-17

Buckhorn group, description of ........... 165

Building stones, markets for............ 191-192 occurrence and value of.............. 191-200

C.

Calcite, occurrence and character of ........ 90

Canals. See Fiords.

Carboniferous rocks, deposition of......... 74 description of ................ 34-35, 44,52-57 fossils of............................ $52-56$

Carita group, description of . . . . . ......... 140

Carroll Inlet, marble on................. 197-198

Cascade group; description of............ 161-162

Cement, character of..................... 200 materials for

Cenozoic rocks, description of ............. 34, 43-44

Chalcopyrite, analyses of ores of........... 86 description of ..................... 86-87

Charles prospect, description of ........... 120

Chatham Strait, description of........... 21-22

Chichagof Island, geology of . . . . . . . . . . . . . 38 mineralization on..................... 42

Chlinochlore, occurrence and character of... 93

Cholmondeley Sound, description of ........ 166 gold mines near ................... 166-172 location of, maps showing . . . . . . . 167, 169 lead and silver mines on ............. 187-188

Chrysocolla, occurrence and character of ... 90

Cleveland Peninsula, description of ....... 152-153 gold mines on ..................... 153-158 
Page

Climate, description of ............... 27-29

Clipper group, description of .

165

Clover Bay, fossils from . . . . . . . . . . . . . . 49-50

Coal, occurrence of . ................... 59-60

Coal Bay, section at................... 60

Coast Range intrusives, composition of .... . 63-65

contacts of . . . . . . . . . . $61-62$

description of . . . . . . . . . . . . . . . . . . $61-69$

metamorphism by . . . . . . . . . . . . . 65-68

mineralization of . . . . . . . . . . . . . . . . . . $77-78$

Concord group, description of ........... 139-140

Constitution group, description of ......... 163

Contact-metamorphic deposits, occurrence and character of.

Conundrum claim, description of ........ 131

Copper, price of . . . . . . . . . . . . . . . . . . . 202 production of . . . . . . . . . . . . . . . $19-20,77$

Copper, native, occurrence of . ........... 86

Copper Center group, description of ......... 120

Copper City mine, description of . . . . . . . . . 106 ore body of . . . . . . . . 106. assay of ........................ 85

Copper Cliff mine, description of .......... 131

Copper Harbor, copper ores on . . . . . . . . . . . 107-108 smelter at. . . . . . . . . . . . . . . . . . . . . . . . 9 97-98

Copper mines, detailed descriptions of . . . . 93-142

Copper mining, cost of ................. 202 development of .................... 77

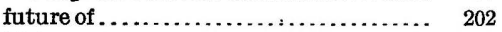

history of $\ldots \ldots \ldots \ldots \ldots \ldots \ldots \ldots \ldots . \ldots 16,19-20$

Copper Mountain, workings on, views of . . . . 98

Copper Mountain group, description of . . . . . 96-97 developments at . . . . . . . . . . . . . . . . 97-98 ore deposits of ...................... 98

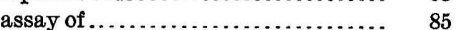

Copper ores, assays of................. 85 character of ..................... 84-85

Copper Queen mine, description of . . . . . 117-118 development of .................... 16

Corbin mine, description of . . . . . . . . . . 105 ore bodies of ...................... 105-106

Coronation Island, description of . . . . . . 190 galena on . . . . . . . . . . . . . . . . . . . 80, 190-191

Crackerjack mine, description of . . . . . . . 160-161

Cretaceous rocks, description of........... 34

Crœsus group, description of . . ........ 170-171

Cushing, H. P., surveys by ............... 14

Cutter group, description of . ........... 165

Cymru mine, description of........... . . . 132-133 ore bodies of . ..................... 133-134 analysis of ................... 85

\section{D.}

Dakoo Harbor prospects, description of... 181 Dall, W. H., surveys by . . ................ 14-15

Dall Head, fossils from near. . . . . . . . . . . 52-53

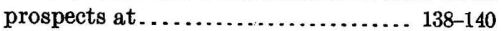
location of, map showing......... 139

Dall Island, area of ..................... 23 description of . . . . . . . . . . . . . . . . . 180-181 gold prospects on ................... 181 mineralization on.................. 79

Dama group. See Copper Cliff mine.

Dawson, G. M., surveys by ................ 14

Devonian rocks, deposition of. .......... 73-74 description of .................. $35,46-52$ fossils from
Page.

Dew Drop claim........................ 163 Diabase dikes, occurrence and character of. $69-70$ Diamond B. claim, description of........ 102-103 Dikes, occurrence and character of........ 68-69 view of ........................... 68

Dolly Varden claims, description of....... 162

Dolomi region, description of............ 172-173 gold mine of ..................... 172-176 marble near........................ 196-197

Dora Bay, gold prospects on ........... 171-172 Dora Lake, prospects near, location of, map showing.................... 167 Drainage, description of ................. 24-26 Duncan, William, work of, among Indians. $\quad 179$ Duncan Canal, copper mines near........ 140-142 copper mines near, location of, map showing..................... 141 description of...................... 140-141

E.

Eagles Nest group, description of........ 118-119 El Capitan Marble Co., quarries of....... 195-196 Elephant Nose prospects, description of.... $\quad 185$ Elk group, description of................ $\quad 181$ Emerson, B. K., surveys by.............. 15 Epidote, occurrence and character of....... 92 Equator group, description of............. 168 Etolin Island, area of .................... 23

Extrusive rocks, definition of.............. 44 description of ........................ $70-73$ Eureka claim, description of............. 121 F.

Faults, occurrence and character of....... 40 Fawn group. See Kid group.

Feldspar, occurrence and character of ...... 92-93 Felsite dikes, occurrence and character of .. $\quad 70$

Field work, description of............... 12-13

Fiords, character and occurrence of ..... 21-22, 24

Flora claim, description of ............... 162

Folds, occurrence and character of........ 39

Forest; national, establishment of........... 32

Formations. See Rock formations.

Fortune claim, description of............. 175

Frisco claim, description of.............. 170

G.

Galena, analyses of .................... 88 occurrence and character of........... 88

Garnet, analyses of ..................... 91 occurrence and character of . .......... 90-92

Geography, description of............... 21-27

Geologic history, outline of ............... 73-77

Geologic maps of area................. Pocket. description of .................. 13-14,43-45

Geology of Ketchikan and Wrangell districts....................... 43-77 of southeastern Alaska................ 32-43 views showing $\ldots \ldots \ldots \ldots \ldots \ldots \ldots, 26,56,68$

George claims, description of ............. 161

George Inlet region, description of ....... 149-150 fossils from ........................... 55-56 gold mines of ..................... $150-151$ map of ............................. 149 marble of ....................... 197

Girty, G. H., fossils identified by.......... 52-56 work of.......................... 12 
Page.

Glaciation, extent of.

Glacier Basin, description of

lead, zinc, and silver of . . . ......... 189-19n map. of.

Gladstone group, description of . . . . . . . 166-167

Go-by group, location of............... 165

Gold, occurrence of . ...... 77, 78, 82, 85-86, 142-143 production of ..................... 20

Golden Banner claim, description of...... 147

Golden Fleece group, description of ..... 175-176

Golden Rod claim, description of. ....... 146-147

Gold mines, detailed descriptions of . . . . . 142-186

Gold mining, cost of .................... 203 history of . . . . . . .

Gold Mountain group, description of...... 156

Gold ores, character of . . . . . . . . . . . . . 85

Gold Standard group, description of . . . . 153-155

Goldstream group, description of. . . . . . 177-178 ore bodies of . . . . . . . . . . . . . . . . . . . . 178

Goodro claims, description of . . . . . . . . 125-126

Googoo claim, description of . . . . . . . . . 147

Gould group, description of ............. 107

Gould Island, copper ores on . ........... 107

Granite, application of term............ 63 characteristics of . . . . . . . . . . . . . . . . ... 199 distribution of . . . . . . . . . . . . . . . . . 198-199 market for ...................... 199-200 See also Coast Range intrusives.

Granite Mountain, description of.......... 164 prospects on. ...................... 164-166

Gravina Island, copper mines on. . . . . . . 138-140 description of . . . . . . . . . . . . . 138,177 fossils from.................... 50,52-53 gold mines on. .................. 177-179 map of part of . . . . . . . . . . . . . . . . . 139

Green Monster group, description of ...... 102 developments at.................... 102 ore bodies of. ..................... 102-103

Greenstone, occurrence and character of. .. 70-71

Grotto claim, description of............ 140

Groundhog Basin, description of . . . . . . . 188-189 lead, zinc, and silver of. ............ 189-190 map of

\section{H.}

Hadley, claims near, map showing ........ 113 view of, showing smelter............ 100

Halleck Harbor, fossils from . . . . . . . . . . . . . 54-55

Hamilton Bay, fossils from . . . . . . . . . . . . 59-60

Ham Island, marble on. ............... 198

Harris River claims, description of. . . . . . . 161

Hattie group, description of . . . . . . . . . . . 182-184

Hayes, C. W., surveys by ... . . . . . . . . . . . . . 14

Heceta Island, fossils from............. 47

Heckman group, description of ........... 179

Helen S. group, description of............ 184

Helm Bay, gold mines on.............. 153-154 map of . . . . . . . . . . . . . . . . . . . . . 154

Hematite, occurrence and character of. . . . 89

Hetta Inlet region, copper mines of . . . . . 94-108 description of . . . . . . . . . . . . . . . . . . . . 94 geology of ..................... 95 map of ........................ 96 metamorphism in . . . . . . . . . . . . . 95-96 mines of, descriptions of . . . . . . . . . 96-108 ore deposits of . ..................... 95-96

Hetta Mountain, copper ores on......... 108
Page.

High Horse claim, description of . . . . . . . 147-148

Hilma claim, description of................. 121

Historical geology, outline of . . . . . . . . . . 73-77

Hoadley group, description of ............ 151

Hobo claim, description of.............. 140

Hoffman claim, description of . . . . . . . . . 155-156

Hole in the wall prospects, description of. . 121-122

Hollis, gold mines near . . . . . . . . . . . . . . 158-164 location of, map showing. ........... 159

Hollis group, description of. . ............ 161

Homestake claim, description of.......... 176

Hope claim, description of. ........... 176-177

Houghton group, description of . . . . . . . . 103-104

ore bodies of . ...................... 104

Humboldt claim, description of ........... 161

I.

Idaho claim, description of . . . . . . . . . . 171-172

Igneous rocks, description of . . . . . . . . .44,61-73

Independent group, description of. . . . . . . 163-164

Index claim, description of ............... 104

Indian claim, description of . . . . . . . . . . 97-98

Intrusive rocks, definition of........... 33

description of . . . . . . . . . . .

See also Batholiths; Coast Range intrusives.

Iola claim, description of . ............. 102

Iron Cap group, description of . . . . . . . . . . 126-127

Islands, description of . . . . . . . . . . 26-27

mineralization on .................... 42

$$
\text { J. }
$$

Johnson Inlet, marble at............... 196

Joker group. See Goodro claims.

Judge claim, description of . . . . . . . . . 129-131

Julia claim, description of . ............. 161

Jumbo group, description of. . . . . . . . . . $\quad 99$

developments at. . . . . . . . . . . . . . . 99

ore deposits of . . . . . . . . . . . . . . . 99-102

Juneau belt, description of . .......... 41

Juneau group, location of. . . . . . . . . . . . . 165

Juneau district, survey of . . . ............ 9,11

K.

Karta Bay mine, ore of, assay of . ........ 85

Karta Bay region, copper mines of . . . . . . 122-126 description of . . . . . . . . . . . . . . . . 122 geology of....................... 122 map of. ......................... 123 mines on, descriptions of . . . . . . . . 123-126

Kasaan Bay region, copper prospects of. - 127-128

Kasaan Peninsula, copper mines on. . . . . 1 08-12 description of . ................... 108-110 geology of . . . . . . . . . . . . . . . . 110-111 iron on . . . . . . . . . . . . . . . . . . . . 202-203 map of. ......................... 109 mines of, descriptions of . . . . . . . . . . 112-122 ore deposits of . . . . . . . . . . . . . . . 111-112

Keku Islets, fossils from . . . . . . . . . . . . . . 53-54

Keokuk claims, description of........... 161

Ketchikan, description of............... 18

Ketchikan district, area of . . . . . . . . . . . 23 boundaries of . . . . . . . . . climate of . . . . . . . . . . . . . . . . . . 27-29 future of $\ldots \ldots \ldots \ldots \ldots \ldots \ldots \ldots \ldots \ldots . \ldots \ldots 20.203$ geography of . . . . . . . . . . . . . . . 22-27 geologic maps of . . . . . . . . . . . . . Pocket: 
Ketchikan district, geology of........... $43-77$ mining development in.............. 16-17 vegetation in . . . . . . . . . . . . . . . . . 30-32

Ketchikan series, definition of ........... 44

Keystone claim, description of . . . . . ..... 157

Khayyam mine, description of.......... 135 ore bodies of . . . . . . . . . . . . . . . . . . ore of, analysis of .................. 137 plan and section of, figures showing.... 136

Kid group, description of .............. 169-170

Kindle, E. M., fossils found by . . . . . . . 46-51,55 work of . . . . . . . . . . . . . . . . . . . . . 12

Kitkun Bay, gold prospects on ......... 168-171 location of, map showing . ............ 169

Klawak Inlet, fossils from.............. 51

Kloochman Canyon, view of.............. 26

Knowlton, F. H., fossils identified by . . . . . 59-60 Kosciusko Island, area of . ............. 23

Kuiu Island, area of. ................. 23 coal on . ......................60,72-73 description of . ................. 26-27 fossils from . . . . . . . . . . . . . $46,53-55,60$ geology of....................... 72 mineralization on .................... 80

Kupreanof group, description of . . . . . . . . 141-142 location of, map showing........... 141

Kupreanof Island, area of . . . . . . . . . . . . . . 23 copper mines on . . . . . . . . . . . . . . . . 140-142 description of . ................... ${ }^{\bullet} 26$

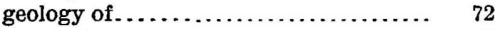
mineralization on .................... 42

\section{L.}

Lady of.the Lake claim, description of . . . . 171 Lake claims, description of............ 149

Lake group, description of. . . . . . . . . . . 171

Lake View claim, description of . . . . . . . . 137 ore bodies of . . . . .

Laskawonda group, description of . . . . . . • 152

Last Chance claim, description of........ 157

Lava. See Intrusive rocks.

Lead mines, description of . . . . . . . . . . . . . 187-191 distribution of. .................... 186-187

Limonite, occurrence and character of . . . . . 90

Literature, account of ............... 14-15

Little.Annis claim, description of......... 176

Lode deposits, occurrence and character of. 82-83

Lon-de-Van group, description of . ........ 150

Long Island, cement materials on ........ 200 fossils from ....... geology of $\ldots \ldots \ldots \ldots \ldots \ldots \ldots \ldots \ldots . \ldots \ldots 110-111$ section on .......................... 48

Lookout group, description of.......... 131

Lucky Find group, description of ......... 165

Lucky Jim group, description of. .......... . 165

Lynn Canal, description of . ........... 21-22

M.

McKenzie Inlet, copper mines on ....... 134-138 copper mines on, location of, map show-

ing ....................... 134

Magnetite, occurrence and character of. 89,202-203 Mahoney group. See Iron Cap group.

Majestic claim, description of............ 147

Malachite, occurrence and character of .....
Mamie mine, description of . ......... $\begin{gathered}\text { Page. } \\ \text { 112-114 }\end{gathered}$

location of, map showing ............ 113

ore body at . ...................... 114

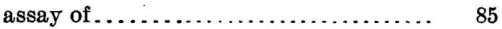

Mammoth group (Kasaan Peninsula), description of . . . ............. 119 ore body at . .................. 119-120

Mammoth group (Skowl Arm), description of $\ldots \ldots \ldots \ldots \ldots \ldots \ldots \ldots \ldots . \ldots \ldots$

ore bodies of . . . . . . . . . . . . . .

Map, of southeastern Alaska . . . . . . . . . . 22

Maps, geologic, of area............... Pocket. description of ................. 13-14,43-45

Marble, blocks of, view of . . . . . . . . . . . . . 194 distribution of . . . . . . . . . . . . . . . . . . 191-192 market for ......................... 192 occurrences of, description of ........ 192-198 quality of .......................... 192

Marble Island, marble on............... 196 Margery group, description of . . . . . . . . . 189-190

Mary T. claim, description of.......... 157 Massachusetts claims, description of .... 148-149 Melville claim, description of . . . . . . . . . 155-156 Mesozôic rocks, deposition of :.......... $75-77$ description of ................ 43, 57-58

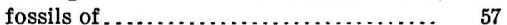
intrusion of $\ldots \ldots \ldots \ldots \ldots \ldots \ldots \ldots \ldots .75-76$ Metamorphism, description of. . . . . . . . 65-68 Metlakatla, Indians at............... 179-180 Midnight Sun claim, description of ....... 155 Mineralization, occurrence and character of . . . . . . . . . . . . $41-43,77-80$ See also Ore deposits; Ores.

Minerals, description of . . . . . . . . . . . . . 85-93 Mineral springs, occurrence and character of .................... 200-201

Mines and prospects, detailed descriptions of . .................. 93,191

Mining development, history of . . . . . . . . . 16-19

Mitk of Island, area of.................. 23

Moira Sound, North Arm of, copper mines on ..................... 132-134

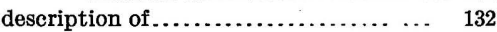
map of ......................... 133

Molybdenite, occurrence and character of ... $\quad 89$ Moonshine group (Cholmondeley Sound), description of .............. 187-188

Moonshine group (Gravina Island), description of .................. 179

Mountain Top claim, description of........ 156 Mount Andrew mine, description of .... . 115-116 location of, map showing........... 113 ore bodies at.................... 116-117 assay of...................... 85 plan and section of, figure showing..... $\quad 116$ Mount Anvil, view from ................ 24 Mount Vesta prospects, description of..... 181

N.

Nellie claim, description of . . . . . . . . . 162-163 New York claim, description of... . . . . . . 97-98 Niblack Anchorage region, copper mines of . . . . . . . . . . description of ..................... 128 geology of..................... 128-129 map of ............................ 129 
Page.

Niblack mine, description of............. $129-130$ ore bodies of ..................... 130-131

assay of........................ 85

North Arm, gold prospects on.......... 176-177 marble on........................ 196-197

Noyes Island, mineralization on.......... $\quad 80$

O.

o. K. claim, description of................ 168 Old Glory group, description of ......... 157-158

Omar Khayyam mine, ore of, assay of....... 85 Ore deposits, character of . . ............. 80-84 distribution of ..................... $77-80$ minerals of . ....................... 85-93 See also Ores; individual mines.

Oregon claim (Dora Bay), description of.. 171-172 Oregon claim (Kitkun Bay), description of ..................... 168-169

Ores, character of. $68-169$
84

\section{P.}

Pacific Mountain system, deseription of.... 21 Palache, C., surveys by .................. 15 Paleozoic rocks, description of..... 34-35, 43, 45-57 Paris group, description of................ 107 Park View claim, description of.......... 168 Paul and Jessie claims, description of . ... 173-174 Pay shoots, character of ................ $\quad 81$ Peacock claim, description of............ 121 Pegmatite, importance of. ............ 63,68-69 Pelaska claim, description of............. 122 Pennsylvania claims, description of....... 122 Peterson group, description of........... 150 Placers, development of ................ $\quad 80$

Platinum, nonoccurrence of ................

Point Meade limestone, fossils of.

Poor Man's group, description of...........

Porphyrite dikes, occurrence and character of...........................

Portage Mountain group, description of.... location of, map showing...............

Port Camden, fossils from.

Portland Canal, description of . view of.

Precipitation, records of.

Prince of Wales Island, area of.

contact-metamorphism on............ copper mines on................. 93-134,203 description of ........................ 26,27 fossils from ..................... $47-50,52$ geology of ..................... $40,58,59$ gold mines on.................... 158-177 marble on ....................... 192-197 mineralization on ............ 16-17, $22-43,79$

Prindle, L. M., fossils found by ............. 56 Prospects and mines, detailed descriptions of ...................... 93-191

Puyallup mine, description of .......... 159-160

Puzzler claim, description of.............. 155

Pyrite, description of ..................... $\quad 87$

Pyrrhotite, analyses of ores of ........... 87 description of....................... 87

\section{Q.}

Quartz, occurrence and character of........ Queen claim, description of
R.

Page.

Rainy Day claim, description of.......... 156 Reid, H. F., surveys by ................. 14

Revillagigedo Island, area of............. 23 gold mines on. marble on........................ 197-198 springs on ......................... 201

Rock formations, description of........... 36-38

Rose claim, description of ............... 163

Rush \& Brown mine, description of . ...... 123-125 ore bodies of ...................... 125 section of, figure showing.............. 124 Russian Bear claim, description of ......... 108

Saginaw Bay, fossils from . ... . . . . . $\ldots \ldots \ldots . .53,54$

Salmon claim, description of............... $\quad 175$

Salve claim, description of ............... 148

San Fernando Island, geology on, view of... $\quad 56$

San Juan Bautista Island, fossils from ...... 51

San Juan claim, description of .............. 171

Scapolite, occurrence and character of..... 92

Schist band, definition of................. 44 view of ............................ 68.

Sea Breeze claim, description of ........... 146

Seal Bay, prospects at................. 138-140 prospects at, location of, map showing. . $\quad 139$

Sealevel, gold mines near, map showing..... 145

Sealevel mine, description of .............. 144-146

Seaward islands. See Islands.

Sedimentary rocks. See Stratified rocks.

Shelton group, description of ............. $\quad 128$

Silurian rocks, deposition of . .............. 73 description of..................... $35,45-46$ fossils of ............................. 46

Silver, production of ..................... 20

Silver mines, description of . . . . . . ......... 187-191 distribution of ..................... 186-187

Skowl Arm, copper mines near ........... 134-138. copper mines near, location of, map showing.................... 134 description of ......................... 134

Slate belt, definition of ................... 44

Slate-greenstone band, definition of ...... 44,56-57 mineralization in.................... 78 view of ................................ 56

Sleepy Eye claim, description of............. 176 Smeaton Bay prospects, description of...... $\quad 185$ Soda Springs Bay, fossils from .............. 52 Spencer, A. C., surveys by ................. $\quad 15$ Sphalerite, occurrence and character of..... 88 Springs, occurrence and character of ...... 200-201 Stanton, T. W., fossil identified by.......... $\quad 57$ Starry Banner claim, description of ........ $\quad 156$ Stella claim, description of ................ 162

Stevenstown mine, description of......... $\quad 114$ location of, map showing............. 113 ore bodies at......................... $\quad 115$ assay of ......................... 85 workings of, view of .................. 100

Stikine River, description of .............. $\quad 25$ gold on............................ 18 springs on........................... 201 view on............................ $\quad 26$

Stratified rocks, definition of............. 32-33 description of ..................... $45-61$ See also Stratigraphy. 
Stratigraphy, description of $\quad . . . . .33-36$

table of . ................................ 34-35

Structure, description of ................ 38-40

Sultana group, description of ............. 104

ore bodies of ...................... 104-105

Sulzer, magnetite near.................. 202

Sunny Day group, description of.......... 127

Sunrise claims, description of ........... 121-122

Surveys, progress of ..................... 9

T.

Tacoma claim, description of ............ 121

Taku Harbor, fossils from............... 55

Taylor Creek prospects, description of...... 142

Taylor prospect, description of........... 119

Telegraph group. See Lon-de-Van group.

Temperature, records of.

Tertiary rocks, deposition of .

description of.

77

Tetradymite, occurrence and character of.. 88-89

Tetrahedrite, occurrence and character of. . $\quad 88$

Texas claim, description of.

Thermal springs, occurrence and character of....................... 200-201

Thorne Arm region, description of........ 143 geology of ......................... 143 gold mines of ..................... 143-149 location of, map showing............. 145 marble of........................... 197

Timber; distribution of .................. 30-31 preservation of ...................... 32 value of... 31

Tolstoi Bay region, copper mines of ..... 126-127 description of ....................... 126

Tolstoi group, description of ............. 127

Tongass Narrows, description of .......... 151 gold mines of ...................... 151-152 map of ............................ $\quad 149$

Topography, description of............. 23-27 view showing........................ 24

Treasuire group, description of......... 164-165

Triassic rocks, description of ............. 34

Twelve Mile Arm region, description of..... 158 geology of ........................ 158-159 gold mines of.................... 159-166 map of ............................. 159

Tyee claim, description of .............. 148

$\mathrm{U}$.

Uncle Sam mine, description of........... 117

United States claim, description of......... 157
Unuk River, prospects on, description of.. Page, prospects on, location of, map showing. $\quad 186$ springs on ......................... 201

V.

Vallenar Bay, prospects at............... $\quad 140$

Valparaiso group, description of ......... 173-174 workings in, section of, figure showing.. 174

Vegetation, description of.............. 30-32 growth of.......................... 31

Vein deposits, occurrence and character of . 80-81 Veins. See Breccia veins.

Venus claims, description of............. 122

Venus group, description of............... 125

Virginia group, description of............ 181

Vulcan claim, description of ............. 104-105

W.

Wakefield group, description of........... 132

Wales series, definition of................. 45

Wallace group, description of................ 127

War Eagle claim, description of........... 140

Washington claim, description of ......... 168-169

Westlake group, description of............ 176

White Knight group, description of....... 140

Wild Cat group, description of.......... 151-152

Wild West claim, description of........... 147

Woewòdski Island, description of.......... 182 gold mines on ...................... 182-184 map of............................ 183

Wollastonite, occurrence and character of.. $\quad 92$

Woronofski Island, description of........ 184-185 gold prospects on ..................... 185

$\begin{array}{rr}\text { Wrangell, description of...................... } & 19\end{array}$

Wrangell district, area of ................... 23 boundaries of ........................ 17 climate of......................... 27-29

future of............................. 202-203

geography of...................... 22-27 geologic maps of.................... Pocket. geology of........................ 43-77 mineralization in ..................... 41 mining development of . . ............. 18-19 vegetation in . . . . . . . . . . . . . . . . . . . . 30 .

Wrangell Island, area of................... 23

Wright, C. W., work of................ 12-13

Wright, F. E., work of.................. 12-13

Z.

Zarembo Island, area of ................ 23 Zarembo Springs, description of. ........ 200-201

Zinc mines, description of............. 187-191 distribution of . .................... 186-187 


\title{
RECENT SURVEY PUBLICATIONS ON ALASKA.
}

\author{
[Arranged geographically. A complete list can be had on application.]
}

All of these publications can be obtained or consulted in the following ways:

1. A limited number are delivered to the Director of the Survey, from whom they can-be obtained, free of charge (except certain maps), on application.

2. A certain number are delivered to Senators and Representatives in Congress for distribution.

3. Other copies are deposited with the Superintendent of Documents, Washington, D. C., from whom they can be had at prices slightly above cost.

4. Copies of all Government publications are furnished to the principal public libraries throughout the United States, where they can be consulted by those interested.

\section{GENERAL.}

The geography and geology of Alaska, a summary of existing knowledge, by A. H. Brooks, with a section on climate by Cleveland Abbe, jr., and a topographic map and description thereof, by R. U. Goode. Professional Paper No. 45, 1906, $327 \mathrm{pp}$.

Placer mining in Alaska in 1904, by A. H. Brooks. In Bulletin No. 259, 1905, pp. 18-31.

The mining industry in 1905, by A. H. Brooks. In Bulletin No. 284, 1906, pp. 4-9.

The mining industry in 1906, by A. H. Brooks. In Bulletin No. 314, 1907, pp, 19-39.

Railway routes, by A. H. Brooks. In Bulletin No. 284, 1906, pp. 10-17.

Administrative report, by A. H. Brooks. In Report on progress of investigations of mineral resources of Alaska in 1904: Bulletin No. 259, 1905, pp. 13-17.

Administrative report, by A. H. Brooks. In Report on progress cf investigations of mineral resources of Alaska in 1905: Bulletin No. 284, 1906, pp. 1-3.

Administrative report, by A. H. Brooks. In Report on progress of investigations of mineral resources of Alaska in 1906: Bulletin No. 314, 1907, pp. 11-18.

Notes on the petroleum fields of Alaska, by G. C. Martin. In Bulletin No. 259, 1905, pp. 128-139.

The petroleum fields of the Pacific coast of Alaska, with an account of the Bering River coal deposits, by G. C. Martin. Bulletin No. 250, 1905, 64 pp.

Markets for Alaska coal, by G. C. Martin. In Bulletin No. 284, 1906, pp. 18-29.

The Alaska coal fields, by G. C. Martin. In Bulletin No. 314, 1907, pp. 40-46.

Methods and costs of gravel and placer mining in Alaska, by C. W. Purington. Bulletin No. 263, 1905, 362 pp. (Out of stock; can be purchased from Superintendent of Documents, Washington, D. C., for 35 cents.) Abstract in Bulletin No. 259, 1905, pp. $32-46$.

Geographic dictionary of Alaska, by Marcus Baker, second edition by J. C. McCormick. Bulletin No. 299, 1906, 690 pp.

Administrative report, by A. H. Brooks. In Report on progress of investigations of mineral resources of Alaska in 1907. Bulletin No. 345, pp. 5-17.

The distribution of mineral resources in Alaska, by A. H. Brooks. In Report on progress of investigations of mineral resources of Alaska in 1907. Bulletin No. 345 , pp. 18-29.

The mining industry in 1907, by A. H. Brooks. In Report on progress of investigations of mineral resources of Alaska in 1907. Bulletin 345, pp. 30-53.

Prospecting and mining gold placers in Alaska, by J. P. Hutchins. In Bulletin No. 345,1908 , pp. 54-77.

Water-supply investigations in Alaska in 1906-7, by F. F. Henshaw and C. C. Covert. Water-Supply Paper No. 218; 1908, 156 pp.

\section{Topographic maps.}

Alaska, topographic map of; scale, 1:2500000. Preliminary edition by R. U. Goode. Gontained in Professional Paper No. 45. Not published separately.

Map of Alaska showing distribution of mineral resources; scale, 1:5000000; by A. H. Brooks. Contained in Bulletin 345 (in pocket).

Map of Alaska; scale, 1:5000000; by Alfred H. Brooks. 
In preparation.

Methods and costs of gravel and placer mining in Alaska, by C. W. Purington. Second edition.

\section{SOUTHEASTERN ALASKA.}

Preliminary report on the Ketchikan mining district, Alaska, with an introductory sketch of the geology of southeastern Alaska, by Alfred H. Brooks. Professional Paper No. 1, 1902, 120 pp.

The Porcupine placer district, Alaska, by C. W. Wright. . Bulletin No. 236, 1904, 35 pp.

The Treadwell ore deposits, by A. C. Spencer. In Bulletin No. 259, 1905, pp. 69-87.

Economic developments in southeastern Alaska, by F. E. and C. W. Wright. In Bulletin No. 259, 1905, pp. 47-68.

The Juneau gold belt, Alaska, by A. C. Spencer, pp. 1-137, and A reconnaissance of Admiralty Island, Alaska, by C. W. Wright, pp. 138-154. Bulletin No. 287, $1906,161 \mathrm{pp}$.

Lode mining in southeastern Alaska, by F. E. and C. W. Wright. In Bulletin No. $284,{ }^{\prime} 1906$, pp. $30-53$.

Nonmetallic deposits of southeastern Alaska, by C. W. Wright. In Bulletin No. 284, 1906, pp. 54-60.

The Yakutat Bay region, by R. S. Tarr. In Bulletin No. 284, 1906, pp. 61-64.

Lode mining in southeastern Alaska, by C. W. Wright. In Bulletin No. 314, 1907, pp. $47-72$.

Nonmetalliferous mineral resources of southeastern Alaska, by C. W. Wright. In Bulletin No. 314, 1907, pp. 73-81.

Reconnaissance on the Pacific coast from Yakutat to Alsek River, by Eliot Blackwelder. In Bulletin No. 314, 1907, pp. 82-88.

Lode mining in southeastern Alaska in 1907, by C. W. Wright. In Bulletin No. 345, 1908 , pp. 78-97.

The building stones and materials of southeastern Alaska, by C. W. Wright. In Bulletin No. 345, 1908, pp. 116-126.

Copper deposits on Kasaan Peninsula, Prince of Wales Island, by C. W. Wright and Sidney Paige. In Bulletin No. 345, 1908, pp. 98-115.

\section{Topographic maps.}

Juneau Special quadrangle; scale, 1:62500; by W. J. Peters. For sale at 5 cents each or $\$ 3$ per hundred.

Topographic map of the Juneau gold belt, Alaska. Contained in Bulletin 287, Plate XXXVI, 1906. Not issued separately.

\section{In preparation.}

Physiography and glacial geology of the Yakutat Bay region, Alaska, by R. S. Tarr, with a chapter on the bed-rock geology by R. S. Tarr and B. S. Butler.

The Ketchikan and Wrangell mining districts, Alaska, by F. E. and C. W. Wright.

Berners Bay Special map; scale, 1:62500; by R. B. Oliver. (In press.)

Kasaan Peninsula Special map; scale, 1:62500; by D. C. Witherspoon and J. W. Bagley.

CONTROLLER BAY, PRINCE WILLIAM SOUND, AND COPPER RIVER REGIONS.

The mineral resources of the Mount Wrangell district, Alaska, by W. C. Mendenhall. Professional Paper No. 15, 1903, 71 pp. Contains general map of Prince $\bigvee / i l l i a m$ Sound and Copper River region; scale, 12 miles = 1 inch. (Out of stock; can be purchased from Superintendent of Documents for 30 cents.)

Bering River coal field, by G. C. Martin. In Bulletin No. 259, 1905, pp. 140-150.

Cape Yaktag placers, by G. C. Martin. In Bulletin No. 259, 1805, pp. 88-89.

Notes on the petroleum fields of Alaska, by G. C. Martin. In Bulletin No. 259, 1905, pp. 128-139. Abstract from Bulletin No. 250.

The petroleum fields of the Pacific coast of Alaska, with an account of the Bering River coal deposits, by G. C. Martin. Bulletin No. 250, 1905, $64 \mathrm{pp}$.

Geology of the central Copper River region, Alaska, by W. C. Mendenhall. Professional Paper No. 41, 1905, $133 \mathrm{pp}$.

Copper and other mineral resources of Prince William Sound, by U. S. Grant. In Bulletin No. 284, 1906, pp. 78-87.

Distribution and character cf the Bering River coal, by G. C. Martin. In Bulletin No. 284, 1906, pp. 65-76. 
Petroleum at Controller Bay, by G. C. Martin. In Bulletin No. 314, 1907, pp. 89-103. Geology and mineral resources of. Controller Bay region, by G. C. Martin: Bulletin No. $335,1908,141 \mathrm{pp}$.

Notes on copper prospects of Prince William Sound, by F. H. Moffit. In Bulletin No. 345,1908 , pp. $176 \div 178$.

Mineral resources of the Kotsina and Chitina valleys, Copper River region, by F. H. Moffit and A. G. Maddren. In Bulletin No. 345, 1908, pp. 127-175.

Topographic maps.

Map of Mount Wrangell; scale, 12 miles $=1$ inch. Contained in Professional Paper No. 15. Not issued separately.

Copper and upper Chistochina rivers; scale, 1:250000; by T. G. Gerdine. Contained in Professional Paper No. 41. Not issued separately.

Copper, Nabesna, and Chisana rivers, headwaters of; scale, 1:250000. D. C. Witherspoon. Contained in Professional Paper No. 41. Not issued separately.

Controller Bay region Special map; scale, 1:62500; by E. G. Hamilton. For sale at 35 cents a copy or $\$ 21.00$ per hundred.

General map of Alaska coast region from Yakutat Bay to Prince William Sound; scale, 1:1200000; compiled by G. C. Martin. Contained in Bulletin No. 335.

\section{In preparation.}

The Kotsina-Chitina copper region, by F. H. Moffit.

Chitina quadrangle map; scale, 1:250000; by T. G. Gerdine and D. C. Witherspoon.

\section{COOK INLET AND SUSITNA REGION.}

The petroleum fields of the Pacific coast of Alaska, with an account of the Bering River coal deposits, by G. C. Martin. Bulletin No. 250, 1905, 64 pp.

Coal resources of southwestern Alaska, by R. W. Stone. In Bulletin No. 259, 1905, pp. 151-171.

Gold placers of Turnagain Arm, Cook Inlet, by F. H. Moffit. In Bulletin No. 259, 1905 , pp. $90-99$.

Mineral resources of the Kenai Peninsula; Gold fields of the Turnagain Arm region, by F. H. Moffit, pp. 1-52; Coal fields of the Kachemak Bay region, by R. W. Stone, pp. 53-73. Bulletin No. 277, 1906, 80 pp.

Preliminary statement on the Matanuska coal field, by G. C. Martin. In Bulletin No. 284, 1906, pp. 88-100.

A reconnaissance of the Matanuska coal field, Alaska, in 1905, by G. C. Martin. Bulletin No. 289, 19,06, $36 \mathrm{pp}$. (Out of stock; can be purchased of Superintendent of Documents for 25 cents.)

Reconnaissance in the Matanuska and Talkeetna basins, by S. Paige and A. Knopf. In Bulletin No. 314, 1907, pp. 104-125.

Geologic reconnaissance in the Matanuska and Talkeetna basins, Alaska, by S. Paige and A. Knopf. Bulletin No. 327, 1907, 71 pp.

\section{Topographic maps.}

Kenai Peninsula, northern portion; scale, 1:250000; by E. G. Hamilton. Contained in Bulletin No. 277. Not published separately.

Reconnaissance map of Matanuska and Talkeetna region; scale, 1:250000; by T. G. Gerdine and R. H. Sargent. Contained in Bulletin No. 327. Not published separately.

Mount McKinley region; scale, 1:625000; by D. L. Reaburn. Contained in Professional Paper No. 45. Not published separately.

\section{ALASKA PENINSULA AND ALEUTIAN ISLANDS.}

Gold mine on Unalaska Island, by A. J. Collier. In Bulletin No. 259, 1905, pp. 102-103.

Gold deposits of the Shumagin Islands, by G. C. Martin. In Bulletin No. 259, 1905, pp: $100-101$.

Notes on the petroleum fields of Alaska, by G. C. Martin. In Bulletin No. 259, 1905, pp. 128-139. Abstract from Bulletin No. 250.

The petroleum fields of the Pacific coast of Alaska, with an account of the Bering River coal deposits, by G. C. Martin. In Bulletin No. 250, 1905, 64 pp.

Coal resources of southwestern Alaska, by R. W. Stone. In Bulletin No. 259, 1905, pp. 151-171.

The Herendeen Bay coal field, by Sidney Paige. In Bulletin No. 284, 1906, pp. 101-108. 


\section{YUKON BASIN.}

The coal resources of the Yukon, Alaska, by A. J. Collier. Bulletin No. 218, 1903, $71 \mathrm{pp}$.

The gold placers of the Fortymile, Birch Creek, and Fairbanks regions, by L. M. Prindle. Bulletin No. 251, 1905, $89 \mathrm{pp}$.

Yukon placer fields, by L. M. Prindle. In Bulletin No. 284, 1906, pp. 109-131.

Reconnaissance from Circle to Fort Hamlin, by R. W. Stone. In Bulletin No. 284, 1906, pp. 128-131.

The Yukon-Tanana region, Alaska; description of the Circle quadrangle, by L. M. Prindle. Bulletin No. 295, 1906, 27 pp.

The Bonnifield and Kantishna regions, by L. M. Prindle. In Bulletin No. 314, 1907, pp. 205-226.

The Circle Precinct, Alaska, by Alfred H. Brooks. In Bulletin No. 314, 1907, pp. 187-204.

The Yukon-Tanana region, Alaska; description of the Fairbanks and Rampart quadrangles, by L. M. Prindle, F. L. Hess, and C. C. Covert. Bulletin No. 337, 1908, $102 \mathrm{pp}$.

Occurrence of gold in the Yukon-Tanana region, by L. M. Prindle. In Bulletin No. 345,1908 , pp. 179-186.

The Fortymile gold placer district, by L. M, Prindle. In Bulletin No. $3 \dot{4} 5,1908$, pp. 187-197.

Water supply of the Fairbanks district in 1907, by C. C. Covert. 'In Bulletin No. 345, 1908, pp. 198-205.

Topographic maps.

Fortymile quadrangle; scale, 1:250000; by E. C. Barnard. For sale at 5 cents a copy or $\$ 3$ per hundred.

Yukon-Tanana region, reconnaissance map of; scale, 1:625000; by T. G. Gerdine. Contained in Bulletin No. 251, 1905. Not published separately.

Fairbanks and Birch Creek districts, reconnaissance maps of ; scale, 1:250000; by T. G. Gerdine. Contained in Bulletin No. 251, 1905. Not issued separately.

Circle quadrangle, Yukon-Tanana region; scale, $1: 250000$; by D. C. Witherspoon: Contained in Bulletin No. 295. Not issued separately.

\section{In preparation.}

Water-supply investigations in Alaska, 1906 and 1907, by F. F. Henshaw and C. C. Covert. Water-Supply Paper No. 218, 1908, 156 pp.

Fairbanks quadrangle map; scale, 1:250000; by D. C. Witherspoon. Contained in Bulletin No. 337, 1908 .

Rampart quadrangle map; scale, 1:250000; by D. C. Witherspoon. Contained in Bulletin No. 337, 1908 .

Fairbanks Special map; scale, 1:62500; by T. G. Gerdine and R. H. Sargent.

\section{SEWARD PENINSULA.}

A reconnaissance of the Cape Nome and adjacent gold fields of Seward Peninsula, Alaska, in 1900, by A. H. Brooks, G. B. Richardson, and A. J. Collier. In a special publication entitled "Reconnaissances in the Cape Nome and Norton Bay regions, Alaska, in 1900," $1901,180 \mathrm{pp}$.

A reconnaissance in the Norton Bay region, Alaska, in 1900 , by W. C. Mendenhall. In a special publication entitled "Reconnaissances in the Cape Nome and Norton Bay regions, Alaska, in 1900."

A reconnaissance of the northwestern portion of Seward Peninsula, Alaska, by A. J. Collier. Professional Paper No. 2, 1902, $70 \mathrm{pp}$.

The tin deposits of the York region, Alaska, by A. J. Collier. Bulletin No. 229, 1904, $61 \mathrm{pp}$.

Recent developments of Alaskan tin deposits, by A. J. Collier. In Bulletin No. 259, 1905 , pp. 120-127.

The Fairhaven gold placers of Seward Peninsula, by F. H. Moffit. Bulletin No. 247, $1905,85 \mathrm{pp}$.

The York tin region, by F. L. Hess. In Bulletin No. 284, 1906, pp. 145-157.

Gold mining on Seward Peninsula, by F、H. Moffit. In Bulletin No. 284, 1906, pp. 132-141.

The Kougarok region, by A. H. Brooks. In Bulletin No. 314, 1907, pp. 164-181. 
Water supply of Nome region, Seward Peninsula, Alaska, 1906, by J. C. "Hoyt and F. F. Henshaw. Water-Supply Paper No. 196, 1907, 52 pp. (Out of stock; can be purchased of Superintendent of Documents for 15 cents.)

Water supply of the Nome region, Seward Peninsula, 1906, by J. C. Hoyt and F. F. Henshaw. In Bulletin No. 314, 1907, pp. 182-186.

The Nome region, by F. H. Moffit. In Bulletin No. 314, 1907, pp. 126-145.

Gold fields of the Solomon and Niukluk river basins, by P. S. Smith. In Bulletin No. 314,1907 , pp. 146-156.

Geology and mineral resources of Iron Creek, by P. S. Smith. In Bulletin No. 314, 1907 , pp. 157-163.

The gold placers of parts of Seward Peninsula, Alaska, including the Nome, Council, Kougarok, Port Clarence, and Goodhope precincts, by A. J. Collier, F. L. Hess, P. S. Smith, and A. H. Brooks. Bulletin No. 328, 1908, 343 pp.

Investigation of the mineral deposits of Seward Peninsula, by P. S. Smith. In Bullećin No. 345, 1908, pp. 206-250.

The Seward Peninsula tin deposits, by Adolph Knopf. In Bulletin No. 345, 1908, pp. 251-267.

Mineral deposits of the Lost River and Brooks Mountain regions, Seward Peninsula, by Adolph Knopf. In Bulletin No. 345, 1908, pp. 268-271.

Water supply of the Nome and Kougarok regions, Seward Peninsula, in 1906-7, by F. F. Henshaw. In Bulletin No. 345, 1908, pp. 272-285.

\section{Topographic maps.}

The following maps are for sale at 5 cents a copy, or $\$ 3$ per hundred:

Casadepaga Quadrangle, Seward Peninsula; scale, 1:62500; by T. G. Gerdine.

Grand Central Special, Seward Peninsula; scale, 1:62500; by T. G. Gerdine.

Nome Special, Seward Peninsula; scale, 1:62500; by T. G. Gerdine.

Solomon Quadrangle, Seward Peninsula; scale, 1:62500; by T. G. Gerdine.

The following maps are for sale at 25 cents a copy, or $\$ 15$ per hundred:

Seward Peninsula, northeastern portion of, topographic reconnaissance of; scale, 1:250000; by T. G. Gerdine.

Seward Peninsula, northwestern portion of, topographic reconnaissance of; scale, 1:250000; by T. G. Gerdine.

Seward Peninsula, southern portion of, topographic reconnaissance of; scale, 1:250000; by T. G. Gerdine.

\section{In preparation.}

Water-supply investigations in Alaska, 1906 and 1907, by F. F. Henshaw and C. C. Covert. Water-Supply Paper No. 218, 1908, $156 \mathrm{pp}$.

Geology of the area represented on the Nome and Grand Central Special maps, by F. H. Moffit, F. L. Hess, and P. S. Smith.

Geology of the area represented on the Solomon and Casadepaga Special maps, by P. S. Smith.

The Seward Peninsula tin deposits, by A. Knopf.

\section{NORTHERN ALASKA.}

A reconnaissance from Fort Hamlin to Kotzebue Sound, Alaska, by way of Dall, Kanuti, Allen, and Kowak rivers, by W. C. Mendenhall. Professional Paper No. $10,1902,68 \mathrm{pp}$.

A reconnaissance in northern Alaska across the Rocky Mountains, along the Koyukuk, John, Anaktuvuk, and Colville rivers, and the Arctic coast to Cape Lisburne, in 1901, by F. C. Schrader and W. J. Peters. Professional Paper No. 20, 1904, 139 pp. (Out of stock; can be purchased of Superintendent of Documents for 40 cents.)

Coal fields of the Cape Lisburne region, by A. J. Collier. In Bulletin No. 259, 1905, pp. $172-185$.

Geology and coal resources of Cape Lisburne region, Alaska, by A. J. Collier. Bulletin No. 278, 1906, $54 \mathrm{pp}$.

\section{Topographic maps.}

Fort Yukon to Kotzebue Sound, reconnaissance map of; scale, 1:1200000; by D. L. Reaburn. Contained in Professional Paper No. 10. Not published separately.

Koyukuk River to mouth of Colville River, including John River; scale, 1:1200000; by W. J. Peters. Contained in Professional Paper No.20. (Out of stock.) Not published separately. 


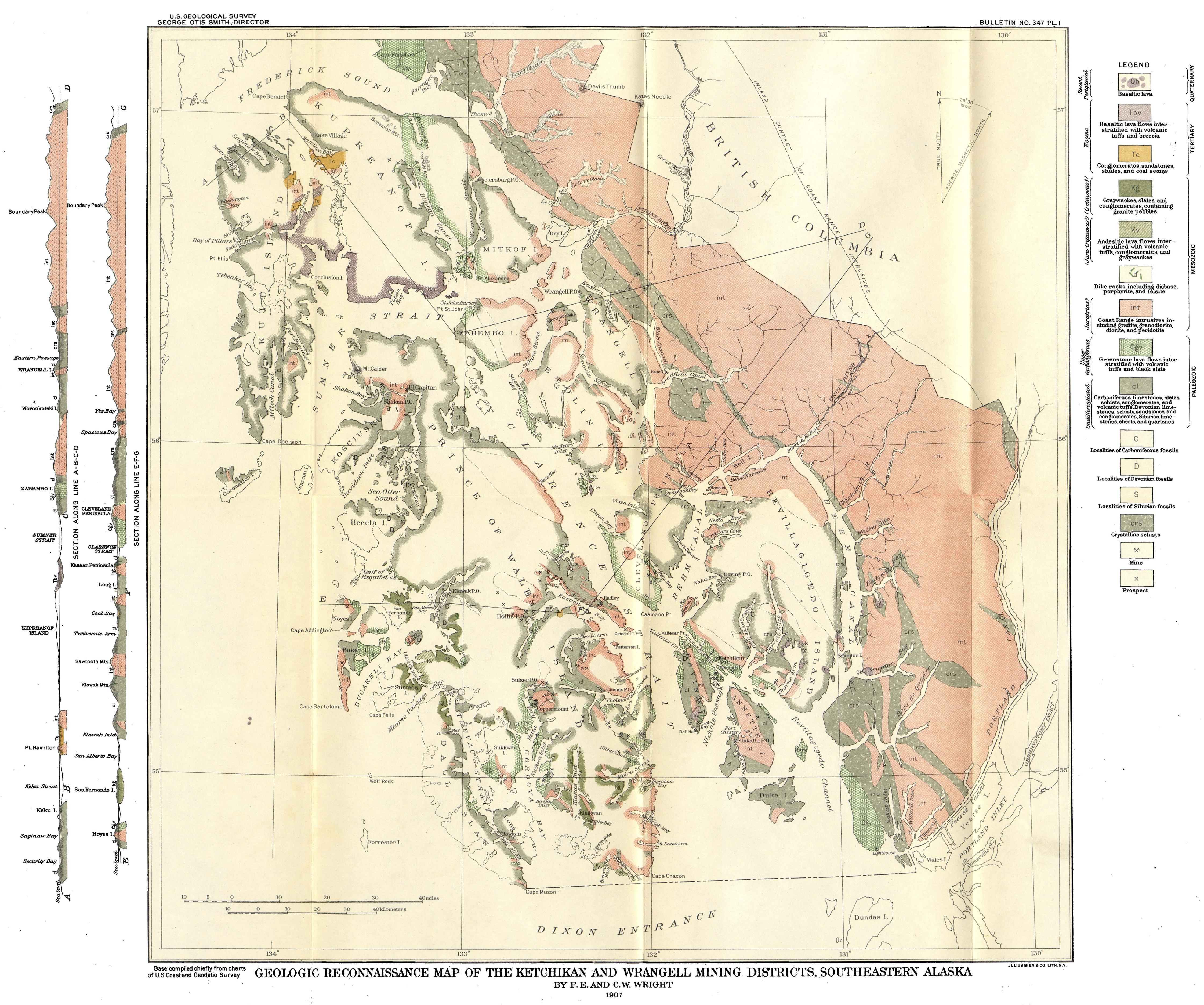






Base compiled chiefly from maps of
International Boundary Commission 
